\title{
ỨNG DỤNG MÔ HİNH BINARY LOGISTIC VÀO PHÂN TÍCH RỦI RO TÍN DỤNG CÁ NHÂN KHÔNG Có TÀI SẢN ĐẢM BẢO TẠI NGÂN HÀNG VPBANK
}

TRANG NGỌC ĐĂNG

19 May 2015

TRUOO'NG ĐAI HOC TȦI CHÍNH-MARKETING

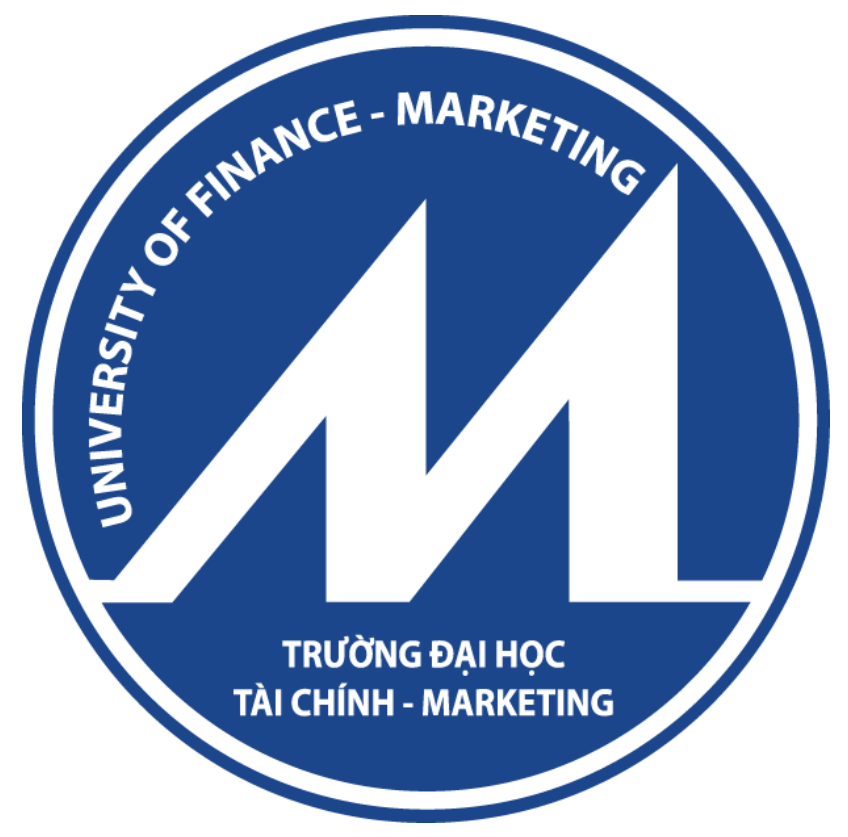

Luận văn Thạc sĩ Kinh tế

Chuyên ngành: Tài chính - Ngân hàng

Mã số: 60.34.02.01 



\title{
Bộ TÀI CHÍNH \\ TRƯờnG ĐẠI HỌC TÀI CHÍNH-MARKETING
}

TRANG NGỌC ĐĂNG

\section{ỨNG DỤNG MÔ HÌNH BINARY LOGISTIC VÀO PHÂN TÍCH RỦI RO TÍN DỤNG CÁ NHÂN KHÔNG CÓ TÀI SẢN ĐẢM BẢO TẠI NGÂN HÀNG VPBANK}

\author{
LUẬN VĂN THẠC SĨ KINH TẾ \\ Chuyên ngành: Tài chính - Ngân hàng \\ Mã số: 60.34.02.01
}

TP. HỒ CHÍ MINH, NĂM 2015 


\title{
Bộ TÀI CHÍNH \\ TRUỜNG ĐẠI HỌC TÀI CHÍNH-MARKETING
}

TRANG NGỌC ĐĂNG

\section{ÚNG DỤNG MÔ HÌNH BINARY LOGISTIC VÀO PHÂN TÍCH RỦI RO TÍN DỤNG CÁ NHÂN KHÔNG CÓ TÀI SẢN ĐẢM BẢO TẠI NGÂN HÀNG VPBANK}

\author{
LUẬN VĂN THẠC SĨ KINH TẾ \\ Chuyên ngành: Tài chính - Ngân hàng \\ Mã số: 60. 34.02.01
}

NGƯỜI HƯỚNG DÃ̃N KHOA HỌC:

TS. NGUYẼ̃N VĂN HIẾN 


\section{LÒ̀I CAM ĐOAN}

Tôi xin cam đoan rằng đây là công trình nghiên cứu của cá nhân tôi, có sự hỗ trợ từ người hướng dẫn khoa học là TS. Nguyễn Văn Hiến. Các nội dung và kết quả nghiên cứu trong luận văn này là chính xác, trung thực và chưa từng được công bố trong bất cứ công trình nào.

Những số liệu được sử dụng cho việc chạy mô hình được chính tác giả thu thập và xử lý, có ghi rõ nguồn gốc.

Ngoài ra trong luận văn có sử dụng một số luận điểm khoa học của các tác giả khác cũng được chú thích nguồn gốc rõ ràng.

Nếu phát hiện bất kỳ sự gian lận nào, tôi xin hoàn toàn chịu trách nhiệm trước pháp luật.

Người cam đoan

Trang Ngọc Đăng 
DANH MỤC CHŨ VIẾT TẮT

\begin{tabular}{|l|l|l|}
\hline Tiếng Việt & Báo cáo tài chính \\
\hline BCTC & Đơn vị tính \\
\hline ĐVT & Ngân hàng nhà nước \\
\hline NHNN & Ngân hàng thương mại \\
\hline NHTM & Thương mại cổ phần \\
\hline TMCP & Rủi ro tín dụng \\
\hline RRTD & Tiếng Anh & Trung tâm thông tin tín dụng \\
\hline CIC & $\begin{array}{l}\text { Credit Information } \\
\text { Center }\end{array}$ & $\begin{array}{l}\text { Ngân hàng thương mại cổ phần Việt Nam Thịnh } \\
\text { Vượng }\end{array}$ \\
\hline VPB & Banks &
\end{tabular}




\section{DANH MỤC BẢNG, HÌNH}

\begin{tabular}{|c|c|c|}
\hline A. BẢNG & Tên Bảng & Trang \\
\hline Bảng 2.1 & Các biến độc lập trong mô hình của Trương Đông Lộc & 16 \\
\hline Bảng 2.2 & Kết quả nghiên cứu của Trương Đông Lộc & 17 \\
\hline Bảng 2.3 & Kết quả nghiên cứu mô hình của Vương Quân Hoàng & 19 \\
\hline Bảng 2.4 & Ký hiệu xếp hạng tín dụng cá nhân theo Stefanie Kleimeier & 21 \\
\hline Bảng 2.5 & Chỉ tiêu xếp hạng tín dụng cá nhân theo Stefanie Kleimeier & 21 \\
\hline Bảng 2.6 & Mô hình xếp hạng của công ty Moody’s và Standard\& Poor's & 28 \\
\hline Bảng 2.7 & $\begin{array}{l}\text { Bảng hạn mức tín dụng theo Mô hình điểm số tín dụng tiêu } \\
\text { dùng }\end{array}$ & 29 \\
\hline Bảng 2.8 & Cấu trúc mô hình đánh giá điểm tín dụng của FICO & 30 \\
\hline Bảng 2.9 & Cấu trúc dữ liệu các biến trong mô hình Logistic & 31 \\
\hline Bảng 3.1 & Số khách hàng được chọn nghiên cứu & 38 \\
\hline Bảng 3.2 & Giá trị của biến phụ thuộc trong mô hình Logistic & 39 \\
\hline Bảng 3.3 & Giá trị các biến độc lập trong mô hình hồi quy Logistic & 40 \\
\hline Bảng 4.1 & Các chỉ tiêu tài chính cơ bản của VPBank & 44 \\
\hline Bảng 4.2 & $\begin{array}{l}\text { Diễn biền lượng hồ sơ vay cá nhân } \\
\text { không có tài sản đảm bảo được duyệt tại VPBank theo quý }\end{array}$ & 52 \\
\hline Bảng 4.3 & Tỷ lệ hồ sơ bị từ chối phân theo lý do & 54 \\
\hline Bảng 4.4 & $\begin{array}{l}\text { Cơ cấu nợ của mảng tín dụng khách hàng cá nhân vay không } \\
\text { có tài sản đảm bảo tại VPBank }\end{array}$ & 56 \\
\hline Bảng 4.5 & Bảng tổng hợp nguyên nhân khách hàng không thanh toán & 57 \\
\hline Bảng 4.6 & Cơ cấu mẫu theo mục đích sử dụng vốn & 59 \\
\hline Bảng 4.7 & Cơ cấu mẫu theo rủi ro tín dụng & 60 \\
\hline Bảng 4.8 & Bảng thống kê mô tả các biến & 61 \\
\hline Bảng 4.9 & Kết quả hồi quy lần 1 với tất cả 18 biến & 62 \\
\hline Bảng 4.10 & Kết quả kiểm định Wald Test để loại bỏ biến X3 & 63 \\
\hline
\end{tabular}




\begin{tabular}{|c|c|c|}
\hline Bảng 4.11 & Kết quả hồi quy lần 2 sau khi bỏ bớt biến X3 & 64 \\
\hline Bảng 4.12 & Kết quả kiểm định Wald Test để loại bỏ biến X4 & 65 \\
\hline Bảng 4.13 & Kết quả hồi quy lần 3 sau khi bỏ bớt biến X3, X4 & 66 \\
\hline Bảng 4.14 & Kết quả kiểm định Wald Test để loại bỏ biến X5 & 67 \\
\hline Bảng 4.15 & Kết quả hồi quy lần 3 sau khi bỏ bớt biến X3, X4, X5 & 68 \\
\hline Bảng 4.16 & Kết quả kiểm định Wald Test để loại bỏ biến X2 & 69 \\
\hline Bảng 4.17 & Kết quả hồi quy lần 5 sau khi bỏ bớt biến X3, X4, X5, X2 & 70 \\
\hline Bảng 4.18 & Kết quả kiểm định Wald Test để loại bỏ biến X15 & 71 \\
\hline Bảng 4.19 & $\begin{array}{l}\text { Kết quả hồi quy lần } 6 \text { sau khi bỏ bớt biến X3, X4, X5, X2, } \\
\text { X15 }\end{array}$ & 72 \\
\hline Bảng 4.20 & Kết quả kiểm định Wald Test để loại bỏ biến X12 & 73 \\
\hline Bảng 4.21 & $\begin{array}{l}\text { Kết quả hồi quy lần } 7 \text { sau khi bỏ bớt biến X3, X4, X5, X2, } \\
\text { X15, X12 }\end{array}$ & 74 \\
\hline Bảng 4.22 & Kết quả kiểm định Wald Test để loại bỏ biến X16 & 75 \\
\hline Bảng 4.23 & $\begin{array}{l}\text { Kết quả hồi quy lần } 8 \text { sau khi bỏ bớt biến X3, X4, X5, X2, } \\
\text { X15, X12, X16 }\end{array}$ & 76 \\
\hline Bảng 4.24 & Kết quả kiểm định Wald Test để loại bỏ biến X6 & 77 \\
\hline Bảng 4.25 & $\begin{array}{l}\text { Kết quả hồi quy lần } 9 \text { sau khi bỏ bớt biến X3, X4, X5, X2, } \\
\text { X15, X12, X16, X6 }\end{array}$ & 78 \\
\hline Bảng 4.26 & Tóm tắt kết quả mô hình nghiên cứu & 79 \\
\hline Bảng 4.27 & $\begin{array}{l}\text { Tác động của từng biến độc lập trong mô hình đến rủi ro tín } \\
\text { dụng }\end{array}$ & 80 \\
\hline Bảng 4.28 & Kết quả tổng quát của mô hình & 81 \\
\hline Bảng 4.29 & Kết quả kiểm đinh Wald Test ý nghĩa các hê số & 82 \\
\hline
\end{tabular}




\begin{tabular}{|l|l|c|}
\hline \multicolumn{1}{|c|}{ B. Hình } & \multicolumn{1}{|c|}{ Tên hình } & Trang \\
\hline Hình 3.1 & Sơ đồ quy trình nghiên cứu & 37 \\
\hline Hình 4.1 & Biểu đồ cơ cấu tín dụng tại VPBank & 47 \\
\hline Hình 4.2 & $\begin{array}{l}\text { Diễn biến lượng hồ sơ vay cá nhân không có tài sản đảm bảo } \\
\text { tại VPBank theo Quý }\end{array}$ & 51 \\
\hline Hình 4.3 & $\begin{array}{l}\text { Biểu đồ diễn biền lượng hồ sơ vay cá nhân không có tài sản } \\
\text { đảm bảo được duyệt tại VPBank theo quý }\end{array}$ & 53 \\
\hline Hình 4.4 & $\begin{array}{l}\text { Biều đồ diễn biến tỷ lệ khách hàng bị từ chối tín dụng theo lý } \\
\text { do }\end{array}$ & 55 \\
\hline Hình 4.5 & Biểu đồ tỷ lệ nợ xấu tại VPBank năm 2012-2014 & 55 \\
\hline Hình 4.6 & $\begin{array}{l}\text { Biểu đồ cơ cấu nhóm nợ của mảng tín dụng khách hàng cá } \\
\text { nhân vay không có tài sản đảm bảo tại VPBank }\end{array}$ & 56 \\
\hline
\end{tabular}




\section{MỤC LỤC}

CHƯƠNG 1 TỔNG QUAN ĐỀ TÀI NGHIÊN CÚU 1

1.1 Tính cấp thiết của đề tài ............................................................. 1

1.2 Tình hình nghiên cứu đề tài ................................................. 2

1.3 Mục tiêu và câu hỏi nghiên cứu của đề tài ............................................................... 4

1.3.1 Mục tiêu nghiên cứu .....................................................................................

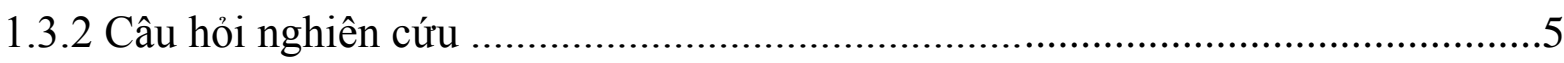

1.4 Đối tượng và phạm vi nghiên cứu ..............................................5

1.4.1 Đối tượng nghiên cứu .......................................................... 5

1.4.2 Phạm vi nghiên cứu ..................................................... 5

1.5 Phương pháp nghiên cứu ..................................................... 5

1.6 Ý nghĩa khoa học và thực tiễn của đề tài ...................................6

1.6.1 Ý nghĩa khoa học ..........................................................6

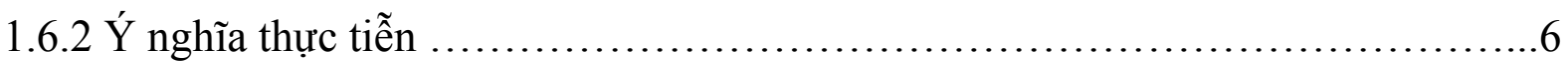

1.7 Bố cục của nghiên cứu ......................................................... 7

CHƯONG 2 CƠ SỞ LÝ THUYÊT VÀ MÔ HÌNH NGHIÊN CÚU .........................8

2.1 Cơ sở lý thuyết ......................................................................................................8

2.1.1 Tổng quan về tín dụng khách hàng cá nhân ..................................8

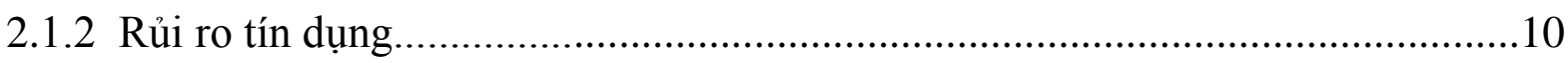

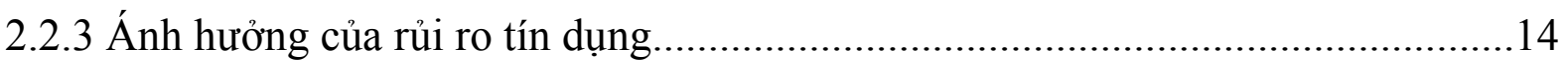

2.2 Giới thiệu một số nghiên cứu trước đây về đo lường các yếu tố ảnh hưởng đến rủi ro tín dụng ................................................................. 16

2.3 Mô hình đo lường rủi ro tín dụng............................................. 22

2.3.1 Giới thiệu một số mô hình đo lường rủi ro tín dụng..............................22

2.3.2 Giới thiệu mô hình hồi quy Logistic ........................................... 30

2.3.3 Phân tích cơ sở lựa chọn mô hình hồi quy Binary Logisttic để phân tích rủi ro tín dụng khách hàng cá nhân không có tài sản đảm bảo tại VPBank 


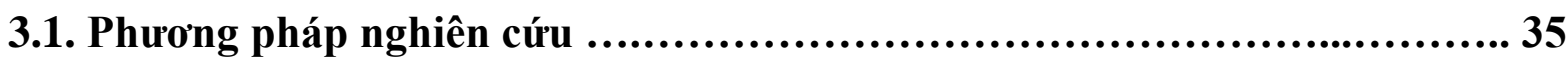

3.2 Quy trình nghiên cứu.......................................................... 36

3.3 Lấy mẫu nghiên cứu ......................................................37

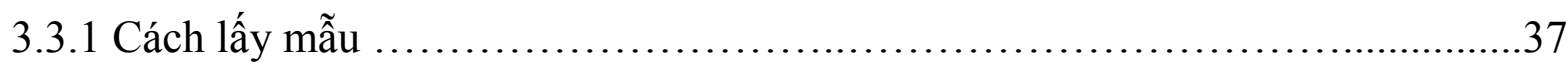

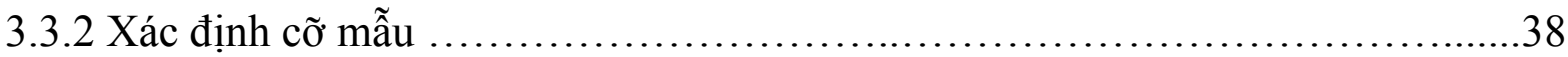

3.4 Biện luận mô hình nghiên cứu ...................................................39

3.4.1 Xác định các biến phụ thuộc .....................................................40

3.4.2 Xác định các biến độc lập .......................................................40

3.4.3 Biện luận mô hình nghiên cứu ..........................................41

CHƯỚ 4 KẾT QUẢ NGHIÊN CÚU VÀ THẢO LUẬN ..................................44

4.1 Giới thiệu chung về VPBank .......................................................................44

4.1.1 Lĩnh vực hoạt động .....................................................45

4.1.2 Cơ cấu tín dụng tại VPBank .................................................47

4.1.3 Các sản phẩm cho vay khách hàng cá nhân ................................48

4.2 Thực trạng quản lý rủi ro tín dụng tại cá nhân không có tài sản đảm bảo tại VPBank ........................................................................48

4.2.1 Quy trình quản lý rủi ro tại khâu thẩm định..................................48

4.2.2 Quy trình quản lý rủi ro tại khâu giám sát sau cho vay và thu hồi nợ ...........50

4.2.3 Phân tích rủi ro tín dụng khách hàng cá nhân không có tài sản đảm bảo tại

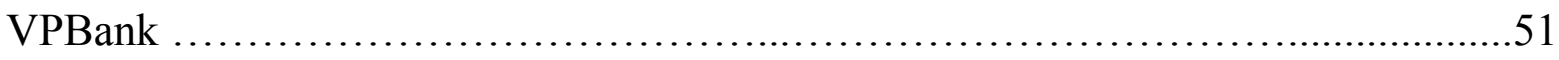

4.2.4 Nhận định về quy trình quản lý rủi ro tín dụng khách hàng cá nhân vay không có tài sản đảm bảo tại VPBank .................................................... 58

4.3 Kết quả nghiên cứu ..........................................................5 59

4.3.1 Kết quả thống kê mẫu nghiên cứu ............................................ 59

4.3.2 Kiểm định tự tương quan............................................. 61

4.3.3 Quy trình xây dựng mô hình tối ưu ............................................ 62

4.3.4 Kết quả nghiên cứu đưa ra mô hình Binary Logistic ........................................79

4.4 Kiểm định thống kê .............................................................. 81

4.4.1 Kiểm định độ phù hợp của mô hình ...........................................81

4.4.2 Kiểm định ý nghĩa thống kê các hệ số ............................................81 
4.5 Thảo luận về các biến nghiên cứu theo kết quả đối chiếu với thực tế..........83 CHƯƠNG 5 KẾT LUẬN VÀ GỢI Ý GIẢI PHÁP ..................................87

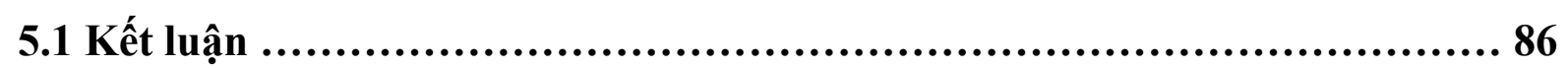

5.2 Gọi ý giải pháp ................................................................ 87

5.2.1 Gợi ý chính sách chung ............................................ 88

5.2.2 Gợi ý áp dụng Mô hình logistic trong việc xác định xác suất rủi ro tín dụng khách hàng cá nhân vay tiền mặt tại VPBank ................................. 93

5.3 Những hạn chế của đề tài và hướng nghiên cứu tiếp theo ....................94 


\section{PHỤ LỤC 01: CƠ CẤU MẪU NGHIÊN CỨU CỦA TRƯƠNG ĐÔNG LộC}

\begin{tabular}{|c|c|c|}
\hline Tiêu chí phân loại & Số mẫu & Tỷ lệ (\%) \\
\hline \multicolumn{3}{|c|}{ Theo loại hình doanh nghiệp } \\
\hline DNNN & 4 & 0.9 \\
\hline Cty TNHH và CTCP & 70 & 16 \\
\hline DNTN & 66 & 15.1 \\
\hline Cá nhân & 298 & 68 \\
\hline Tổng & 438 & 100 \\
\hline \multicolumn{3}{|l|}{ Theo ngành kinh tế } \\
\hline $\begin{array}{l}\text { Nông nghiệp - Lâm } \\
\text { nghiệp }\end{array}$ & 35 & 8 \\
\hline Thuỷ sản & 28 & 6.4 \\
\hline Xây dựng & 49 & 11.2 \\
\hline $\begin{array}{l}\text { Thương nghiệp, dịch } \\
\text { vụ }\end{array}$ & 136 & 31 \\
\hline Ngành khác & 190 & 43.4 \\
\hline Tổng & 438 & 100 \\
\hline \multicolumn{3}{|l|}{ Theo thò̀i hạn vay } \\
\hline Ngắn hạn & 245 & 56 \\
\hline Trung hạn & 146 & 33.3 \\
\hline Dài hạn & 47 & 10.7 \\
\hline Tổng & 438 & 100 \\
\hline
\end{tabular}


PHỤ LỤC 02: MÔ HÌNH ĐIỂM SỐ TÍN DỤNG TIÊU DÙNG

\begin{tabular}{|c|c|c|}
\hline STT & Các hạng mục xác định chất lượng tín dụng & Điểm \\
\hline \multirow{7}{*}{1} & Nghề nghiệp của người vay (Max: 10đ) & \\
\hline & _ Chuyên gia hay phụ trách kinh doanh & 10 \\
\hline & Công nhân có kinh nghiệm & 8 \\
\hline & _ Nhân viên văn phòng & 7 \\
\hline & _ Sinh viên & 5 \\
\hline & __ông nhân không có kinh nghiệm & 4 \\
\hline & Công nhân bán thất nghiệp & 2 \\
\hline \multirow{4}{*}{2} & Trạng thái nhà ở (Max: 6đ) & \\
\hline & _ Nhà riêng & 6 \\
\hline & _ Nhà thuê hay căn hộ & 4 \\
\hline & _ Sống cùng bạn hay người thân & 2 \\
\hline \multirow{5}{*}{3} & Xếp hạng tín dụng (Max: 10đ) & \\
\hline & _ Tốt & 10 \\
\hline & _ Trung bình & 5 \\
\hline & Không có hồ sơ & 2 \\
\hline & _ Tồi & 0 \\
\hline \multirow{3}{*}{4} & Kinh nghiệm nghề nghiệp (Max: 5đ) & \\
\hline & _Nhiều hơn 1 năm & 5 \\
\hline & _ Từ 1 năm trở xuống & 2 \\
\hline \multirow{3}{*}{5} & Thời gian sống tại địa chỉ hiện hành (Max: 2đ) & \\
\hline & _ Nhiều hơn 1 năm & 2 \\
\hline & _ Từ 1 năm trở xuống & 1 \\
\hline \multirow{3}{*}{6} & Điện thoại cố định (max: 2đ) & \\
\hline & _Có & 2 \\
\hline & _ Không có & 0 \\
\hline \multirow{3}{*}{7} & Số người sống cùng (Phụ thuộc) (Max: 4đ) & \\
\hline & -0 & 3 \\
\hline & -1 & 3 \\
\hline
\end{tabular}




\begin{tabular}{|c|c|c|}
\hline & -2 & 4 \\
\hline & -3 & 4 \\
\hline & _ Nhiều hơn 3 & 2 \\
\hline \multirow{5}{*}{8} & Các tài khoản tại ngân hàng (Max: 4đ) & \\
\hline & _ Các tài khoản tiết kiệm và phát hành $\mathrm{Sec}$ & 4 \\
\hline & _Chỉ tài khoản tiết kiệm & 3 \\
\hline & _ Chỉ tài khoản phát hành Sec & 2 \\
\hline & _ Không có & 0 \\
\hline
\end{tabular}


PHUU LỰC 03: BẢNG MÔ TẢ CÁC SẢN PHẨM CHO VAY KHÁCH HÀNG CÁ NHẦN KHÔNG CÓ TÀI SẢN ĐÃM BẢO TẠI VPBANK

\begin{tabular}{|c|c|c|c|c|c|}
\hline \multirow{2}{*}{ Sản phẩm } & \multicolumn{2}{|l|}{ Khoản vay } & \multicolumn{2}{|c|}{$\begin{array}{l}\text { Thò̀i hạn vay } \\
\text { (tháng) }\end{array}$} & \multirow{2}{*}{$\begin{array}{l}\text { Lãi suất } \\
\text { trung bình } \\
1 \text { tháng }\end{array}$} \\
\hline & Tối thiểu & Tối đa & $\begin{array}{l}\text { Tối } \\
\text { thiểu }\end{array}$ & Tối đa & \\
\hline $\begin{array}{l}\text { Sản phẩm dành cho } \\
\text { khách hàng hưởng lương } \\
\text { cao cấp }\end{array}$ & $10,000,000$ & $200,000,000$ & 12 & 48 & $1.50 \%$ \\
\hline $\begin{array}{l}\text { Sản phẩm dành cho } \\
\text { khách hàng hưởng lương, } \\
\text { thu nhập cao }\end{array}$ & $10,000,000$ & $200,000,000$ & 6 & 36 & $2.50 \%$ \\
\hline $\begin{array}{l}\text { Sản phẩm dành cho } \\
\text { khách hàng hưởng lương, } \\
\text { làm việc tại công ty lớn } \\
\text { và vừa có thu nhập từ } \\
\text { trung bình đến cao }\end{array}$ & $10,000,000$ & $100,000,000$ & 6 & 36 & $2.92 \%$ \\
\hline $\begin{array}{l}\text { Sản phẩm dành cho } \\
\text { khách hàng hưởng lương, } \\
\text { làm việc tại tất cả công ty } \\
\text { có thu nhập từ trung bình } \\
\text { đến cao }\end{array}$ & $10,000,000$ & $100,000,000$ & 6 & 36 & $3.75 \%$ \\
\hline $\begin{array}{l}\text { Sản phẩm dành cho } \\
\text { khách hàng hưởng lương, } \\
\text { thu nhập trung bình }\end{array}$ & $10,000,000$ & $30,000,000$ & 6 & 24 & $5.00 \%$ \\
\hline $\begin{array}{l}\text { Sản phẩm dành cho } \\
\text { khách hàng tự doanh thu } \\
\text { nhập cao }\end{array}$ & $10,000,000$ & $200,000,000$ & 6 & 36 & $2.92 \%$ \\
\hline $\begin{array}{l}\text { Sản phẩm dành cho } \\
\text { khách hàng tự doanh thu }\end{array}$ & $10,000,000$ & $100,000,000$ & 6 & 36 & $5.00 \%$ \\
\hline
\end{tabular}




\begin{tabular}{|c|c|c|c|c|c|}
\hline nhập trung bình & & & & & \\
\hline $\begin{array}{l}\text { Sản phẩm dành cho } \\
\text { khách hàng có khoản vay } \\
\text { ở tổ chức tín dụng khác }\end{array}$ & $10,000,000$ & $100,000,000$ & 6 & 36 & $4.58 \%$ \\
\hline $\begin{array}{l}\text { Sản phẩm dành cho } \\
\text { khách hàng có bảo hiểm } \\
\text { nhân thọ }\end{array}$ & $10,000,000$ & $100,000,000$ & 6 & 36 & $2.92 \%$ \\
\hline $\begin{array}{l}\text { Sản phẩm dành cho } \\
\text { khách hàng đã vay tại } \\
\text { VPBank }\end{array}$ & $10,000,000$ & $100,000,000$ & 6 & 36 & $4.58 \%$ \\
\hline $\begin{array}{l}\text { Sản phẩm dành cho } \\
\text { khách hàng có hóa đơn } \\
\text { tiền điện giá trị lớn }\end{array}$ & $15,000,000$ & $30,000,000$ & 6 & 36 & $2.92 \%$ \\
\hline $\begin{array}{l}\text { Sản phẩm dành cho } \\
\text { khách hàng có hóa đơn } \\
\text { tiền điện giá trị nhỏ }\end{array}$ & $20,000,000$ & $60,000,000$ & 6 & 36 & $3.75 \%$ \\
\hline $\begin{array}{l}\text { Sản phẩm khuyến mãi } \\
\text { dành cho khách hàng có } \\
\text { hóa đơn internet FPT giá } \\
\text { trị lớn và chứng minh thu } \\
\text { nhập }\end{array}$ & $10,000,000$ & $100,000,000$ & 6 & 36 & $2.92 \%$ \\
\hline $\begin{array}{l}\text { Sản phẩm khuyến mãi } \\
\text { dành cho khách hàng có } \\
\text { hóa đơn internet FPT giá } \\
\text { trị nhỏ và chứng minh thu } \\
\text { nhập }\end{array}$ & $10,000,000$ & $100,000,000$ & 6 & 36 & $3.75 \%$ \\
\hline $\begin{array}{l}\text { Sản phẩm khuyến mãi } \\
\text { dành cho khách hàng có } \\
\text { hóa đơn internet FPT giá } \\
\text { trị lớn và không cần }\end{array}$ & $6,000,000$ & $20,000,000$ & 6 & 24 & $3.33 \%$ \\
\hline
\end{tabular}




\begin{tabular}{|c|c|c|c|c|c|}
\hline chứng minh thu nhập & & & & & \\
\hline $\begin{array}{l}\text { Sản phẩm khuyến mãi } \\
\text { dành cho khách hàng có } \\
\text { hóa đơn internet FPT giá } \\
\text { trị nhỏ và không cần } \\
\text { chứng minh thu nhập }\end{array}$ & $6,000,000$ & $15,000,000$ & 6 & 24 & $4.17 \%$ \\
\hline
\end{tabular}




\section{PHỤ LỤC 04: QUY TRÌnH CHỌN LỰA MÔ HÌNH TỐI ƯU}

\subsection{Hồi quy lần 1}

Dependent Variable: $\mathrm{Y}$

Method: ML - Binary Logit (Quadratic hill climbing)

Date: 07/16/15 Time: $16: 12$

\begin{tabular}{|c|c|c|c|c|}
\hline Variable & Coefficient & Std. Error & z-Statistic & Prob. \\
\hline $\mathrm{C}$ & 1.838225 & 5.744948 & 0.319972 & 0.749 \\
\hline $\mathrm{X} 2$ & $1.90 \mathrm{E}-07$ & $3.30 \mathrm{E}-07$ & 0.575077 & 0.5652 \\
\hline $\mathrm{X} 3$ & -0.089497 & 0.24746 & -0.36166 & 0.7176 \\
\hline $\mathrm{X} 4$ & 68.16965 & 125.8862 & 0.541518 & 0.5882 \\
\hline $\mathrm{X} 5$ & $-2.45 \mathrm{E}-06$ & $4.88 \mathrm{E}-06$ & -0.50251 & 0.6153 \\
\hline $\mathrm{X} 6$ & -1.999097 & 1.799271 & -1.111059 & 0.2665 \\
\hline $\mathrm{X} 7$ & -4.450593 & 1.356286 & -3.281456 & 0.001 \\
\hline $\mathrm{X} 8$ & -3.052782 & 1.232248 & -2.477409 & 0.0132 \\
\hline $\mathrm{X} 9$ & 0.156806 & 0.073214 & 2.14174 & 0.0322 \\
\hline $\mathrm{X} 10$ & -4.107719 & 1.495883 & -2.746015 & 0.006 \\
\hline $\mathrm{X} 11$ & -2.338248 & 1.352319 & -1.729066 & 0.0838 \\
\hline $\mathrm{X} 12$ & -0.11474 & 0.121219 & -0.946556 & 0.3439 \\
\hline $\mathrm{X} 13$ & 1.085612 & 0.504391 & 2.152324 & 0.0314 \\
\hline $\mathrm{X} 14$ & -0.485022 & 0.262354 & -1.848729 & 0.0645 \\
\hline $\mathrm{X} 15$ & -0.4432 & 0.426181 & -1.039934 & 0.2984 \\
\hline $\mathrm{X} 16$ & 0.720568 & 0.805405 & 0.894665 & 0.371 \\
\hline $\mathrm{X} 17$ & -3.514451 & 1.380175 & -2.546381 & 0.0109 \\
\hline $\mathrm{X} 18$ & -0.93091 & 0.341943 & -2.722414 & 0.0065 \\
\hline X19 & 1.32727 & 0.507496 & 2.615332 & 0.0089 \\
\hline McFadden R-squared & 0.720082 & \multicolumn{2}{|l|}{ Mean dependent var } & 0.111111 \\
\hline S.D. dependent var & 0.315032 & \multicolumn{2}{|l|}{ S.E. of regression } & 0.167542 \\
\hline Akaike info criterion & 0.378863 & \multicolumn{2}{|l|}{ Sum squared resid } & 5.277217 \\
\hline Schwarz criterion & 0.684765 & \multicolumn{2}{|l|}{ Log likelihood } & -20.2124 \\
\hline Hannan-Quinn criter. & 0.502567 & \multicolumn{2}{|l|}{ Deviance } & 40.42472 \\
\hline Restr. deviance & 144.4165 & \multicolumn{2}{|l|}{ Restr. log likelihood } & -72.2082 \\
\hline LR statistic & 103.9918 & \multirow{2}{*}{\multicolumn{2}{|c|}{ Avg. log likelihood }} & -0.09764 \\
\hline Prob(LR statistic) & 0 & & & \\
\hline
\end{tabular}




\subsection{Hồi quy lần 2}

Dependent Variable: Y

Method: ML - Binary Logit (Quadratic hill climbing)

Date: 07/16/15 Time: 16:20

\begin{tabular}{|c|c|c|c|c|}
\hline Variable & Coefficient & Std. Error & z-Statistic & Prob. \\
\hline $\mathrm{C}$ & 0.506531 & 4.378343 & 0.11569 & 0.9079 \\
\hline $\mathrm{X} 2$ & 7.89E-08 & $1.18 \mathrm{E}-07$ & 0.669926 & 0.5029 \\
\hline $\mathrm{X} 4$ & 49.77611 & 113.6086 & 0.438137 & 0.6613 \\
\hline $\mathrm{X} 5$ & $-8.35 \mathrm{E}-07$ & $1.87 \mathrm{E}-06$ & -0.445934 & 0.6556 \\
\hline X6 & -2.079551 & 1.784302 & -1.16547 & 0.2438 \\
\hline $\mathrm{X} 7$ & -4.471621 & 1.367747 & -3.269332 & 0.0011 \\
\hline $\mathrm{X} 8$ & -3.016485 & 1.217672 & -2.477255 & 0.0132 \\
\hline $\mathrm{X} 9$ & 0.154399 & 0.07322 & 2.108686 & 0.035 \\
\hline $\mathrm{X} 10$ & -4.010789 & 1.447644 & -2.770563 & 0.0056 \\
\hline $\mathrm{X} 11$ & -2.44103 & 1.32356 & -1.84429 & 0.0651 \\
\hline $\mathrm{X} 12$ & -0.104677 & 0.118945 & -0.880041 & 0.3788 \\
\hline $\mathrm{X} 13$ & 1.119025 & 0.493357 & 2.268184 & 0.0233 \\
\hline $\mathrm{X} 14$ & -0.503948 & 0.268229 & -1.878794 & 0.0603 \\
\hline $\mathrm{X} 15$ & -0.41259 & 0.420568 & -0.981031 & 0.3266 \\
\hline $\mathrm{X} 16$ & 0.729541 & 0.827525 & 0.881594 & 0.378 \\
\hline $\mathrm{X} 17$ & -3.493309 & 1.400832 & -2.493738 & 0.0126 \\
\hline $\mathrm{X} 18$ & -0.948988 & 0.349706 & -2.713671 & 0.0067 \\
\hline $\mathrm{X} 19$ & 1.322097 & 0.511042 & 2.587059 & 0.0097 \\
\hline McFadden R-squared & 0.719168 & \multicolumn{2}{|l|}{ Mean dependent var } & 0.111111 \\
\hline S.D. dependent var & 0.315032 & \multicolumn{2}{|l|}{ S.E. of regression } & 0.166752 \\
\hline Akaike info criterion & 0.36984 & \multicolumn{2}{|l|}{ Sum squared resid } & 5.255372 \\
\hline Schwarz criterion & 0.659641 & \multicolumn{2}{|l|}{ Log likelihood } & -20.2784 \\
\hline Hannan-Quinn criter. & 0.487033 & \multicolumn{2}{|l|}{ Deviance } & 40.55679 \\
\hline Restr. deviance & 144.4165 & \multicolumn{2}{|l|}{ Restr. log likelihood } & -72.2082 \\
\hline LR statistic & 103.8597 & \multicolumn{2}{|l|}{ Avg. log likelihood } & -0.09796 \\
\hline Prob(LR statistic) & 0 & & & \\
\hline
\end{tabular}




\subsection{Hồi quy lần 3}

Dependent Variable: Y

Method: ML - Binary Logit (Quadratic hill climbing)

Date: 07/16/15 Time: 16:16

\begin{tabular}{|c|c|c|c|c|}
\hline Variable & Coefficient & Std. Error & z-Statistic & Prob. \\
\hline $\mathrm{C}$ & 1.889197 & 3.059036 & 0.6176 & 0.5369 \\
\hline $\mathrm{X} 2$ & $5.83 \mathrm{E}-08$ & $1.07 \mathrm{E}-07$ & 0.5439 & 0.5865 \\
\hline$X 5$ & $-3.69 E-07$ & $1.54 \mathrm{E}-06$ & -0.2398 & 0.8105 \\
\hline X6 & -2.333344 & 1.750536 & -1.3329 & 0.1826 \\
\hline $\mathrm{X} 7$ & -4.572943 & 1.369238 & -3.3398 & 0.0008 \\
\hline $\mathrm{X} 8$ & -3.058272 & 1.228766 & -2.4889 & 0.0128 \\
\hline $\mathrm{X9}$ & 0.163738 & 0.070847 & 2.3112 & 0.0208 \\
\hline $\mathrm{X} 10$ & -3.937472 & 1.422916 & -2.7672 & 0.0057 \\
\hline X11 & -2.510686 & 1.331589 & -1.8855 & 0.0594 \\
\hline $\mathrm{X} 12$ & -0.104852 & 0.121909 & -0.8601 & 0.3897 \\
\hline X13 & 1.110472 & 0.487059 & 2.28 & 0.0226 \\
\hline X14 & -0.512302 & 0.272803 & -1.8779 & 0.0604 \\
\hline X15 & -0.414988 & 0.426392 & -0.9733 & 0.3304 \\
\hline X16 & 0.685338 & 0.811762 & 0.8443 & 0.3985 \\
\hline $\mathrm{X} 17$ & -3.247297 & 1.248225 & -2.6015 & 0.0093 \\
\hline $\mathrm{X} 18$ & -0.93926 & 0.340173 & -2.7611 & 0.0058 \\
\hline X19 & 1.332527 & 0.504883 & 2.6393 & 0.0083 \\
\hline McFadden R-squared & 0.719199 & \multicolumn{2}{|l|}{ Mean dependent var } & 0.1095 \\
\hline S.D. dependent var & 0.313042 & \multicolumn{2}{|l|}{ S.E. of regression } & 0.1649 \\
\hline Akaike info criterion & 0.355949 & \multicolumn{2}{|l|}{ Sum squared resid } & 5.2488 \\
\hline Schwarz criterion & 0.626905 & \multicolumn{2}{|l|}{ Log likelihood } & 20.375 \\
\hline Hannan-Quinn criter. & 0.465487 & \multicolumn{2}{|l|}{ Deviance } & 40.749 \\
\hline Restr. deviance & 145.1178 & \multicolumn{2}{|l|}{ Restr. log likelihood } & $\begin{array}{r}- \\
72.559\end{array}$ \\
\hline LR statistic & 104.3685 & \multicolumn{2}{|l|}{ Avg. log likelihood } & -0.097 \\
\hline Prob(LR statistic) & 0 & & & \\
\hline
\end{tabular}




\subsection{Hồi quy lần 4}

Dependent Variable: Y

Method: ML - Binary Logit (Quadratic hill climbing)

Date: 07/16/15 Time: 16:23

\begin{tabular}{|c|c|c|c|c|}
\hline Variable & Coefficient & Std. Error & z-Statistic & Prob. \\
\hline $\mathrm{C}$ & 1.508858 & 2.593969 & 0.581679 & 0.5608 \\
\hline $\mathrm{X} 2$ & $4.86 \mathrm{E}-08$ & $9.96 \mathrm{E}-08$ & 0.488431 & 0.6252 \\
\hline X6 & -2.322468 & 1.769114 & -1.312786 & 0.1893 \\
\hline $\mathrm{X} 7$ & -4.577138 & 1.366166 & -3.350354 & 0.0008 \\
\hline $\mathrm{X} 8$ & -2.98868 & 1.193059 & -2.505055 & 0.0122 \\
\hline $\mathrm{X9}$ & 0.16387 & 0.069668 & 2.352169 & 0.0187 \\
\hline $\mathrm{X} 10$ & -3.902522 & 1.402134 & -2.783273 & 0.0054 \\
\hline $\mathrm{X} 11$ & -2.484759 & 1.301168 & -1.909637 & 0.0562 \\
\hline $\mathrm{X} 12$ & -0.099517 & 0.11717 & -0.849336 & 0.3957 \\
\hline $\mathrm{X} 13$ & 1.112169 & 0.485185 & 2.292258 & 0.0219 \\
\hline $\mathrm{X} 14$ & -0.504796 & 0.264134 & -1.911135 & 0.056 \\
\hline $\mathrm{X} 15$ & -0.44669 & 0.414542 & -1.077551 & 0.2812 \\
\hline $\mathrm{X} 16$ & 0.702481 & 0.805761 & 0.871823 & 0.3833 \\
\hline $\mathrm{X} 17$ & -3.214572 & 1.242638 & -2.586894 & 0.0097 \\
\hline $\mathrm{X} 18$ & -0.951555 & 0.336523 & -2.82761 & 0.0047 \\
\hline X19 & 1.354712 & 0.500197 & 2.708359 & 0.0068 \\
\hline McFadden R-squared & 0.718795 & \multicolumn{2}{|c|}{ Mean dependent var } & 0.109524 \\
\hline S.D. dependent var & 0.313042 & \multicolumn{2}{|l|}{ S.E. of regression } & 0.163777 \\
\hline Akaike info criterion & 0.346704 & \multicolumn{2}{|l|}{ Sum squared resid } & 5.203651 \\
\hline Schwarz criterion & 0.601722 & \multicolumn{2}{|l|}{ Log likelihood } & -20.40393 \\
\hline Hannan-Quinn criter. & 0.449798 & \multicolumn{2}{|l|}{ Deviance } & 40.80786 \\
\hline Restr. deviance & 145.1178 & \multicolumn{2}{|c|}{ Restr. log likelihood } & -72.5589 \\
\hline LR statistic & 104.3099 & \multicolumn{2}{|c|}{ Avg. log likelihood } & -0.097162 \\
\hline Prob(LR statistic) & 0 & & & \\
\hline
\end{tabular}




\subsection{Hồi quy lần 5}

Dependent Variable: $\mathrm{Y}$

Method: ML - Binary Logit (Quadratic hill climbing)

Date: 07/16/15 Time: 16:26

\begin{tabular}{|c|r|r|r|r|}
\hline Variable & Coefficient & Std. Error & z-Statistic & \multicolumn{1}{c|}{ Prob. } \\
\hline C & 2.011678 & 2.377115 & 0.846269 & 0.3974 \\
\hline X6 & -2.265967 & 1.774389 & -1.27704 & 0.2016 \\
\hline X8 & -4.405547 & 1.28596 & -3.425881 & 0.0006 \\
\hline X9 & -2.978297 & 1.19415 & -2.494072 & 0.0126 \\
\hline X10 & 0.163238 & 0.068922 & 2.368458 & 0.0179 \\
\hline X11 & -3.843514 & 1.378435 & -2.788317 & 0.0053 \\
\hline X12 & -2.330855 & 1.251667 & -1.8622 & 0.0626 \\
\hline X13 & -0.119782 & 0.109447 & -1.094437 & 0.2738 \\
\hline X14 & 1.128638 & 0.480897 & 2.346942 & 0.0189 \\
\hline X15 & -0.554615 & 0.260244 & -2.131131 & 0.0331 \\
\hline X16 & -0.398669 & 0.391382 & -1.018619 & 0.3084 \\
\hline X17 & 0.938856 & 0.672949 & 1.395137 & 0.163 \\
\hline X18 & -3.314855 & 1.241341 & -2.670382 & 0.0076 \\
\hline X19 & -1.003074 & 0.339068 & -2.958332 & 0.0031 \\
\hline 1.401279 & 0.501561 & 2.793837 & 0.0052 \\
\hline McFadden R-squared & 0.717184 & Mean dependent var & 0.109524 \\
\hline S.D. dependent var & 0.313042 & S.E. of regression & 0.166115 \\
\hline Akaike info criterion & 0.338293 & Sum squared resid & 5.380855 \\
\hline Schwarz criterion & 0.577372 & Log likelihood & -20.52079 \\
\hline Hannan-Quinn criter. & 0.434944 & \multicolumn{2}{|c|}{ Deviance } & 41.04158 \\
\hline Restr. deviance & 145.1178 & Restr. log likelihood & -72.5589 \\
\hline LR statistic & 104.0762 & Avg. log likelihood & -0.097718 \\
\hline Prob(LR statistic) & 0 & \multicolumn{4}{|l|}{} \\
\hline
\end{tabular}




\subsection{Hồi quy lần 6}

Dependent Variable: Y

Method: ML - Binary Logit (Quadratic hill climbing)

Date: 07/16/15 Time: 16:30

\begin{tabular}{|c|c|c|c|c|}
\hline Variable & Coefficient & Std. Error & z-Statistic & Prob. \\
\hline $\mathrm{C}$ & 1.82966 & 2.254367 & 0.811607 & 0.417 \\
\hline X6 & -2.638067 & 1.931544 & -1.365781 & 0.172 \\
\hline $\mathrm{X7}$ & -4.387364 & 1.277379 & -3.434661 & 0.0006 \\
\hline $\mathrm{X} 8$ & -2.72846 & 1.124158 & -2.427115 & 0.0152 \\
\hline $\mathrm{X} 9$ & 0.145585 & 0.063131 & 2.306064 & 0.0211 \\
\hline $\mathrm{X} 10$ & -3.542718 & 1.274234 & -2.780272 & 0.0054 \\
\hline $\mathrm{X} 11$ & -2.533355 & 1.279281 & -1.980295 & 0.0477 \\
\hline $\mathrm{X} 12$ & -0.104804 & 0.109799 & -0.954502 & 0.3398 \\
\hline $\mathrm{X} 13$ & 1.147696 & 0.484558 & 2.36854 & 0.0179 \\
\hline $\mathrm{X} 14$ & -0.58686 & 0.274954 & -2.134394 & 0.0328 \\
\hline $\mathrm{X} 16$ & 0.4038 & 0.388428 & 1.039577 & 0.2985 \\
\hline $\mathrm{X} 17$ & -3.272972 & 1.170712 & -2.79571 & 0.0052 \\
\hline $\mathrm{X} 18$ & -0.979147 & 0.330198 & -2.965333 & 0.003 \\
\hline $\mathrm{X} 19$ & 1.328388 & 0.477721 & 2.780676 & 0.0054 \\
\hline McFadden R-squared & 0.709645 & \multicolumn{2}{|c|}{ Mean dependent var } & 0.109524 \\
\hline S.D. dependent var & 0.313042 & \multicolumn{2}{|l|}{ S.E. of regression } & 0.166789 \\
\hline Akaike info criterion & 0.333979 & \multicolumn{2}{|l|}{ Sum squared resid } & 5.452421 \\
\hline Schwarz criterion & 0.55712 & \multicolumn{2}{|l|}{ Log likelihood } & -21.06785 \\
\hline Hannan-Quinn criter. & 0.424187 & \multicolumn{2}{|l|}{ Deviance } & 42.13569 \\
\hline Restr. deviance & 145.1178 & \multicolumn{2}{|c|}{ Restr. log likelihood } & -72.5589 \\
\hline LR statistic & 102.9821 & \multicolumn{2}{|c|}{ Avg. log likelihood } & -0.100323 \\
\hline Prob(LR statistic) & 0 & & & \\
\hline
\end{tabular}




\subsection{Hồi quy lần 7}

Dependent Variable: $\mathrm{Y}$

Method: ML - Binary Logit (Quadratic hill climbing)

Date: 07/16/15 Time: 16:33

\begin{tabular}{|c|r|r|r|r|}
\hline Variable & Coefficient & Std. Error & z-Statistic & \multicolumn{1}{c|}{ Prob. } \\
\hline C & 1.488517 & 2.178125 & 0.683394 & 0.4944 \\
\hline X6 & -2.486584 & 1.820247 & -1.36607 & 0.1719 \\
\hline X8 & -4.460564 & 1.288116 & -3.462858 & 0.0005 \\
\hline X9 & -2.521 & 1.074439 & -2.346341 & 0.019 \\
\hline X10 & 0.152109 & 0.064672 & 2.351994 & 0.0187 \\
\hline X11 & -3.774233 & 1.295505 & -2.91333 & 0.0036 \\
\hline X13 & -3.298538 & 1.133299 & -2.910562 & 0.0036 \\
\hline X14 & 1.096872 & 0.470853 & 2.329541 & 0.0198 \\
\hline X16 & -0.641486 & 0.283042 & -2.266398 & 0.0234 \\
\hline X17 & 0.455309 & 0.382298 & 1.190978 & 0.2337 \\
\hline X18 & -3.357481 & 1.212571 & -2.768894 & 0.0056 \\
\hline X19 & -1.039739 & 0.334104 & -3.112019 & 0.0019 \\
\hline 1.432837 & 0.481022 & 2.978733 & 0.0029 \\
\hline McFadden R-squared & 0.702398 & Mean dependent var & 0.109524 \\
\hline S.D. dependent var & 0.313042 & S.E. of regression & 0.165401 \\
\hline Akaike info criterion & 0.329464 & Sum squared resid & 5.389403 \\
\hline Schwarz criterion & 0.536666 & Log likelihood & -21.5937 \\
\hline Hannan-Quinn criter. & 0.413228 & Deviance & 43.1874 \\
\hline Restr. deviance & 145.1178 & Restr. log likelihood & -72.5589 \\
\hline LR statistic & 101.9304 & Avg. log likelihood & -0.102827 \\
\hline Prob(LR statistic) & & \multicolumn{3}{|l|}{} \\
\hline
\end{tabular}




\subsection{Hồi quy lần 8}

Dependent Variable: Y

Method: ML - Binary Logit (Quadratic hill climbing)

Date: 07/16/15 Time: 16:36

\begin{tabular}{|c|c|c|c|c|}
\hline Variable & Coefficient & Std. Error & z-Statistic & Prob. \\
\hline $\mathrm{C}$ & 1.545319 & 2.201273 & 0.702012 & 0.4827 \\
\hline $\mathrm{X} 6$ & -2.347564 & 1.709291 & -1.373414 & 0.1696 \\
\hline $\mathrm{X} 7$ & -4.041282 & 1.123231 & -3.597907 & 0.0003 \\
\hline $\mathrm{X} 8$ & -2.427546 & 1.055805 & -2.299238 & 0.0215 \\
\hline $\mathrm{X} 9$ & 0.135481 & 0.057538 & 2.354657 & 0.0185 \\
\hline $\mathrm{X} 10$ & -3.372749 & 1.122017 & -3.00597 & 0.0026 \\
\hline X11 & -2.912931 & 1.009269 & -2.88618 & 0.0039 \\
\hline $\mathrm{X} 13$ & 1.049292 & 0.44826 & 2.340812 & 0.0192 \\
\hline $\mathrm{X} 14$ & -0.570608 & 0.25021 & -2.280514 & 0.0226 \\
\hline $\mathrm{X} 17$ & -2.910045 & 1.042661 & -2.790979 & 0.0053 \\
\hline $\mathrm{X} 18$ & -0.875698 & 0.267368 & -3.275255 & 0.0011 \\
\hline $\mathrm{X} 19$ & 1.348053 & 0.443087 & 3.042408 & 0.0023 \\
\hline McFadden R-squared & 0.692457 & \multicolumn{2}{|c|}{ Mean dependent var } & 0.109524 \\
\hline S.D. dependent var & 0.313042 & \multicolumn{2}{|c|}{ S.E. of regression } & 0.171054 \\
\hline Akaike info criterion & 0.326809 & \multicolumn{2}{|c|}{ Sum squared resid } & 5.793357 \\
\hline Schwarz criterion & 0.518072 & \multicolumn{2}{|l|}{ Log likelihood } & -22.315 \\
\hline Hannan-Quinn criter. & 0.40413 & \multicolumn{2}{|l|}{ Deviance } & 44.62992 \\
\hline Restr. deviance & 145.1178 & \multicolumn{2}{|c|}{ Restr. log likelihood } & -72.5589 \\
\hline LR statistic & 100.4879 & \multicolumn{2}{|c|}{ Avg. log likelihood } & -0.10626 \\
\hline Prob(LR statistic) & 0 & & & \\
\hline
\end{tabular}




\subsection{Hồi quy lần 9}

Dependent Variable: Y

Method: ML - Binary Logit (Quadratic hill climbing)

Date: 07/16/15 Time: 16:42

\begin{tabular}{|c|r|r|r|r|}
\hline Variable & Coefficient & Std. Error & z-Statistic & \multicolumn{1}{c|}{ Prob. } \\
\hline C & 2.470251 & 2.105918 & 1.173 & 0.2408 \\
\hline X7 & -3.701928 & 1.05389 & -3.5126 & 0.0004 \\
\hline X8 & -2.282386 & 1.01608 & -2.2463 & 0.0247 \\
\hline X10 & 0.123035 & 0.054776 & 2.2462 & 0.0247 \\
\hline X11 & -3.409516 & 1.098135 & -3.1048 & 0.0019 \\
\hline X13 & -3.121815 & 1.008177 & -3.0965 & 0.002 \\
\hline X14 & 0.911514 & 0.423032 & 2.1547 & 0.0312 \\
\hline X17 & -0.578343 & 0.245118 & -2.3595 & 0.0183 \\
\hline X18 & -2.898963 & 0.997269 & -2.9069 & 0.0037 \\
\hline X19 & -0.919615 & 0.271077 & -3.3925 & 0.0007 \\
\hline RcFadden R-squared & 1.309259 & 0.442452 & 2.9591 & 0.0031 \\
\hline S.D. dependent var & 0.675078 & Mean dependent var & 0.1095 \\
\hline Akaike info criterion & 0.313042 & S.E. of regression & 0.1761 \\
\hline Schwarz criterion & 0.329295 & Sum squared resid & 6.169 \\
\hline Hannan-Quinn criter. & 0.50462 & Log likelihood & -23.576 \\
\hline Restr. deviance & 0.400173 & Deviance & 47.152 \\
\hline LR statistic & 145.1178 & Restr. log likelihood & -72.559 \\
\hline Prob(LR statistic) & 97.96578 & Avg. log likelihood & -0.1123 \\
\hline & 0 & \multicolumn{3}{|l}{} \\
\hline
\end{tabular}


PHỤ LỤC 05: MA TRẬN HỆ SỐ TƯONG QUAN

\begin{tabular}{|c|c|c|c|c|c|c|c|c|c|c|c|c|c|}
\hline & $\mathbf{Y}$ & $\mathrm{X} 2$ & X3 & $\mathrm{X4}$ & X5 & X9 & X12 & X13 & X14 & X15 & X16 & X18 & X19 \\
\hline $\mathbf{Y}$ & 1.000 & -0.102 & -0.061 & 0.048 & -0.079 & -0.062 & -0.142 & 0.131 & -0.194 & -0.148 & -0.085 & -0.155 & 0.087 \\
\hline $\mathrm{X} 2$ & -0.102 & 1.000 & 0.607 & -0.476 & 0.784 & 0.146 & -0.062 & -0.197 & 0.158 & 0.820 & 0.749 & 0.525 & 0.410 \\
\hline X3 & -0.061 & 0.607 & 1.000 & -0.486 & 0.057 & 0.027 & -0.127 & -0.121 & -0.072 & 0.398 & 0.414 & 0.295 & 0.241 \\
\hline $\mathrm{X4}$ & 0.048 & -0.476 & -0.486 & 1.000 & -0.135 & 0.016 & 0.056 & 0.010 & -0.048 & -0.361 & -0.308 & -0.233 & -0.177 \\
\hline X5 & -0.079 & 0.784 & 0.057 & -0.135 & 1.000 & 0.167 & -0.024 & -0.170 & 0.225 & 0.679 & 0.611 & 0.421 & 0.367 \\
\hline X9 & -0.062 & 0.146 & 0.027 & 0.016 & 0.167 & 1.000 & 0.246 & 0.194 & 0.309 & 0.210 & 0.145 & 0.177 & 0.063 \\
\hline $\mathrm{X} 12$ & -0.142 & -0.062 & -0.127 & 0.056 & -0.024 & 0.246 & 1.000 & 0.015 & 0.033 & 0.040 & -0.025 & 0.037 & -0.076 \\
\hline $\mathrm{X} 13$ & 0.131 & -0.197 & -0.121 & 0.010 & -0.170 & 0.194 & 0.015 & 1.000 & 0.101 & -0.140 & -0.093 & -0.187 & -0.006 \\
\hline X14 & -0.194 & 0.158 & -0.072 & -0.048 & 0.225 & 0.309 & 0.033 & 0.101 & 1.000 & 0.299 & 0.181 & 0.249 & 0.085 \\
\hline X15 & -0.148 & 0.820 & 0.398 & -0.361 & 0.679 & 0.210 & 0.040 & -0.140 & 0.299 & 1.000 & 0.858 & 0.669 & 0.425 \\
\hline X16 & -0.085 & 0.749 & 0.414 & -0.308 & 0.611 & 0.145 & -0.025 & -0.093 & 0.181 & 0.858 & 1.000 & 0.575 & 0.472 \\
\hline X18 & -0.155 & 0.525 & 0.295 & -0.233 & 0.421 & 0.177 & 0.037 & -0.187 & 0.249 & 0.669 & 0.575 & 1.000 & 0.660 \\
\hline X19 & 0.087 & 0.410 & 0.241 & -0.177 & 0.367 & 0.063 & -0.076 & -0.006 & 0.085 & 0.425 & 0.472 & 0.660 & 1.000 \\
\hline
\end{tabular}


PHỤ LỤC 06: CƠ SỞ DŨ̃ LIỆU CHẠY MÔ HÌNH

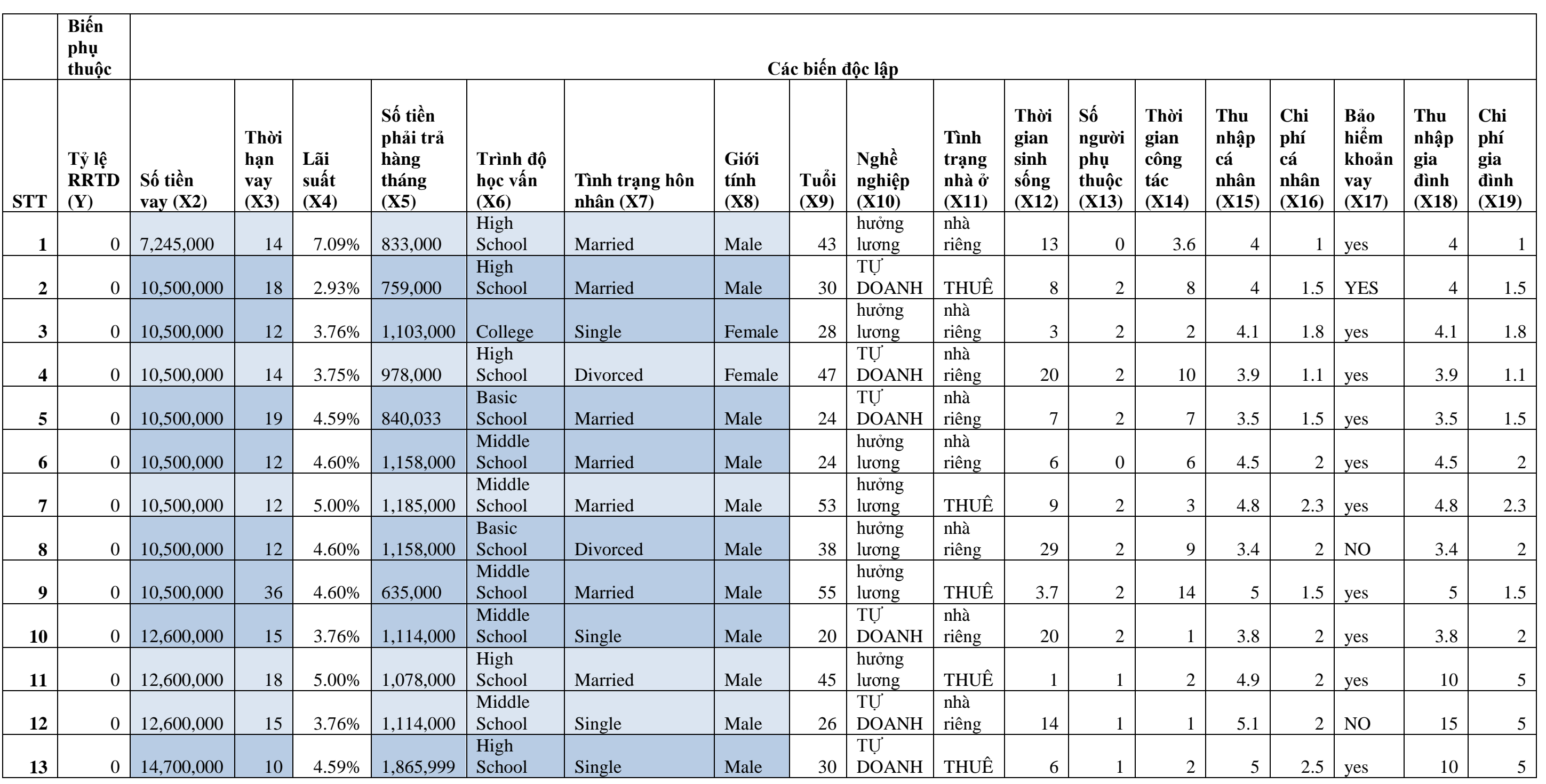




\begin{tabular}{|c|c|c|c|c|c|c|c|c|c|c|c|c|c|c|c|c|c|c|c|}
\hline 14 & 0 & $14,700,000$ & 9 & $4.59 \%$ & $2,031,000$ & $\begin{array}{l}\text { High } \\
\text { School }\end{array}$ & Married & Male & 27 & $\begin{array}{l}\text { hưởng } \\
\text { lương }\end{array}$ & $\begin{array}{l}\text { nhà } \\
\text { riêng }\end{array}$ & 2 & 0 & 2 & 6 & 3 & yes & 16 & 7 \\
\hline 15 & 0 & $15,000,000$ & 18 & $5.01 \%$ & $1,284,000$ & $\begin{array}{l}\text { Middle } \\
\text { School } \\
\end{array}$ & Married & Male & 29 & $\begin{array}{l}\text { hưởng } \\
\text { lương }\end{array}$ & $\begin{array}{l}\text { nhà } \\
\text { riêng }\end{array}$ & 10 & 1 & 5 & 4.6 & 2 & yes & 17 & 5 \\
\hline 16 & 0 & $15,000,000$ & 12 & $3.76 \%$ & $1,576,000$ & $\begin{array}{l}\text { High } \\
\text { School }\end{array}$ & Single & Male & 26 & $\begin{array}{l}\text { TƯ } \\
\text { DOANH }\end{array}$ & $\begin{array}{l}\text { nhà } \\
\text { riêng }\end{array}$ & 36 & 1 & 7 & 4.9 & 2.5 & yes & 10 & 6 \\
\hline 17 & 0 & $15,000,000$ & 36 & $3.76 \%$ & 860,000 & $\begin{array}{l}\text { High } \\
\text { School }\end{array}$ & Single & Male & 29 & $\begin{array}{l}\text { hưởng } \\
\text { lương }\end{array}$ & THUÊ & 2 & 1 & 3.9 & 5.9 & 2.5 & yes & 15 & 7 \\
\hline 18 & 0 & $15,000,000$ & 10 & $3.76 \%$ & $1,827,000$ & College & Single & Male & 23 & $\begin{array}{l}\text { hưởng } \\
\text { lương }\end{array}$ & THUÊ & 0.8 & 1 & 0.8 & 4.5 & 2 & $\mathrm{NO}$ & 14 & 8 \\
\hline 19 & 0 & $15,750,000$ & 15 & $5.01 \%$ & $1,518,000$ & $\begin{array}{l}\text { Middle } \\
\text { School }\end{array}$ & Divorced & Female & 57 & $\begin{array}{l}\text { hưởng } \\
\text { lương }\end{array}$ & $\begin{array}{l}\text { nhà } \\
\text { riêng }\end{array}$ & 8 & 2 & 10 & 6.1 & 3 & $\mathrm{NO}$ & 16 & 6 \\
\hline 20 & 0 & $15,750,000$ & 20 & $3.76 \%$ & $1,134,000$ & $\begin{array}{l}\text { High } \\
\text { School }\end{array}$ & Married & Male & 38 & $\begin{array}{l}\text { TỬ } \\
\text { DOANH }\end{array}$ & $\begin{array}{l}\text { nhà } \\
\text { riêng }\end{array}$ & 20 & 3 & 3 & 5.6 & 2 & yes & 10 & 6 \\
\hline 21 & 0 & $15,750,000$ & 12 & $3.75 \%$ & $1,654,000$ & $\begin{array}{l}\text { Middle } \\
\text { School }\end{array}$ & Married & Female & 39 & $\begin{array}{l}\text { hưởng } \\
\text { lương }\end{array}$ & THUÊ & 3 & 2 & 10 & 4.9 & 2.3 & yes & 11 & 7 \\
\hline 22 & 0 & $15,750,000$ & 18 & $3.75 \%$ & $1,219,000$ & $\begin{array}{l}\text { Middle } \\
\text { School }\end{array}$ & Married & Female & 38 & $\begin{array}{l}\text { hưởng } \\
\text { lương }\end{array}$ & $\begin{array}{l}\text { nhà } \\
\text { riêng }\end{array}$ & 12 & 2 & 5 & 3.9 & 2 & yes & 12 & 5 \\
\hline 23 & 0 & $15,750,000$ & 12 & $5.01 \%$ & $1,778,000$ & $\begin{array}{l}\text { Middle } \\
\text { School }\end{array}$ & Single & Male & 28 & $\begin{array}{l}\text { TỰ } \\
\text { DOANH }\end{array}$ & THUÊ & 1 & 2 & 1 & 5.6 & 3 & YES & 13 & 6 \\
\hline 24 & 0 & $15,750,000$ & 18 & $5.01 \%$ & $1,348,000$ & $\begin{array}{l}\text { Middle } \\
\text { School }\end{array}$ & Other & Female & 26 & $\begin{array}{l}\text { hưởng } \\
\text { lương }\end{array}$ & $\begin{array}{l}\text { nhà } \\
\text { riêng }\end{array}$ & 20 & 2 & 0.6 & 4.9 & 2 & yes & 10 & 4 \\
\hline 25 & 0 & $15,750,000$ & 24 & $5.01 \%$ & $1,142,000$ & $\begin{array}{l}\text { Middle } \\
\text { School }\end{array}$ & Married & Female & 34 & $\begin{array}{l}\text { TƯ } \\
\text { DOANH }\end{array}$ & $\begin{array}{l}\text { nhà } \\
\text { riêng }\end{array}$ & 16 & 2 & 5 & 4.8 & 2 & yes & 8 & 5 \\
\hline 26 & 0 & $15,750,000$ & 12 & $3.75 \%$ & $1,654,000$ & $\begin{array}{l}\text { Working } \\
\text { Cerfiticate }\end{array}$ & Married & Male & 30 & $\begin{array}{l}\text { TỬ } \\
\text { DOANH }\end{array}$ & $\begin{array}{l}\text { nhà } \\
\text { riêng }\end{array}$ & 24 & 2 & 3 & 5.1 & 2 & yes & 8 & 4 \\
\hline 27 & 0 & $15,750,000$ & 24 & $3.75 \%$ & $1,007,000$ & $\begin{array}{l}\text { High } \\
\text { School }\end{array}$ & Married & Male & 52 & $\begin{array}{l}\text { hưởng } \\
\text { lương }\end{array}$ & $\begin{array}{l}\text { nhà } \\
\text { riêng }\end{array}$ & 10 & 2 & 10 & 4.9 & 2.5 & yes & 8 & 5 \\
\hline 28 & 0 & $15,825,000$ & 24 & $5.00 \%$ & $1,147,000$ & $\begin{array}{l}\text { Middle } \\
\text { School }\end{array}$ & Widow/Widower & Female & 49 & $\begin{array}{l}\text { hưởng } \\
\text { lương }\end{array}$ & THUÊ & 2 & 2 & 5 & 4.1 & 2 & yes & 11 & 6 \\
\hline 29 & 0 & $15,825,000$ & 18 & $3.75 \%$ & $1,225,000$ & $\begin{array}{l}\text { High } \\
\text { School }\end{array}$ & Single & Female & 43 & $\begin{array}{l}\text { hưởng } \\
\text { lương }\end{array}$ & $\begin{array}{l}\text { nhà } \\
\text { riêng }\end{array}$ & 15 & 2 & 12 & 4.3 & 2.5 & NO & 10 & 5 \\
\hline 30 & 0 & $16,500,000$ & 18 & $3.76 \%$ & $1,278,000$ & $\begin{array}{l}\text { Middle } \\
\text { School }\end{array}$ & Married & Female & 29 & $\begin{array}{l}\text { hưởng } \\
\text { lương }\end{array}$ & THUÊ & 2 & 2 & 6 & 4.2 & 3 & yes & 10 & 7 \\
\hline 31 & 0 & $16,800,000$ & 18 & $5.01 \%$ & $1,438,000$ & $\begin{array}{l}\text { Working } \\
\text { Cerfiticate }\end{array}$ & Single & Female & 23 & $\begin{array}{l}\text { TỬ } \\
\text { DOANH }\end{array}$ & $\begin{array}{l}\text { nhà } \\
\text { riêng }\end{array}$ & 15 & 2 & 4 & 5.9 & 2 & yes & 15 & 8 \\
\hline 32 & 0 & $16,800,000$ & 12 & $4.59 \%$ & $1,852,000$ & $\begin{array}{l}\text { Middle } \\
\text { School }\end{array}$ & Married & Male & 42 & $\begin{array}{l}\text { hưởng } \\
\text { lương }\end{array}$ & THUÊ & 3 & 2 & 20 & 7.6 & 2.5 & yes & 10 & 5 \\
\hline
\end{tabular}




\begin{tabular}{|c|c|c|c|c|c|c|c|c|c|c|c|c|c|c|c|c|c|c|c|}
\hline 33 & 0 & $17,640,000$ & 19 & $4.59 \%$ & $1,411,255$ & $\begin{array}{l}\text { Middle } \\
\text { School }\end{array}$ & Married & Male & 49 & $\begin{array}{l}\text { TỤ๋ } \\
\text { DOANH }\end{array}$ & $\begin{array}{l}\text { nhà } \\
\text { riêng }\end{array}$ & 17 & 2 & 15 & 4.5 & 2.5 & $\mathrm{NO}$ & 11 & 6 \\
\hline 34 & 0 & $17,850,000$ & 20 & $3.75 \%$ & $1,285,000$ & $\begin{array}{l}\text { Basic } \\
\text { School }\end{array}$ & Married & Female & 46 & $\begin{array}{l}\text { TÜ } \\
\text { DOANH }\end{array}$ & THUÊ & 0.6 & 2 & 12 & 5.9 & 2 & yes & 12 & 7 \\
\hline 35 & 0 & $17,850,000$ & 12 & $5.00 \%$ & $2,014,000$ & $\begin{array}{l}\text { Middle } \\
\text { School }\end{array}$ & Married & Female & 51 & $\begin{array}{l}\text { hưởng } \\
\text { lương }\end{array}$ & $\begin{array}{l}\text { nhà } \\
\text { riêng }\end{array}$ & 10 & 2 & 17 & 7.1 & 3 & yes & 10 & 7 \\
\hline 36 & 0 & $17,850,000$ & 18 & $3.75 \%$ & $1,382,000$ & $\begin{array}{l}\text { Middle } \\
\text { School }\end{array}$ & Married & Female & 36 & $\begin{array}{l}\text { hưởng } \\
\text { lương }\end{array}$ & $\begin{array}{l}\text { nhà } \\
\text { riêng }\end{array}$ & 15 & 2 & 12 & 4.8 & 2 & yes & 8 & 4 \\
\hline 37 & 0 & $18,000,000$ & 18 & $3.76 \%$ & $1,394,000$ & $\begin{array}{l}\text { Middle } \\
\text { School }\end{array}$ & Married & Female & 38 & $\begin{array}{l}\text { TƯ } \\
\text { DOANH }\end{array}$ & $\begin{array}{l}\text { nhà } \\
\text { riêng }\end{array}$ & 5 & 2 & 11 & 5.5 & 2.3 & yes & 14 & 6 \\
\hline 38 & 0 & $18,375,000$ & 24 & $5.00 \%$ & $1,332,000$ & $\begin{array}{l}\text { Basic } \\
\text { School }\end{array}$ & Married & Female & 37 & $\begin{array}{l}\text { hưởng } \\
\text { lương }\end{array}$ & THUÊ & 1 & 2 & 5 & 4.9 & 2 & yes & 10 & 6 \\
\hline 39 & 0 & $18,900,000$ & 24 & $3.76 \%$ & $1,209,000$ & $\begin{array}{l}\text { High } \\
\text { School }\end{array}$ & Single & Male & 27 & $\begin{array}{l}\text { hưởng } \\
\text { lương }\end{array}$ & THUÊ & 2 & 2 & 2 & 4.4 & 3 & NO & 10 & 4 \\
\hline 40 & 0 & $18,900,000$ & 24 & $3.76 \%$ & $1,209,000$ & $\begin{array}{l}\text { Middle } \\
\text { School }\end{array}$ & Single & Male & 22 & $\begin{array}{l}\text { hưởng } \\
\text { lương }\end{array}$ & $\begin{array}{l}\text { nhà } \\
\text { riêng }\end{array}$ & 18 & 2 & 2 & 4.9 & 2 & NO & 11 & 5 \\
\hline 41 & 0 & $18,900,000$ & 24 & $3.76 \%$ & $1,209,000$ & $\begin{array}{l}\text { Middle } \\
\text { School }\end{array}$ & Single & Male & 26 & $\begin{array}{l}\text { TƯ } \\
\text { DOANH }\end{array}$ & $\begin{array}{l}\text { nhà } \\
\text { riêng }\end{array}$ & 20 & 0 & 1 & 5.6 & 2 & yes & 12 & 6 \\
\hline 42 & 0 & $18,900,000$ & 24 & $3.76 \%$ & $1,209,000$ & $\begin{array}{l}\text { Middle } \\
\text { School }\end{array}$ & Widow/Widower & Female & 50 & & THUÊ & 2 & 0 & 3 & 5.5 & 2 & yes & 13 & 7 \\
\hline 43 & 0 & $18,900,000$ & 19 & $4.59 \%$ & $1,512,059$ & $\begin{array}{l}\text { High } \\
\text { School }\end{array}$ & Married & Female & 42 & $\begin{array}{l}\text { hưởng } \\
\text { lương }\end{array}$ & $\begin{array}{l}\text { nhà } \\
\text { riêng }\end{array}$ & 20 & 0 & 1 & 5.9 & 2.5 & yes & 14 & 7 \\
\hline 44 & 0 & $18,900,000$ & 24 & $3.76 \%$ & $1,209,000$ & $\begin{array}{l}\text { Middle } \\
\text { School }\end{array}$ & Single & Female & 33 & $\begin{array}{l}\text { TƯ } \\
\text { DOANH }\end{array}$ & THUÊ & 3 & 0 & 3.6 & 6.7 & 3 & YES & 15 & 4 \\
\hline 45 & 0 & $18,900,000$ & 18 & $3.75 \%$ & $1,463,000$ & $\begin{array}{l}\text { Middle } \\
\text { School }\end{array}$ & Married & Female & 27 & $\begin{array}{l}\text { hưởng } \\
\text { lương }\end{array}$ & $\begin{array}{l}\text { nhà } \\
\text { riêng }\end{array}$ & 40 & 0 & 8 & 7.7 & 3 & yes & 16 & 6 \\
\hline 46 & 0 & $18,900,000$ & 24 & $3.76 \%$ & $1,209,000$ & $\begin{array}{l}\text { Middle } \\
\text { School }\end{array}$ & Married & Female & 34 & $\begin{array}{l}\text { TƯ } \\
\text { DOANH }\end{array}$ & $\begin{array}{l}\text { nhà } \\
\text { riêng }\end{array}$ & 30 & 0 & 2 & 5.5 & 2 & yes & 17 & 6 \\
\hline 47 & 0 & $18,900,000$ & 12 & $5.00 \%$ & $2,133,000$ & $\begin{array}{l}\text { Middle } \\
\text { School }\end{array}$ & Married & Male & 42 & $\begin{array}{l}\text { TƯ } \\
\text { DOANH }\end{array}$ & $\begin{array}{l}\text { nhà } \\
\text { riêng }\end{array}$ & 20 & 0 & 10 & 8 & 4 & yes & 18 & 4 \\
\hline 48 & 0 & $18,900,000$ & 36 & $3.76 \%$ & 966,000 & $\begin{array}{l}\text { Middle } \\
\text { School }\end{array}$ & Divorced & Female & 25 & $\begin{array}{l}\text { hưởng } \\
\text { lương }\end{array}$ & $\begin{array}{l}\text { nhà } \\
\text { riêng }\end{array}$ & 10 & 0 & 4 & 4.1 & 3 & yes & 10 & 5 \\
\hline 49 & 0 & $18,900,000$ & 10 & $3.76 \%$ & $2,302,000$ & $\begin{array}{l}\text { High } \\
\text { School }\end{array}$ & Married & Male & 47 & $\begin{array}{l}\text { hưởng } \\
\text { lương }\end{array}$ & THUÊ & 3 & 3 & 6 & 6.7 & 3.3 & yes & 8 & 4 \\
\hline 50 & 0 & $18,900,000$ & 10 & $3.76 \%$ & $2,302,000$ & $\begin{array}{l}\text { High } \\
\text { School }\end{array}$ & Married & Male & 47 & $\begin{array}{l}\text { hưởng } \\
\text { lương }\end{array}$ & $\begin{array}{l}\text { nhà } \\
\text { riêng }\end{array}$ & 30 & 3 & 3 & 8.7 & 4.1 & NO & 10 & 5 \\
\hline 51 & 0 & $19,000,000$ & 23 & $5.00 \%$ & $1,409,000$ & $\begin{array}{l}\text { Working } \\
\text { Cerfiticate }\end{array}$ & Married & Female & 26 & $\begin{array}{l}\text { hưởng } \\
\text { lương }\end{array}$ & THUÊ & 2 & 3 & 3 & 4.1 & 2 & yes & 6 & 4 \\
\hline
\end{tabular}




\begin{tabular}{|c|c|c|c|c|c|c|c|c|c|c|c|c|c|c|c|c|c|c|c|}
\hline 52 & 0 & $19,264,547$ & 14 & $4.59 \%$ & $1,896,000$ & $\begin{array}{l}\text { Middle } \\
\text { School }\end{array}$ & Divorced & Female & 27 & $\begin{array}{l}\text { TỤ๋ } \\
\text { DOANH }\end{array}$ & $\begin{array}{l}\text { nhà } \\
\text { riêng }\end{array}$ & 15 & 3 & 3 & 6.1 & 3.1 & yes & 8 & 4 \\
\hline 53 & 0 & $19,500,000$ & 19 & $5.00 \%$ & $1,614,000$ & $\begin{array}{l}\text { Middle } \\
\text { School } \\
\end{array}$ & Married & Female & 51 & $\begin{array}{l}\text { hưởng } \\
\text { lương }\end{array}$ & THUÊ & 1 & 3 & 1 & 5.1 & 2.6 & yes & 5.1 & 2.6 \\
\hline 54 & 0 & $19,950,000$ & 20 & $3.75 \%$ & $1,436,000$ & $\begin{array}{l}\text { Middle } \\
\text { School }\end{array}$ & Married & Female & 40 & $\begin{array}{l}\text { TƯ } \\
\text { DOANH }\end{array}$ & $\begin{array}{l}\text { nhà } \\
\text { riêng }\end{array}$ & 10 & 0 & 2 & 5.9 & 3 & $\mathrm{NO}$ & 5.9 & 3 \\
\hline 55 & 0 & $19,950,000$ & 24 & $3.76 \%$ & $1,276,000$ & $\begin{array}{l}\text { High } \\
\text { School }\end{array}$ & Married & Female & 30 & $\begin{array}{l}\text { TỬ } \\
\text { DOANH }\end{array}$ & THUÊ & 3 & 0 & 1 & 4.7 & 1.9 & yes & 4.7 & 1.9 \\
\hline 56 & 0 & $20,000,000$ & 12 & $3.76 \%$ & $2,101,000$ & Bachelor & Married & Male & 36 & $\begin{array}{l}\text { hưởng } \\
\text { lương }\end{array}$ & $\begin{array}{l}\text { nhà } \\
\text { riêng }\end{array}$ & 15 & 0 & 2 & 5.1 & 2.1 & yes & 5.1 & 2.1 \\
\hline 57 & 0 & $20,000,000$ & 24 & $2.51 \%$ & $1,119,000$ & $\begin{array}{l}\text { High } \\
\text { School }\end{array}$ & Married & Male & 45 & $\begin{array}{l}\text { hưởng } \\
\text { lương }\end{array}$ & $\begin{array}{l}\text { nhà } \\
\text { riêng }\end{array}$ & 5 & 0 & 2 & 4.4 & 2 & yes & 4.4 & 2 \\
\hline 58 & 0 & $20,616,080$ & 24 & $4.60 \%$ & $1,436,000$ & $\begin{array}{l}\text { High } \\
\text { School }\end{array}$ & Single & Male & 24 & $\begin{array}{l}\text { TƯ } \\
\text { DOANH }\end{array}$ & $\begin{array}{l}\text { nhà } \\
\text { riêng }\end{array}$ & 3 & 0 & 5 & 6.4 & 3.5 & yes & 6.4 & 3.5 \\
\hline 59 & 0 & $21,000,000$ & 24 & $3.76 \%$ & $1,343,000$ & $\begin{array}{l}\text { Middle } \\
\text { School }\end{array}$ & Married & Female & 24 & $\begin{array}{l}\text { hưởng } \\
\text { lương }\end{array}$ & THUÊ & 0.7 & 0 & 4 & 5 & 2 & yes & 5 & 2 \\
\hline 60 & 0 & $21,000,000$ & 24 & $3.76 \%$ & $1,343,000$ & $\begin{array}{l}\text { Middle } \\
\text { School }\end{array}$ & Married & Male & 26 & $\begin{array}{l}\text { hưởng } \\
\text { lương }\end{array}$ & THUÊ & 1 & 0 & 3.9 & 6 & 3 & NO & 6 & 3 \\
\hline 61 & 0 & $21,000,000$ & 24 & $5.00 \%$ & $1,522,000$ & $\begin{array}{l}\text { Middle } \\
\text { School }\end{array}$ & Single & Female & 22 & $\begin{array}{l}\text { hưởng } \\
\text { lương }\end{array}$ & $\begin{array}{l}\text { nhà } \\
\text { riêng }\end{array}$ & 12 & 1 & 0.8 & 3.7 & 1.5 & $\mathrm{NO}$ & 3.7 & 1.5 \\
\hline 62 & 0 & $21,000,000$ & 24 & $3.76 \%$ & $1,343,000$ & $\begin{array}{l}\text { Middle } \\
\text { School }\end{array}$ & Married & Female & 25 & $\begin{array}{l}\text { TƯ } \\
\text { DOANH }\end{array}$ & $\begin{array}{l}\text { nhà } \\
\text { riêng }\end{array}$ & 1 & 1 & 3 & 5.6 & 1.9 & yes & 5.6 & 1.9 \\
\hline 63 & 0 & $21,000,000$ & 26 & $3.75 \%$ & $1,279,000$ & $\begin{array}{l}\text { Middle } \\
\text { School }\end{array}$ & Married & Male & 38 & & THUÊ & 0.9 & 3 & 3 & 5.4 & 2 & yes & 5.4 & 2 \\
\hline 64 & 0 & $21,000,000$ & 20 & $3.76 \%$ & $1,512,000$ & $\begin{array}{l}\text { Middle } \\
\text { School }\end{array}$ & Married & Female & 33 & $\begin{array}{l}\text { hưởng } \\
\text { lương }\end{array}$ & $\begin{array}{l}\text { nhà } \\
\text { riêng }\end{array}$ & 10 & 3 & 10 & 4.9 & 3 & yes & 4.9 & 3 \\
\hline 65 & 0 & $21,000,000$ & 24 & $3.76 \%$ & $1,343,000$ & $\begin{array}{l}\text { Middle } \\
\text { School }\end{array}$ & Married & Female & 25 & $\begin{array}{l}\text { TƯ } \\
\text { DOANH }\end{array}$ & THUÊ & 1 & 1 & 5 & 5.6 & 4 & YES & 5.6 & 4 \\
\hline 66 & 0 & $21,000,000$ & 28 & $3.76 \%$ & $1,225,000$ & $\begin{array}{l}\text { Middle } \\
\text { School }\end{array}$ & Single & Female & 35 & $\begin{array}{l}\text { hưởng } \\
\text { lương }\end{array}$ & $\begin{array}{l}\text { nhà } \\
\text { riêng }\end{array}$ & 10 & 3 & 1 & 4.9 & 3 & yes & 4.9 & 3 \\
\hline 67 & 0 & $21,000,000$ & 30 & $3.75 \%$ & $1,178,000$ & $\begin{array}{l}\text { High } \\
\text { School }\end{array}$ & Married & Female & 32 & $\begin{array}{l}\text { TƯ } \\
\text { DOANH }\end{array}$ & $\begin{array}{l}\text { nhà } \\
\text { riêng }\end{array}$ & 15 & 3 & 0.6 & 5.6 & 3 & yes & 5.6 & 3 \\
\hline 68 & 0 & $21,000,000$ & 36 & $2.50 \%$ & 892,000 & College & Married & Female & 42 & $\begin{array}{l}\text { TƯ } \\
\text { DOANH }\end{array}$ & $\begin{array}{l}\text { nhà } \\
\text { riêng }\end{array}$ & 17 & 3 & 5 & 3.9 & 1.3 & yes & $\underline{10}$ & 6 \\
\hline 69 & 0 & $21,000,000$ & 24 & $3.76 \%$ & $1,343,000$ & $\begin{array}{l}\text { High } \\
\text { School }\end{array}$ & Single & Male & 25 & $\begin{array}{l}\text { hưởng } \\
\text { lương }\end{array}$ & $\begin{array}{l}\text { nhà } \\
\text { riêng }\end{array}$ & 19 & 0 & 3 & 5.5 & 4.1 & yes & 9 & 4 \\
\hline 70 & 0 & $21,000,000$ & 23 & $3.75 \%$ & $1,379,000$ & $\begin{array}{l}\text { Middle } \\
\text { School }\end{array}$ & Married & Female & 28 & $\begin{array}{l}\text { hưởng } \\
\text { lương }\end{array}$ & THUÊ & 0.6 & 0 & 3 & 6.7 & 2 & yes & 8 & 5 \\
\hline
\end{tabular}




\begin{tabular}{|c|c|c|c|c|c|c|c|c|c|c|c|c|c|c|c|c|c|c|c|}
\hline 71 & 0 & $21,000,000$ & 24 & $2.51 \%$ & $1,175,000$ & $\begin{array}{l}\text { High } \\
\text { School }\end{array}$ & Married & Male & 38 & $\begin{array}{l}\text { hưởng } \\
\text { lương }\end{array}$ & $\begin{array}{l}\text { nhà } \\
\text { riêng }\end{array}$ & 17 & 2 & 5 & 5.9 & 3.1 & $\mathrm{NO}$ & 7 & 6 \\
\hline 72 & 0 & $21,000,000$ & 24 & $3.76 \%$ & $1,343,000$ & $\begin{array}{l}\text { Middle } \\
\text { School } \\
\end{array}$ & Divorced & Female & 25 & $\begin{array}{l}\text { hưởng } \\
\text { lương }\end{array}$ & THUÊ & 3 & 2 & 3 & 7.7 & 2.6 & yes & 10 & 7 \\
\hline 73 & 0 & $21,000,000$ & 24 & $3.76 \%$ & $1,343,000$ & $\begin{array}{l}\text { High } \\
\text { School }\end{array}$ & Married & Female & 46 & $\begin{array}{l}\text { TƯ } \\
\text { DOANH }\end{array}$ & $\begin{array}{l}\text { nhà } \\
\text { riêng }\end{array}$ & 46 & 1 & 6 & 6.4 & 3 & yes & 11 & 7 \\
\hline 74 & 0 & $21,000,000$ & 24 & $3.76 \%$ & $1,343,000$ & $\begin{array}{l}\text { Middle } \\
\text { School }\end{array}$ & Married & Male & 43 & $\begin{array}{l}\text { hưởng } \\
\text { lương }\end{array}$ & THUÊ & 4 & 0 & 4 & 5.1 & 1.9 & yes & 12 & 4 \\
\hline 75 & 0 & $21,000,000$ & 10 & $2.92 \%$ & $2,452,000$ & $\begin{array}{l}\text { Middle } \\
\text { School }\end{array}$ & Married & Female & 48 & $\begin{array}{l}\text { TỬ } \\
\text { DOANH }\end{array}$ & $\begin{array}{l}\text { nhà } \\
\text { riêng }\end{array}$ & 2 & 3 & 20 & 8.1 & 2.1 & $\mathrm{NO}$ & 13 & 6 \\
\hline 76 & 0 & $21,000,000$ & 24 & $3.76 \%$ & $1,343,000$ & $\begin{array}{l}\text { Middle } \\
\text { School }\end{array}$ & Divorced & Female & 42 & $\begin{array}{l}\text { TỬ } \\
\text { DOANH }\end{array}$ & THUÊ & 3 & 2 & 15 & 4.9 & 2 & yes & 10 & 6 \\
\hline 77 & 0 & $21,000,000$ & 18 & $3.76 \%$ & $1,626,000$ & $\begin{array}{l}\text { Middle } \\
\text { School }\end{array}$ & Married & Male & 31 & $\begin{array}{l}\text { hưởng } \\
\text { lương }\end{array}$ & $\begin{array}{l}\text { nhà } \\
\text { riêng }\end{array}$ & 10 & 1 & 11 & 5.9 & 3.5 & yes & 8 & 4 \\
\hline 78 & 0 & $21,000,000$ & 12 & $3.76 \%$ & $2,206,000$ & $\begin{array}{l}\text { High } \\
\text { School }\end{array}$ & Married & Male & 42 & $\begin{array}{l}\text { hưởng } \\
\text { lương }\end{array}$ & $\begin{array}{l}\text { nhà } \\
\text { riêng }\end{array}$ & 13 & 3 & 10 & 6.3 & 2 & yes & 9 & 5 \\
\hline 79 & 0 & $21,000,000$ & 36 & $3.75 \%$ & $1,073,000$ & College & Divorced & Male & 39 & $\begin{array}{l}\text { TƯ } \\
\text { DOANH }\end{array}$ & $\begin{array}{l}\text { nhà } \\
\text { riêng }\end{array}$ & 10 & 2 & 10 & 4.1 & 3 & yes & 6 & 4 \\
\hline 80 & 0 & $21,000,000$ & 36 & $3.75 \%$ & $1,073,000$ & $\begin{array}{l}\text { High } \\
\text { School }\end{array}$ & Married & Male & 29 & $\begin{array}{l}\text { hưởng } \\
\text { lương }\end{array}$ & THUÊ & 1 & 1 & 1 & 4.2 & 2.5 & yes & 8 & 6 \\
\hline 81 & 0 & $21,000,000$ & 24 & $3.76 \%$ & $1,343,000$ & $\begin{array}{l}\text { Basic } \\
\text { School }\end{array}$ & Married & Female & 51 & $\begin{array}{l}\text { hưởng } \\
\text { lương }\end{array}$ & THUÊ & 3 & 3 & 5 & 5.8 & 1.9 & $\mathrm{NO}$ & 10 & 7 \\
\hline 82 & 0 & $21,000,000$ & 24 & $3.76 \%$ & $1,343,000$ & $\begin{array}{l}\text { High } \\
\text { School }\end{array}$ & Married & Male & 23 & $\begin{array}{l}\text { hưởng } \\
\text { lương }\end{array}$ & $\begin{array}{l}\text { nhà } \\
\text { riêng }\end{array}$ & 23 & 0 & 2 & 5.4 & 2 & $\mathrm{NO}$ & 10 & 7 \\
\hline 83 & 0 & $21,000,000$ & 24 & $2.92 \%$ & $1,229,000$ & $\begin{array}{l}\text { Middle } \\
\text { School }\end{array}$ & Married & Male & 38 & $\begin{array}{l}\text { TỬ } \\
\text { DOANH }\end{array}$ & $\begin{array}{l}\text { nhà } \\
\text { riêng }\end{array}$ & 2 & 3 & 2 & 8.1 & 3 & yes & 13 & 4 \\
\hline 84 & 0 & $21,000,000$ & 24 & $3.76 \%$ & $1,343,000$ & $\begin{array}{l}\text { Middle } \\
\text { School }\end{array}$ & Married & Female & 39 & $\begin{array}{l}\text { hưởng } \\
\text { lương }\end{array}$ & THUÊ & 5 & 3 & 1 & 6.4 & 4 & yes & 10 & 6 \\
\hline 85 & 0 & $21,000,000$ & 24 & $3.76 \%$ & $1,343,000$ & $\begin{array}{l}\text { High } \\
\text { School }\end{array}$ & Single & Female & 27 & $\begin{array}{l}\text { hưởng } \\
\text { lương }\end{array}$ & $\begin{array}{l}\text { nhà } \\
\text { riêng }\end{array}$ & 4 & 0 & 3 & 7.3 & 4 & yes & 11 & 6 \\
\hline 86 & 0 & $21,000,000$ & 24 & $2.92 \%$ & $1,229,000$ & $\begin{array}{l}\text { High } \\
\text { School }\end{array}$ & Single & Female & 22 & $\begin{array}{l}\text { TƯ } \\
\text { DOANH }\end{array}$ & THUÊ & 2 & 0 & 1 & 4.5 & 3 & YES & 8 & 4 \\
\hline 87 & 0 & $21,000,000$ & 24 & $3.76 \%$ & $1,343,000$ & Bachelor & Married & Male & 34 & $\begin{array}{l}\text { hưởng } \\
\text { lương }\end{array}$ & $\begin{array}{l}\text { nhà } \\
\text { riêng }\end{array}$ & 4 & 0 & 3.6 & 7.4 & 3 & yes & 13 & 5 \\
\hline 88 & 0 & $21,000,000$ & 24 & $2.92 \%$ & $1,229,000$ & $\begin{array}{l}\text { Middle } \\
\text { School }\end{array}$ & Married & Male & 24 & $\begin{array}{l}\text { TỬ } \\
\text { DOANH }\end{array}$ & $\begin{array}{l}\text { nhà } \\
\text { riêng }\end{array}$ & 1 & 1 & 8 & 7.5 & 1.3 & yes & 14 & 4 \\
\hline 89 & 0 & $21,000,000$ & 24 & $5.00 \%$ & $1,522,000$ & College & Other & Female & 56 & $\begin{array}{l}\text { TỬ } \\
\text { DOANH }\end{array}$ & $\begin{array}{l}\text { nhà } \\
\text { riêng }\end{array}$ & 20 & 3 & 2 & 6.4 & 4.1 & yes & 12 & 5 \\
\hline
\end{tabular}




\begin{tabular}{|c|c|c|c|c|c|c|c|c|c|c|c|c|c|c|c|c|c|c|c|}
\hline 90 & 0 & $21,100,000$ & 15 & $3.75 \%$ & $1,865,000$ & $\begin{array}{l}\text { Basic } \\
\text { School }\end{array}$ & Married & Male & 46 & $\begin{array}{l}\text { hưởng } \\
\text { lương }\end{array}$ & $\begin{array}{l}\text { nhà } \\
\text { riêng }\end{array}$ & 10 & 3 & 10 & 7.9 & 2 & yes & 5 & 4 \\
\hline 91 & 0 & $21,100,000$ & 24 & $3.75 \%$ & $1,349,000$ & $\begin{array}{l}\text { Middle } \\
\text { School }\end{array}$ & Single & Male & 22 & $\begin{array}{l}\text { hưởng } \\
\text { lương }\end{array}$ & THUÊ & 3 & 4 & 4 & 5.1 & 3.1 & yes & 10 & 4 \\
\hline 92 & 0 & $21,640,428$ & 24 & $4.59 \%$ & $1,507,000$ & $\begin{array}{l}\text { Middle } \\
\text { School }\end{array}$ & Single & Male & 29 & $\begin{array}{l}\text { hưởng } \\
\text { lương }\end{array}$ & $\begin{array}{l}\text { nhà } \\
\text { riêng }\end{array}$ & 8 & 1 & 6 & 4.9 & 2.6 & $\mathrm{NO}$ & 7 & 5 \\
\hline 93 & 0 & $22,000,000$ & 24 & $3.76 \%$ & $1,407,000$ & $\begin{array}{l}\text { Middle } \\
\text { School }\end{array}$ & Married & Female & 31 & $\begin{array}{l}\text { hưởng } \\
\text { lương }\end{array}$ & THUÊ & 3 & 1 & 3 & 6.1 & 3 & yes & 10 & 4 \\
\hline 94 & 0 & $22,050,000$ & 24 & $3.75 \%$ & $1,410,000$ & $\begin{array}{l}\text { Middle } \\
\text { School }\end{array}$ & Married & Male & 50 & $\begin{array}{l}\text { TƯ } \\
\text { DOANH }\end{array}$ & $\begin{array}{l}\text { nhà } \\
\text { riêng }\end{array}$ & 20 & 3 & 9 & 5 & 1.9 & yes & 8 & 4 \\
\hline 95 & 0 & $22,050,000$ & 24 & $5.00 \%$ & $1,598,000$ & $\begin{array}{l}\text { Middle } \\
\text { School }\end{array}$ & Married & Female & 26 & $\begin{array}{l}\text { hưởng } \\
\text { lương }\end{array}$ & THUÊ & 7 & 1 & 6 & 4.8 & 2.1 & yes & 13 & 6 \\
\hline 96 & 0 & $22,050,000$ & 24 & $3.75 \%$ & $1,410,000$ & $\begin{array}{l}\text { High } \\
\text { School }\end{array}$ & Married & Female & 21 & $\begin{array}{l}\text { TƯ } \\
\text { DOANH }\end{array}$ & $\begin{array}{l}\text { nhà } \\
\text { riêng }\end{array}$ & 6 & 0 & 1 & 4.9 & 2 & NO & 10 & 7 \\
\hline 97 & 0 & $23,100,000$ & 24 & $3.75 \%$ & $1,477,000$ & $\begin{array}{l}\text { Basic } \\
\text { School }\end{array}$ & Married & Male & 36 & $\begin{array}{l}\text { TƯ } \\
\text { DOANH }\end{array}$ & THUÊ & 9 & 0 & 2 & 5.5 & 3.5 & yes & 11 & 7 \\
\hline 98 & 0 & $23,100,000$ & 24 & $3.75 \%$ & $1,477,000$ & $\begin{array}{l}\text { Middle } \\
\text { School }\end{array}$ & Married & Female & 32 & $\begin{array}{l}\text { hưởng } \\
\text { lương }\end{array}$ & $\begin{array}{l}\text { nhà } \\
\text { riêng }\end{array}$ & 29 & 0 & 1 & 5.5 & 2 & yes & 8 & 4 \\
\hline 99 & 0 & $23,100,000$ & 24 & $3.75 \%$ & $1,477,000$ & $\begin{array}{l}\text { High } \\
\text { School }\end{array}$ & Married & Female & 37 & $\begin{array}{l}\text { hưởng } \\
\text { lương }\end{array}$ & $\begin{array}{l}\text { nhà } \\
\text { riêng }\end{array}$ & 3.7 & 1 & 6 & 6.7 & 3 & yes & 13 & 6 \\
\hline 100 & 0 & $23,100,000$ & 18 & $2.50 \%$ & $1,610,000$ & College & Married & Female & 33 & $\begin{array}{l}\text { TÜ } \\
\text { DOANH }\end{array}$ & $\begin{array}{l}\text { nhà } \\
\text { riêng }\end{array}$ & 20 & 0 & 2 & 6.7 & 3.5 & yes & 14 & 6 \\
\hline 101 & 0 & $23,100,000$ & 30 & $3.75 \%$ & $1,296,000$ & $\begin{array}{l}\text { Middle } \\
\text { School }\end{array}$ & Married & Female & 21 & $\begin{array}{l}\text { hưởng } \\
\text { lương }\end{array}$ & $\begin{array}{l}\text { nhà } \\
\text { riêng }\end{array}$ & 1 & 2 & 5 & 6.8 & 3.9 & yes & 12 & 4 \\
\hline 102 & 0 & $23,100,000$ & 24 & $3.75 \%$ & $1,477,000$ & $\begin{array}{l}\text { High } \\
\text { School }\end{array}$ & Single & Female & 23 & $\begin{array}{l}\text { TƯ } \\
\text { DOANH }\end{array}$ & THUÊ & 3 & 1 & 7 & 6.9 & 4 & YES & 5 & 5 \\
\hline 103 & 0 & $23,100,000$ & 24 & $5.01 \%$ & $1,675,000$ & $\begin{array}{l}\text { Middle } \\
\text { School }\end{array}$ & Married & Female & 39 & $\begin{array}{l}\text { hưởng } \\
\text { lương }\end{array}$ & $\begin{array}{l}\text { nhà } \\
\text { riêng }\end{array}$ & 6 & 1 & 3.9 & 7 & 3 & yes & 10 & 4 \\
\hline 104 & 0 & $23,100,000$ & 24 & $3.75 \%$ & $1,477,000$ & $\begin{array}{l}\text { Middle } \\
\text { School }\end{array}$ & Married & Female & 44 & $\begin{array}{l}\text { TƯ } \\
\text { DOANH }\end{array}$ & $\begin{array}{l}\text { nhà } \\
\text { riêng }\end{array}$ & 2 & 1 & 0.8 & 4.4 & 2.5 & yes & 7 & 6 \\
\hline 105 & 0 & $24,000,000$ & 36 & $2.92 \%$ & $1,086,000$ & $\begin{array}{l}\text { Middle } \\
\text { School }\end{array}$ & Married & Female & 28 & $\begin{array}{l}\text { TƯ } \\
\text { DOANH }\end{array}$ & $\begin{array}{l}\text { nhà } \\
\text { riêng }\end{array}$ & 10 & 4 & 0.3 & 4.1 & 3 & yes & 10 & 7 \\
\hline 106 & 0 & $24,150,000$ & 24 & $3.75 \%$ & $1,544,000$ & $\begin{array}{l}\text { Middle } \\
\text { School }\end{array}$ & Married & Male & 31 & $\begin{array}{l}\text { hưởng } \\
\text { lương }\end{array}$ & $\begin{array}{l}\text { nhà } \\
\text { riêng }\end{array}$ & 4 & 1 & 3 & 5.5 & 3 & yes & 8 & 7 \\
\hline 107 & 0 & $24,150,000$ & 18 & $3.76 \%$ & $1,870,000$ & $\begin{array}{l}\text { Middle } \\
\text { School }\end{array}$ & Married & Male & 31 & $\begin{array}{l}\text { hưởng } \\
\text { lương }\end{array}$ & THUÊ & 2 & 0 & 10 & 5.7 & 3.1 & yes & 13 & 6 \\
\hline 108 & 0 & $24,150,000$ & 24 & $5.00 \%$ & $1,751,000$ & $\begin{array}{l}\text { High } \\
\text { School }\end{array}$ & Married & Female & 31 & $\begin{array}{l}\text { hưởng } \\
\text { lương }\end{array}$ & $\begin{array}{l}\text { nhà } \\
\text { riêng }\end{array}$ & 8 & 2 & 5 & 4.8 & 2 & NO & 10 & 7 \\
\hline
\end{tabular}




\begin{tabular}{|c|c|c|c|c|c|c|c|c|c|c|c|c|c|c|c|c|c|c|c|}
\hline 109 & 0 & $24,150,000$ & 24 & $2.92 \%$ & $1,414,000$ & $\begin{array}{l}\text { Basic } \\
\text { School }\end{array}$ & Married & Female & 39 & $\begin{array}{l}\text { hưởng } \\
\text { lương }\end{array}$ & THUÊ & 4 & 2 & 1 & 4.9 & 2.5 & yes & 11 & 7 \\
\hline 110 & 0 & $24,150,000$ & 24 & $3.75 \%$ & $1,544,000$ & $\begin{array}{l}\text { Middle } \\
\text { School }\end{array}$ & Married & Male & 31 & $\begin{array}{l}\text { TƯ } \\
\text { DOANH }\end{array}$ & $\begin{array}{l}\text { nhà } \\
\text { riêng }\end{array}$ & 20 & 2 & 0.6 & 5.5 & 1.3 & yes & 8 & 4 \\
\hline 111 & 0 & $25,000,000$ & 19 & $4.60 \%$ & $2,001,000$ & $\begin{array}{l}\text { High } \\
\text { School }\end{array}$ & Married & Male & 37 & $\begin{array}{l}\text { hưởng } \\
\text { lương }\end{array}$ & THUÊ & 3 & 0 & 5 & 5.5 & 2 & yes & 13 & 6 \\
\hline 112 & 0 & $25,000,000$ & 36 & $2.92 \%$ & $1,131,000$ & Bachelor & Married & Male & 28 & $\begin{array}{l}\text { TỨ } \\
\text { DOANH }\end{array}$ & $\begin{array}{l}\text { nhà } \\
\text { riêng }\end{array}$ & 12 & 1 & 3 & 6.7 & 2 & $\mathrm{NO}$ & 14 & 6 \\
\hline 113 & 0 & $25,000,000$ & 36 & $2.92 \%$ & $1,131,000$ & $\begin{array}{l}\text { Middle } \\
\text { School }\end{array}$ & Married & Male & 29 & $\begin{array}{l}\text { TỬ } \\
\text { DOANH }\end{array}$ & THUÊ & 1 & 0 & 0.7 & 6.7 & 3.1 & yes & 12 & 4 \\
\hline 114 & 0 & $25,200,000$ & 24 & $5.00 \%$ & $1,827,000$ & $\begin{array}{l}\text { Middle } \\
\text { School }\end{array}$ & Married & Female & 43 & $\begin{array}{l}\text { hưởng } \\
\text { lương }\end{array}$ & $\begin{array}{l}\text { nhà } \\
\text { riêng }\end{array}$ & 20 & 0 & 5 & 6.8 & 2.6 & yes & 15 & 5 \\
\hline 115 & 0 & $25,200,000$ & 24 & $3.75 \%$ & $1,611,000$ & $\begin{array}{l}\text { High } \\
\text { School }\end{array}$ & Single & Male & 33 & $\begin{array}{l}\text { hưởng } \\
\text { lương }\end{array}$ & $\begin{array}{l}\text { nhà } \\
\text { riêng }\end{array}$ & 16 & 1 & 0.9 & 6.9 & 3 & yes & 10 & 4 \\
\hline 116 & 0 & $26,250,000$ & 36 & $3.75 \%$ & $1,341,000$ & $\begin{array}{l}\text { Middle } \\
\text { School }\end{array}$ & Other & Female & 38 & $\begin{array}{l}\text { TỬ } \\
\text { DOANH }\end{array}$ & $\begin{array}{l}\text { nhà } \\
\text { riêng }\end{array}$ & 24 & 0 & 6 & 7 & 4 & yes & 8 & 6 \\
\hline 117 & 0 & $26,250,000$ & 24 & $3.75 \%$ & $1,678,000$ & $\begin{array}{l}\text { High } \\
\text { School }\end{array}$ & Single & Male & 26 & $\begin{array}{l}\text { hưởng } \\
\text { lương }\end{array}$ & THUÊ & 1 & 1 & 4 & 5.6 & 2.1 & yes & 10 & 7 \\
\hline 118 & 0 & $26,250,000$ & 24 & $3.75 \%$ & $1,678,000$ & $\begin{array}{l}\text { Middle } \\
\text { School }\end{array}$ & Married & Male & 23 & $\begin{array}{l}\text { hưởng } \\
\text { lương }\end{array}$ & THUÊ & 2 & 1 & 0.5 & 4.1 & 2 & NO & 8 & 7 \\
\hline 119 & 0 & $26,250,000$ & 19 & $4.59 \%$ & $2,100,081$ & $\begin{array}{l}\text { Middle } \\
\text { School }\end{array}$ & Single & Male & 33 & $\begin{array}{l}\text { hưởng } \\
\text { lương }\end{array}$ & $\begin{array}{l}\text { nhà } \\
\text { riêng }\end{array}$ & 15 & 0 & 0.5 & 6.9 & 3.5 & NO & 10 & 6 \\
\hline 120 & 0 & $26,250,000$ & 27 & $4.59 \%$ & $1,715,591$ & $\begin{array}{l}\text { Middle } \\
\text { School }\end{array}$ & Married & Male & 25 & $\begin{array}{l}\text { TỬ } \\
\text { DOANH }\end{array}$ & $\begin{array}{l}\text { nhà } \\
\text { riêng }\end{array}$ & 2 & 1 & 0.4 & 5.7 & 2 & yes & 7 & 7 \\
\hline 121 & 0 & $26,250,000$ & 36 & $3.75 \%$ & $1,341,000$ & College & Single & Female & 23 & & THUÊ & 2 & 3 & 5 & 6.8 & 3 & yes & 10 & 7 \\
\hline 122 & 0 & $26,250,000$ & 24 & $3.75 \%$ & $1,678,000$ & $\begin{array}{l}\text { Middle } \\
\text { School }\end{array}$ & Widow/Widower & Female & 25 & $\begin{array}{l}\text { hưởng } \\
\text { lương }\end{array}$ & $\begin{array}{l}\text { nhà } \\
\text { riêng }\end{array}$ & 3 & 0 & 5 & 6.9 & 3.5 & yes & 8 & 4 \\
\hline 123 & 0 & $26,250,000$ & 36 & $3.75 \%$ & $1,341,000$ & $\begin{array}{l}\text { High } \\
\text { School }\end{array}$ & Married & Male & 44 & $\begin{array}{l}\text { TỬ } \\
\text { DOANH }\end{array}$ & THUÊ & 3 & 2 & 11 & 7 & 3.9 & YES & 13 & 6 \\
\hline 124 & 0 & $26,250,000$ & 24 & $5.00 \%$ & $1,903,000$ & $\begin{array}{l}\text { Middle } \\
\text { School }\end{array}$ & Married & Male & 33 & $\begin{array}{l}\text { hưởng } \\
\text { lương }\end{array}$ & $\begin{array}{l}\text { nhà } \\
\text { riêng }\end{array}$ & 5 & 0 & 5 & 4.4 & 2 & yes & 10 & 6 \\
\hline 125 & 0 & $26,375,000$ & 30 & $3.75 \%$ & $1,480,000$ & $\begin{array}{l}\text { High } \\
\text { School }\end{array}$ & Married & Female & 24 & $\begin{array}{l}\text { TƯ } \\
\text { DOANH }\end{array}$ & $\begin{array}{l}\text { nhà } \\
\text { riêng }\end{array}$ & 10 & 2 & 2 & 4.1 & 2 & yes & 11 & 4 \\
\hline 126 & 0 & $27,300,000$ & 24 & $3.75 \%$ & $1,745,000$ & $\begin{array}{l}\text { Basic } \\
\text { School }\end{array}$ & Married & Male & 37 & $\begin{array}{l}\text { TỬ } \\
\text { DOANH }\end{array}$ & $\begin{array}{l}\text { nhà } \\
\text { riêng }\end{array}$ & 15 & 1 & 2 & 5.5 & 2.5 & yes & 8 & 5 \\
\hline 127 & 0 & $27,357,419$ & 19 & $4.59 \%$ & $2,189,000$ & $\begin{array}{l}\text { High } \\
\text { School }\end{array}$ & Single & Male & 25 & $\begin{array}{l}\text { hưởng } \\
\text { lương }\end{array}$ & $\begin{array}{l}\text { nhà } \\
\text { riêng }\end{array}$ & 5 & 0 & 1 & 5.7 & 3.5 & yes & 13 & 4 \\
\hline
\end{tabular}




\begin{tabular}{|c|c|c|c|c|c|c|c|c|c|c|c|c|c|c|c|c|c|c|c|}
\hline 128 & 0 & $28,000,000$ & 36 & $3.75 \%$ & $1,430,000$ & $\begin{array}{l}\text { Middle } \\
\text { School }\end{array}$ & Married & Male & 45 & $\begin{array}{l}\text { hưởng } \\
\text { lương }\end{array}$ & THUÊ & 1 & 0 & 3 & 4.8 & 2 & yes & 14 & 6 \\
\hline 129 & 0 & $28,292,114$ & 24 & $4.59 \%$ & $1,970,000$ & $\begin{array}{l}\text { Middle } \\
\text { School }\end{array}$ & Married & Male & 40 & $\begin{array}{l}\text { hưởng } \\
\text { lương }\end{array}$ & $\begin{array}{l}\text { nhà } \\
\text { riêng }\end{array}$ & 2 & 0 & 1 & 8 & 3 & NO & 12 & 7 \\
\hline 130 & 0 & $28,350,000$ & 27 & $3.75 \%$ & $1,688,000$ & $\begin{array}{l}\text { High } \\
\text { School }\end{array}$ & Married & Male & 41 & $\begin{array}{l}\text { hưởng } \\
\text { lương }\end{array}$ & THUÊ & 4 & 1 & 3.6 & 5.5 & 3.5 & yes & 15 & 7 \\
\hline 131 & 0 & $28,350,000$ & 19 & $4.59 \%$ & $2,269,000$ & $\begin{array}{l}\text { Middle } \\
\text { School }\end{array}$ & Married & Female & 41 & $\begin{array}{l}\text { TƯ゙ } \\
\text { DOANH }\end{array}$ & $\begin{array}{l}\text { nhà } \\
\text { riêng }\end{array}$ & 20 & 0 & 8 & 5.5 & 2.9 & yes & 10 & 6 \\
\hline 132 & 0 & $28,980,340$ & 24 & $4.59 \%$ & $2,018,000$ & $\begin{array}{l}\text { Middle } \\
\text { School }\end{array}$ & Married & Male & 27 & $\begin{array}{l}\text { hưởng } \\
\text { lương }\end{array}$ & THUÊ & 2 & 0 & 2 & 7.9 & 3 & yes & 15 & 4 \\
\hline 133 & 0 & $29,319,920$ & 28 & $3.75 \%$ & $1,710,000$ & $\begin{array}{l}\text { Middle } \\
\text { School }\end{array}$ & Married & Female & 33 & $\begin{array}{l}\text { TƯ } \\
\text { DOANH }\end{array}$ & $\begin{array}{l}\text { nhà } \\
\text { riêng }\end{array}$ & 20 & 0 & 10 & 6.7 & 3 & $\mathrm{NO}$ & 10 & 5 \\
\hline 134 & 0 & $29,400,000$ & 30 & $3.75 \%$ & $1,649,000$ & $\begin{array}{l}\text { Middle } \\
\text { School }\end{array}$ & Married & Female & 25 & $\begin{array}{l}\text { TƯ } \\
\text { DOANH }\end{array}$ & THUÊ & 3 & 0 & 7 & 6.8 & 3 & yes & 8 & 4 \\
\hline 135 & 0 & $29,400,000$ & 36 & \#NUM! & $1,960,000$ & $\begin{array}{l}\text { Middle } \\
\text { School }\end{array}$ & Married & Female & 51 & $\begin{array}{l}\text { hưởng } \\
\text { lương }\end{array}$ & $\begin{array}{l}\text { nhà } \\
\text { riêng }\end{array}$ & 40 & 0 & 6 & 6.9 & 4 & yes & 10 & 6 \\
\hline 136 & 0 & $29,400,000$ & 30 & $3.75 \%$ & $1,649,000$ & $\begin{array}{l}\text { High } \\
\text { School }\end{array}$ & Married & Male & 27 & $\begin{array}{l}\text { hưởng } \\
\text { lương }\end{array}$ & $\begin{array}{l}\text { nhà } \\
\text { riêng }\end{array}$ & 3 & 1 & 3 & 7 & 4 & yes & 7 & 7 \\
\hline 137 & 0 & $29,827,790$ & 16 & $4.59 \%$ & $2,673,000$ & $\begin{array}{l}\text { Basic } \\
\text { School }\end{array}$ & Married & Male & 28 & $\begin{array}{l}\text { TỰ } \\
\text { DOANH }\end{array}$ & $\begin{array}{l}\text { nhà } \\
\text { riêng }\end{array}$ & 3 & 5 & 9 & 8.9 & 5 & yes & 10 & 7 \\
\hline 138 & 0 & $30,000,000$ & 30 & $3.75 \%$ & $1,683,000$ & $\begin{array}{l}\text { Middle } \\
\text { School }\end{array}$ & Married & Male & 23 & $\begin{array}{l}\text { hưởng } \\
\text { lương }\end{array}$ & THUÊ & 2 & 1 & 5 & 4.1 & 2.5 & yes & 8 & 6 \\
\hline 139 & 0 & $30,000,000$ & 36 & $2.92 \%$ & $1,358,000$ & $\begin{array}{l}\text { High } \\
\text { School }\end{array}$ & Married & Female & 26 & $\begin{array}{l}\text { hưởng } \\
\text { lương }\end{array}$ & THUÊ & 2 & 1 & 1 & 6.9 & 3.5 & $\mathrm{NO}$ & 13 & 7 \\
\hline 140 & 0 & $30,000,000$ & 24 & $3.75 \%$ & $1,918,000$ & $\begin{array}{l}\text { Middle } \\
\text { School }\end{array}$ & Married & Male & 33 & $\begin{array}{l}\text { hưởng } \\
\text { lương }\end{array}$ & $\begin{array}{l}\text { nhà } \\
\text { riêng }\end{array}$ & 33 & 0 & 2 & 8.7 & 4 & $\mathrm{NO}$ & 10 & 7 \\
\hline 141 & 0 & $30,450,000$ & 36 & $2.92 \%$ & $1,378,000$ & $\begin{array}{l}\text { Middle } \\
\text { School }\end{array}$ & Other & Female & 49 & $\begin{array}{l}\text { TƯ } \\
\text { DOANH }\end{array}$ & $\begin{array}{l}\text { nhà } \\
\text { riêng }\end{array}$ & 2 & 0 & 1 & 8 & 3 & yes & 11 & 4 \\
\hline 142 & 0 & $30,450,000$ & 24 & $3.75 \%$ & $1,947,000$ & $\begin{array}{l}\text { High } \\
\text { School }\end{array}$ & Single & Male & 23 & & THUÊ & 1 & 0 & 2 & 10 & 4.5 & yes & 8 & 6 \\
\hline 143 & 0 & $30,450,000$ & 24 & $3.75 \%$ & $1,947,000$ & $\begin{array}{l}\text { High } \\
\text { School }\end{array}$ & Married & Female & 30 & $\begin{array}{l}\text { hưởng } \\
\text { lương }\end{array}$ & $\begin{array}{l}\text { nhà } \\
\text { riêng }\end{array}$ & 1 & 1 & 2 & 11 & 5.9 & yes & 13 & 6 \\
\hline 144 & 0 & $30,823,030$ & 36 & $2.92 \%$ & $1,395,000$ & $\begin{array}{l}\text { Middle } \\
\text { School }\end{array}$ & Married & Female & 40 & $\begin{array}{l}\text { TƯ } \\
\text { DOANH }\end{array}$ & THUÊ & 5 & 0 & 5 & 6.4 & 3 & YES & 14 & 4 \\
\hline 145 & 0 & $31,500,000$ & 24 & $3.75 \%$ & $2,014,000$ & $\begin{array}{l}\text { Middle } \\
\text { School }\end{array}$ & Married & Male & 27 & $\begin{array}{l}\text { hưởng } \\
\text { lương }\end{array}$ & $\begin{array}{l}\text { nhà } \\
\text { riêng }\end{array}$ & 5 & 1 & 4 & 7 & 3 & yes & 12 & 5 \\
\hline 146 & 0 & $31,500,000$ & 36 & $2.50 \%$ & $1,338,000$ & $\begin{array}{l}\text { Basic } \\
\text { School }\end{array}$ & Married & Female & 46 & $\begin{array}{l}\text { TƯ } \\
\text { DOANH }\end{array}$ & $\begin{array}{l}\text { nhà } \\
\text { riêng }\end{array}$ & 15 & 2 & 3.9 & 7.8 & 3 & yes & 15 & 4 \\
\hline
\end{tabular}




\begin{tabular}{|c|c|c|c|c|c|c|c|c|c|c|c|c|c|c|c|c|c|c|c|}
\hline 147 & 0 & $31,500,000$ & 18 & $4.59 \%$ & $2,609,075$ & $\begin{array}{l}\text { Middle } \\
\text { School }\end{array}$ & Married & Male & 44 & $\begin{array}{l}\text { TỤ๋ } \\
\text { DOANH }\end{array}$ & $\begin{array}{l}\text { nhà } \\
\text { riêng }\end{array}$ & 5 & 1 & 0.8 & 9 & 4 & yes & 10 & 6 \\
\hline 148 & 0 & $31,500,000$ & 36 & $2.92 \%$ & $1,425,000$ & $\begin{array}{l}\text { High } \\
\text { School }\end{array}$ & Single & Male & 28 & $\begin{array}{l}\text { hưởng } \\
\text { lương }\end{array}$ & $\begin{array}{l}\text { nhà } \\
\text { riêng }\end{array}$ & 3 & 2 & 3 & 5.5 & 3 & yes & 15 & 7 \\
\hline 149 & 0 & $31,500,000$ & 36 & $2.92 \%$ & $1,425,000$ & Bachelor & Married & Female & 30 & $\begin{array}{l}\text { hưởng } \\
\text { lương }\end{array}$ & THUÊ & 0.7 & 2 & 3 & 5.7 & 3 & yes & 10 & 7 \\
\hline 150 & 0 & $31,500,000$ & 12 & $2.92 \%$ & $3,149,000$ & $\begin{array}{l}\text { Basic } \\
\text { School }\end{array}$ & Married & Male & 37 & $\begin{array}{l}\text { hưởng } \\
\text { lương }\end{array}$ & $\begin{array}{l}\text { nhà } \\
\text { riêng }\end{array}$ & 1 & 2 & 10 & 7.4 & 4 & $\mathrm{NO}$ & 8 & 5 \\
\hline 151 & 0 & $31,500,000$ & 24 & $2.92 \%$ & $1,844,000$ & $\begin{array}{l}\text { High } \\
\text { School }\end{array}$ & Single & Female & 20 & $\begin{array}{l}\text { hưởng } \\
\text { lương }\end{array}$ & THUÊ & 3 & 0 & 5 & 8 & 4 & yes & 10 & 5 \\
\hline 152 & 0 & $31,500,000$ & 30 & $3.75 \%$ & $1,767,000$ & $\begin{array}{l}\text { Middle } \\
\text { School }\end{array}$ & Single & Female & 30 & $\begin{array}{l}\text { TƯ } \\
\text { DOANH }\end{array}$ & $\begin{array}{l}\text { nhà } \\
\text { riêng }\end{array}$ & 1 & 0 & 1 & 5.5 & 2.5 & yes & 7 & 5 \\
\hline 153 & 0 & $31,500,000$ & 24 & $3.75 \%$ & $2,014,000$ & College & Single & Male & 30 & $\begin{array}{l}\text { hưởng } \\
\text { lương }\end{array}$ & THUÊ & 0.9 & 0 & 0.6 & 6.9 & 2.5 & yes & 10 & 6 \\
\hline 154 & 0 & $31,500,000$ & 36 & $2.92 \%$ & $1,425,000$ & $\begin{array}{l}\text { Middle } \\
\text { School }\end{array}$ & Married & Male & 34 & $\begin{array}{l}\text { TƯ } \\
\text { DOANH }\end{array}$ & $\begin{array}{l}\text { nhà } \\
\text { riêng }\end{array}$ & 10 & 1 & 5 & 7.9 & 3.5 & $\mathrm{NO}$ & 8 & 6 \\
\hline 155 & 0 & $31,500,000$ & 36 & $3.75 \%$ & $1,609,000$ & College & Married & Male & 44 & $\begin{array}{l}\text { TƯ } \\
\text { DOANH }\end{array}$ & THUÊ & 1 & 2 & 3 & 6.7 & 4 & yes & 13 & 7 \\
\hline 156 & 0 & $31,500,000$ & 24 & $5.00 \%$ & $2,283,000$ & $\begin{array}{l}\text { High } \\
\text { School }\end{array}$ & Married & Male & 36 & $\begin{array}{l}\text { hưởng } \\
\text { lương }\end{array}$ & $\begin{array}{l}\text { nhà } \\
\text { riêng }\end{array}$ & 10 & 2 & 3 & 8.1 & 3 & yes & 10 & 4 \\
\hline 157 & 0 & $31,500,000$ & 28 & $3.75 \%$ & $1,837,000$ & $\begin{array}{l}\text { High } \\
\text { School }\end{array}$ & Married & Female & 38 & $\begin{array}{l}\text { hưởng } \\
\text { lương }\end{array}$ & $\begin{array}{l}\text { nhà } \\
\text { riêng }\end{array}$ & 15 & 2 & 5 & 6.9 & 4 & yes & 11 & 6 \\
\hline 158 & 0 & $31,500,000$ & 12 & $5.00 \%$ & $3,555,000$ & $\begin{array}{l}\text { High } \\
\text { School }\end{array}$ & Married & Male & 40 & $\begin{array}{l}\text { TƯ } \\
\text { DOANH }\end{array}$ & $\begin{array}{l}\text { nhà } \\
\text { riêng }\end{array}$ & 17 & 0 & 3 & 8 & 3.5 & yes & 8 & 6 \\
\hline 159 & 0 & $31,500,000$ & 36 & $3.75 \%$ & $1,609,000$ & $\begin{array}{l}\text { Middle } \\
\text { School }\end{array}$ & Married & Female & 37 & $\begin{array}{l}\text { hưởng } \\
\text { lương }\end{array}$ & THUÊ & 3 & 0 & 6 & 8.9 & 3 & yes & 13 & 7 \\
\hline 160 & 0 & $31,500,000$ & 30 & $3.75 \%$ & $1,767,000$ & $\begin{array}{l}\text { Middle } \\
\text { School }\end{array}$ & Single & Female & 29 & $\begin{array}{l}\text { hưởng } \\
\text { lương }\end{array}$ & THUÊ & 0.6 & 0 & 4 & 4.1 & 2.5 & NO & 14 & 8 \\
\hline 161 & 0 & $31,500,000$ & 24 & $3.75 \%$ & $2,014,000$ & $\begin{array}{l}\text { High } \\
\text { School }\end{array}$ & Married & Male & 29 & $\begin{array}{l}\text { hưởng } \\
\text { lương }\end{array}$ & $\begin{array}{l}\text { nhà } \\
\text { riêng }\end{array}$ & 17 & 1 & 5 & 6.9 & 3 & $\mathrm{NO}$ & 12 & 7 \\
\hline 162 & 0 & $31,500,000$ & 24 & $3.75 \%$ & $2,014,000$ & $\begin{array}{l}\text { High } \\
\text { School }\end{array}$ & Married & Male & 34 & $\begin{array}{l}\text { TƯ } \\
\text { DOANH }\end{array}$ & $\begin{array}{l}\text { nhà } \\
\text { riêng }\end{array}$ & 3 & 0 & 4 & 8.7 & 4 & yes & 15 & 5 \\
\hline 163 & 0 & $31,650,000$ & 36 & $3.75 \%$ & $1,617,000$ & $\begin{array}{l}\text { Middle } \\
\text { School }\end{array}$ & Married & Female & 27 & & THUÊ & 1.5 & 2 & 4 & 8 & 3 & yes & 10 & 6 \\
\hline 164 & 0 & $33,600,000$ & 24 & $3.75 \%$ & $2,148,000$ & $\begin{array}{l}\text { Basic } \\
\text { School }\end{array}$ & Married & Male & 44 & $\begin{array}{l}\text { hưởng } \\
\text { lương }\end{array}$ & $\begin{array}{l}\text { nhà } \\
\text { riêng }\end{array}$ & 4 & 2 & 5 & 10 & 4 & yes & 15 & 7 \\
\hline 165 & 0 & $33,600,000$ & 24 & $4.59 \%$ & $2,338,830$ & $\begin{array}{l}\text { Middle } \\
\text { School }\end{array}$ & Married & Male & 51 & $\begin{array}{l}\text { TÜ } \\
\text { DOANH }\end{array}$ & THUÊ & 2 & 3 & 6 & 11 & 5 & YES & 11 & 5 \\
\hline
\end{tabular}




\begin{tabular}{|c|c|c|c|c|c|c|c|c|c|c|c|c|c|c|c|c|c|c|c|}
\hline 166 & 0 & $34,300,987$ & 36 & $3.75 \%$ & $1,752,000$ & $\begin{array}{l}\text { Basic } \\
\text { School }\end{array}$ & Married & Male & 38 & $\begin{array}{l}\text { hưởng } \\
\text { lương }\end{array}$ & $\begin{array}{l}\text { nhà } \\
\text { riêng }\end{array}$ & 3 & 0 & 1 & 6.4 & 4 & yes & 8 & 5 \\
\hline 167 & 0 & $34,329,569$ & 36 & $3.75 \%$ & $1,754,000$ & $\begin{array}{l}\text { High } \\
\text { School }\end{array}$ & Married & Female & 46 & $\begin{array}{l}\text { TƯ } \\
\text { DOANH }\end{array}$ & $\begin{array}{l}\text { nhà } \\
\text { riêng }\end{array}$ & 10 & 1 & 5 & 7 & 3 & yes & 12 & 6 \\
\hline 168 & 0 & $34,454,889$ & 36 & $3.75 \%$ & $1,760,000$ & $\begin{array}{l}\text { High } \\
\text { School }\end{array}$ & Single & Male & 41 & $\begin{array}{l}\text { TƯ } \\
\text { DOANH }\end{array}$ & $\begin{array}{l}\text { nhà } \\
\text { riêng }\end{array}$ & 13 & 1 & 2 & 7.8 & 4 & yes & 15 & 6 \\
\hline 169 & 0 & $34,472,568$ & 36 & $3.75 \%$ & $1,761,000$ & $\begin{array}{l}\text { Middle } \\
\text { School }\end{array}$ & Married & Female & 40 & $\begin{array}{l}\text { hưởng } \\
\text { lương }\end{array}$ & $\begin{array}{l}\text { nhà } \\
\text { riêng }\end{array}$ & 10 & 1 & 2 & 9 & 3.5 & yes & 10 & 6 \\
\hline 170 & 0 & $35,657,810$ & 19 & $4.59 \%$ & $2,853,000$ & $\begin{array}{l}\text { Middle } \\
\text { School }\end{array}$ & Married & Female & 34 & $\begin{array}{l}\text { hưởng } \\
\text { lương }\end{array}$ & THUÊ & 1 & 0 & 1 & 8 & 3 & yes & 15 & 6 \\
\hline 171 & 0 & $36,006,147$ & 19 & $4.59 \%$ & $2,881,000$ & $\begin{array}{l}\text { Middle } \\
\text { School }\end{array}$ & Single & Male & 23 & $\begin{array}{l}\text { hưởng } \\
\text { lương }\end{array}$ & $\begin{array}{l}\text { nhà } \\
\text { riêng }\end{array}$ & 3 & 0 & 3 & 5.5 & 2.5 & $\mathrm{NO}$ & 10 & 6 \\
\hline 172 & 0 & $36,750,000$ & 36 & $2.92 \%$ & $1,663,000$ & $\begin{array}{l}\text { High } \\
\text { School }\end{array}$ & Married & Male & 31 & $\begin{array}{l}\text { hưởng } \\
\text { lương }\end{array}$ & THUÊ & 4.3 & 1 & 1 & 6.9 & 3 & yes & 8 & 5 \\
\hline 173 & 0 & $36,750,000$ & 24 & $3.75 \%$ & $2,350,000$ & $\begin{array}{l}\text { Middle } \\
\text { School }\end{array}$ & Married & Male & 44 & $\begin{array}{l}\text { TƯ } \\
\text { DOANH }\end{array}$ & $\begin{array}{l}\text { nhà } \\
\text { riêng }\end{array}$ & 2 & 2 & 3.6 & 7.9 & 4 & yes & 7.9 & 4 \\
\hline 174 & 0 & $36,750,000$ & 24 & $3.75 \%$ & $2,350,000$ & $\begin{array}{l}\text { High } \\
\text { School }\end{array}$ & Married & Male & 26 & $\begin{array}{l}\text { hưởng } \\
\text { lương }\end{array}$ & THUÊ & 2 & 0 & 8 & 6.7 & 3 & yes & 6.7 & 3 \\
\hline 175 & 0 & $36,750,000$ & 24 & $3.75 \%$ & $2,350,000$ & $\begin{array}{l}\text { High } \\
\text { School }\end{array}$ & Single & Female & 24 & $\begin{array}{l}\text { TƯ } \\
\text { DOANH }\end{array}$ & $\begin{array}{l}\text { nhà } \\
\text { riêng }\end{array}$ & 2 & 1 & 2 & 8.1 & 4 & NO & 8.1 & 4 \\
\hline 176 & 0 & $39,900,000$ & 36 & $3.75 \%$ & $2,038,000$ & $\begin{array}{l}\text { High } \\
\text { School }\end{array}$ & Single & Female & 22 & $\begin{array}{l}\text { TƯ } \\
\text { DOANH }\end{array}$ & THUÊ & 0.5 & 0 & 0.9 & 6.9 & 3 & yes & 6.9 & 3 \\
\hline 177 & 0 & $39,900,000$ & 30 & $4.59 \%$ & $2,475,524$ & $\begin{array}{l}\text { High } \\
\text { School }\end{array}$ & Married & Male & 28 & $\begin{array}{l}\text { hưởng } \\
\text { lương }\end{array}$ & $\begin{array}{l}\text { nhà } \\
\text { riêng }\end{array}$ & 4 & 0 & 7 & 7 & 4 & yes & 7 & 4 \\
\hline 178 & 0 & $40,000,000$ & 36 & $2.92 \%$ & $1,810,000$ & College & Married & Male & 32 & $\begin{array}{l}\text { hưởng } \\
\text { lương }\end{array}$ & $\begin{array}{l}\text { nhà } \\
\text { riêng }\end{array}$ & 1 & 0 & 6 & 8.9 & 3 & yes & 8.9 & 3 \\
\hline 179 & 0 & $42,000,000$ & 36 & \#NUM! & $2,539,000$ & $\begin{array}{l}\text { High } \\
\text { School }\end{array}$ & Married & Female & 26 & $\begin{array}{l}\text { TÜ } \\
\text { DOANH }\end{array}$ & $\begin{array}{l}\text { nhà } \\
\text { riêng }\end{array}$ & 20 & 1 & 3 & 7.7 & 4 & yes & 7.7 & 4 \\
\hline 180 & 0 & $42,000,000$ & 36 & $3.75 \%$ & $2,145,000$ & $\begin{array}{l}\text { High } \\
\text { School }\end{array}$ & Married & Male & 26 & $\begin{array}{l}\text { hưởng } \\
\text { lương }\end{array}$ & THUÊ & 0.1 & 0 & 9 & 6.9 & 5 & yes & 10 & 6 \\
\hline 181 & 0 & $42,000,000$ & 36 & $2.92 \%$ & $1,900,000$ & $\begin{array}{l}\text { High } \\
\text { School }\end{array}$ & Married & Female & 38 & $\begin{array}{l}\text { hưởng } \\
\text { lương }\end{array}$ & THUÊ & 0.9 & 0 & 14 & 8.7 & 4 & NO & 15 & 6 \\
\hline 182 & 0 & $42,000,000$ & 36 & $2.92 \%$ & $1,900,000$ & College & Married & Female & 25 & $\begin{array}{l}\text { hưởng } \\
\text { lương }\end{array}$ & $\begin{array}{l}\text { nhà } \\
\text { riêng }\end{array}$ & 5 & 2 & 1 & 8 & 3 & NO & 10 & 6 \\
\hline 183 & 0 & $42,000,000$ & 30 & $2.50 \%$ & $2,007,000$ & College & Married & Female & 48 & $\begin{array}{l}\text { TƯ } \\
\text { DOANH }\end{array}$ & $\begin{array}{l}\text { nhà } \\
\text { riêng }\end{array}$ & 48 & 3 & 2 & 10 & 4 & yes & 8 & 5 \\
\hline 184 & 0 & $42,000,000$ & 24 & $2.92 \%$ & $2,458,000$ & $\begin{array}{l}\text { Middle } \\
\text { School }\end{array}$ & Divorced & Female & 31 & $\begin{array}{l}\text { TƯ } \\
\text { DOANH }\end{array}$ & THUÊ & 0.8 & 1 & 1 & 11 & 3.5 & yes & 12 & 7 \\
\hline
\end{tabular}




\begin{tabular}{|c|c|c|c|c|c|c|c|c|c|c|c|c|c|c|c|c|c|c|c|}
\hline 185 & 0 & $42,000,000$ & 36 & $2.92 \%$ & $1,900,000$ & College & Married & Male & 58 & $\begin{array}{l}\text { hưởng } \\
\text { lương }\end{array}$ & $\begin{array}{l}\text { nhà } \\
\text { riêng }\end{array}$ & 5 & 2 & 2 & 8.3 & 3 & yes & 7 & 4 \\
\hline 186 & 0 & $42,000,000$ & 36 & $2.92 \%$ & $1,900,000$ & Bachelor & Married & Female & 33 & $\begin{array}{l}\text { TỬ } \\
\text { DOANH }\end{array}$ & THUÊ & 0.9 & 2 & 2 & 7 & 4.5 & YES & 10 & 6 \\
\hline 187 & 0 & $42,218,706$ & 36 & $2.92 \%$ & $1,910,000$ & $\begin{array}{l}\text { High } \\
\text { School }\end{array}$ & Single & Female & 23 & $\begin{array}{l}\text { hưởng } \\
\text { lương }\end{array}$ & $\begin{array}{l}\text { nhà } \\
\text { riêng }\end{array}$ & 1 & 0 & 5 & 7.8 & 3 & yes & 8 & 4 \\
\hline 188 & 0 & $44,139,589$ & 36 & \#NUM! & $2,529,000$ & $\begin{array}{l}\text { High } \\
\text { School }\end{array}$ & Married & Female & 41 & $\begin{array}{l}\text { TƯ゙ } \\
\text { DOANH }\end{array}$ & $\begin{array}{l}\text { nhà } \\
\text { riêng }\end{array}$ & 41 & 3 & 7 & 9 & 4 & yes & 13 & 5 \\
\hline 189 & 0 & $45,150,000$ & 36 & $3.75 \%$ & $2,306,000$ & $\begin{array}{l}\text { Basic } \\
\text { School }\end{array}$ & Married & Male & 49 & $\begin{array}{l}\text { TỬ } \\
\text { DOANH }\end{array}$ & $\begin{array}{l}\text { nhà } \\
\text { riêng }\end{array}$ & 49 & 1 & 3.9 & 10 & 3 & yes & 10 & 3 \\
\hline 190 & 0 & $47,250,000$ & 36 & $2.92 \%$ & $2,138,000$ & $\begin{array}{l}\text { Middle } \\
\text { School }\end{array}$ & Married & Female & 41 & $\begin{array}{l}\text { hưởng } \\
\text { lương }\end{array}$ & $\begin{array}{l}\text { nhà } \\
\text { riêng }\end{array}$ & 10 & 1 & 0.8 & 9.8 & 4 & yes & 11 & 5 \\
\hline 191 & 0 & $47,250,000$ & 18 & $2.92 \%$ & $3,412,000$ & $\begin{array}{l}\text { High } \\
\text { School }\end{array}$ & Married & Male & 29 & $\begin{array}{l}\text { hưởng } \\
\text { lương }\end{array}$ & THUÊ & 0.8 & 0 & 10 & 11 & 3 & yes & 8 & 5 \\
\hline 192 & 0 & $50,000,000$ & 36 & $2.92 \%$ & $2,262,000$ & $\begin{array}{l}\text { Working } \\
\text { Cerfiticate }\end{array}$ & Married & Male & 53 & $\begin{array}{l}\text { hưởng } \\
\text { lương }\end{array}$ & $\begin{array}{l}\text { nhà } \\
\text { riêng }\end{array}$ & 20 & 0 & 3 & 8.8 & $\underline{4}$ & $\mathrm{NO}$ & 13 & 4 \\
\hline 193 & 0 & $52,500,000$ & 30 & $3.75 \%$ & $2,945,000$ & $\begin{array}{l}\text { High } \\
\text { School }\end{array}$ & Married & Male & 45 & $\begin{array}{l}\text { hưởng } \\
\text { lương }\end{array}$ & THUÊ & 0.9 & 2 & 10 & 9.4 & 4.5 & yes & 14 & 7 \\
\hline 194 & 0 & $52,500,000$ & 24 & $3.75 \%$ & $3,356,000$ & College & Married & Female & 49 & $\begin{array}{l}\text { TỤ } \\
\text { DOANH }\end{array}$ & $\begin{array}{l}\text { nhà } \\
\text { riêng }\end{array}$ & 20 & 0 & 5 & 12 & 5 & yes & 12 & 5 \\
\hline 195 & 0 & $52,500,000$ & 36 & $3.75 \%$ & $2,682,000$ & $\begin{array}{l}\text { High } \\
\text { School }\end{array}$ & Married & Male & 34 & $\begin{array}{l}\text { hưởng } \\
\text { lương }\end{array}$ & THUÊ & 5 & 2 & 1 & 14 & 7 & yes & 15 & 8 \\
\hline 196 & 0 & $52,500,000$ & 36 & $2.92 \%$ & $2,375,000$ & $\begin{array}{l}\text { Master } \\
\text { Degree }\end{array}$ & Married & Male & 37 & $\begin{array}{l}\text { TƯ } \\
\text { DOANH }\end{array}$ & $\begin{array}{l}\text { nhà } \\
\text { riêng }\end{array}$ & 10 & 3 & 0.6 & 20 & 10 & NO & 20 & 10 \\
\hline 197 & 0 & $52,500,000$ & 36 & $2.92 \%$ & $2,375,000$ & $\begin{array}{l}\text { Middle } \\
\text { School }\end{array}$ & Married & Female & 25 & $\begin{array}{l}\text { TỬ } \\
\text { DOANH }\end{array}$ & THUÊ & 0.5 & 0 & 5 & 15 & 7 & yes & 15 & 7 \\
\hline 198 & 0 & $52,500,000$ & 36 & $2.92 \%$ & $2,375,000$ & College & Single & Male & 27 & $\begin{array}{l}\text { hưởng } \\
\text { lương }\end{array}$ & $\begin{array}{l}\text { nhà } \\
\text { riêng }\end{array}$ & 1 & 0 & 3 & 16.7 & 6 & yes & 20 & 8 \\
\hline 199 & 0 & $52,500,000$ & 24 & $2.92 \%$ & $3,073,000$ & $\begin{array}{l}\text { High } \\
\text { School }\end{array}$ & Married & Male & 43 & $\begin{array}{l}\text { hưởng } \\
\text { lương }\end{array}$ & $\begin{array}{l}\text { nhà } \\
\text { riêng }\end{array}$ & 4 & 0 & 10 & 10 & 3 & yes & 15 & 8 \\
\hline 200 & 0 & $55,000,000$ & 24 & $2.50 \%$ & $3,076,000$ & College & Married & Female & 44 & $\begin{array}{l}\text { TƯ } \\
\text { DOANH }\end{array}$ & $\begin{array}{l}\text { nhà } \\
\text { riêng }\end{array}$ & 5 & 1 & 5 & 12 & 3 & yes & 15 & 8 \\
\hline 201 & 0 & $55,650,000$ & 36 & $2.92 \%$ & $2,518,000$ & $\begin{array}{l}\text { Middle } \\
\text { School }\end{array}$ & Married & Female & 42 & $\begin{array}{l}\text { hưởng } \\
\text { lương }\end{array}$ & $\begin{array}{l}\text { nhà } \\
\text { riêng }\end{array}$ & 7 & 2 & 12 & 14 & 5 & yes & 20 & 6 \\
\hline 202 & 0 & $57,750,000$ & 36 & $2.92 \%$ & $2,613,000$ & Bachelor & Married & Male & 37 & $\begin{array}{l}\text { TƯ } \\
\text { DOANH }\end{array}$ & THUÊ & 0.6 & 3 & 6 & 15 & 6 & YES & 18 & 8 \\
\hline 203 & 0 & $57,750,000$ & 36 & $2.92 \%$ & $2,613,000$ & $\begin{array}{l}\text { High } \\
\text { School }\end{array}$ & Married & Male & 63 & $\begin{array}{l}\text { hưởng } \\
\text { lương }\end{array}$ & $\begin{array}{l}\text { nhà } \\
\text { riêng }\end{array}$ & 19 & 1 & 4 & 20 & 8 & yes & 20 & 8 \\
\hline
\end{tabular}




\begin{tabular}{|c|c|c|c|c|c|c|c|c|c|c|c|c|c|c|c|c|c|c|c|}
\hline 204 & 0 & $59,198,855$ & 36 & $3.75 \%$ & $3,024,000$ & College & Married & Female & 54 & $\begin{array}{l}\text { TƯ } \\
\text { DOANH }\end{array}$ & $\begin{array}{l}\text { nhà } \\
\text { riêng }\end{array}$ & 19 & 0 & 20 & 22 & 10 & yes & 25 & 11 \\
\hline 205 & 0 & $64,315,352$ & 36 & $2.92 \%$ & $2,910,000$ & Bachelor & Married & Female & 32 & $\begin{array}{l}\text { TƯ⿱ } \\
\text { DOANH }\end{array}$ & $\begin{array}{l}\text { nhà } \\
\text { riêng }\end{array}$ & 18 & 0 & 15 & 20 & 5 & yes & 20 & 5 \\
\hline 206 & 0 & $65,100,000$ & 36 & $2.50 \%$ & $2,764,000$ & $\begin{array}{l}\text { High } \\
\text { School }\end{array}$ & Married & Female & 35 & $\begin{array}{l}\text { hưởng } \\
\text { lương }\end{array}$ & $\begin{array}{l}\text { nhà } \\
\text { riêng }\end{array}$ & 4 & 0 & 12 & 22 & 10 & yes & 22 & 10 \\
\hline 207 & 0 & $65,835,700$ & 36 & $2.92 \%$ & $2,979,000$ & $\begin{array}{l}\text { Working } \\
\text { Cerfiticate }\end{array}$ & Married & Female & 29 & $\begin{array}{l}\text { hưởng } \\
\text { lương }\end{array}$ & THUÊ & 4 & 1 & 17 & 24 & 7 & yes & 24 & 7 \\
\hline
\end{tabular}




\section{CHU'ONG 1 \\ TỔNG QUAN ĐỀ TÀI NGHIÊN CÚ̉U}

\subsection{Tính cấp thiết của đề tài}

Trong bối cảnh kinh tế xã hội có nhiều diễn biến phức tạp như hiện nay, ngân hàng thương mại luôn là định chế tài chính quan trọng nhất trên thị trường. Với vai trò là một cầu nối, ngân hàng thương mại huy động nguồn tiền nhàn rỗi trong xã hội và cho vay để đáp ứng các nhu cầu về vốn trên thị trường, từ đó tạo ra lợi nhuận do chênh lệch lãi suất. Nếu như hoạt động huy động vốn được xem là công cụ để kiểm soát lượng tiền trong lưu thông, kiềm chế lạm phát, thích thích nhu cầu tiết kiệm trong xã hội thì ngược lại, hoạt động tín dụng được sử dụng để kích cầu nền kinh tế, đáp ứng nhu cầu đầu tư, phát triển cơ sở hạ tầng, sản xuất kinh doanh, tiêu dùng của xã hội. Không chỉ đóng vai trò trong việc mang lại nguồn lợi nhuận cơ bản cho ngân hàng, hoạt động tín dụng còn mang ý nghĩa quyết định đến sự phát triển của một nền kinh tế.

Nếu như giai đoạn trước khủng hoảng, các ngân hàng chủ yếu tập trung cho vay doanh nghiệp theo hình thức bán buôn, thì sau khủng hoảng, các ngân hàng đã thay đổi chiến lược, và định hướng trở thành ngân hàng bán lẻ. Cụ thể là từ cuối 2012 đến nay, tín dụng cá nhân tại nhiều ngân hàng có xu hướng phát triển mạnh mẽ và là một thị trường đầy tiềm năng được chú trọng khai thác. Với đặc điểm là khoản vay nhỏ nhưng số lượng rất lớn, sản phẩm đa dạng và lãi suất cao, tín dụng cá nhân đã mang lại nguồn lợi nhuận rất lớn cho các ngân hàng trong giai đoạn hiện nay. Mặt khác, tín dụng cá nhân mang lại cho khách hàng sự thoả mãn nhu cầu tiêu dùng, kinh doanh trước khi họ có đủ khả năng chi trả, nâng cao mức sống người dân về vật chất, từ đó còn góp phần kích cầu, làm tăng trưởng nền kinh tế. Tuy nhiên, đi kèm với lợi nhuận thì rủi ro từ hoạt động này cũng rất lớn và cần phải được quản lý một cách hiệu quả.

Với định hướng trở thành một trong 3 ngân hàng bán lẻ hàng đầu Việt Nam trong năm 2017, Ngân hàng thương mại cổ phần (TMCP) Việt Nam Thịnh Vượng (VPBank) cũng đã và đang tích cực phát triển mạng lưới tín dụng cá nhân trên toàn 
quốc. Với các sản phẩm cho vay đa dạng, đội ngũ tư vấn nhiệt tình, quy trình phê duyệt hợp lý và đa dạng kênh giải ngân, kênh thanh toán cho khách hàng,tín dụng cá nhân đã không ngừng mở rộng quy mô hoạt động. Tuy nhiên, số lượng phải đi đôi với đảm bảo chất lượng. Yêu cầu ra quyết định tín dụng nhanh nhưng phải chuẩn xác và hạn chế rủi ro ở mức thấp nhất, đó là mục tiêu để phát triển lâu dài của tố chức.

Nếu như các sản phẩm cho vay mua bất động sản, cho vay cá nhân xây dựng sửa chửa nhà, cho vay mua ô tô, xe máy thường ít rủi ro hơn, vì có chính bất động sản hay tài sản làm vật đảm bảo, đối với những khoản vay cho khách hàng cá nhân kinh doanh cũng ít rủi ro hơn vì được thẩm định kỹ những tài liệu báo cáo thuế hoặc báo cáo tài chính, nhưng riêng với những khoản vay tín dụng cá nhân không có tài sản đảm bảo thì rủi ro sẽ cao hơn vì quy trình tín dụng thiên về định tính, phụ thuộc nhiều vào ý kiến chủ quan của cán bộ tín dụng, lại hoàn toàn không có tài sản đảm bảo. Trái lại, tâm lý người dân lại có xu hướng thích vay tiền mặt không có tài sản đảm bảo hơn là vay cầm cố nhà cửa, mua hàng hoá trả góp, và số lượng hợp đồng tín dụng cá nhân không có tài sản đảm bảo ngày càng tăng cao. Vậy vấn đề làm sao để đảm bảo chất lượng của những khoản vay không có tài sản đảm bảo này, hay nói cách khác là làm sao để hạn chế những rủi ro từ hình thức tín dụng này, đó là một vấn đề hết sức cấp bách tại mảng tín dụng cá nhân vay tiền mặt ngân hàng VPBank.

Xuất phát từ thực tiễn nêu trên, tác giả quyết định chọn đề tài: "Úng dụng $\boldsymbol{m} \hat{\boldsymbol{o}}$

\section{hình Binary Logistic vào phân tích rủi ro tín dụng cá nhân không có tài sản đảm} bảo tại Ngân hàng VPBank"

\subsection{Tình hình nghiên cứu đề tài}

(1) Trương Đông Lộc và Nguyễn Thị Tuyết (2011), Các nhân tố ảnh hưởng đến rủi ro tín dụng của ngân hàng thương mại cổ phần ngoại thương chi nhánh Cần Thơ, Tạp chí Ngân hàng, số 5, tháng 3, năm 2011, trang 38-41

Với mục đích xác định các nhân tố ảnh hưởng đến rủi ro tín dụng của Ngân hàng thương mại cổ phần Ngoại thương chi nhánh TP Cần Thơ, tác giả đã nghiên cứu trên 438 khách hàng từ thời điểm 1/1/2009 đến 31/12/2009. Trong bài viết này, tác giả nghiên cứu trên 2 nhóm khách hàng: cá nhân và doanh nghiệp. Sử dụng mô hình xác suất propit, tác giả xác định được các nhân tố ảnh hưởng đến rủi ro tín dụng của Ngân hàng thương mại cổ phần Ngoại thương chi nhánh TP Cần Thơ bao gồm: khả năng tài 
chính của khách hàng, mục đích sử dụng vốn vay, kinh nghiệm của cán bộ tín dụng,đa dạng hoá hoạt động kinh doanh, kiểm tra giám sát khoản vay. Từ kết quả nghiên cứu trên, đã cung cấp những bằng chứng thực tế có giá trị giúp cho các ngân hàng nói chung và ngân hàng TMCP Ngoại thương nói riêng hiểu rõ hơn các nguyên nhân dẫn đến rủi ro tín dụng, từ đó sẽ chủ động đưa ra các giải pháp phù hợp nhằm hạn chế rủi ro tín dụng.

(2) Vương Quân Hoàng, Đào Gia Hưng, Nguyễn Văn Hữu, Trần Minh Ngọc và Lê Hồng Phương (2006), Phương pháp thống kê xây dựng mô hình định mức tín nhiệm khách hàng thể nhân, Tạp chí ứng dụng toán học, tập 4, số 2, 2006

Trong nghiên cứu này, tác giả lấy mẫu quan sát là 1728 khách hàng của $\mathrm{NH}$ Techcombank, trong đó có 1374 thuộc nhóm tốt và 354 khách hàng thuộc nhóm không tốt. Tác giả sử dụng mô hình hồi quy Logistics, từ đó xác định được các nhân tố ảnh hưởng đến rủi ro tín dụng cá nhân bao gồm: tuổi tác, trình độ học vấn, loại hình công việc, thu nhập hàng tháng, tình trạng hôn nhân, nơi cư trú, thời gian cư trú, số người phụ thuộc, phương tiện đi lại, phương tiện thông tin, chênh lệch thu nhập và chi tiêu, giá trị tài sản khách hàng, giá trị các khoản nợ, quan hệ với Techcombank.

(3) Đỗ Thị Thu Quỳnh (2013), Một số giải pháp hạn chế rủi ro tín dụng tại Ngân hàng TMCP Công Thương Việt Nam - chi nhánh 1 TP HCM, Đại học kinh tế TP HCM, Luận văn thạc sĩ.

Với mục tiêu nhằm hạn chế rủi ro tín dụng tại ngân hàng TMCP Công thương Việt Nam - Chi nhánh 1 TP HCM, tác giả đã tiến hành nghiên cứu các lý thuyết về rủi ro tín dụng, cùng với việc phân tích thực trạng rủi ro tín dụng và công tác quản trị rủi ro tín dụng tại ngân hàng TMCP Công thương Việt Nam - Chi nhánh 1 TP HCM. Dựa trên việc phân tích các báo cáo tài chính, các tài liệu nội bộ trong khoảng thời gian từ 2009 - 2012 kết hợp với khảo sát thực tế. Từ đó đưa ra các kiến nghị, cũng như giải pháp cụ thể để góp phần hạn chế chế rủi ro tín dụng tại ngân hàng TMCP Công thương Việt Nam - Chi nhánh 1 TP HCM.

(4) Nguyễn Anh Dũng (2012) - Quản trị rủi ro tín dụng tại chi nhánh ngân hàng đầu tư và phát triển Bình Định, Đại học Đà Nẵng, Luận văn thạc sĩ.

Với mục tiêu đề xuất những giải pháp, đồng thời kiến nghị liên quan nhằm hoàn thiện công tác quản trị rủi ro tín dụng tại BIDV Bình Định, tác giả đã tiến hành 
nghiên cứu toàn bộ các vấn đề liên quan đến ro tín dụng tại BIDV Bình Định trên phương pháp tiếp cận bốn nội dung của quá trình quản trị rủi ro bao gồm nhận dạng, đo lường, kiểm soát và tài trợ rủi ro.

(5) Nguyễn Phúc Thế Đức (2008) - Hoàn thiện hệ thống chấm điểm xếp loại khách hàng nhằm giảm thiểu rủi ro tín dụng tại ngân hàng đầu tư và phát triển Việt Nam, trường ĐH Kinh tế TP Hồ Chí Minh, Luận văn thạc sĩ.

Trong nghiên cứu này, tác giả chủ yếu dựa vào phương pháp định tính để nghiên cứu các vấn đề lý luận và thực tiễn của hoạt động tín dụng, quản trị rủi ro tín dụng thông qua hệ thống xếp hạng tín dụng nội bộ. Từ đó nhằm đề xuất các giải pháp hạn chế rủi ro tín dụng tại hệ thống ngân hàng Đầu tư và phát triển Việt Nam. Tác giả chủ yếu nghiên cứu trên cơ sở số liệu báo cáo từ năm 2002 đến tháng 6/2007 để phân tích thực trạng rủi ro tín dụng và thực trạng xếp hạng tín dụng nội bộ tại hệ thống ngân hàng Đầu tư và phát triển Việt Nam. Từ đó tác giả đưa ra những đánh giá về các mặt tích cực, mặt hạn chế và đề xuất những nhóm giải pháp cụ thể để hoàn hiện hệ thống xếp hạng tín dụng nội bộ tại ngân hàng Đầu tư và phát triển Việt Nam.

(6) Trần Thị Thanh Thảo (2010), Giải pháp hạn chế rủi ro tín dụng tại chi nhánh ngân hàng thương mại cổ phần ngoại thương Đà Nẵng, Đại học Đà Nẵng, Luận văn thạc sĩ.

Trên cơ sở nghiên cứu hoạt động tín dụng tại ngân hàng TMCP Ngoại thương chi nhánh Đà Nẵng trong thời gian 2007-2009, tác giả đã tìm hiểu thực trạng và các nguyên nhân dẫn đến rủi ro tín dụng. Từ đó, tác giả đưa ra các nhóm giải pháp cụ thể nhằm hạn chế rủi ro tín dụng bao gồm: hoàn thiện hệ thống chẩm điểm tín dụng nội bộ, nhóm giải pháp về giám sát và kiểm soát rủi ro, nhóm giải pháp tài trợ rủi ro, nhóm giải pháp nhằm hoàn thiện và củng cố hệ thống thông tin tín dụng nội bộ, và giải pháp về nhân sự.

\subsection{Mục tiêu và câu hỏi nghiên cứu của đề tài}

\subsubsection{Mục tiêu:}

Từ việc phân tích thực trạng rủi ro tín dụng cá nhân không có tài sản đảm bảo tại VPBank, xác định các yếu tố ảnh hưởng đến rủi ro tín dụng cá nhân không có tài sản đảm bảo tại VPBank. 
Xây dựng mô hình dự báo rủi ro, xác định xác suất trả nợ của của $\mathrm{KH}$ vay vốn không có tài sản đảm bảo với mô hình hồi quy Binary Logostic.

Đề xuất, gợi ý các giải pháp nhằm hạn chế rủi ro tín dụng cá nhân không có tài sản đảm bảo từ việc ứng dụng mô hình hồi quy Binary Logostic.

\subsubsection{Câu hỏi nghiên cứu:}

1) Thực trạng rủi ro tín dụng cá nhân không có tài sản đảm bảo tại VPBamk như thế nào? Các yếu tố nào ảnh hưởng đến rủi ro tín dụng cá nhân không có tài sản đảm bảo tại VPBank?

2) Xác xuất trả được nợ của khách hàng cá nhân không có tài sản đảm bảo tại VPBank thông qua mô hình hồi quy Binary Logostic được xác định như thế nào?

3) Giải pháp nào để hạn chế rủi ro tín dụng cá nhân không có tài sản đảm bảo tại VPBank?

\section{4 Đối tượng và phạm vi nghiên cứu}

\subsection{1 Đối tượng nghiên cứu:}

Đối tượng nghiên cứu của luận văn là rủi ro tín dụng cá nhân không có tài sản đảm bảo tại VPBank.

\subsubsection{Phạm vi nghiên cứu:}

Về nội dung nghiên cứu: Đề tài tập trung nghiên cứu các vấn đề liên quan đến rủi ro tín dụng cá nhân không có tài sản đảm bảo tại VPBank.

Về không gian nghiên cứu: Đề tài tập trung nghiên cứu những khách hàng cá nhân, đang vay không có tài sản đảm bảo tại VPBank trên tất cả các chi nhánh.

Về phạm vi thời gian: Đề tài chỉ nghiên cứu những khách hàng có phát sinh khoản vay trong khoảng 6/2012 đến 12/2014.

\subsection{Phương pháp nghiên cứu}

Xuyên suốt luận văn chủ yếu sử dụng phương pháp định lượng, mô hình hồi quy Logistic để phân tích dữ liệu thứ cấp.

Bên cạnh đó, luận văn cũng kết hợp một phần phân tích, tổng hợp, so sánh, nhận xét đánh giá những yếu tố tác động đến rủi ro tín dụng tiêu dùng không có tài sản đảm bảo tại VPBank. 
Đề tài nghiên cứu thực hiện thông qua hai giai đoạn, nghiên cứu sơ bộ và nghiên cứu chính thức.

- Nghiên cứu sơ bộ sử dụng chủ yếu các kỹ thuật nghiên cứu như sau mô tả, phân tích, tổng hợp, so sánh để phân tích các chỉ tiêu đánh giá rủi ro tín dụng tại VPBank. Đánh giá về quy trình quản lý rủi ro, thẩm định tín dụng cá nhân tại VPBank, đưa ra những nhận định làm nền tảng để thiết kế các biến độc lập trong mô hình định lượng.

- Nghiên cứu chính thức được Tiến hành bằng việc nhằm thu thập thông tin ở dạng con số, và giải quyết quan hệ trong lý thuyết và nghiên cứu theo quan điểm diễn dịch.

Nghiên cứu định lượng có thể lượng hóa được thành con số cụ thể, phục vụ đo lường và phân tích các khái niệm nghiên cứu. Thông tin trả lời cho các câu hỏi: Bao nhiêu? như thế nào?

Dữ liệu nghiên cứu là dữ liệu thứ cấp được thu thập từ thông tin trong hồ sơ vay vốn của khách hàng, cộng với lịch sử thanh toán tại VPbank, từ đó tiến hành mã hoá thành số liệu của các biến và chạy mô hình hồi quy.

Phần mềm Eview 7 được sử dụng xuyên suốt trong toàn bộ quá trình nghiên cứu để phân tích dữ liệu.

\section{6 Ý nghĩa khoa học và thực tiễn của đề tài}

\subsection{1 Ý nghĩa khoa học}

Kiểm định mô hình hồi quy Binary Logistic trong phân tích các yếu tố ảnh hưởng đến rủi ro tín dụng cá nhân không có tài sản đảm bảo.

\subsection{2 Ý nghĩa thực tiễn}

Góp thêm cho mảng tín dụng cá nhân VPBank một công cụ để tính xác suất rủi ro khách hàng không trả được nợ một cách nhanh chóng, giảm bớt thời gian và áp lực cho bộ phận thẩm định.

Cung cấp cho mảng tín dụng cá nhân VPBank một vài gợi ý chính sách để nâng cao hiệu quả hoạt động bằng cách giảm thiểu rủi ro.

\subsection{Bố cục của luận văn}

Nghiên cứu bao gồm 5 chương với bố cục như sau:

Chương 1: Tổng quan về đề tài nghiên cứu 
Chương 2: Cơ sở lý thuyết và mô hình nghiên cứu

Chương 3: Thiết kế nghiên cứu

Chương 4: Kết quả nghiên cứu và thảo luận

Chương 5: Kết luận và gợi ý giải pháp

\section{Tóm lược chương 1}

Nội dung chương 1 đã trình bày một cách tổng quan, khát quát toàn bộ đề tài nghiên cứu bao gồm lý do chọn đề tài, mục tiêu nghiên cứu, phương pháp nghiên cứu, cũng như mô tả sơ lược tình hình nghiên cứu của đề tài. Bên cạnh đó, chương 1 cũng trình bày khái quát về bố cục chính của luận văn. 


\section{CHƯ'NG 2 \\ CƠ SỞ LÝ THUYẾT VÀ MÔ HÌNH NGHIÊN CÚU}

\subsection{Cơ sở lý thuyết}

\subsubsection{Tổng quan về tín dụng khách hàng cá nhân}

\subsubsection{Khái niệm về tín dụng khách hàng cá nhân}

- Khái niệm tín dụng

Theo Luật các tổ chức tín dụng năm 2010 đã được quốc hội thông qua thì: “Cấp tín dụng là việc thoả thuận để tổ chức, cá nhân sử dụng một khoản tiền hoặc cam kết sử dụng một khoản tiền hoặc cam kết cho phép sử dụng một khoản tiền theo nguyên tắc có hoàn trả bằng nghiệp vụ cho vay, chiết khấu, cho thuê tài chính, bao thanh toán, bảo lãnh ngân hàng và các nghiệp vụ cấp tín dụng khác”

- Khái niệm tín dụng cá nhân

Theo Nguyễn Lê Ngọc Ca (2011), tín dụng dụng cá nhân là hính thức tín dụng mà trong đó NHTM đóng vai trò là người chuyển nhượng quyền sử dụng vốn của mình cho khách hàng cá nhân hoặc hộ gia đình sử dụng trong một thời hạn nhất định phải hoàn trả cả gốc và lãi với mục đích phục vụ đời sống hoặc phục vụ sản xuất kinh doanh dưới hình thức hộ kinh doanh cá thể.

\subsubsection{Phân loại tín dụng theo tính chất đảm bảo}

- Tín dụng có tài sản đảm bảo

Theo Nguyễn Văn Tiến (2014), tín dụng có đảm bảo là tín dụng có tài sản cầm cố, thế chấp hoặc có bảo lãnh của người thứ ba. Hình thức tín dụng này áp dụng đối với những khách hàng không đủ uy tín, khi vay vốn phải có tài sản đảm bảo hoặc phải có người bảo lãnh. Tài sản đảm bảo hoặc bảo lãnh của người thứ ba là căn cứ pháp lý để ngân hàng có thêm nguồn thu dự phòng khi nguồn thu chính (dòng tiền) của con nợ thiếu hụt, do lo sợ phát mãi tài sản đã tạo áp lực buộc con nợ phải trả nợ, giảm thiểu rủi ro cho ngân hàng.

- Tín dụng không có tài sản đảm bảo

Theo Nguyễn Đăng Dờn (2012), tín dụng không có tài sản đảm bảo là loại cho vay áp dụng đối với những khách hàng truyền thống có quan hệ tín dụng với ngân hàng 
lâu năm, đồng thời đó là những khách hàng có tình trạng tài chính vững chắc, sản xuất kinh doanh ổn định, có lãi, có quan hệ tốt trong giao dịch với khách hàng và ngân hàng - nợ nần được thanh toán song phẳng kịp thời.

Những khách hàng được xếp hạng phân loại tín nhiệm thuộc loại I (hoặc loại $\mathrm{A}$ ) đều được ngân hàng cho vay mà không cần tài sản thế chấp, cầm cố hoặc bảo lãnh của bên thứ ba.

Thông thường thì khi cho vay không có tài sản đảm bảo, ngân hàng căn cứ vào phương án sản xuất kinh doanh và khả năng trả nợ của khách hàng để cho vay, đây là loại cho vay nên được nhân rộng để giảm bớt những thủ tục và chi phí trung gian không cần thiết.

\subsubsection{3 Đặc điểm của tín dụng cá nhân không có tài sản đảm bảo}

Theo Nguyễn Văn Tiến (2014), tín dụng cá nhân không có tài sản đảm bảo có các đặc điểm sau

1. Đối tượng được cấp tín dụng: bao gồm các cá nhân và hộ gia đình

2. Quy mô các món vay thường nhỏ, nhưng số lượng các món vay lại lớn, do đó chi phí tổ chức cho vay cao, là một trong những nguyên nhân khiến cho lãi suất cao hơn lãi suất cho vay thương mại hay công nghiệp.

3. Cho vay cá nhân không có tài sản đảm bảo có rủi ro cao hơn so với cho vay thương mại hay công nghiệp, bởi vì các khoản vay này không những chịu rủi ro của những nhân tố khách quan mà còn chịu rủi ro xuất phát từ bản thân khách hàng như điều kiện tài chính của cá nhân hay hộ gia đình có thể thay đổi bất lợi rất nhanh do bệnh tật, tai nạn, thất nghiệp hay các bi kịch gia đình.

4. Thời hạn vay thường ngắn, nên lãi suất thường là cố định, do đó không phản ánh được những thay đổi của thị trường, điều này khiến các hợp đồng cho cá nhân không có tài sản đảm bảo bộc lộ rủi ro lãi suất là rất lớn.

5. Nhu cầu vay của khách hàng hầu như ít co giãn với lãi suất. Xuất phát từ giá trị khoản vay thường nhỏ, nên thông thường người đi vay quan tâm đến số tiền phải thanh toán định kỳ hơn là lãi suất mà họ phải chịu.

6. Nhu cầu vay của khách hàng thường phụ thuộc vào chu kỳ kinh tế. Khi kinh tế tăng trưởng, người dân lạc quan về thu nhập trong tương lai nên có xu hướng tăng chi tiêu cho tiêu dùng, kích thích tín dụng cá nhân tăng trưởng; 
ngược lại, khi kinh tế suy thoái, thu nhập của người dân giảm, họ bi quan về nguy cơ thất nghiệp nên có xu hướng tiết kiệm, chi tiêu ít hơn... khiến cho tín dụng giảm xuống.

7. Mức thu nhập và trình độ học vấn là hai biến số có mối quan hệ mật thiết tới nhu cầu vay của khách hàng. Thu nhập càng cao thì chi tiêu cũng càng lớn, nên việc vay mượn được xem như công cụ để đạt mức sống cao hơn, tiện nghi hơn, chứ không đơn thuần chỉ là ăn no mặc ấm. Với trình độ học vấn cao hơn, thì thu nhập cũng cao hơn, làm cho các khoản vay của họ trở nên an toàn hơn không chỉ vì có nguồn trả nợ tốt mà còn an toàn về nhận thức, tư cách đạo đức của người vay. Học vấn cao thường nhận được sự tin tưởng của ngân hàng nên họ dễ dàng được vay và có xu hướng vay được nhiều hơn. Ngược lại những người có học vấn thấp thì có xu hướng vay khó hơn, số tiền vay được ít hơn, chịu sự giám sát chật chẽ của ngân hàng, thậm chí không được ngân hàng cấp tín dụng.

8. Chất lượng thông tin tài chính của khách hàng thường không cao. Điều này là vì các công ty muốn vay ngân hàng phải xuất trình các báo cáo tài chính và thường phải có xác nhận của các công ty kiểm toán, trong khi đó, những thông tin tài chính cá nhân rất khó kiểm chứng.

Tư cách của khách hàng là yếu tố khó xác định, song lại rất quan trọng, quyết định sự hoàn trả của khoản vay. Cũng như bất kỳ khoản vay nào, đây là chỉ tiêu quan trọng để ngân hàng thẩm định trước khi quyết định cho vay. Đối với cho vay cá nhân không có tài sản đảm bảo, thì tư cách người vay lại càng có vay trò quan trọng, nhưng tư cách người vay là nhân tố định tính nên rất khó xác định chính xác. Tư cách người vay quyết định tới việc sử dụng vốn vay đúng mục đích và là yếu tố quyết định thiện chí hoàn trả khoản vay. Do đó, tư cách người vay càng được đánh giá cao, thì khả năng trả nợ của khách hàng càng cao, giảm được rủi ro tín dụng cho ngân hàng.

\subsubsection{Rủi ro tín dụng}

\subsubsection{Khái niệm về rủi ro tín dụng}

Căn cứ vào Khoản 1 Điều 2 của Quy định về phân loại nợ, trích lập và sử dụng dự phòng để xử lý rủi ro, theo Quyết định số 493/2005/QĐ-NHNN ngày 22/4/2005 của Thống đốc NHNN thì: "Rủi ro tín dụng trong hoạt động ngân hàng của tổ chức 
tín dụng là khả năng xảy ra tổn thất trong hoạt động ngân hàng của tổ chức tín dụng, do khách hàng không thực hiện hoặc không có khả năng thực hiện nghĩa vụ của mình theo cam kết."

Theo Nguyễn Đăng Dờn (2011), thì rủi ro tín dụng có thể xuất hiện trong các mối quan hệ mà trong đó ngân hàng là chủ nợ, khách hàng nợ lại không thực hiện hoặc không đủ khả năng thực hiện nghĩa vụ trả nợ khi đến hạn. Nó diễn ra trong quá trình cho vay, chiết khấu công cụ chuyển nhượng và giấy tờ có giá, cho thuê tài chính, bảo lãnh, bao thanh toán của ngân hàng.

\subsubsection{Phân loại rủi ro tín dụng}

Cũng theo Nguyễn Đăng Dờn (2011), rủi ro tín dụng được chia thành các loại sau:

\section{- Rủi ro giao dịch}

Rủi ro giao dịch là một hình thức của rủi ro tín dụng mà nguyên nhân phát sinh là do những hạn chế trong quá trình giao dịch và xét duyệt cho vay, đánh giá khách hàng. Rủi ro giao dịch có 3 bộ phận chính là rủi ro lựa chọn, rủi ro đảm bảo và rủi ro nghiệp vụ.

Rủi ro giao dịch là loại hình rủi ro tín dụng phát sinh trong quá trình giao dịch tín dụng giữa ngân hàng và khách hàng. Rủi ro giao dịch là rủi ro mang nặng tính chủ quan của bên cho vay trong quá trình tác nghiệp, bao gồm:

Rủi ro lựa chọn: Quá trình đánh giá, phân tích, lựa chọn khi tác nghiệp chưa tốt:

- Phân tích, đánh giá khách hàng thiếu bao quát, còn nhiều sơ hở.

- Phân tích, lựa chọn phương án vay vốn của khách hàng còn lỏng lẻo, qua loa.

- Lựa chọn phương án thu nợ thiếu cân nhắc có nhiều sơ hở dẫn đến rủi ro.

Rủi ro đảm bảo là rủi ro các vấn đề liên quan đến tài sản đảm bảo:

- Điều khoản đảm bảo tín dụng thiếu chặt chẽ, rõ ràng.

- Danh mục tài sản đảm bảo thiếu tính cụ thể.

- Hình thức đảm bảo và phương pháp xử lý tài sản còn bất cập.

- Tỷ lệ tài sản đảm bảo thiếu dứt khoát, rõ ràng.

- Rủi ro nghiệp vụ là rủi ro liên quan đến công tác quản lý khoản vay và hoạt động cho vay, bao gồm cả việc sử dụng hệ thống xếp hạng rủi ro và kỹ thuật xử lý các khoản vay có vấn đề. 


\section{- Rủi ro danh mục}

Rủi ro danh mục là loại hình rủi ro tín dụng phá sinh trong quản lý danh mục cho vay của ngân hàng. Rủi ro danh mục là loại rủi ro vừa mang tính chủ quan, lại vừa chịu tác động của các nhân tố khách quan. Rủi ro danh mục bao gồm rủi ro nội tại và rủi ro tập trung.

- Rủi ro nội tại: Rủi ro nội tại xuất phát từ các yếu tố, các đặc điểm riêng có, mang tính riêng biệt bên trong của mổi chủ thể đi vay hoặc ngành, lĩnh vực kinh tế. Nó xuất phát từ đặc điểm hoạt động hoặc đặc điểm sử dụng vốn của khách hàng vay vốn.

Rủi ro nội tại xuất phát từ các yếu tố rủi ro bên trong của mỗi khách hàng vay vốn, ngành nghề kinh doanh, lĩnh vực hoạt động.

- Rủi ro tập trung: Rủi ro tập trung là rủi ro phát sinh trong trường hợp ngân hàng tập trung vốn cho vay quá nhiều đối với một số khách hàng, cho vay quá nhiều doanh nghiệp hoạt động trong cùng một ngành, lĩnh vực kinh tế; hoặc trong cùng một vùng địa lý nhất định; hoặc cùng một loại hình cho vay có rủi ro cao.

\subsubsection{Nguyên nhân rủi ro tín dụng}

Theo Nguyễn Đăng Dờn (2011), thì nguyên nhân rủi ro tín dụng bao gồm

\section{Nhóm nguyên nhân khách quan}

Nguyên nhân khách quan gây tác động và ảnh hưởng trên bình diện rộng:

- Do sự biến động của môi trường kinh tế (nội địa, toàn cầu)

- Những bất cập trong cơ chế, chính sách của nhà nước

- Hành lang pháp lý cho hoạt động ngân hàng chưa hoàn thiện

- Những nguyên nhân bất khả kháng (thiên tai, bệnh dịch..)

\section{> Nhóm nguyên nhân thuộc về người đi vay}

- Tình hình sản xuất kinh doanh thiếu ổn định vững chắc

- Tình hình tài chính không tốt

- Công tác quản lý kinh doanh còn hạn chế

- Thái độ thiếu thiện chí và bất hợp tác của người đi vay

- Hiện tương cố ý, cố tình lừa đảo

\section{Nhóm nguyên nhân thuộc về ngân hàng cho vay}


- Chính sách tín dụng chưa hợp lý

- Chưa nêu cao tính tự chủ và tự chịu trách nhiệm trong hoạt động tín dụng

- Chưa xác định đúng quy mô và tốc độ tăng trưởng của tính dụng.

- Chưa có chính sách khách hàng hợp lý

- Chưa linh hoạt trong lãi suất và ưu đãi lãi suất

- Chưa đơn giản hoá quy trình thủ tục cấp tín dụng.

- Chưa có chiến lược cạnh tranh và marketing hợp lý.

- Quá cứng nhắc trong việc xác định và kiểm soát hạn mức tín dụng.

- Quy trình cho vay có nhiều kẻ hở bị khách hàng lợi dụng.

- Trình độ chuyên môn nghiệp vụ của cán bộ tín dụng còn hạn chế.

- Đạo đức kinh doanh chưa tốt.

Các nguyên nhân nêu trên, trước hết phải nói đến các ngân hàng còn thiếu một chính sách tín dụng nhất quán, chính sách tín dụng ở đây phải bao gồm định hướng chung cho việc cho vay, chế độ tín dụng ngắn hạn, trung và dài hạn, các quy định về đảm bảo tiền vay, danh mục lựa chọn khách hàng trong từng giai đoạn.

Ngân hàng không có đủ thông tin về các số liệu thống kê để phân tích và đánh giá khách hàng, dẫn đến việc xác định sai hiệu quả của phương án xin vay, hoặc xác định thời hạn cho vay và trả nợ không phù hợp với phương án kinh doanh của khách hàng.

Sự lơi lỏng trong quá trình giám sát trước, trong và sau khi cho vay, làm cho ngân hàng không phát hiện kịp thời dù vốn vay đã bị sử dụng sai mục đích.

Ngân hàng quá tin tưởng vào tài sản thế chấp, tài sản cầm cố, bảo lãnh, bảo hiểm, coi đó là sự đảm bảo chắc chắn cho sự thu hồi vốn vay.

Chạy theo thành tích số lượng hoặc chỉ tiêu kế hoạch mà xem nhẹ chất lượng khoản tín dụng, quá tin tưởng vào phương án kinh doanh của khách hàng.

Năng lực chuyên môn và đạo đức nghề nghiệp của một số cán bộ tín dụng ngân hàng chưa theo kịp yêu cầu. Quản lý, sử dụng, đãi ngộ cán bộ ngân hàng chưa thoả đáng, không giữ được cán bộ có tài năng.

Cạnh tranh giữa các ngân hàng quá gay gắt thậm chí còn chưa thực sự lành mạnh, việc chạy theo quy mô, bỏ qua các tiêu chuẩn, điều kiện trong cho vay, thiếu quan tâm đến chất lượng khoản vay. 


\subsubsection{Rủi ro tín dụng khách hàng cá nhân}

Cũng theo Nguyễn Lê Ngọc Ca (2011), tín dụng cá nhân thường dẫn đến các rủi ro:

- Rủi ro thông tin bất cân xứng

Khi thẩm định cho vay thì thông tin về bản thân khách hàng là một trong những yếu tố quan trọng để ngân hàng đưa đến quyết định cho vay, bên cạnh tính hợp lý và hợp pháp của như cầu vay vốn, khả năng trả nợ và tài sản đảm bảo.

Đối với khách hàng cá nhân, việc đánh giá nhân thân, nguồn trả nợ, mục đích sử dụng vốn vay thường khó đầy đủ và rõ ràng dẫn đến rủi ro thông tin bất cân xứng, khiến cho việc thẩm định khách hàng thiếu chính xác. Nguồn trả nợ chủ yếu của khách hàng cá nhân là từ thu nhập ổn định ở thời điểm hiện tại. Do vậy, nếu người vay gặp vấn đề về sức khoẻ, mất việc làm hay gặp các biến cố bất ngờ ảnh hưởng đến thu nhập thì sẽ không trả được nợ vay cho ngân hàng.

- Rủi ro tác nghiệp

Do đặc điểm của tín dụng cá nhân là quy mô mỗi khoản vay nhỏ nhưng số lượng khoản vay lớn, vì vậy để có thể đáp ứng tối đa nhu cầu khách hàng nhằm nâng cao kết quả công việc đòi hỏi sự phục vụ nhanh chóng của cán bộ tín dụng. Do đó, trong quá trình thẩm định hồ sơ tín dụng các cán bộ thường hay chủ quan, thậm chí lợi dụng sự lỏng lẽo của công tác quản lý và sơ hở của các quy định để lừa đảo chiếm đoạt tài sản khách hàng, hoặc thông đồng với khách hàng gây ra những tổn thất cho ngân hàng.

Rủi ro này còn tăng lên gấp đôi đối với vay không có tài sản đảm bảo, do ngân hàng cấp tín dụng dựa trên cơ sở thẩm định uy tín của hách hàng tốt hay xấu mà không có biện pháp đảm bảo bằng tài sản. Trong trường hợp đó, nếu khách hàng thực sự không có khả năng trả nợ vay hoặc có khả năng nhưng không có ý chí trả nợ vay trong khi việc quản lý thông tin về sự thay đổi nơi cư trú, công việc của khách hàng là một điều không dễ dàng thì sẽ rất khó khăn cho ngân hàng khi xứ lý khoản vay để thu hồi nợ.

\subsection{3 Ảnh hưởng của rủi ro tín dụng}

\subsubsection{Tác động đến hoạt động kinh doanh của ngân hàng}

Khi rủi ro tín dụng xảy ra, ngân hàng không thu được vốn tín dụng đã cấp và lãi cho vay, nhưng ngân hàng phải trả vốn và lãi cho khoản tiền huy động khi đến hạn, 
điều này sẽ làm cho ngân hàng mất cân đối trong việc thu chi, vòng quay vốn tín dụng giảm làm cho ngân hàng kinh doanh không hiệu quả, chi phí của ngân hàng sẽ tăng lên so với dự kiến.

Nếu một khoản vay nào đó bị mất khả năng thu hồi, thì ngân hàng phải sử dụng các nguồn vốn để trả cho người gởi tiền, đến một chừng mực nào đấy, ngân hàng không có đủ vốn để trả cho người gởi tiền thì ngân hàng sẽ rơi vào tình trạng mất khả năng thanh toán, có thể dẫn đến nguy cơ gặp rủi ro thanh toán. Và kết quả là làm thu hẹp quy mô kinh doanh, năng lực tài chính giảm sút, uy tín, sức cạnh tranh giảm không những trong thị trường nội địa mà còn lan rộng ra các nước, kết quả kinh doanh của ngân hàng ngày càng xấu, có thể dẫn đến ngân hàng thua lỗ hoặc đưa đến bờ vực phá sản, nếu không có biện pháp xử lý, khắc phục kịp thời.

\subsubsection{Tác động đến nền kinh tế xã hội}

Ngân hàng thương mại là một tổ chức trung gian tài chính chuyên huy động vốn nhàn rỗi trong nền kinh tế để cho các tổ chức, các doanh nghiệp và cá nhân có nhu cầu vay lại. Do đó khi rủi ro tín dụng xảy ra, thì không những ngân hàng chịu thiệt hại mà quyền lợi của người gởi tiền cũng bị ảnh hưởng.

Khi một ngân hàng gặp rủi ro tín dụng với mức độ lớn, sẽ ảnh hưởng đến người gởi tiền làm cho người gởi tiền hoang mang, lo sợ và kéo nhau đến rút tiền, không những ở ngân hàng có sự cố mà còn ở những ngân hàng khác, làm cho toàn bộ hệ thống ngân hàng gặp phải khó khăn. Khủng hoảng thanh khoản xảy ra và ảnh hưởng rất nghiêm trọng đến sự tồn tại và phát triển của hệ thống ngân hàng.

Hệ thống ngân hàng bị ảnh hưởng, hoạt động không hữu hiệu sẽ ảnh hưởng đến toàn bộ nền kinh tế - xã hội. Nó có thể làm cho nền kinh tế bị suy giảm, lạm phát tăng, sức mua giảm, thất nghiệp tăng, xã hội mất ổn định..

Tóm lại, rủi ro tín dụng của các ngân hàng xảy ra ở những mức độ khác nhau, rủi ro cấp độ nhẹ cũng làm cho ngân hàng bị giảm lợi nhuận, rủi ro ở cấp độ nặng làm cho ngân hàng không thu đủ vốn lãi, hoặc mất cả vốn lẫn lãi, dẫn đến ngân hàng bị thua lỗ. Nếu tình trạng này kéo dài không khắc phục được, ngân hàng sẽ bị phá sản, gây hậu quả nghiêm trọng cho nền kinh tế nói chung và hệ thống ngân hàng nói riêng. Chính vì vậy đòi hỏi các nhà quản trị ngân hàng phải hết sức thận trọng và có những biện pháp thích hợp để ngăn ngừa và hạn chế rủi ro tín dụng. 


\subsection{Giới thiệu một số nghiên cứu trước đây về đo lường các yếu tố ảnh hưởng đến rủi ro tín dụng}

(1)Trương Đông Lộc (2011), Các nhân tố ảnh hưởng đến rủi ro tín dụng của Ngân hàng thương mại cổ phần Ngoại thương chi nhánh TP Cần Thơ,Tạp chí Ngân hàng

Với mục đích xác định các nhân tố ảnh hưởng đến rủi ro tín dụng của Ngân hàng thương mại cổ phần Ngoại thương chi nhánh TP Cần Thơ, tác giả đã nghiên cứu trên 438 khách hàng từ thời điểm 1/1/2009 đến 31/12/2009. Trong bài viết này, tác giả nghiên cứu trên 2 nhóm khách hàng: cá nhân và doanh nghiệp. Sử dụng mô hình xác suất Propit

$Y=\alpha+\beta 1 X 1+\beta 2 X 2+\beta 3 X 3+\beta 4 X 4+\beta 5 X 5+\beta 6 X 6+\beta 7 X 7+e$

Trong đó: $\mathrm{Y}$ : mức độ rủi ro của khoản vay ( $\mathrm{Y}=1$ : có rủi ro, $\mathrm{Y}=0$ : không có rủi ro)

Bảng 2.1 Các biến độc lập trong mô hình của Trương Đông Lộc

\begin{tabular}{|c|c|c|}
\hline Biến số & Diễn giải biến & Ghi chú \\
\hline $\mathrm{X} 1$ & Kinh nghiệm của $\mathrm{KH}$ đi vay & Số năm làm việc của $\mathrm{KH}$ \\
\hline $\mathrm{X} 2$ & $\begin{array}{l}\text { Khả năng tài chính của } \mathrm{KH} \\
\text { vay }\end{array}$ & $\begin{array}{l}\text { Vốn tự có tham gia vào phương án, dự } \\
\text { án/Tổng nhu cầu vốn của phương án/dự án }\end{array}$ \\
\hline $\mathrm{X} 3$ & Tài sản đảm bảo & Số tiền vay/Tổng TS đảm bảo \\
\hline $\mathrm{X} 4$ & Sử dụng vốn vay & $\begin{array}{l}\text { Biến giả bằng } 1 \text { nếu } \mathrm{KH} \text { sử dụng vốn đúng } \\
\text { mục đích, bằng } 0 \text { nếu } \mathrm{KH} \text { sử dụng vốn sai } \\
\text { mục đích }\end{array}$ \\
\hline X5 & $\begin{array}{l}\text { Kinh nghiệm của cán bộ tín } \\
\text { dụng }\end{array}$ & Số năm trực tiếp làm công tác tín dụng \\
\hline X6 & $\begin{array}{l}\text { Đa dạng hoá hoạt động kinh } \\
\text { doanh }\end{array}$ & $\begin{array}{l}\text { Biến giả bằng } 1 \text { nếu } \mathrm{KH} \text { kinh doanh từ } 3 \\
\text { ngành hàng trở lên, bằng } 0 \text { cho các trường } \\
\text { hợp ngược lại }\end{array}$ \\
\hline $\mathrm{X} 7$ & $\begin{array}{l}\text { Kiểm tra, giám sát khoản } \\
\text { vay }\end{array}$ & $\begin{array}{l}\text { Tổng số lần kiểm tra của cán bộ tín dụng } \\
\text { trước khi chuyển khoản vay sang nợ xấu }\end{array}$ \\
\hline
\end{tabular}

Nguồn:Trương Đông Lộc, Nguyễn Thị Tuyết (2011)

Các khoản vay không có rủi ro là những khoản vay thuộc nhóm 1,2

Các khoản vay có rủi ro là những khoản vay thuộc nhóm nợ xấu nhóm 3,4,5 
Bảng 2.2 Kết quả nghiên cứu của Trương Đông Lộc

\begin{tabular}{|l|l|l|}
\hline Biến số & Diễn giải biến & $\begin{array}{l}\text { Hệ số tương } \\
\text { quan }\end{array}$ \\
\hline Hằng số & & 3.258 \\
\hline X1 & Kinh nghiệm của KH đi vay & -0.023 \\
\hline X2 & $\begin{array}{l}\text { Khả năng tài chính của KH } \\
\text { vay }\end{array}$ & -2.89 \\
\hline X3 & Tài sản đảm bảo & 0.357 \\
\hline X4 & Sử dụng vốn vay & -1.147 \\
\hline X5 & $\begin{array}{l}\text { Kinh nghiệm của cán bộ tín } \\
\text { dụng }\end{array}$ & -0.559 \\
\hline X6 & $\begin{array}{l}\text { Đa dạng hoá hoạt động kinh } \\
\text { doanh }\end{array}$ & -0.609 \\
\hline X7 & $\begin{array}{l}\text { Kiềm tra, giám sát khoản } \\
\text { vay }\end{array}$ & -0.32 \\
\hline Số mẫu quan sát & 2240803 & 438 \\
\hline R Square điều chỉnh & & 0.522 \\
\hline
\end{tabular}

Nguồn:Truơng Đông Lộc, Nguyễn Thị Tuyết (2011)

Kết quả nghiên cứu cho thấy các biến $\mathrm{X} 2, \mathrm{X} 4, \mathrm{X} 5, \mathrm{X} 6, \mathrm{X} 7$ là các biến có ý nghĩa trong mô hình. Cụ thể:

Khả năng tài chính của khách hàng đi vay (X2) có mối tương quan nghịch với xác suất xảy ra rủi ro tín dụng của khoản vay đó. Nói cách khác, nếu vốn tự có của người vay trong dự án càng lớn thì khả năng xảy ra rủi ro tín dụng càng thấp và ngược lại. Mối quan hệ này có ý nghĩa thống kê ở mức 5\%

Sử dụng vốn vay (X4): kết quả nghiên cứu cho thấy việc sử dụng vốn vay không đúng mục đích có thể sẽ dẩn đến rủi ro tín dụng cho ngân hàng. Kết luận này có ý nghĩa thống kê ở mức 1\% (độ tin cậy 99\%)

Kinh nghiệm của cán bộ tín dụng (X5) có tương quan nghịch với rủi ro tín dụng (ý nghĩa thống kê ở mức $1 \%$ ). Điều này có nghĩa là cán bộ tín dụng càng có 
nhiều kinh nghiệm thì khả năng xảy ra rủi ro tín dụng của các khoản vay mà họ quản lý càng thấp.

Đa dạng hoá hoạt động kinh doanh (X6): khả năng vượt qua khó khăn và giảm thiểu khả năng để xảy ra nợ xấu của các khách hàng có đa dạng hoá ngành nghề kinh doanh sẽ cao hơn so với nhóm khách hàng chỉ kinh doanh đơn độc một hoặc hai ngành hàng. Mối quan hệ giữa rủi ro tín dụng và việc đa dạng hoá ngành nghề kinh doanh của khách hàng có ý nghĩa thống kê ở mức 5\%

Kiểm tra, giám sát khoản vay (X7): kết quả nghiên cứu cho thấy số lần kiểm tra, giám sát có tương quan nghịch với rủi ro tín dụng, nghĩa là việc kiểm tra, giám sát càng chặt chẽ thì khả năng xảy ra rủi ro tín dụng càng thấp và ngược lại. Mối quan hệ này có ý nghĩa thống kê ở mức $1 \%$.

Trái ngược với kỳ vọng, $\mathrm{X} 1$ và $\mathrm{X} 3$ không có ảnh hưởng đến rủi ro tín dụng của ngân hàng. Từ đó tác giả khuyến nghị các ngân hàng khi cho vay không nên phụ thuộc quá nhiều vào tài sản đảm bảo mà nên quan tâm nhiều đến nhưng yếu tố khác như đã phân tích ở trên.

Từ kết quả nghiên cứu trên, đã cung cấp những bằng chứng thực tế có giá trị giúp cho các ngân hàng nói chung và ngân hàng TMCP Ngoại thương nói riêng hiểu rõ hơn các nguyên nhân dẫn đến rủi ro tín dụng, từ đó sẽ chủ động đưa ra các giải pháp phù hợp nhằm hạn chế rủi ro tín dụng.

Mô hình đã đưa ra được một cái nhìn tổng quát về các yếu tố ảnh hưởng đến rủi ro tín dụng tại Ngân hàng thương mại cổ phần Ngoại thương chi nhánh TP Cần Thơ, bao gồm cả tín dụng cá nhân và doanh nghiệp. Bên cạnh đó, khi xét về các yếu tố ảnh hưởng đến rủi ro tín dụng, ngoài các yếu tố từ phía khách hàng, mô hình còn đưa thêm được 2 biến về phía ngân hàng là Kinh nghiệm của cán bộ tín dụng (X5) và Kiểm tra, giám sát khoản vay (X7). Tuy nhiên, vì mang tính tổng quát cao nên khó có thể ứng dụng mô hình vào việc dự báo xác suất xảy ra rủi ro cụ thể của từng hoạt động cho vay. Bên cạnh đó, mô hình không xét đến các yếu tố đặc trưng của từng mảng cho vay, ví dụ như theo lý thuyết thì cho vay cá nhân cần quan tâm đến các yếu tố: độ tuổi, thu nhập, chi phí, số người phụ thuộc, khoản vay...; hoặc cho vay doanh nghiệp thì phải xét đến các chỉ số tài chính trên báo cáo tài chính. 
(2) Vương Quân Hoàng (2006), Phương pháp thống kê xây dựng mô hình định mức tín nhiệm thể nhân, Tạp chí ứng dụng toán học

Trong nghiên cứu này, tác giả lấy mẫu quan sát là 1728 khách hàng của $\mathrm{NH}$ Techcombank, trong đó có 1374 thuộc nhóm tốt và 354 khách hàng thuộc nhóm không tốt. Tác giả sử dụng mô hình hồi quy Logistics với:

$Z$ : biến phụ thuộc $(Z=1$ nếu $K H$ thuộc nhóm tốt, $Z=0$ nếu $K H$ thuộc nhóm không tốt)

$\mathrm{Xi}$ : các biến về đặc trưng của $\mathrm{KH}$

Kết quả mô hình như sau:

Bảng 2.3 Kết quả nghiên cứu mô hình của Vương Quân Hoàng

\begin{tabular}{|l|l|l|l|}
\hline Ký hiệu & Ý nghĩa & Hệ số $\beta$ & $\mathbf{P}$ - value \\
\hline $\boldsymbol{X 0 1}$ & Tuối tác & -1.2381 & 0.0237 \\
\hline $\boldsymbol{X 0 2}$ & Trình độ học vấn & -0.5911 & 0.1986 \\
\hline $\boldsymbol{X 0 3}$ & Loại hình công việc & -1.3719 & 0.0929 \\
\hline $\boldsymbol{X 0 4}$ & Thời gian công tác & - & - \\
\hline $\boldsymbol{X 0 5}$ & Mức thu nhập hàng tháng & 3.2401 & 0.0001 \\
\hline $\boldsymbol{X 0 6}$ & Tình trạng hôn nhân & -1.8337 & 0.0168 \\
\hline $\boldsymbol{X 0 7}$ & Nơi cư trú & -0.80706 & 0.0003 \\
\hline $\boldsymbol{X 0 8}$ & Thời gian cư trú & -5.3368 & 0.0004 \\
\hline $\boldsymbol{X 0 9}$ & Số người phụ thuộc & -1.0916 & 0.0224 \\
\hline $\boldsymbol{X 1 0}$ & Phương tiện đi lại & -1.508 & 0.0178 \\
\hline $\boldsymbol{X 1 1}$ & Phương tiện thông tin & -18.2826 & 0.0001 \\
\hline $\boldsymbol{X 1 2}$ & Chênh lệch thu nhập và chi tiêu & 5.6701 & 0 \\
\hline $\boldsymbol{X 1 3}$ & Giá trị TS KH & 3.595 & 0 \\
\hline $\boldsymbol{X 1 4}$ & Giá trị các khoản nợ & -0.9303 & 0.0303 \\
\hline $\boldsymbol{X 1 5}$ & Quan hệ với Techcombank & -1.4832 & 0.0634 \\
\hline $\boldsymbol{X 1 6}$ & Uy tín trong giao dịch & - & - \\
\hline
\end{tabular}

Nguồn: Vương Quân Hoàng (2006)

Từ kết quả ước lượng hồi quy Logistics, tác giả đã loại bỏ 2 biến X4 (thời gian công tác) và X16 (Uy tín trong giao dịch) ra khỏi mô hình vì 2 lý do:

- X4, X16 có sự phụ thuộc tuyến tính với các biến khác 
- Các ước lượng trong mô hình 16 biến tỏ ra không ổn định.

Từ đó, tác giả đưa ra mô hình hồi quy:

$Z=\ln (o d d s)=\ln (P i / 1-P i)=-1.238151 X 1-0.591102 X 2-1.371960 X 3+3.240103$ $X 5-1.833702 X 6-8.070600 X 7-5.336831 X 8-1.091618 X 9-1.508460 X 10-$ $18.28262 \times 11+5.670182 \times 12+3.595030 \times 13-0.930329 \times 14-1.482391 \times 15$

Với nguyên tắc gán $\mathrm{P}(\mathrm{x})>0.5$ thì khách hàng được xếp vào nhóm tốt, mô hình đã xác định đúng 1728 khách hàng, tương đương 99.02\%, đây là một tỷ lệ chính xác rất cao. Mô hình cũng đã đưa vào hầu hết các yếu tố ảnh hưởng đến rủi ro tín dụng cá nhân vào mô hình logistic và các biến đều có ý nghĩa theo như các lý thuyết (ngoại trừ 2 biến $\mathrm{X} 4$ và X16). Tuy nhiên, do tác giả tiếp cận với góc độ thiên về toán học, nên chưa có sự diễn giải, phân tích cụ thể sự tác động của từng yếu tố trong mô hình đến rủi ro tín dụng.

(3) Đinh Thị Huyền Thanh (2006), Mô hình điểm số tín dụng cá nhân áp dụng cho ngân hàng bán lẻ Việt Nam

Tác giả Đinh Thị Huyền Thanh và Stefanie Kleimeier đã tiến hành nghiên cứu trên 25,043 khoản vay tại các ngân hàng thương mại từ đó đưa ra 22 biến. Trong đó bao gồm độ tuổi, thu nhập, trình độ học vấn, nghề nghiệp, thời gian công tác, tình trạng cư ngụ, giới tính, tình trạng hôn nhân, mục đích vay, quan hệ với ngân hàng,... để xác định mức ảnh hưởng của các biến số này đến rủi ro tín dụng và qua đó thiết lập một mô hình điểm số tín dụng cá nhân áp dụng cho các ngân hàng bán lẻ tại Việt Nam.Nghiên cứu của Stefanie Kleimeier đã xây dựng mô hình chấm điểm tín dụng cá nhân gồm hai phần là chấm điểm nhân thân và năng lực trả nợ, chấm điểm quan hệ với ngân hàng. 
Bảng 2.4 Ký hiệu xếp hạng tín dụng cá nhân theo Stefanie Kleimeier

\begin{tabular}{|c|c|c|}
\hline Điểm & Xếp hạng & Ý nghĩa xếp hạng \\
\hline$>400$ & Aаa & \multirow{3}{*}{ Cho vay tối đa theo đề nghị của người vay } \\
\hline $351-400$ & Aa & \\
\hline $301-350$ & A & \\
\hline $251-300$ & Bbb & Cho vay theo Tài sản đảm bảo \\
\hline $201-250$ & $\mathrm{Bb}$ & Cho vay theo Tài sản đảm bảo và đánh giá đơn vay vốn \\
\hline $151-200$ & B & $\begin{array}{l}\text { Yêu cầu đánh giá thận trọng đơn vay vốn, và có Tài sản } \\
\text { đảm bảo đầy đủ }\end{array}$ \\
\hline $101-150$ & $\mathrm{Ccc}$ & \multirow{4}{*}{ Từ chối cho vay } \\
\hline $51-100$ & $\mathrm{Cc}$ & \\
\hline $0-50$ & $\mathrm{C}$ & \\
\hline 0 & $\mathrm{D}$ & \\
\hline
\end{tabular}

Nguồn: Dinh Thi Huyen Thanh \& Stafanie Kleimeier, (2006)

Bảng 2.5 Chỉ tiêu xếp hạng tín dụng cá nhân theo Stefanie Kleimeier

Bước 1: Chấm điểm nhân thân và năng lực trả nơ

\begin{tabular}{|c|c|c|c|c|}
\hline 1.Tuổi & 18-25 tuổi & 26-40 tuổi & 41-60 tuổi & $>60$ tuồi \\
\hline 2.Trình độ học vấn & Sau đại học & $\begin{array}{l}\text { Đại học, cao } \\
\text { đẳng }\end{array}$ & Trung học & Dưới trung học \\
\hline 3.Nghề nghiệp & Chuyên môn & Giúp việc & Kinh doanh & Hưu trí \\
\hline 4.Thời gian công tác & $<0.5$ năm & 0.5-1 năm & 1-5 năm & > 5 năm \\
\hline 5.Thời gian công tác hiện tại & $<0.5$ năm & 0.5-1 năm & 1-5 năm & $>5$ năm \\
\hline 6.Tình trạng cư trú & Nhà riêng & Nhà thuê & $\begin{array}{l}\text { Sống cùng } \\
\text { gia đình }\end{array}$ & Khác \\
\hline 7. Số người phụ thuộc & Độc thân & 1-3 người & 3-5 người & $>5$ người \\
\hline 8.Thu nhập hàng năm & $\begin{array}{l}<12 \text { triệu } \\
\text { đồng }\end{array}$ & $\begin{array}{l}\text { 12-36 triệu } \\
\text { đồng }\end{array}$ & $\begin{array}{l}36-120 \\
\text { triệu đồng }\end{array}$ & > 120 triệu \\
\hline $\begin{array}{l}\text { 9.Thu nhập hàng năm của } \\
\text { gia đình }\end{array}$ & $\begin{array}{l}<24 \text { triệu } \\
\text { đồng }\end{array}$ & $\begin{array}{l}\text { 24-72 triệu } \\
\text { đồng }\end{array}$ & $\begin{array}{l}72-240 \\
\text { triệu đồng }\end{array}$ & $\begin{array}{l}>\quad 240 \text { triệu } \\
\text { đồng }\end{array}$ \\
\hline
\end{tabular}

Nguồn: Dinh Thi Huyen Thanh \& Stafanie Kleimeier, (2006) 
Bước 2: Chấm điểm quan hệ với ngân hàng

\begin{tabular}{|c|c|c|c|c|}
\hline $\begin{array}{l}\text { 1.Thực hiện cam kết với } \\
\text { ngân hàng( Ngắn hạn) }\end{array}$ & $\begin{array}{l}\text { Khách } \\
\text { hàng mới }\end{array}$ & $\begin{array}{l}\text { Chưa bao giờ } \\
\text { trễ hạn }\end{array}$ & $\begin{array}{l}\text { Có trễ hẹn ít } \\
\text { hơn } 30 \text { ngày }\end{array}$ & $\begin{array}{l}\text { Có trễ hạn } \\
\text { hơn } 30 \text { ngày }\end{array}$ \\
\hline $\begin{array}{l}\text { 2.Thực hiện cam kết với } \\
\text { ngân hàng( Dài hạn) }\end{array}$ & $\begin{array}{l}\text { Khách } \\
\text { hàng mới }\end{array}$ & $\begin{array}{l}\text { Chưa bao giờ } \\
\text { trễ hạn }\end{array}$ & $\begin{array}{l}\text { Có trễ } \\
\text { trong } 2 \text { năm } \\
\text { gần đây }\end{array}$ & $\begin{array}{l}\text { Có trễ hạn } \\
\text { trước } 2 \text { năm } \\
\text { gần đây }\end{array}$ \\
\hline $\begin{array}{l}\text { 3.Tổng giá trị khoản vay } \\
\text { chưa trả }\end{array}$ & $\begin{array}{l}<\quad 100 \\
\text { triệu đồng }\end{array}$ & $\begin{array}{l}\text { 100-500 triệu } \\
\text { đồng }\end{array}$ & $\begin{array}{l}500 \text { triệu đồng- } \\
1 \text { tỷ đồng }\end{array}$ & $>1$ tỷ đồng \\
\hline $\begin{array}{l}\text { 4.Các dịch vụ khác đang } \\
\text { sử dụng }\end{array}$ & $\begin{array}{l}\text { Tiền gửi } \\
\text { tiết kiệm }\end{array}$ & Thẻ & $\begin{array}{l}\text { Tiền gửi tiết } \\
\text { kiệm, thẻ tín } \\
\text { dụng }\end{array}$ & Không \\
\hline $\begin{array}{l}\text { 5.Số dư bình quân TKTK } \\
\text { trong năm trước đây }\end{array}$ & $\begin{array}{l}<20 \text { triệu } \\
\text { đồng }\end{array}$ & $\begin{array}{l}\text { 20-100 triệu } \\
\text { đồng }\end{array}$ & $\begin{array}{l}\text { 100-500 triệu } \\
\text { đồng }\end{array}$ & $\begin{array}{l}>500 \text { triệu } \\
\text { đồng }\end{array}$ \\
\hline
\end{tabular}

Nguồn: Dinh Thi Huyen Thanh \& Stafanie Kleimeier, 2006. Credit Scoring for

Vietnam's Retail Banking Market

Tuy nhiên, theo Lê Văn Triết (2010). Hoàn thiện hệ thống xếp hạng tín dụng cá nhân của ngân hàng TMCP Á châu, luận án thạc sĩ kinh tế, trường ĐH Kinh tế TP.HCM: công trình nghiên cứu này không đưa ra cách tính điểm cụ thể cho từng chỉ tiêu, để vận dụng mô hình đòi hỏi các NHTM phải thiết lập thang điểm cho từng chỉ tiêu đánh giá phù hợp với thực trạng và hệ thống cơ sơ dữ liệu cá nhân tại ngân hàng mình.

\subsection{Mô hình đo lường rủi ro tín dụng}

\subsubsection{Giới thiệu một số mô hình đo lường rủi ro tín dụng}

\subsubsection{Các mô hình định tính}

\section{(1) Mô hình 6C}

> Tính cách người đi vay (Character)

Được thể hiện qua mục đích xin vay rõ ràng, ý định trả nợ nghiêm túc, trung thực trong việc cung cấp tài liệu liên quan đến tình hình tài chính, có trách nhiệm đối với khoản vay. Để xác định được tính cách này ngân hàng sẽ khảo sát thành tích thanh toán của khách hàng trong quá khứ, dựa vào những kinh nghiệm của những ngân hàng 
khác đã từng cho vay đối với khách hàng này (thông qua Trung tâm thông tin tín dụng - CIC và ngân hàng thương mại khác) hoặc trực tiếp phỏng vấn khách hàng.

$>$ Năng lực của người đi vay (Capacity)

Năng lực pháp lý và năng lực trả nợ vay của khách hàng. Đòi hỏi người đi vay phải có năng lực pháp luật dân sự và năng lực hành vi dân sự. Cụ thể nếu người đi vay là một pháp nhân thì phải có giấy phép đăng ký kinh doanh, giấy phép hành nghề, có quyết định thành lập, quyết định bổ nhiệm ban giám đốc và kế toán trưởng. Thực hiện hoạch toán độc lập, tự chủ về tài chính. Nếu người đi vay là thể nhân thì phải trên 18 tuổi, không mắc bệnh tâm thần...

Bất kể người đi vay có nhu cầu vay vốn để làm gì (sản xuất kinh doanh hoặc tiêu dùng) đều phải chứng minh năng lực trả nợ của mình. Nếu người đi vay chứng tỏ có khả năng vay vốn, đồng thời có khả năng tạo nguồn để trả nợ mới thoả mãn điều kiện cho vay của ngân hàng.

Nguồn tiền để trang trải khoản vay (Cashflows)

Để đánh giá nguồn trả nợ của người đi vay, ngân hàng có thể phán đoán thông qua:

Lịch sử hoạt động kinh doanh và tăng trưởng của khách hàng về lợi nhuận, doanh thu.

Mức tăng trưởng lợi nhuận cao hay thấp.

Thu nhập trong quá khứ cũng như hiện tại của người đi vay

> Sự đảm bảo của khoản vay (Collateral)

Điều kiện, môi trường kinh doanh của người đi vay.

Vị thế của người đi vay trong ngành hoặc lĩnh vực kinh doanh.

Thị phần mà người đi vay đã có được.

Tình trạng lao động, viễn cảnh dài hạn của ngành nghề mà người đi vay đang hoạt động.

Hệ số tài sản đảm bảo

Sự bảo lãnh của người thứ 3

Quyền sở hữu của người đi vay đối với tài sản kinh doanh

Tình trạng của tài sản, tuổi đời của tài sản. 
Cần chú ý là tài sản đảm bảo chỉ là nguồn trả nợ thứ hai, còn nguồn thứ nhất lúc nào cũng là khả năng mang lại thu nhập từ dự án vay vốn, từ lưu lượng tiền mặt và thu nhập của người đi vay.

Điều kiện - môi trường kinh doanh của người đi vay (conditions)

Ngân hàng phải đánh giá được mặt hàng sản xuất, ngành nghề hoạt động của người đi vay có xu hướng sẽ được mở rộng hay thu hẹp; những điều kiện kinh tế đang thay đổi sẽ ảnh hưởng thế nào đến khoản vay...

Để đánh giá được chính xác, các ngân hàng phải thu thập các thông tin từ nhiều nguồn khác nhau liên quan đến tình trạnh kinh doanh của một số khách hàng có vai trò đại diện trong ngành.

$>$ Khả năng kiểm soát (Control)

Đây là khả năng mà ngân hàng có thể kiểm soát được đối với người đi vay: kiểm tra mục đích sử dụng vốn, kiểm tra hiệu quả sử dụng vốn.

\section{(2) Mô hình 5P}

Người vay vốn - Person/people

Phân tích người vay thực chất là trả lời câu hỏi: "Khách hàng vay là ai? Năng lực và thiện chí trả nợ của họ như thế nào? Để trả lời câu hỏi này, cán bộ tín dụng cần tập trung phân tích các nội dung:

Người vay là cá nhân hay tổ chức

Loại hình doanh nghiệp và ngành nghề của người vay

Cấu trúc tổ chức của người vay.

Lịch sử thanh toán/trả nợ với ngân hàng và với các chủ nợ khác.

Các thông tin khác về tư cách và năng lực khách hàng vay.

> Mục đích vay vốn - Purpose of the loan

Là việc phân tích để trả lời câu hỏi "Người vay vốn sẽ sử dụng vốn vay vào mục đích gì?” Mục đích sử dụng vốn vay rất phong phú và đa dạng như tài trợ vốn lưu động, tài trợ mua tài sản cố định, tài trợ dự án, cho vay tiêu dùng, hay vay để đảo nợ. Hơn nữa, mục đích vay vốn cũng chính là mục đích sử dụng vốn, mà mục đích sử dụng vốn gắn liền với mức độ rủi ro, kỳ hạn, nguồn trả nợ... Chính vì vậy, việc mục đích vay vốn cũng như đảm bảo nguyên tắc sử dụng vốn vay đúng mục đích được các ngân hàng phân tích và giám sát chặt chẽ. 
$>$ Nguồn trả nợ - Payment resoures

Là việc phân tích năng lực trả nợ của người vay khi hợp đồng đến hạn. Nguồn trả nợ vay là cực kỳ quan trọng bởi vì kết quả phân tích cho biết ngân hàng sẽ thu hồi nợ "gốc và lãi" như thế nào. Thông thường, nguồn trả nợ sơ cấp phát sinh từ chính dòng tiền vào của người vay, còn nguồn thu nợ thứ cấp là kết quả từ việc xử lý tài sản đảm bảo, bồi thường của người bảo lãnh. Nguồn thu nợ thứ cấp chỉ phát sinh khi người vay không trả được nợ đầy đủ và đúng hạn như quy định của hợp đồng. Việc ấn định kỳ trả nợ và số tiền trả định kỳ phải phù hợp với tính chất khoảng vay. Việc phân tích nguồn trả nợ là rất phức tạp, bởi vì việc trả nợ diễn ra trong tương lai, trong khi nguồn thông tin phân tích thường là lấy từ quá khứ

$>$ Đảm bảo tiền vay - Protection

Là việc phân tích để đảm bảo rằng tài sản đảm bảo đáp ứng được đầy đủ về:

Điều kiện pháp lý

Điều kiện thanh khoản

Điều kiện giá trị

$>$ Triển vọng người vay - Prospects

Là việc phân tích để trả lời câu hỏi "Triển vọng kinh doanh của người vay để tiếp tục trả nợ vay là như thế nào?” Để trả lời câu hỏi này, cán bộ tín dụng cần tập trung phân tích các nội dung:

Chính sách (kế hoạch) kinh doanh liên tục của khách hàng

Xu hướng và triển vọng kinh doanh của công ty

Xu hướng và triển vọng kinh doanh của ngành nghề kinh doanh

Các dự báo kinh tế

Thay đổi môi trường kinh doanh (các phát triển mới) ảnh hưởng như thế nào đến khách hành.

\section{(3) Mô hình CAMPARI}

Tư cách người vay - Character

Ngân hàng phân tích và đánh giá mức độ uy tín của bên vay trong việc thực hiện các hợp đồng kinh tế, việc thanh toán nợ lãi... để từ đó tuỳ theo mức độ tín nhiệm mà ngân hàng có những điều khoản rang buộc về trách nhiệm trả nợ của họ. 
Tư cách người vay có thể được xác minh và phán đoán bằng cách xem xét các thông tin sau đây:

Những thông tin lịch sử về quan hệ của khách hàng với ngân hàng, giữa khách hàng với các bạn hàng của ngân hàng.

Những đánh giá có được thông qua việc phỏng vấn khách hàng.

$>$ Năng lực vay và hoàn trả nợ vay - Ability

Khi quyết định cho vay ngân hàng không những chỉ căn cứ vào khả năng hoặc năng lực vay vốn của bên vay, mà còn phải chú trọng xem xét năng lực trả nợ của họ. Cụ thể, tập trung vào những điểm sau:

Đối với khách hàng cá nhân: Trình độ chuyên môn và năng lực quản lý, điều hành của cá nhân đó; thu nhập cá nhân; tình hình sức khoẻ, tính cách đạo đức...

Đối với khách hàng doanh nghiệp: tình hình tài chính của doanh nghiệp; địa điểm và vị trí kinh doanh; chất lượng và giá cả của sản phẩm, khả năng cạnh tranh, đội ngũ cán bộ quản lý...

$>$ Lãi cho vay - Margin

Lãi suất cho vay có thể là lãi suất cố định hoặc thả nổi

$>$ Mục đích vay - Purpose

Mục đích cho vay phải phù hợp với thể lệ tín dụng hiện hành

Số tiền cho vay - Amount

Khi xác định số tiền xin vay ngân hàng căn cứ các yếu tố sau:

Nhu cầu vốn cần thiết cho phương án

Vốn tự có của khách hàng tham gia vào phương án

$>$ Sự hoàn trả - Repayment

Khi phân tích khả năng hoàn trả nợ vay, ngân hàng cần xem xét nguồn trả nợ cho ngân hàng chính là nguồn nào? Khả năng thu được của nguồn này là bao nhiêu? Từ đó xác định được việc hoàn trả nợ cho ngân hàng có khả thi hay không, đồng thời qua đó cũng xác định được thời hạn hoàn trả nợ cho ngân hàng để xác định thời hạn cho vay hợp lý.

Bảo đảm - Insurance

Đây là yếu tố các ngân hàng xem là kém quan trọng nhất, bởi vì bất cứ ngân hàng nào cũng muốn số tiền vay của khách hàng được hoàn trả từ hiệu quả của 
phương án xin vay. Trong việc phân tích ngân hàng sẽ đánh giá về giá trị của tài sản thế chấp, cầm cố; về khả năng tiêu thụ và đặc biệt là tính pháp lý của chúng.

\subsubsection{Mô hình định lượng}

Theo Nguyễn Đăng Dờn (2011), lượng hoá rủi ro tín dụng là xác định mức rủi ro trên cơ sở các chỉ tiêu định tính và định lượng, làm căn cứ để xác định giới hạn tín dụng tối đa cho một khách hàng.

Nói cách khác, lượng hoá rủi ro tín dụng là việc xây dựng mô hình thích hợp để lượng hoá mức độ rủi ro mang lại từ phía khách hàng, từ đó xác định phần bù rủi ro và giới hạn tín dụng an toàn đối với một khách hàng, cũng như để trích lập dự phòng rủi ro.

\section{(1) Xếp hạng của Moody's và Standard\& Poor's}

Rủi ro tín dụng thường được thể hiện bằng việc xếp hạng trái phiếu và khoản cho vay. Việc xếp hạng này thường được thực hiện bởi một số dịch vụ xếp hạng, trong đó có Moody's và Standard\& Poor's là những dịch vụ tốt nhất. Đối với Moody’s xếp hạng cao nhất từ Aaa, với và Standard\& Poor's cao nhất là AAA. Sau đó xếp hạng giảm dần từ $\mathrm{Aa}, \mathrm{A}, \mathrm{Baa}, \mathrm{Ba}, \mathrm{B} \ldots$ (Moody's ) và $\mathrm{AA}, \mathrm{A}, \mathrm{BBB}, \mathrm{BB}, \mathrm{B} \ldots$ (Standard\& Poor's).

Những khách hàng được xếp hạng tín nhiệm ở bậc cao nhất Aaa, giảm dần qua $\mathrm{Aa}, \mathrm{A}$ và $\mathrm{Baa}$ (Theo tiêu chuẩn xếp hạng của Standard \& Poor's) là những trường hợp lượng hoá rủi ro ở mức bằng không, và tăng dần mức độ rủi ro đến Baa, là có thể được chấp nhận trong đầu tư và cho vay, mà không sợ rủi ro, hoặc rủi ro ở mức chấp nhận được.

Tương tự như vậy, theo tiêu chuẩn của Moody's, mức độ rủi ro tăng dần từ AAA đến mức chấp nhận được là $\mathrm{BBB}$. Những trường hợp còn lại, rủi ro cao, không nên đầu tư hoặc cho vay. 
Bảng 2.6 Mô hình xếp hạng của công ty Moody's và Standard\& Poor's

\begin{tabular}{|c|c|c|}
\hline $\begin{array}{l}\text { Nguồn tiêu } \\
\text { chuẩn }\end{array}$ & $\begin{array}{l}\text { Xếp } \\
\text { hạng }\end{array}$ & Tình trạng \\
\hline \multirow[b]{9}{*}{$\begin{array}{l}\text { Standard \& } \\
\text { Poor's }\end{array}$} & Ааa & $\begin{array}{l}\text { Chất lượng cao nhât, rủi ro thấp } \\
\text { nhất }\end{array}$ \\
\hline & $\mathrm{Aa}$ & Chất lượng cao \\
\hline & A & Chất lượng trên trung bình \\
\hline & Baa & Chất lượng trung bình \\
\hline & $\mathrm{Ba}$ & $\begin{array}{l}\text { Chất lượng trung bình mang yếu } \\
\text { tố đầu cơ }\end{array}$ \\
\hline & B & Chất lượng dưới trung bình \\
\hline & Caa & Chất lượng kém \\
\hline & $\mathrm{Ca}$ & Mang tính đầu cơ, có thể vỡ nợ \\
\hline & $\mathrm{C}$ & $\begin{array}{l}\text { Chất lượng kém nhất, triển vọng } \\
\text { xấu }\end{array}$ \\
\hline \multirow{9}{*}{ Moody's } & AAA & $\begin{array}{l}\text { Chất lượng cao nhất, rủi ro thấp } \\
\text { nhất }\end{array}$ \\
\hline & AA & Chất lượng cao \\
\hline & $\mathrm{A}$ & Chất lượng trên trung bình \\
\hline & BBB & Chất lượng trung bình \\
\hline & $\mathrm{BB}$ & $\begin{array}{l}\text { Chất lượng trung bình mang yếu } \\
\text { tố đầu cơ }\end{array}$ \\
\hline & B & Chất lượng dưới trung bình \\
\hline & $\mathrm{CCC}$ & Chất lương kém \\
\hline & $\mathrm{CC}$ & Mang tính đầu cơ, có thể vỡ nợ \\
\hline & $\mathrm{C}$ & $\begin{array}{l}\text { Chất lượng kém nhất, triển vọng } \\
\text { xấu }\end{array}$ \\
\hline
\end{tabular}

Nguồn: Nguyễn Đăng Dờn (2011) 


\section{(2) Mô hình điểm số tín dụng tiêu dùng}

Các yếu tố quan trọng liên quan đến khách hàng sử dụng mô hình cho điểm tín dụng bao gồm: hệ số tín dụng, tuổi đời, trạng thái tài sản, số người phụ thuộc, sở hữu nhà, điện thoại cố định, số tài khoản cá nhân, thời gian công tác...

Tổng số điểm tín dụng tiêu dùng theo 8 tiêu chí là 43 điểm (Max), thấp nhất là 9 điểm (Min). Giả sử ngân hàng xác định mức 28 điểm là ở mức rủi ro khá cao, cần từ chối cho vay, còn lại trên 28 điểm, được chia ra 6 bậc theo khung chính sách tín dụng với hạn mức cho vay tối đa như sau:

\section{Bảng 2.7 Bảng hạn mức tín dụng theo Mô hình điểm số tín dụng tiêu dùng}

\begin{tabular}{|l|l|}
\hline $\begin{array}{l}\text { Tổng số điểm của khách } \\
\text { hàng }\end{array}$ & Hạn mức tín dụng \\
\hline Từ 28 điểm trở xuống & Từ chối tín dụng \\
\hline $29-30$ điểm & 500 USD $(10,000,000$ VND) \\
\hline $31-33$ điểm & 1,000 USD $(20,000,000 \mathrm{VND})$ \\
\hline 34 - 36 điểm & 2,500 USD $(50,000,000 \mathrm{VND})$ \\
\hline 37 - 38 điểm & 3,500 USD $(70,000,000 \mathrm{VND})$ \\
\hline 39 - 40 điểm & 5,000 USD $(10,000,000 \mathrm{VND})$ \\
\hline $41-43$ điểm & $10,000,000 \mathrm{USD}(200,000,000 \mathrm{VND})$ \\
\hline
\end{tabular}

Nguồn: Nguyễn Đăng Dờn (2011)

(3) Mô hình điểm số tín dụng khách hàng cá nhân của FICO

Fair Isaac Corporation - FICO được thành lập từ năm 1956, FICO là tổ chức đầu tiên sử dụng toán học và kỹ thuật phân tích để giúp những doanh nghiệp đưa ra quyết định sáng suốt hơn.

Điểm số tín dụng của FICO được tính toán dựa trên một phương trình toán học, đánh giá nhiều thông tin tín dụng của khách hàng từ các báo cáo tín dụng do các tổ chức cung cấp. Sau đó, FICO so sánh những thông tin trên với những mẫu chuẩn mực được đúc kết từ hàng trăm ngàn báo cáo tín dụng trong quá khứ để đánh giá mức độ rủi ro tín dụng trong tương lai của khách hàng. 
Điểm số tín dụng FICO được dựa trên tình hình tín dụng của người vay tại một thời điểm, do đó, điểm số tín dụng của FICO sẽ thay đổi khi báo cáo tín dụng của người vay thay đổi.

Điểm số tín dụng của FICO được đánh giá từ $300-850$ điểm. Điểm số càng cao thì rủi ro tín dụng càng thấp. Điểm số dưới 620 thì được gọi là dưới chuẩn.

Bảng 2.8 Cấu trúc mô hình đánh giá điểm tín dụng của FICO:

\begin{tabular}{|l|l|l|}
\hline \multicolumn{1}{|c|}{ Tiêu chí đánh giá } & Giải thích tiêu chí & $\begin{array}{l}\text { Tỷ } \\
\text { trọng/tổng } \\
\text { điểm }\end{array}$ \\
\hline $\begin{array}{l}\text { Lịch trả nở } \\
\text { (Payment history) }\end{array}$ & $\begin{array}{l}\text { Thời gian trễ hạn càng dài và số tiền trễ hạn càng } \\
\text { cao thì điểm số tín dụng càng thấp }\end{array}$ & $35 \%$ \\
\hline $\begin{array}{l}\text { Dư nợ tại các tổ chức } \\
\text { tín dụng (Amounts } \\
\text { owned) }\end{array}$ & $\begin{array}{l}\text { Nợ qua nhiều so với mức cho phép, đặc biệt là đối } \\
\text { với thẻ tín dụng sẽ làm giảm điểm số tín dụng }\end{array}$ & $30 \%$ \\
\hline $\begin{array}{l}\text { Độ dài của lịch sử tín } \\
\text { dụng (Length of Credit } \\
\text { history)] }\end{array}$ & $\begin{array}{l}\text { Thông tin càng nhiều năm càng đáng tin cậy và } \\
\text { điểm số tín dụng sẽ càng cao }\end{array}$ & $15 \%$ \\
\hline $\begin{array}{l}\text { Số lần vay nợ mới } \\
\text { (New credit) }\end{array}$ & $\begin{array}{l}\text { Vay nợ thường xuyên bị xem là dấu hiệu có khó } \\
\text { khăn về tài chính nên điểm số tín dụng càng thấp. }\end{array}$ & $10 \%$ \\
\hline $\begin{array}{l}\text { Các loại tín dụng sử } \\
\text { dụng (Types of Credit } \\
\text { in use) }\end{array}$ & $\begin{array}{l}\text { Các loại nợ khác nhau sẽ được tính điểm số tín } \\
\text { dụng khác nhau }\end{array}$ & $10 \%$ \\
\hline
\end{tabular}

Nguồn: http://myfico.com

\subsubsection{Giới thiệu mô hình hồi quy Logistic}

Mô hình Logistic (Maddala, 1984) là mô hình toán học hồi quy, nghiên cứu sự phụ thuộc của một biến nhị phân (chỉ nhận 2 giá trị là 0 hoặc 1 ) vào các biến độc lập. Mô hình này được ứng dụng rộng rãi trong phân tích kinh tế nói chung và rủi ro tín dụng nói riêng. Cụ thể hơn, mô hình này có thể giúp Ngân hàng xác định khả năng khách hàng sẽ có rủi ro tín dụng (biến phụ thuộc) trên cơ sở sử dụng các nhân tố có ảnh hưởng đến khách hàng (biến độc lập).Nghĩa là, mô hình Logistic có thể ước lượng xác suất một khách hàng có rủi ro là nhiêu trực tiếp từ mẫu 


\section{Bảng 2.9 Cấu trúc dữ liệu các biến trong mô hình Logistic}

\begin{tabular}{|l|l|l|}
\hline Biến & Ký hiệu & Loại biến \\
\hline Phụ thuộc & $Y$ & Nhị phân \\
\hline Độc lập & $X_{i}$ & Liên tục hoặc rời rạc \\
\hline
\end{tabular}

Nguồn: Maddala (1984)

Y đóng vai trò là biến phụ thuộc và là biến nhị phân, chỉ có thể nhận hai giá trị là 0 hoặc 1 , cụ thể là:

Y= 0 Nếu khách hàng không trả được nợ (Có rủi ro tín dụng)

$\mathrm{Y}=1$ Nếu khách hàng trả được nợ (Không có rủi ro tín dụng)

+ Xi là biến độc lập, thể hiện các nhân tố ảnh hưởng đến khách hàng, ví dụ như giới tính, thu thập, tình trạng nhà,... đối với khách hàng cá nhân, hoặc ROE, ROA, vốn chủ sở hữu, ... đối với khách hàng doanh nghiệp.

$+\mathrm{Y}^{\wedge}$ là giá trị ước lượng của $\mathrm{Y}$, thu được khi hồi quy $\mathrm{Y}$ theo các biến độc lập.

Khi đó, xác suất một khách hàng trả được nợ (tức là xác suất $\mathrm{Y}=1$ ) được tính theo công thức sau, trong đó e là hằng số Euler (xấp xỉ 2.718) :

$$
P_{i}=\frac{1}{1+e^{-\left(\beta_{1}+\beta_{2} x_{2 i}+\ldots+\beta_{k} x_{k i}+u_{i}\right.}}
$$

Với

$$
Y=\beta_{0}+\beta_{1} X_{1}+\beta_{2} X_{2}+\ldots+\beta_{k} X_{k}
$$

Odds là tỷ lệ so sánh giữa hai xác suất: xác suất xảy ra sự việc và không xảy ra sự việc:

$O d d s=\frac{P_{i}}{1-P_{i}}=\frac{1+e^{Y i}}{1+e^{-Y i}}=e^{Y i}$

Lấy Log cơ số e của hàm Odds trên ta có dạng hàm hồi quy Logistic:

$$
\ln \frac{P_{i}}{1-P_{i}}=Y_{i}=\beta_{0}+\beta_{1} X_{1}+\beta_{2} X_{2}+\cdots+\beta_{k} X_{k}
$$

Để ước lượng $\beta$ ta có thể sử dụng các phần mềm như kinh tế lượng như Eviews, $\mathrm{R}$, Stata, SPSS, ... 


\section{Độ phù hợp của mô hình}

Để đo lường độ phù hợp của mô hình, trong phần mềm Eviews, ta sử dụng hệ số xác định mô hình $\mathrm{R}$-squared, thước đo này càng lớn, thể hiện sự phù hợp của mô hình càng cao. Nói cách khác, hệ số R-squared thể hiện tỷ lệ phần trăm ý nghĩa các biến được mô hình giải thích, hệ số này có giá trị lớn nhất là 1 , tức là mô hình giải thích đủ 100\% ý nghĩa các biến.

\section{Kiểm định ý nghĩa thống kê các hệ số}

Để kiểm định ý nghĩa thống kê của các hệ số, ta sử dụng kiểm định Wald Test. Mô hình hồi quy Binay Logistic cũng đòi hỏi các hệ số hồi quy phải khác 0 , nếu các hệ số đều bằng 0 thì mô hình sẽ trở nên vô hiệu. Do đó ta phải tiến hành kiểm định Wald Test với giả thiết $H_{0:} \beta_{k}=0$ với mức ý nghĩa cho trước.

\section{Kiểm định mức độ phù họ̣p tổng quát}

Để kiểm định mức độ phù hợp tổng quát của mô hình, ta cũng sử dụng kiểm định Wald Test với giả thiết $H_{0:} \beta_{1}=\beta_{2}=\cdots=\beta_{n}=0$ với mức ý nghĩa cho trước.

\section{Nhận xét về mô hình Binary Logistic}

Theo Lê Thị Minh Ngọc (2013). Úng dụng mô hình Logistic trong xếp hạng tín dụng khách hàng cá nhân tại ngân hàng thương mại cổ phần xuất nhập khẩu Việt Nam, Luận văn thạc sĩ kinh tế, Trường ĐH Kinh tế TP. HCM: Mô hình Logistic là một mô hình toán học định lượng do đó có những ưu điểm:

- Kỹ thuật đo lường, xác định được biến phụ thuộc $\mathrm{Y}$ - rủi ro tín dụng của khách hàng khá đơn giản.

- Mô hình còn thể hiện được tính khách quan, tính nhất quán, không phụ thuộc vào ý kiến chủ quan của cán bộ đánh giá xếp hạng khách hàng.

- Mô hình Lohistic lượng hoá được xác suất vỡ nợ của người vay, giúp phân loại và xếp hạng được khách hàng vay, khắc phục được những nhược điểm của mô hình định tính do đó sẽ giúp các ngân hàng kiểm soát được phần nào rủi ro trong công tác tín dụng.

Tuy nhiên mô hình này phụ thuộc nhiều vào cách phân loại nhóm khách hàng vay có rủi ro hay không có rủi ro. Mặt khác, mô hình đòi hỏi hệ thống thông tin đầy 
đủ, cập nhật của tất cả các khách hàng. Yêu cầu này rất khó thực hiện trong điều kiện thông tin chưa minh bạch của thị trường Việt Nam.

\subsubsection{Phân tích cơ sở lựa chọn mô hình hồi quy Binary Logisttic để phân tích rủi ro tín dụng khách hàng cá nhân không có tài sản đảm bảo tại VPBank}

Rủi ro tín dụng khách hàng cá nhân không có tài sản đảm bảo tại VPBank ngày càng diễn biến phức tạp, cho thấy mô hình đánh giá rủi ro khách hàng cá nhân hiện nay còn nhiều bất cập và cần phải có biện pháp cải tiến, nâng cao.

Hệ thống đánh giá rủi ro khách hàng cá nhân hiện nay tại VPBank phần lớn dựa vào yếu tố định tính, phụ thuộc nhiều vào sự chủ quan của cán bộ tín dụng, chưa có một công cụ tính toán được rủi ro một cách nhanh chóng và phù hợp. Bên cạnh đó, việc dựa vào thông tin tín dụng của trung tâm CIC để đánh giá mức độ rủi ro cũng không mang tính chính xác cao, do độ trễ của việc cập nhật thông tin. Do đó, cần thiết phải có một mô hình giúp tính toán cụ thể khả năng xảy ra rủi ro tín dụng.

Ở Việt Nam đã có nhiều nghiên cứu của các tác giả vận dụng mô hình Binary Logistic vào phân tích rủi ro tín dụng khách hàng cá nhân và cả doanh nghiệp, các mô hình này đều cho kết quả rất tốt, điều này chứng tỏ mô hình Binary Logistic khá phù hợp với điều kiện nghiên cứu tại Việt Nam.

Mô hình Binary Logistic là mô hình phù hợp nhất để trả lời câu hỏi có hay không. Cụ thể, cái chúng ta cần là một mô hình đưa ra được chính xác khả năng khách hàng có xảy ra rủi ro tín dụng hay không, có nên cho vay hay không, do đó tác giả quyết định chọn mô hình Binary Logistic cho nghiên cứu.

\section{Tóm lược chương 2}

Trong chương 2, mục tiêu chính là làm rõ hai vấn đề trọng tâm của nghiên cứu là lý thuyết về rủi ro tín dụng khách hàng cá nhân không có tài sản đảm bảo và mô hình hồi quy Logistic.

Về cơ sở lý thuyết, trong chương 2 đã làm rõ các khái niệm về tín dụng khách hàng cá nhân không có tài sản đảm bảo, và rủi ro tín dụng, các mô hình đo lường rủi ro tín dụng bao gồm mô hình định tính và mô hình định lượng. Từ đó xác định được các nhân tố cơ bản ảnh hưởng đến rủi ro tín dụng khách hàng cá nhân không có tài sản 
đảm bảo tại VPBank. Đây là nền tảng cho việc xây dựng các biến độc lập của mô hình nghiên cứu ở chương 3 cũng như đưa ra các giải pháp, kiến nghị ở chương 5.

Về mô hình hồi quy Logistic, trong chương 2 đã giới thiệu một cách cụ thể về mô hình, khả năng tính toán xác suất có thể trả nợ của khách hàng, cũng như nhận xét những ưu điểm khuyết điểm của mô hình. Từ đó phân tích cơ sở lựa chọn mô hình hồi quy Logistic để phân tích rủi ro tín dụng khách hàng cá nhân không có tài sản đảm bảo tại VPBank. 


\section{CHƯONG 3 \\ THIẾT KẾ NGHIÊN CỨU}

\subsection{Phương pháp nghiên cứu}

Phương pháp nghiên cứu chính của đề tài là phương pháp định lượng, dựa trên thực tiễn rủi ró tín dụng khách hàng cá nhân vay không có tài sản đảm bảo tại VPBank, tác giả nhận thấy ngoài việc tiến hành phân tích các yếu tố ảnh hưởng đến khả năng thanh toán của khách hàng, cùng với việc phân tích đánh giá quy trình tín dụng tại VPBank, xét thấy cần thiết phải có một công cụ, một mô hình giúp đo lường khả năng xảy ra rủi ro tín dụng một cách nhanh chóng, độ tin cậy cao và phù hợp với bối cảnh hoạt động tại VPBank.

Mô hình được lựa chọn phải đáp ứng được các yêu cầu căn bản như sau:

- Mô hình phải mang tính khách quan, khắc phục được những hạn chế trong đánh giá rủi ro tín dụng tại VPBank hiện nay chủ yếu dựa trên ý kiến chủ quan của cán bộ tín dụng.

- Mô hình phải có khả năng lượng hoá xác suất xảy ra rủi ro tín dụng của một khách hàng bằng một con số cụ thể, có độ tin cậy cao làm cơ sở giúp cán bộ dễ dàng ra quyết định tín dụng một cách nhanh chóng.

- Mô hình phải có tính ứng dụng cao, có thể sử dụng một cách dễ dàng, đơn giản, có thể đưa nhiều biến định tính, định lượng giúp xác định rủi ro một cách chính xác hơn.

Dựa trên các lý thuyết các mô hình định lượng rủ ro tín dụng và các công trình nghiên cứu của các tác giả trước, nhận thấy những ưu điểm của mô hình hồi quy Binary Logistic, nên tác giả quyết định sử dụng mô hình hồi quy Binary Logistic để đề xuất mô hình phân tích các nhân tố ảnh hưởng đến rủi ro tín dụng cá nhân không có tài sản đảm bảo như sau:

$$
\begin{aligned}
& \log _{e}\left[\frac{P(Y=1)}{P(Y=0)}\right]=\beta 1+\beta 2 \mathrm{X} 2+\beta 3 \mathrm{X} 3+\beta 4 \mathrm{X} 4+\beta 5 \mathrm{X} 5+\beta 6 \mathrm{X} 6+\beta 7 \mathrm{X} 7+\beta 8 \mathrm{X} 8+ \\
& \beta 9 \mathrm{X} 9+\beta 10 \mathrm{X} 10+\beta 11 \mathrm{X} 11+\beta 12 \mathrm{X} 12+\beta 13 \mathrm{X} 13+\beta 14 \mathrm{X} 14+\beta 15 \mathrm{X} 15+\beta 16 \\
& \mathrm{X} 16+\beta 17 \mathrm{X} 17+\beta 18 \mathrm{X} 18+\beta 19 \mathrm{X} 19
\end{aligned}
$$


Với Y: biến phụ thuộc, biến nhị nguyên với $Y=0$ nếu KH không có rủi ro tín dụng, $\mathrm{Y}=1$ nếu $\mathrm{KH}$ có rủi ro tín dụng

Xi: các biến độc lập

Bằng phương pháp định lượng xuyên suốt đề tài, tác giả sử dụng số liệu thứ cấp từ hồ sơ vay tiền của khách hàng tại VPBank, để chạy mô hình hồi quy logistic bằng phần mềm Eview, từ đó xác định các yếu tố ảnh hưởng đến rủi ro tín dụng khách hàng cá nhân không có tài sản đảm bảo tại VPBank.

\subsection{Quy trình nghiên cứu}

Bước 1: Sau khi nghiên cứu các lý thuyết về rủi ro tín dụng, các mô hình đo lường rủi ro, tác giả quyết định chọn mô hình hồi quy Binary Logistic với các biến như đã trình bày để đề xuất mô hình phân tích các nhân tố ảnh hưởng đến rủi ro tín dụng cá nhân không có tài sản đảm bảo.

Bước 2: Tiến hành thu thập số liệu từ hồ sơ của khách hàng vay tiền tại VPBank trong thời gian từ tháng 6/2012 đến tháng 12/2014. Khi đã có đầy đủ thông tin, tác giả sẽ tiến hành xử lý số liệu, lựa chọn những khách hàng có đầy đủ dữ liệu cần thiết, và mã hoá những biến định tính.

Kiểm tra mức độ tương quan giữa các biến định lượng để phát hiện các biến có mức độ tương quan chặt và có hướng xử lý.

Tiến hành các thống kê mô tả cơ bản.

Bước 3: Tiến hành ước lượng mô hình hồi quy Logistic với các biến. Tiến hành kiểm định sự cần thiết của các biến trong mô hình nếu biến đó có giá trị P-value lớn hơn một mức $\alpha$ cho trước. Loại bỏ các biến không có ý nghĩa trong mô hình và chọn ra mô hình phù hợp nhất.

Bước 4: Tiến hành kiểm định tính phù hợp chung của mô hình, và kiểm định ý nghĩa các biến của mô hình được lựa chọn. Nếu mô hình phù hợp, sẽ diễn dịch kết quả từ đó đưa ra những gợi ý chính sách nhằm ứng dụng mô hình cũng như góp phần hạn chế rủi ro tín dụng cá nhân vay không có tài sản đảm bảo tại VPBank. Nếu mô hình không phù hợp, phải xây dựng lại mô hình bắt đầu từ bước 2 . 


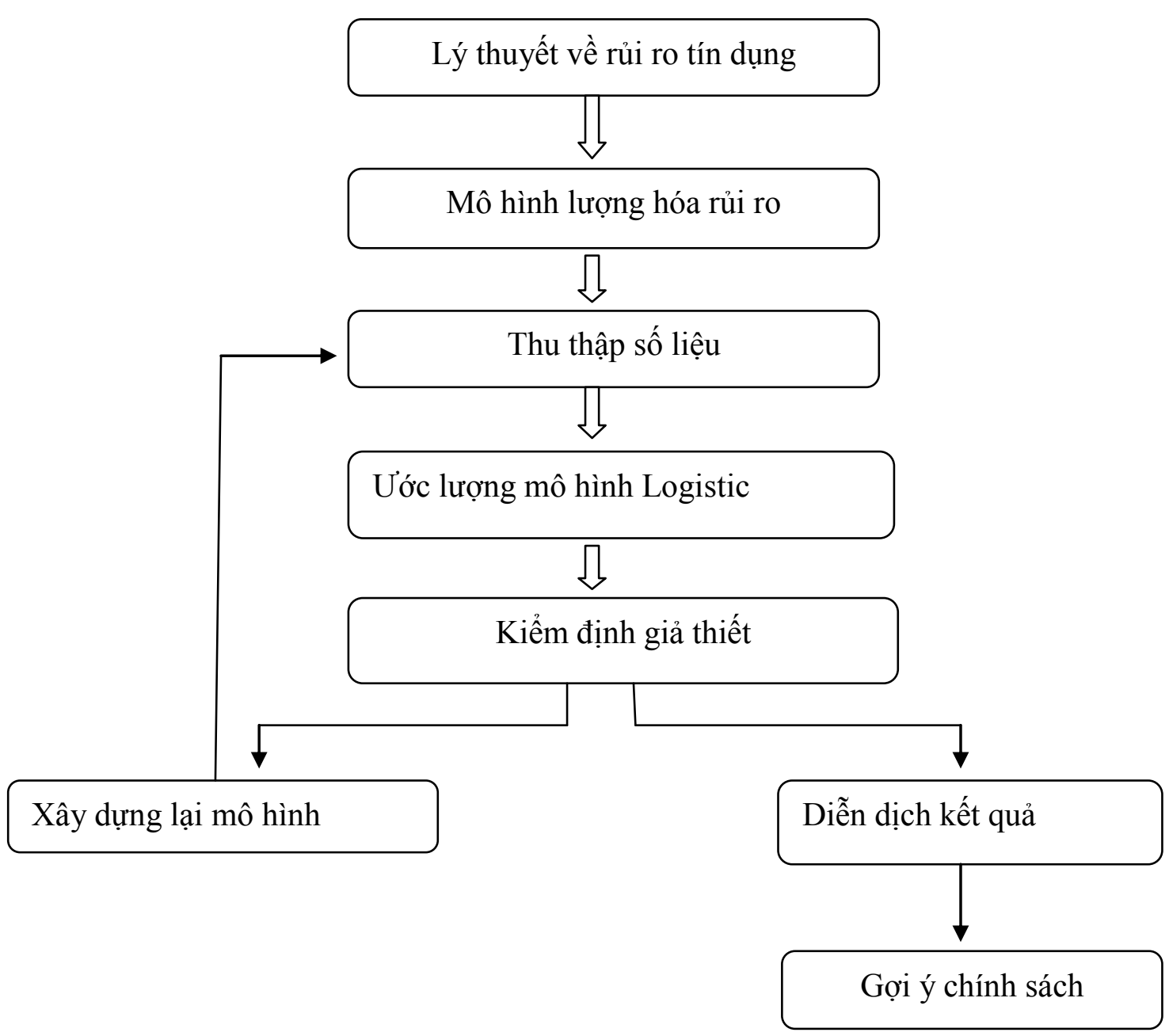

\section{Hình 3.1 So đồ quy trình nghiên cứu}

\subsection{Lấy mẫu nghiên cứu}

\subsubsection{Cách lấy mẫu}

Trong phạm vi nghiên cứu của đề tài, dữ liệu được thu thập từ hồ sơ vay vốn của khách hàng cá nhân tại VPBank. Dữ liệu được chọn lọc như sau:

- Khách hàng đã và đang quan hệ tín dụng tại VPBank trong khoảng thời gian từ 6/2012 - 31/12/2014, có đầy đủ thông tin cá nhân cũng như lịch sử thanh toán đã được xếp loại nhóm nợ.

- Lựa chọn ngẫu nhiên không phân biệt giới tính, vùng miền địa lý...

- Với mẫu dự kiến là 207 khách hàng cá nhân có vay không có tài sản đảm bảo tại ngân hàng VPBank. 


\subsubsection{Xác định cỡ mẫu}

Bảng 3.1 Số khách hàng được chọn nghiên cứu

\begin{tabular}{|c|r|r|r|r|}
\hline Năm & $\begin{array}{c}\text { Lượng hợp } \\
\text { đồng vay }\end{array}$ & \multicolumn{1}{c|}{ Lượng tiền vay } & \multicolumn{1}{|c|}{$\begin{array}{c}\text { Tỷ trọng } \\
\text { lựng tiền } \\
\text { vay }\end{array}$} & $\begin{array}{c}\text { Số lượng KH } \\
\text { được chọn }\end{array}$ \\
\hline 2012 & 4,545 & $126,632,590,725$ & $1 \%$ & 5 \\
\hline 2013 & 104,156 & $3,396,702,558,589$ & $27 \%$ & 27 \\
\hline 2014 & 336,602 & $8,959,603,093,041$ & $72 \%$ & 175 \\
\hline Tổng & 445,303 & $12,482,938,242,355$ & $100.00 \%$ & 207 \\
\hline
\end{tabular}

Nguồn: Báo cáo hoạt động kinh doanh năm 2012 - 2014 của bộ phận bán hàng

Trong phạm vi nghiên cứu từ 6/2012 - 31/12/2014, có tổng cộng 445.303 khách hàng cá nhân có vay tiền không tài sản đảm bảo tại VPBank được thể hiện qua bảng trên, tác giả chọn ngẫu nhiên 207 khách hàng theo tỷ trọng lượng tiền vay phân theo từng năm.

Các quan sát được lựa chọn là các khách hàng cá nhân vay tiền không có tài sản đảm bảo tại VPBank trên 6 tháng để đảm bảo rằng tất cả các mẫu được chọn đều đã phát sinh nợ phải thanh toán, như vậy mới có thể đánh giá rủi ro tín dụng một cách chính xác nhất.

Cỡ mẫu: Với số lượng quan sát tổng thể lớn hơn 200, thì việc lựa chọn cở mẫu theo công thức của Yamane (1967)

$$
n=\frac{N}{\left(1+N * e^{2}\right)}
$$

Trong đó: $\mathrm{N}$ là số quan sát tổng thể

e là sai số cho phép với mức ý nghĩa mong muốn là $\alpha=10 \%$. Số mẫu cần thực hiện tối thiểu là

$$
n=\frac{445,303}{\left(1+445,303 * 0.1^{2}\right)}=99.97755
$$

Với cỡ mẫu được chọn là 207 quan sát, đề tài đảm bảo được số lượng quan sát đủ đại diện cho tổng thể 445,303 khách hàng nghiên cứu. 


\subsection{Biện luận mô hình nghiên cứu}

\subsubsection{Xác định các biến phụ thuộc}

Sau khi xác định mô hình nghiên cứu đề nghị là mô hình hồi quy Logistic với phương trình:

$$
\begin{aligned}
& \log _{e}\left[\frac{P(Y=1)}{P(Y=0)}\right]=\beta 1+\beta 2 \mathrm{X} 2+\beta 3 \mathrm{X} 3+\beta 4 \mathrm{X} 4+\beta 5 \mathrm{X} 5+\beta 6 \mathrm{X} 6+\beta 7 \mathrm{X} 7+\beta 8 \\
& \mathrm{X} 8+\beta 9 \mathrm{X} 9+\beta 10 \mathrm{X} 10+\beta 11 \mathrm{X} 11+\beta 12 \mathrm{X} 12+\beta 13 \mathrm{X} 13+\beta 14 \mathrm{X} 14+\beta 15 \\
& \mathrm{X} 15+\beta 16 \mathrm{X} 16+\beta 17 \mathrm{X} 17+\beta 18 \mathrm{X} 18+\beta 19 \mathrm{X} 19
\end{aligned}
$$

Trong đó, Y là biến phụ thuộc, là biến nhị phân được xác định trên khả năng thanh toán của khách hàng cá nhân vay không có tài sản đảm bảo tại VPBank. Trong nghiên cứu này, tác giả chọn phương pháp xác định giá trị biến phụ thuộc dựa theo nghiên cứu của PGS. TS Trương Đông Lộc (2011) như sau:

Bảng 3.2 Giá trị của biến phụ thuộc trong mô hình Logistic

\begin{tabular}{|r|l|l|l|}
\hline STT & Phân loại khách hàng & Cách xác định & Giá trị biến \\
\hline 1 & Khách hàng không có rủi ro tín dụng & Nợ nhóm 1, 2 & Y=0 \\
\hline 2 & Khách hàng có rủi ro tín dụng & Nợ nhóm 3, 4, 5 & Y=1 \\
\hline \multicolumn{2}{|c|}{ Nguồn: Truoong Đông Lộc (2011) }
\end{tabular}

\subsubsection{Xác định các biến độc lập}

Sau khi xác định biến phụ thuộc, tác giả tiến hành chọn các biến độc lập dựa trên các yếu tố từ các lý thuyết và các công trình nghiên cứu trước, kết hợp với nguồn dữ liệu thực tế thu thập được tại VPBank. Do hạn chế về dữ liệu nghiên cứu, cũng như thực tế quy trình tín dụng tại VPBank, mô hình bỏ qua không xem xét các đặc điểm chủ quan về phía ngân hàng như: kinh nghiệm của cán bộ tín dụng, số lần kiểm tra, giám sát khoản vay trước khi chuyển sang nợ xấu..., cũng như bỏ qua không xem xét quan hệ tín dụng của khách hàng tại VPBank hoặc những tổ chức khác. Như vậy, mô hình chỉ tập trung xem xét các đặc điểm cá nhân, khả năng tài chính, và các đặc điểm của sản phẩm cho vay. 
Bảng 3.3 Giá trị các biến độc lập trong mô hình hồi quy Logistic

\begin{tabular}{|c|c|c|c|}
\hline $\begin{array}{l}\text { Biến } \\
\text { độc lập }\end{array}$ & Diễn giải & Ghi chú & $\begin{array}{l}\text { Kỳ vọng } \\
\text { dấu }\end{array}$ \\
\hline$X 2$ & Số tiền vay & & + \\
\hline$X 3$ & Thời hạn vay & & + \\
\hline$X 4$ & Lãi suất & & + \\
\hline$X 5$ & Số tiền phải trả hàng tháng & & + \\
\hline X6 & Trình độ học vấn & $\begin{array}{l}\text { X6=0 nếu trình độ KH dưới THPT/ X6=1 } \\
\text { cho trường hợp khác }\end{array}$ & - \\
\hline$X 7$ & Tình trạng hôn nhân & $\begin{array}{l}X 7=1 \text { nếu } \mathrm{KH} \text { đã kết hôn/ X7=0 cho các } \\
\text { trường hợp khác }\end{array}$ & - \\
\hline$X 8$ & Giới tính & $\mathrm{X} 8=0$ nếu $\mathrm{KH}$ là nữ $/ \mathrm{X} 8=1$ cho $\mathrm{KH}$ là nam & + \\
\hline$x 9$ & Tuổi & & + \\
\hline$X 10$ & Nghề nghiệp & $\begin{array}{l}X 19=1 \text { nếu KH làm việc hưởng } \\
\text { lương/X10=0 cho trường hợp khác }\end{array}$ & - \\
\hline$X 11$ & Tình trạng nhà ở & $\begin{array}{l}\text { X11=0 nếu KH thuê nhà/ X11=1 cho các } \\
\text { trường hợp khác }\end{array}$ & - \\
\hline$X 12$ & Thời gian sinh sống & & - \\
\hline$X 13$ & Số người phụ thuộc & & + \\
\hline$X 14$ & Thời gian công tác & & - \\
\hline$X 15$ & Thu nhập cá nhân & & - \\
\hline$X 16$ & Chi phí cá nhân & & + \\
\hline$X 17$ & Bảo hiểm khoản vay & $\begin{array}{l}\text { X17=0 nếu KH không chọn } \mathrm{BH} / \mathrm{X} 17=1 \\
\text { nếu KH có chọn mua BH khoản vay }\end{array}$ & - \\
\hline$X 18$ & Thu nhập gia đình & & - \\
\hline$X 19$ & Chi phí gia đình & & + \\
\hline
\end{tabular}


Đối với các biến độc lập này, tác giả chọn các phương pháp xác định:

- Dựa trên kết quả nghiên cứu của Vương Quân Hoàng (2006), Đinh Thị Huyền Thanh \& Stefanie Kleimeier (2006) đề đề xuất các biến mô tả đặc điểm cá nhân, khả năng tài chính của khách hàng.

- Dựa trên các mô hình đo lường rủi ro tín dụng $5 \mathrm{C}, 6 \mathrm{P}, \mathrm{CAMPARY}$ để đề xuất các biến mô tả đặc điệm sản phẩm cho vay

\subsubsection{Biện luận mô hình nghiên cứu}

Các biến X2, X3, X4, X5 là các biến mô tả đặc điểm sản phẩm cho vay. Các biến này cho biết các sản phẩm cho vay có phù hợp với khách hàng không, thiết kế, nghiên cứu chất lượng sản phẩm có làm cho chất lượng tín dụng tốt hơn không, từ đó giúp bộ phận phát triển sản phẩm có thể phát huy ưu điểm hoặc khắc phục những nhược điềm, giúp sản phẩm ra đời có thể góp phần hạn chế tối đa rủi ro tín dụng.

Các biến X6, X7, X8, X9, X10, X11, X12, X13, X14 là các biến mô tả đặc điểm cá nhân của khách hàng. Các biến này được xác định từ hồ sơ vay vốn ban đầu của khách hàng, kết hợp với kết quả thẩm định để cho thông tin xác thực nhất. Các biến này giúp ta xác định được tư cách, năng lực người vay, cũng như điều kiện, môi trường sinh sống và làm việc, xác định nguồn trả nợ vay... Cụ thể như sau:

Biến tình trạng học vấn (X6): Tác giả kỳ vọng mang dấu “-”, nghĩa là các khách hàng có trình độ học vấn cao thì kỳ vọng khả năng xảy ra rủi ro tín dụng sẽ thấp.

Biến tình trạng hôn nhân (X7): tác giả kỳ vọng mang dấu “-“, nghĩa là những khách hàng đã lập gia đình, cuộc sống ổn định thì kỳ vọng rủi ro tí dụng sẽ thấp hơn những khách hàng độc thân.

Biến giới tính (X8): tác giả kỳ vọng mang dấu “-“, nghĩa là đàn ông được kỳ vọng trả nợ tốt hơn phụ nữ. Vì theo Lea và ctg (1995) cho thấy rằng những người không trả nợ thường là phụ nữ hơn đàn ông. Và theo Xiao và ctg (1995) phát hiện ra rằng người đàn ông có thái độ hợp tác hơn phụ nữ trong việc sử dụng thẻ tín dụng và quan hệ với ngân hàng.

Biến tuổi (X9): tác giã kỳ vọng mang dấu “+”, nghĩ là tác giả kỳ vọng khách hàng trẻ tuổi sẽ trả nợ tốt hơn những khách hàng lớn tuối. Vì theo Adcock và ctg (1977) chỉ ra rằng có mối quan hệ tiêu cực giửa tuổi tác và sử dụng thẻ tín dụng. 
Biến nghề nghiệp (X10): tác giả kỳ vọng mang dấu “_-“, nghĩa là những khách hàng làm việc tại các tổ chức, công ty được nhận lương cố định hàng tháng được kỳ vọng sẽ ít rủi ro tín dụng hơn những khách hàng lao động tự do, kinh doanh buôn bán.

Biến tình trạng nhà ở (X11): tác giả kỳ vọng mang dấu “_“ nghĩa là những khách hàng thuê nhà được kỳ vọng không trả nợ tốt so với những khách hàng có nhà riêng hoặc sống cùng người thân, không phải trả tiền thuê nhà hàng tháng.

Biến thời gian sinh sống (X12): tác giả kỳ vọng mang dấu “"_“ có nghĩa là những khách hàng sinh sống lâu năm tại địa bàn được kỳ vọng sẽ ít rủi ro hơn so với những khách hàng có thời gian sinh sống tại địa chỉ hiện tại ngắn.

Biến số người phụ thuộc (X13): tác giả kỳ vọng mang dấu "+”, nghĩa là những khách hàng nào càng có nhiều người phụ thuộc thì khả năng xảy ra rủi ro tín dụng sẽ càng cao.

Biến thời gian công tác (X14): tác giả kỳ vọng mang dấu “-“, nghĩa là những khách hàng có thời gian công tác lâu năm, công việc ổn định và có thể thu nhập cao hơn thì sẽ ít có nguy cơ xảy ra rủi ro tín dụng.

Biến X15 kỳ vọng mang dấu “-“, X16 kỳ vọng mang dấu “+” là hai biến mô tả thu nhập và chi phí của khách hàng hàng tháng. Các biến này giúp xác định khả năng thanh toán nợ vay của khách hàng. Các biến này được bộ phận thẩm định tính toán cụ thể từ các giấy tờ chứng minh thu nhập của khách hàng và các khoản chi phí xác minh được trong quá trình thẩm định. Theo đó, tác giả kỳ vọng khách hàng có thu nhập hàng tháng cao, và chi phí hàng tháng thấp thì khả năng xảy ra rủi ro tín dụng sẽ thấp và ngược lại.

Để phù hợp với thực tiễn hoạt động cho vay tại VPB, tác giả có đưa thêm 3 biến mới vào mô hình nghiên cứu như sau:

Biến Bảo hiểm khoản vay (X17): do đối tượng khách hàng nghiên cứu là các khách hàng vay tiền mặt, không có tài sản đảm bảo, do đó biến tài sản đảm bảo đều bằng 0 nên không có ý nghĩa thống kê. Thay vào đó, đối với các khoản vay cá nhân không có tài sản đảm bảo này, VPBank chỉ có một hình thức bảo hộ khoản vay là tư vấn và khuyến khích các khách hàng mua bảo hiểm khoản vay từ công ty bảo hiểm đối tác. Nhưng hình thức mua bảo hiểm khoản vay này có thực sự hạn chế được rủi ro tín dụng hay không, đó là vấn đề cần được kiểm định thực tế lại, do đó tác giả đưa 
biến bảo hiểm khoản vay vào mô hình nghiên cứu với kỳ vọng biến mang dấu “_““. Nghĩa là khách hàng nào tự nguyện mua bảo hiểm khoản vay, thể hiện ý thức, trách nhiệm với khoản vay của mình, từ đó tác giả kỳ vọng khách hàng có khả năng ít xảy ra rủi ro tín dụng hơn

Biến Thu nhập gia đình (X17) kỳ vọng mang dấu “_- " và Chi phí gia đình (X18) kỳ vọng mang dấu "+”: do đặc điểm sinh sống của người Việt luôn gắn kết chặt chẽ với gia đình, do đó rủi ro một khoản vay cá nhân có thể chịu ảnh hưởng từ thu nhập và chi phí của gia đình. Đây cũng là một yếu tố để bộ phận thẩm định của VPBank ra quyết định cho vay, do đó tác giả quyết định đưa 2 biến này vào mô hình để kiểm định mức độ ảnh hưởng của 2 yếu tố này đến rủi ro tín dụng với kỳ vọng khách hàng nào có gia đình có mức thu nhập cao, chi phí thấp thì sẽ ít khả năng xảy ra rủi ro tín dụng.

\section{Tóm lược chương 3}

Trong chương này, tác giả trình bày phương pháp nghiên cứu, quy trình nghiên cứu, kết hợp với cơ sở lý thuyết được trình bày ở chương 2, tác giả đề xuất mô hình với 18 biến độc lập và một biến phụ thuộc đồng thời giải thích rõ ý nghĩa tính chất các biến cũng như kỳ vọng dấu mô hình của từng biến. Bên cạnh đó, chương 3 cũng trình bày rõ phương pháp xác định cỡ mẫu, cách chọn mẫu cũng như cách xác định các biến. Với mô hình được xây dựng, chương 4 sẽ cho kết quả nghiên cứu chính xác về ý nghĩa của các biến trong mô hình, hay nói cách khác là mức độ ảnh hưởng của các yếu tố đến rủi ro tín dụng khách hàng cá nhân không có tài sản đảm bảo tại VPBank. 


\section{CHƯONG 4 \\ KẾT QUẢ NGHIÊN CÚ̉U VÀ THẢO LUẬN}

\subsection{Giới thiệu chung về VPBank}

Ngân hàng TMCP Việt Nam Thịnh Vượng (Ngân hàng TMCP Các Doanh Nghiệp Ngoài Quốc Doanh trước đây) được thành lập ngày 12/8/1993. Sau 21 năm hoạt động, VPBank đã nâng vốn điều lệ lên 6,347 tỷ đồng, phát triển mạng lưới lên hơn 200 điểm giao dịch, với đội ngũ trên 7,000 cán bộ nhân viên.

Là thành viên của nhóm 12 ngân hàng hàng đầu Việt Nam (G12), VPBank đang từng bước khẳng định uy tín của một ngân hàng năng động, có năng lực tài chính ổn định và có trách nhiệm với cộng đồng. Để đạt được tầm nhìn đầy tham vọng, VPBank đã triển khai chiến lược tăng trưởng quyết liệt trong giai đoạn 2012 - 2017 với sự hỗ trợ của công ty tư vấn hàng đầu thế giới McKinsey.

Trong suốt 22 năm hoạt động, VPBank luôn có sự tăng trưởng ổn định qua các năm, thể hiện ở các chỉ tiêu tài chính cơ bản sau:

Bảng 4.1 Các chỉ tiêu tài chính cơ bản của VPBank

\begin{tabular}{|l|l|r|r|r|r|}
\hline Chỉ tiêu & $\begin{array}{l}\text { Đơn vị } \\
\text { tính }\end{array}$ & $\mathbf{2 0 1 1}$ & $\mathbf{2 0 1 2}$ & $\mathbf{2 0 1 3}$ & $\mathbf{2 0 1 4}$ \\
\hline Tổng tài sản & Tỷ đồng & 82,818 & 102,673 & 121,264 & 163,214 \\
\hline Vốn CSH & Tỷ đồng & 5,996 & 6,709 & 7,727 & 8,980 \\
\hline Huy động từ KH & Tỷ đồng & 29,412 & 59,514 & 83,844 & 108,354 \\
\hline Cho vay KH & Tỷ đồng & 29,184 & 36,903 & 52,474 & 78,379 \\
\hline Thu nhập hoạt động thuần & Tỷ đồng & 2,487 & 3,114 & 4,969 & 6,269 \\
\hline Lọi nhuận trước thuế & Tỷ đồng & 1,064 & 949 & 1,355 & 1,609 \\
\hline ROE & $\%$ & 14 & 11 & 14 & 15 \\
\hline Hệ số an toàn CAR & $\%$ & 11.9 & 12.5 & 12.5 & 11.4 \\
\hline
\end{tabular}

Nguồn: Báo cáo thường niên VPBank năm 2012, 2013 năm 2014 


\subsubsection{Lĩnh vực hoạt động}

\subsubsection{Lĩnh vực huy động vốn}

Là một trong 2 lĩnh vực hoạt động cơ bản mang lại lợi nhuận chủ yếu của ngân hàng, VPBank luôn có các sản phẩm tiết kiệm đa dạng, phù hợp với từng đối tượng khách hàng.

Đối với khách hàng cá nhân, VPB có khá nhiều hình thức huy động vốn với từng mức lãi suất khác nhau, cho từng điều kiện khách hàng bao gồm: chứng chỉ tiền gởi ghi danh dài hạn, tiết kiệm bảo toàn thịnh vượng, tiết kiệm gởi góp linh hoạt, tiết kiệm trả lãi cuối kỳ, tiết kiệm trả lãi định kỳ...

Đối với nhóm khách hàng doanh nghiệp, VPBank cung cấp chủ yếu 2 loại hình tiết kiệm không kỳ hạn và có kỳ hạn với lãi suất linh hoạt tuỳ từng điều kiện cụ thể.

\subsubsection{Linh viec cho vay}

Đây là lĩnh vực hoạt động chủ lực thứ 2 của ngân hàng, và VPBank cũng cung cấp rất nhiều sản phẩm tín dụng với lãi suất đa dạng, phù hợp với tất cả các đối tượng khách hàng.

Đối với khách hàng cá nhân, VPB cung cấp 2 hình thức tín dụng chủ yếu: cho vay có tài sản thế chấp và không có tài sản thế chấp.

- Cho vay không có tài sản thế chấp: bao gồm vay tiền mặt và vay thấu chi cá nhân.

- Cho vay có tài sản thế chấp: bao gồm cho vay hộ kinh doanh, cho vay mua nhà cá nhân, cho vay cá nhân xây dựng sửa chửa nhà, cho vay mua ô tô cá nhân...

Đối với khách hàng doanh nghiệp vừa và nhỏ, đây là nhóm khách hàng được VPBank ưu tiên đẩy mạnh nhất với rất nhiều chương trình ưu đãi cùng nhiều gói sản phẩm đa dạng. Tiêu biểu bao gồm: Chương trình tín dụng thông minh - SME SmartCredit, cho vay khách hàng Doanh nghiệp vừa và nhỏ được đảm bảo $100 \%$ bằng bất động sản (Business financing loan), chương trình "Vay mua ô tô - Cơn lốc siêu ưu đãi” dành cho Doanh nghiệp vừa và nhỏ; chương trình: "SME Success 2013 Chương trình cho vay ưu đãi dành cho khách hàng doanh nghiệp vừa và nhỏ năm 2013"; cho vay vốn lưu động trả góp; cho vay ngắn hạn theo món, cho vay theo hạn mức tín dụng ngắn hạn... 
Đối với khách hàng doanh nghiệp lớn, VPB hỗ trợ Tài trợ vốn lưu động ngắn hạn, cho vay cầm cố giấy tờ có giá và tài sản đảm bảo khác, cho vay hợp vốn, cho vay trung và dài hạn đầu tư tài sản cố định, dự án kinh doanh.

\subsubsection{Lĩnh vưc phát hành thẻ}

Trong lĩnh vực hoạt động thẻ, VPBank cung cấp 2 sản phẩm chính là thẻ thanh toán và thẻ tín dụng.

$>$ Thẻ thanh toán bao gồm

- Thẻ VP PASSPORT là loại Thẻ trả trước quốc tế của VPBank mang thương hiệu Visa.

- Thẻ thanh toán ảo (Smart Cash)

- Thẻ đồng thương hiệu Vietnam Airlines - VPBank Platinum MasterCard (VN Airline - VPB Platinum Debit) được thiết kế dành riêng cho khách hàng cao cấp

- Thẻ Quốc tế VPBank MasterCard mc2

$>$ Thẻ tín dụng bao gồm

- Thẻ tín dụng VPBank StepUP.

- Thẻ tín dụng VPLady với những đặc tính nổi trội được thiết kế riêng cho phụ nữ.

- Thẻ Quốc tế VPBank MasterCard mc2 dành cho Khách hàng trẻ

- Thẻ tín dụng Quốc tế MasterCard Platinum

\subsubsection{Các lĩnh vục khác}

Ngoài các hoạt động cơ bản của ngân hàng, VPBank còn cung cấp thêm nhiều dịch vụ tiện ích khác; tiêu biểu như sau:

Dịch vụ cá nhân: Dịch vụ nhận tiền Western Union trực tuyến; dịch vụ chi trả kiều hối Western Union; dịch vụ kiểm đếm ...

Bảo hiểm: bảo hiểm chăm sóc Phụ nữ - VP LADY CARE; bảo hiểm chăm sóc sức khỏe toàn diện - VP MEDI CARE ...

Dịch vụ thanh toán quốc tế: chuyển tiền đi quốc tế; chuyển tiền đến quốc tế; L/C nhập khẩu ...

Tài trợ thương mại: L/C trả chậm được phép thanh toán ngay - UPAS L/C; tài trợ dự án trọn gói; tài trợ Đại lý /Nhà phân phối ... 
Bảo lãnh: bảo lãnh thực hiện hợp đồng; bảo lãnh dự thầu; bảo lãnh nhận hàng...

Sản phẩm dịch vụ khác: dịch vụ Logistics; hợp đồng mua bán ngoại tệ hoán đổi; hợp đồng mua bán ngoại tệ giao ngay ...

\subsubsection{Cơ cấu tín dụng tại VPBank}

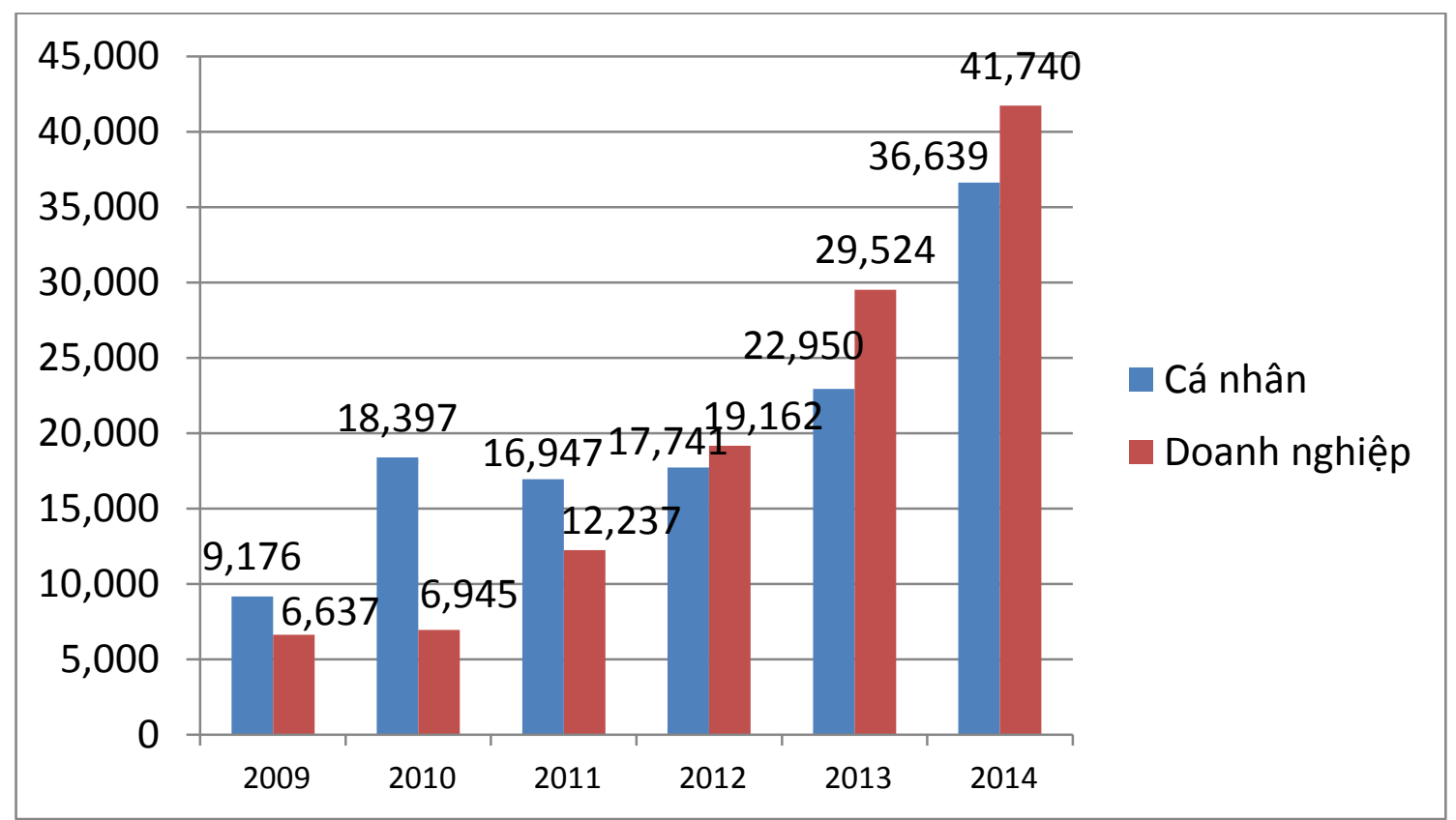

Nguồn: BCTN VPB năm 2013, 2014

\section{Hình 4.1 Biểu đồ cơ cấu tín dụng tại VPBank}

Dựa vào bảng các chỉ tiêu cơ bản của Vpbank qua các năm, ta thấy trong năm 2014, cho vay khách hàng đã đạt mức 78,379 tỷ VND, tăng 25,905 tỷ so với cuối năm 2013 (tương đương tăng 49.36\%). Mức tăng trưởng đáng kể này là thành quả của quá trình áp dụng nhiều chương trình và các gói tín dụng với lãi suất ưu đãi phù hợp với từng đối tượng khách hàng, trong từng thời điểm khác nhau.

Xét về cơ cấu tín dụng, ta thấy cho vay khách hàng cá nhân luôn có mức tăng trưởng ổn định qua các năm, riêng với cho vay doanh nghiệp, các năm gần đây đã có mức tăng trưởng vượt bậc đáng kể, trong đó chủ yếu là cho vay khách hàng doanh nghiệp vừa và nhỏ. Điều này hoàn toàn phù hợp với chiến lược và mục tiêu trở thành một trong 5 ngân hàng TMCP hàng đầu Việt Nam và một trong 3 ngân hàng TMCP bán lẻ hàng đầu Việt Nam vào năm 2017, theo đó VPBank sẽ tập trung vào phân khúc khách hàng cá nhân và SME. Để đạt được thành quả này, VPB đã cho ra đời rất nhiều chương trình ưu đãi dành riêng cho khách hàng cá nhân và khách hàng doanh nghiệp vừa và nhỏ trong suốt thời gian qua, điển hình như chương trình 1,000 tỷ đồng cho 
vay ưu đãi ngành Gạo và Thủy hải sản; dành 2,000 tỷ đồng hỗ trợ doanh nghiệp vừa và nhỏ; dành 100 triệu USD cho vay ưu đãi đối với doanh nghiệp xuất nhập khẩu ....

\subsubsection{Các sản phẩm cho vay khách hàng cá nhân}

Đối với khách hàng cá nhân, VPB cung cấp 2 hình thức tín dụng chủ yếu: cho vay có tài sản thế chấp và không có tài sản thế chấp.

- Cho vay không có tài sản thế chấp: bao gồm vay tiền mặt và vay thấu chi cá nhân.

- Cho vay có tài sản thế chấp: bao gồm cho vay hộ kinh doanh, cho vay mua nhà cá nhân, cho vay cá nhân xây dựng sửa chửa nhà, cho vay mua ô tô cá nhân...

Riêng với khách hàng vay không có tài sản đảm bảo, VPBank cung cấp các sản phẩm cho vay cho các đối tượng khách hàng cơ bản sau:

- Sản phẩm dành cho khách hàng làm việc tại các cơ quan, tổ chức, công ty được hưởng lương hàng tháng.

- Sản phẩm dành cho khách hàng tự kinh doanh hoặc lao động tự do.

- Sản phẩm dành cho khách hàng từng có lịch sử tín dụng tốt tại các tổ chức tín dụng khác

- Sản phẩm dành cho khách hàng từng có quan hệ tín dụng tại VPBank

- Sản phẩm dành cho khách hàng có mua bảo hiểm nhân thọ

- Sản phẩm dành cho khách hàng có hoá đơn điện/Internet đủ quy định và chứng minh thu nhập

\subsection{Thụ̣c trạng quản lý rủi ro tín dụng tại cá nhân không có tài sản đảm bảo tại VPBank}

\subsubsection{Quy trình quản lý rủi ro tại khâu thẩm định}

Đối với nhóm khách hàng cá nhân vay không có tài sản đảm bảo, không có tài sản thế chấp, VPBank hiện đang áp dụng quy trình thẩm định gồm các bước sau:

\section{Bước 1: Kiểm tra hồ sơ vay vốn của khách hàng}

Cán bộ thẩm định sẽ kiểm tra tính hợp pháp, hợp lệ của các giấy tờ trong hồ sơ vay vốn của khách hàng. Các giấy tờ có phù hợp với yêu cầu của sản phẩm mà khách hàng vay vốn không. Cán bộ cũng xem xét khả năng trả nợ của khách hàng để điều chỉnh lại khoản vay đề nghị nếu cần. 
Sau khi xem xét hồ sơ của khách hàng, cán bộ thẩm định sẽ tiến hành triểm tra lịch sử tín dụng của khách hàng trên $\mathrm{CIC}$, kiểm tra trùng lắp xem khách hàng đã có khoản vay nào khác tại VPBank chưa, kiểm tra khách hàng có nằm trong danh sách đen của VPBank không. Nếu các thông tin đều phù hợp sẽ chuyển sang bộ phận thẩm định qua điện thoại.

\section{Bước 2: Thẩm định qua điện thoại}

Bộ phận thẩm định qua điện thoại sẽ tiến hành xác minh các thông tin của khách hàng qua điện thoại, bao gồm: lấy thông tin từ khách hàng, từ nơi khách hàng làm việc, và từ người thân tham chiếu. Thông qua các thông tin có được, cán bộ thẩm định sẽ tiến hành liệt kê chi tiết các khoản thu nhập, chi phí của khách hàng và gia đình, từ đó tính toán khả năng thanh toán của khách hàng và điều chỉnh chi tiết khoản vay nếu cần.

\section{Bước 3: Thẩm định tại hiện trường}

Bộ phận thẩm định tại hiện trường sẽ tiến hành xác minh nơi cư trú thực tế của khách hàng và nơi làm việc, so sánh đối chiếu với các thông tin trên giấy tờ. Chụp hình lại các giấy tờ gốc nếu cán bộ thẩm định ở bước 1 và bước 2 có yêu cầu.

\section{Bước 4: Phê duyệt/Từ chối cho vay}

Từ các thông tin do cán bộ ở các bước cung cấp, cán bộ phê duyệt tín dụng sẽ tiến hành đối chiếu, so sánh, phân tích đánh giá nhiều yếu tố để ra quyết định tín dụng.

\section{Các trường hợp từ chối cho vay:}

- Khách hàng có quan hệ tín dụng tại 2 tổ chức tín dụng trở lên, có nợ cần chú ý hoặc có nợ xấu.

- Khách hàng từng đi tù, trại giam, trại cai nghiện

- Hộ khẩu của khách hàng đã có từ 3 người có quan hệ tín dụng tại VPBank

- Khách hàng cung cấp giấy tờ giả

- Nhà khách hàng sơ sài

- Khách hàng không làm đúng công việc như đã cung cấp trên đề nghị vay vốn

- Khách hàng không có nguồn thu nhập

- Khách hàng/ Người thân cung cấp thông tin giả 
- Nhà khách hàng đã chuyển đi nơi khác

- Nơi khách hàng làm việc rất nhỏ, không ổn định

- Người thân cung cấp thông tin xấu về khách hàng

- Nhà khách hàng đã bán

- Khách hàng không muốn gia đình, người thân biết về khoản vay

- Khách hàng không sống đúng tại địa chỉ đã cung cấp cho VPBank

- Thu nhập của khách hàng không ổn định

- Khách hàng bị phàn nàn, có phản ảnh xấu từ người thân, hàng xóm, đồng nghiệp

- Khách hàng nhờ người khác đóng vai người tham chiếu

- Số điện thoại khách hàng cung cấp cho VPBank là của người khác sử dụng, không phải của khách hàng.

\subsubsection{Quy trình quản lý rủi ro tại khâu giám sát sau cho vay và thu hồi nọ๋}

Sau khi giải ngân, bộ phận giám sát sau cho vay và thu hồi nợ sẽ tiến hành các bước:

_ 7 ngày sau khi giải ngân, bộ phận Wellcome Call sẽ gọi điện xác minh các thông tin khách hàng đã nhận được khoản vay chưa, khách hàng còn sinh sống tại địa chỉ đã cung cấp hay không, khách hàng còn sử dụng số điện thoại đã cung cấp không, khách hàng sử dụng vốn đúng mục đích hay không, khách hàng có bị ai lừa đảo đứng tên vay giùm hay không... Nhằm mục đích xác minh các thông tin một lần cuối, hỗ trợ thông tin cho nhân viên thu hồi nợ, phát hiện sớm các trường hợp gian lận, cố ý lừa đảo để chuyển cho bộ phận an ninh.

_ 7 ngày trước kỳ góp hàng tháng, hệ thống sẽ tự động gởi tin nhắn thông tin về thời gian và số tiền góp đến số điện thoại khách hàng đã cung cấp.

_ 5 ngày trước kỳ góp hàng tháng, nhân viên nhắc nợ sẽ gọi điện thoại cung cấp cho khách hàng các thông tin cần thiết để đóng tiền như thời gian, số tiền, địa điểm và cách thức thanh toán. Đối với trường hợp không liên lạc được với khách hàng, liên hệ với tất cả các số tham chiếu để lấy thông tin, nhanh chóng phát hiện các trường hợp gian lận, né tranh thanh toán để xử lý kịp thời.

_ Đối với khách hàng nợ nhóm 1, sẽ tiến hành song song 2 biện pháp nhắc nợ và thu hồi nợ tại nhà với từng giải pháp khác nhau dành cho từng đối tượng khách 
hàng. Thông báo hình thức phí phạt trể hạn và quy định chuyển thông tin lên CIC cho khách hàng rõ, tìm hiểu nguyên nhân khách hàng chưa thanh toán và cố gắng thuyết phục khách hàng.

__ Đối với các khách hàng nợ nhóm 2 , sau khi nhắc nhở và đến nhà nhiều lần, sẽ tiến hành gởi giấy báo nợ về nhà hoặc nơi làm việc của khách hàng. Trích tài khoản tại ngân hàng của khách hàng theo quy định trên hợp đồng, cơ cấu lại khoản nợ hoặc buộc thanh lý hợp đồng tuỳ từng trường hợp.

_ Đối với các khách hàng nợ nhóm 3 trở lên sẽ chuyển sang bộ phận thu hồi nợ pháp lý sẽ tiến hành phối hợp với chính quyền địa phương nơi khách hàng sinh sống để làm việc và gởi hồ sơ khởi kiện ra toà án nếu khách có dư nợ đủ điều kiện khởi tố.

\subsubsection{Phân tích rủi ro tín dụng khách hàng cá nhân không có tài sản đảm bảo tại VPBank}

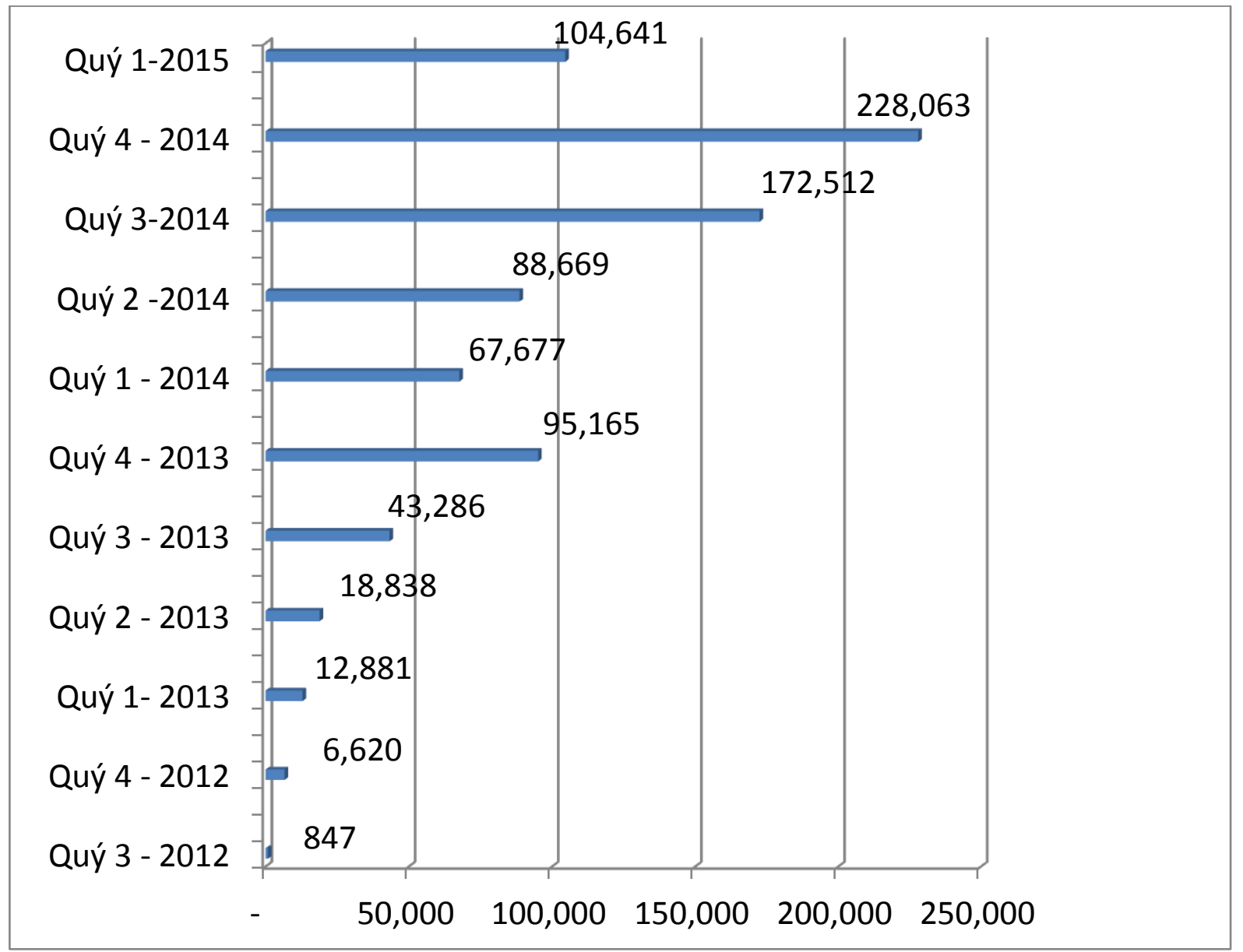

Nguồn: Tổng hợp tù báo cáo định kỳ tháng 6/2015 của bộ phận thẩm định

Hình 4.2 Diễn biến lượng hồ sơ vay cá nhân không có tài sản đảm bảo tại VPBank theo Quý 
Dựa vào biểu đồ tổng hợp lượng hồ sơ xin vay vốn từ 2012 đến 2015, ta thấy số lượng này có sự tăng trưởng vượt bậc đáng kể qua các năm, đỉnh điểm là những tháng cuối năm 2014, lượng hồ sơ vay vốn tăng lên đến hơn 200 ngàn trong quý 4. Các tháng cuối năm luôn là tháng có lượng hồ sơ xin vay vốn cao nhất, riêng tháng 2 thường rơi vào tết âm lịch nên nhu cầu vay vốn rơi xuống thấp nhất. Tuy nhiên, với lượng hồ sơ vay vốn tăng nhanh như trên, thì tỷ lệ hồ sơ được phê duyệt là bao nhiêu, đó là vấn đề cần phân tích tiếp theo.

Bảng 4.2 Diễn biền lượng hồ sơ vay cá nhân không có tài sản đảm bảo được duyệt tại VPBank theo quý

\begin{tabular}{|l|c|l|}
\hline Thời gian & Lượng hợp đồng mới & Lượng tiền giải ngân (VND) \\
\hline Quý 1-2015 & 62,378 & $1,653,662,872,756$ \\
\hline Quý 4-2014 & 134,147 & $3,552,187,715,659$ \\
\hline Quý 3 -2014 & 103,459 & $2,775,433,458,923$ \\
\hline Quý 2-2014 & 58,434 & $1,524,384,568,522$ \\
\hline Quý 1-2014 & 40,562 & $1,107,597,349,937$ \\
\hline Quý 4-2013 & 57,548 & $1,670,455,074,123$ \\
\hline Quý 3-2013 & 26,475 & $1,033,438,398,566$ \\
\hline Quý 2 -2013 & 12,417 & $464,780,848,950$ \\
\hline Quý 1-2013 & 7,716 & $228,028,236,950$ \\
\hline Quý 4 -2012 & 3,992 & $110,644,833,194$ \\
\hline Quý 3 - 2012 & 553 & $15,987,757,531$ \\
\hline
\end{tabular}

Nguồn: Tổng hợp tù báo cáo định kỳ tháng 6/2015 của bộ phận thẩm định

Với lượng hồ sơ vay vốn tăng trưởng mạnh và đều qua các năm như đã phân tích, ta thấy lượng hồ sơ được duyệt và tổng lượng tiền vay cũng tăng tương ứng, tuy tỷ lệ hồ sơ được duyệt lại có xu hướng giảm dần, thể hiện cụ thể qua biểu đồ sau: 


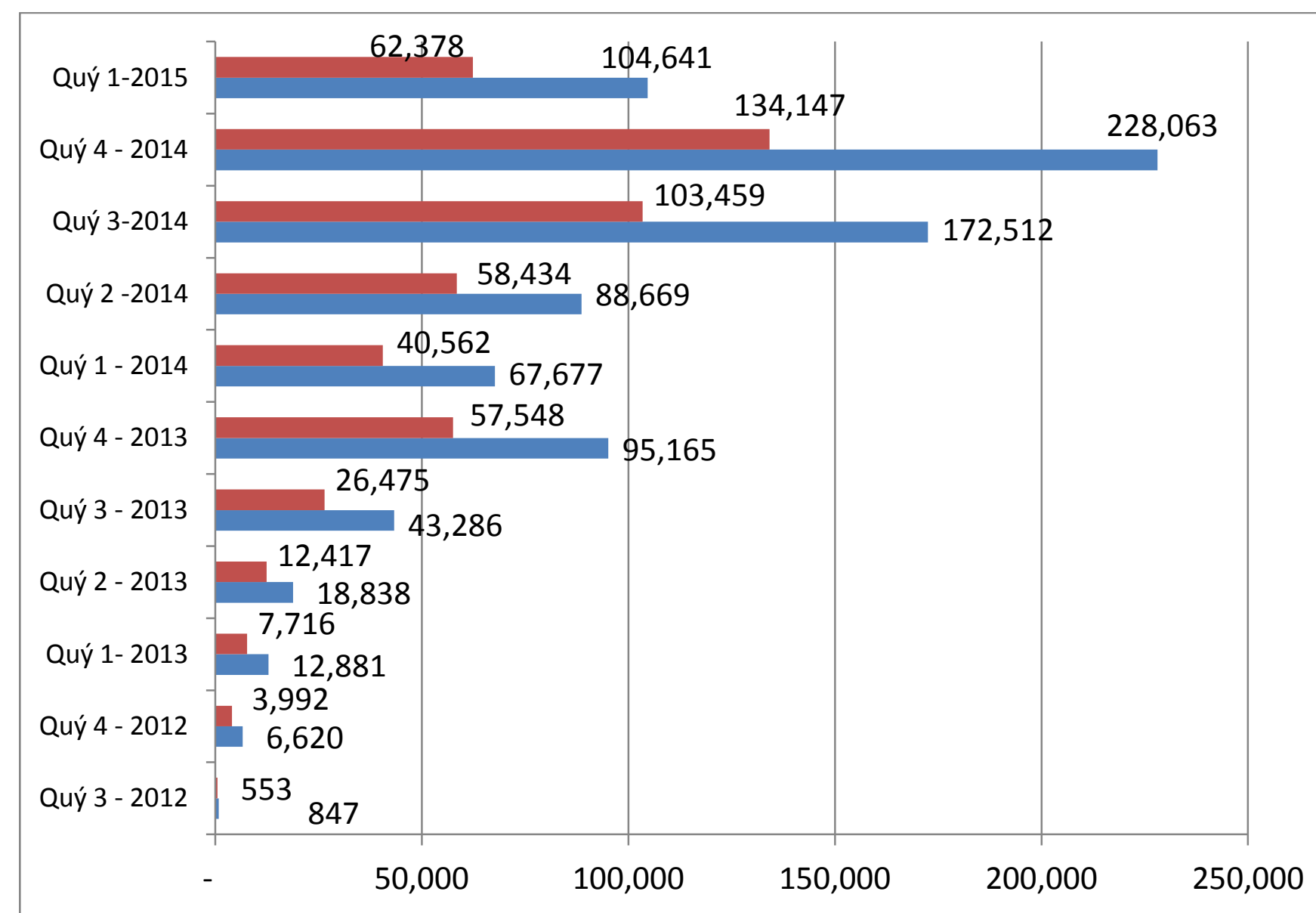

— Lượng hồ sơ được duyệt Lượng hồ sơ xin vay vốn

Nguồn: Tổng hợp tù báo cáo định kỳ tháng 6/2015 của bộ phận thẩm định

\section{Hình 4.3 Biểu đồ diễn biền lượng hồ sơ vay cá nhân không có tài sản đảm bảo được duyệt tại VPBank theo quý}

Dựa vào biểu đồ trên, ta thấy lượng hồ sơ được duyệt so với lượng hồ sơ khách hàng nộp vào ngày càng giảm, điều này có nghĩa là có một lượng lớn khách hàng không đáp ứng đủ điều kiện vay vốn, hoặc bị từ chối cho vay. Lượng hồ sơ bị từ chối càng lớn, càng ảnh hưởng đến uy tín và hình ảnh của ngân hàng đối với khách hàng. 
Bảng 4.3 Tỷ lệ hồ so bị từ chối phân theo lý do

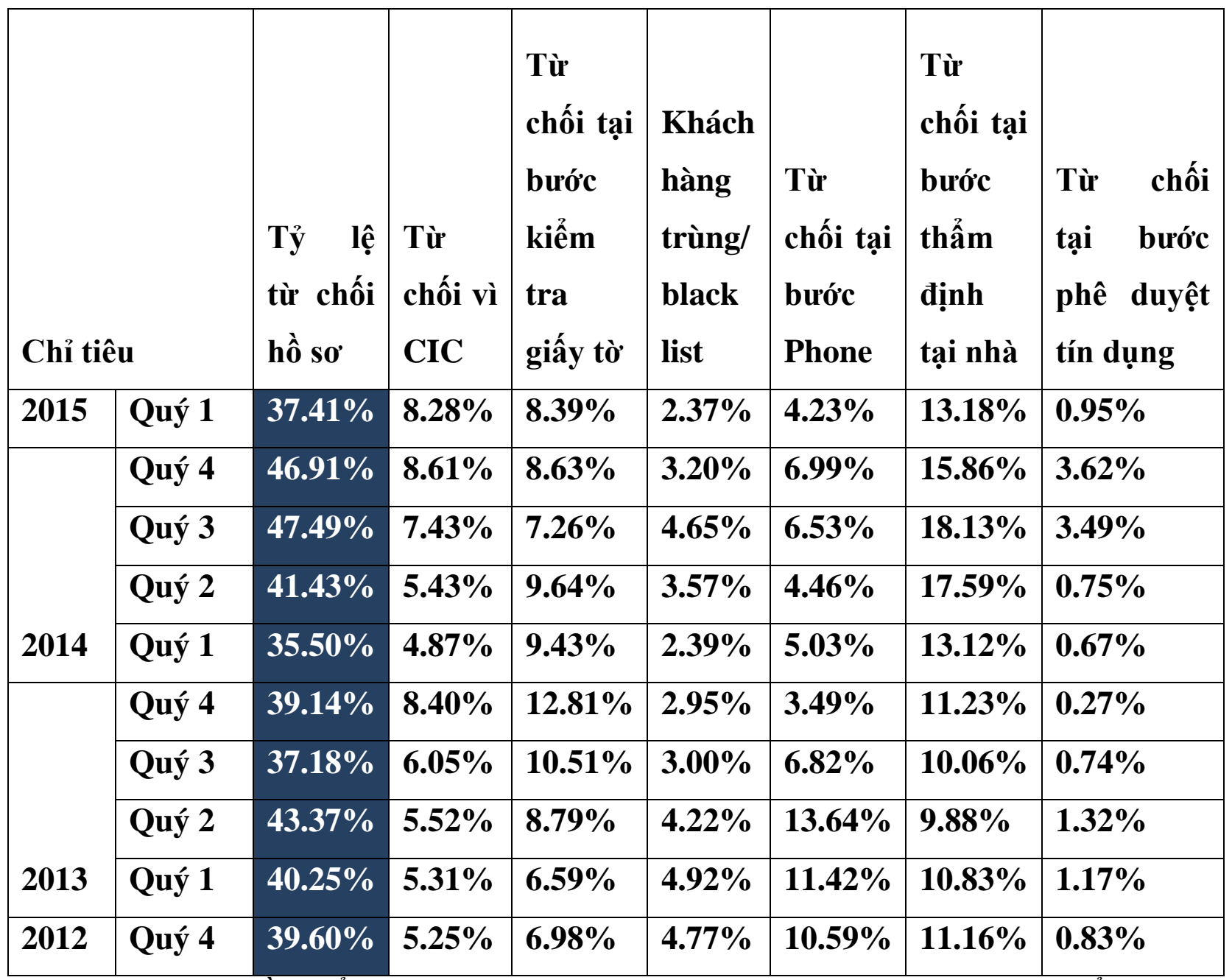

Nguồn: Tổng hợp tù báo cáo định kỳ tháng 6/2015 của bộ phận thẩm định

Dựa vào bảng tổng hợp tỷ lệ trên, ta thấy lượng hồ sơ bị từ chối dao động trong khoảng 35\% - 47\%, đây là một tỷ lệ tương đối cao và có xu hướng đang tăng dần trong những thời điểm gần đây. Điều này làm ảnh hưởng khá lớn đến uy tín của ngân hàng cũng như không ít rủi ro do từ chối những khách hàng tốt.

Để tìm hiểu nguyên nhân lượng khách hàng bị từ chối ngày càng cao, ta xem xét biểu đồ thể hiện tỷ lệ từ chối khách hàng tại từng bước thẩm định cụ thể như sau: 


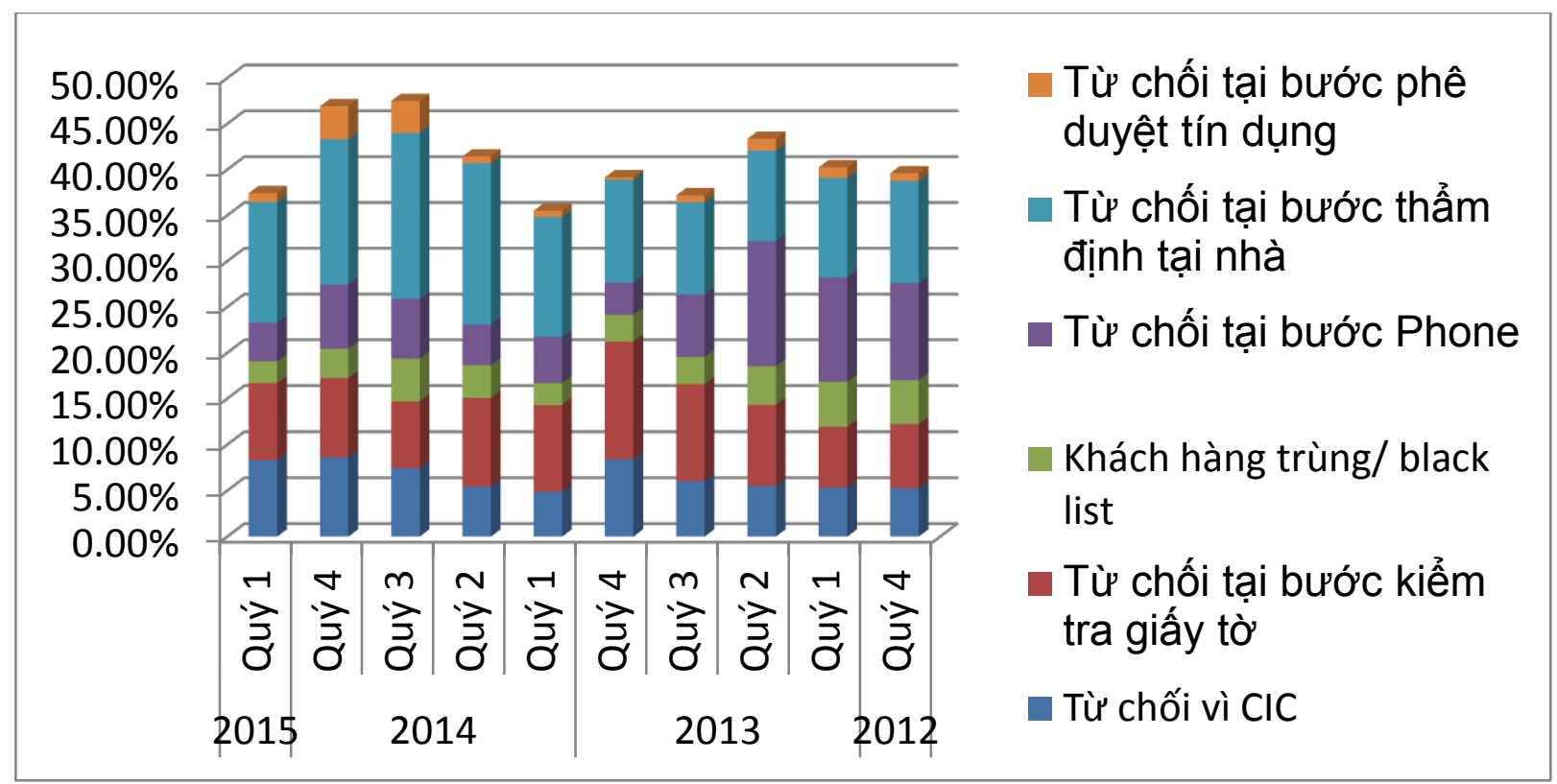

Nguồn: Tổng hợp tù báo cáo định kỳ tháng 6/2015 của bộ phận thẩm định

\section{Hình 4.4 Biều đồ diễn biến tỷ lệ khách hàng bị từ chối tín dụng theo lý do}

Dựa vào bảng phân tích lý do từ chối tín dụng, ta thấy một lượng lớn khách hàng bị từ chối tại bước thẩm định tại nhà, đây là khâu thẩm định quan trọng nhất trước khi chuyển đến bộ phận phê duyệt tín dụng. Một yếu tố khác cũng chiếm khá nhiều tỷ lệ hồ sơ bị từ chối là bước kiểm tra giấy tờ, bước kiểm tra này còn mang nhiều yếu tố chủ quan của nhân viên thẩm định, chưa có một khuôn mẫu chuẩn mực nhất định để đánh giá khách hàng.

Với tỷ lệ hồ sơ bị từ chối tương đối cao, nhưng mức độ rủi ro và chất lượng tín dụng thực tế như thế nào, ta sẽ tiếp tục phân tích.

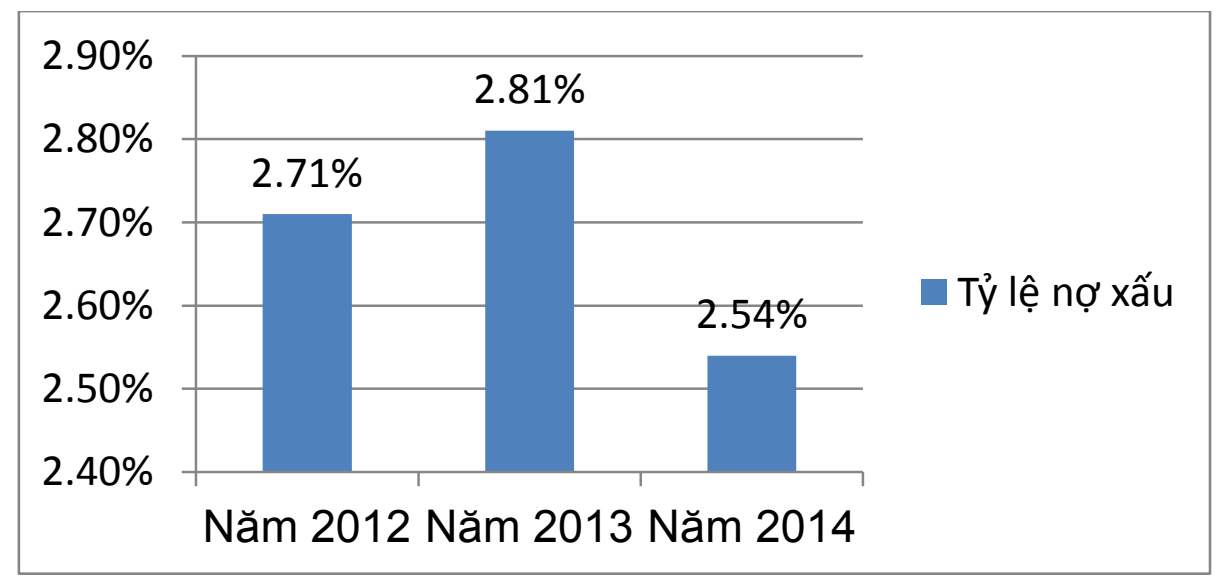

Nguồn: BCTN của VPbank năm 2012-2014

Hình 4.5 Biểu đồ tỷ lệ nọ xấu tại VPBank năm 2012-2014 
Xét trong 3 năm trở lại đây, tỷ lệ nợ xấu của VPBank luôn nằm trong vùng kiểm soát nhỏ hơn $3 \%$ tổng dư nợ. Trong năm 2014 , tỷ lệ này giảm từ $2.81 \%$ xuống còn $2.54 \%$, đây là một nổ lực đáng kể để giảm thiểu rủi ro của VPBank. Riêng mảng tín dụng khách hàng cá nhân vay không có tài sản đảm bảo có cơ cấu nợ như sau:

Bảng 4.4 Cơ cấu nọ của mảng tín dụng khách hàng cá nhân vay không có tài sản đảm bảo tại VPBank

Đơn vị tính (\%)

\begin{tabular}{|l|l|l|l|}
\hline & Năm 2012 & Năm 2013 & Năm 2014 \\
\hline Nợ nhóm 1 & 96.3 & 97 & 96.9 \\
\hline Nợ nhóm 2 & 1.6 & 1.1 & 1.3 \\
\hline Nợ nhóm 3 & 1.3 & 0.5 & 0.7 \\
\hline Nợ nhóm 4 & 0.3 & 0.6 & 0.2 \\
\hline Nợ nhóm 5 & 0.5 & 0.8 & 0.9 \\
\hline
\end{tabular}

Nguồn: Tổng hợp của tác giả tù báo cáo năm 2014 của phòng MIS

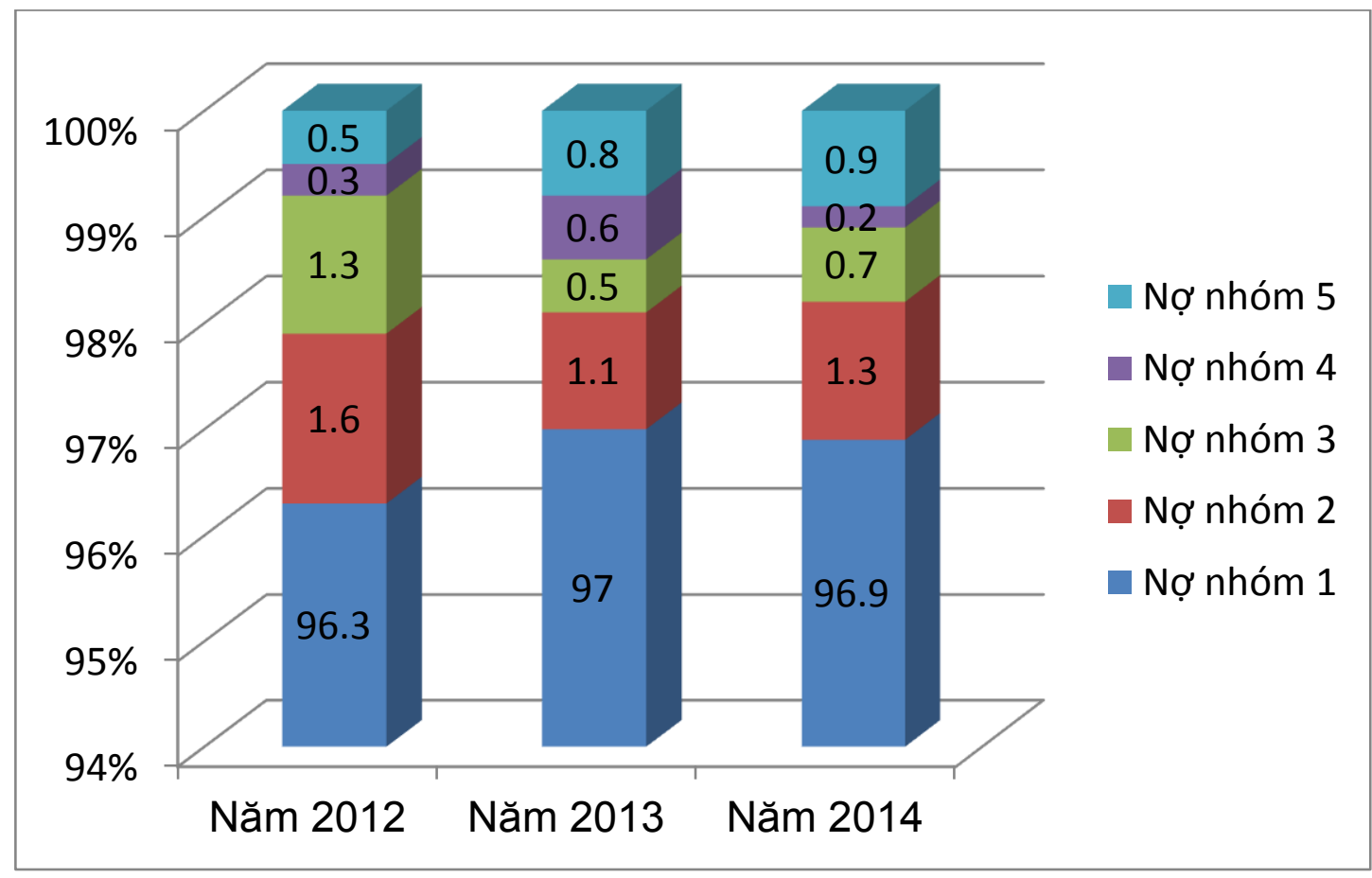

Nguồn: Tổng hợp của tác giả tù báo cáo năm 2014 của phòng MIS

Hình 4.6 Biểu đồ cơ cấu nhóm nọ của mảng tín dụng khách hàng cá nhân vay không có tài sản đảm bảo tại VPBank

Dựa vào cơ nhóm nợ của khách hàng cá nhân vay không có tài sản đảm bảo, ta thấy tỉ lệ nợ vẫn ở trong mức an toàn, tuy nhiên trong năm 2014, tỷ lệ nợ nhóm 1 có 
sự giảm nhẹ, trong khi nợ nhóm 5 tăng, đây là vấn đề cần lưu ý để có phương hướng giảm thiểu.

Xét về nguyên nhân không thu hồi được tiền, bao gồm cả gốc và lãi, tác giả thống kê được các nguyên nhân cơ bản như sau:

Bảng 4.5 Bảng tổng hợp nguyên nhân khách hàng không thanh toán

\begin{tabular}{|l|l|}
\hline Nguyên nhân không thu được tiền & Tỷ lệ \\
\hline KH bỏ trốn/bán nhà bỏ trốn & $6.53 \%$ \\
\hline $\begin{array}{l}\text { KH chờ lương, đợi mùa thu hoạch, chờ tiền của } \\
\text { người thân }\end{array}$ & $9.24 \%$ \\
\hline KH bận việc riêng & $4.05 \%$ \\
\hline KH đứng tên giùm/bị lừa & $2.32 \%$ \\
\hline KH bị tai nạn giao thông hiện đang khó khăn & $0.53 \%$ \\
\hline KH chết, cai nghiện, đi tù & $0.15 \%$ \\
\hline Khó khăn tài chính & $10.58 \%$ \\
\hline Không liên lạc/không tìm được KH & $20.81 \%$ \\
\hline Mất việc làm & $0.43 \%$ \\
\hline Nhà giải tỏa & $0.08 \%$ \\
\hline KH không hợp tác/từ chối thanh toán & $10.30 \%$ \\
\hline $\begin{array}{l}\text { Không gặp được khách hàng. Để lại lời nhắn/thư } \\
\text { báo }\end{array}$ & $34.98 \%$ \\
\hline Tổng & $100.00 \%$ \\
\hline
\end{tabular}

Nguồn: Tổng hợp của tác giả tù báo cáo của phòng thu hồi nọ năm 2014

Theo bảng tổng hợp trên, ta thấy đa phần các nguyên nhân không thu được tiền phần lớn từ phía khách hàng tránh né, bỏ trốn, bộ phận thu hồi nợ không gặp được khách hàng. Nhóm nguyên nhân cao tiếp theo là khách hàng gặp khó khăn về tài chính, không có khả năng thanh toán. Nếu xét theo nhóm nguyên nhân chủ quan/khách quan từ bộ phận thu hồi nợ, ta thấy có $17 \%$ trường hợp do nguyên nhân chủ quan, và $83 \%$ trường hợp là do nguyên nhân chủ quan khiến không thể thu hồi được nợ. 
Về nhóm nguyên nhân chủ quan như khách hàng bị cò lừa đứng tên giùm, không tìm thấy nhà khách hàng, khách hàng bán nhà bỏ trốn ... những nguyên nhân này thể hiện những khuyết điểm trong quá trình giám sát sau cho vay, các bộ phận không kịp thời phát hiện các trường hợp gian lận để xử lý sớm.

Đối với nhóm nguyên nhân chủ quan - nhóm nguyên nhân chiếm phần lớn các trường hợp không thu hồi được nợ, chủ yếu từ phía khách hàng tránh né, từ chối thanh toán, khó khăn tài chính ... những nguyên nhân này cho thấy rủi ro phát sinh từ trong quá trình thẩm định, quá trình xem xét đánh giá các yếu tố về tư cách khách hàng, thu nhập - chi phí, khả năng thanh toán...

Để hạn chế những rủi ro nói trên, bên cạnh quá trình phê duyệt tín dụng mang tính định tính truyền thống, bộ phận thẩm định cần có thêm một mô hình có thể xác định được tỷ lệ khả năng xảy ra rủi ro một cách nhanh chóng, có độ tin cậy cao và phù hợp với đối tượng khách hàng cụ thể của VPBank.

\subsubsection{Nhận định về quy trình quản lý rủi ro tín dụng khách hàng cá nhân vay không có tài sản đảm bảo tại VPBank}

\subsubsection{Nhũng thành công}

Phương pháp đánh giá rủi ro khách hàng hiện tại tại VPBank được thực hiện theo phương pháp định tính, đi sâu phân tích thực trạng tài chính cũng như tư cách cá nhân khách hàng, bộ phận thẩm định thu thập thông tin từ nhiều nguồn: hồ sơ vay vốn, thẩm định hiện trường, người thân tham chiếu, nơi làm việc... từ đó có được cái nhìn tổng quát để ra quyết định tín dụng.

Quy trình phê duyệt tín dụng được xử lý theo chiều ngang, chia nhỏ từng khâu thẩm định, do đó kết quả tín dụng không bị phụ thuộc vào một cán bộ duy nhất, tránh được tình trạng tiêu cực xảy ra. Bên cạnh đó, việc chia nhỏ quy trình thẩm định, mỗi bộ phận phụ trách một khâu thẩm định góp phần giúp quy trình phê duyệt nhanh hơn, chuyên nghiệp hơn.

Bộ phận bán hàng được tách biệt hẳn với bộ phận cấp tín dụng, góp phần hạn chế tình trạng chất lượng tín dụng giảm do chạy theo chỉ tiêu, doanh số.

Bộ phẩm kiểm soát sau cho vay được tổ chức và hoạt động một cách chuyên nghiệp, chia rõ từng khâu kiểm soát từng nhóm nợ riêng biệt. 


\subsubsection{Nhũng hạn chế}

Quy trình đánh giá rủi ro tín dụng khách hàng cá nhân tại VPBank chủ yếu dựa vào kinh nghiệm bản thân của cán bộ tín dụng, chưa được kiểm định trên dữ liệu thực tế và chất lượng tín dụng chủ yếu được đánh giá trên tỷ lệ nợ xấu.

Một số yếu tố để ra quyết định tín dụng chủ yếu dựa trên ý kiến khách quan của cán bộ tín dụng, chưa có một chuẩn mực nhất định để đánh giá các yếu tố như tình trạng nhà cửa của khách hàng, quan hệ của khách hàng với xã hội, đồng nghiệp... Mặt khác, lại có các quy định chung để ra quyết định tín dụng lại không phù hợp với tất cả các vùng miền địa lý, các doanh nghiệp địa phương khác nhau, dẫn đến việc phê duyệt tín dụng mang nhiều rủi ro hơn.

Bên cạnh ưu điểm từ việc chia nhỏ các khâu thẩm định, thì quy trình này lại mắc phải một nhược điểm đó là sự không đồng nhất ý kiến giữa các cán bộ tín dụng, điều này khiến khách hàng phải nhiều lần sửa chửa bổ sung hồ sơ, thẩm định nhiều lần, kéo dài thời gian phê duyệt và ảnh hưởng đến uy tín của ngân hàng.

\subsection{Kết quả nghiên cứu}

\subsubsection{Kết quả thống kê mẫu nghiên cứu}

\subsubsection{Phân tích cơ cấu mẫu nghiên cứu}

Dữ liệu nghiên cứu được lấy trên 207 khách hàng cá nhân vay không có tài sản đảm bảo tại tại VPBank từ 6/2012 đến 9/2014 trên tiêu chí lựa chọn ngẫu nhiên, không phân biệt vùng miền, nhóm nợ... Xét về cơ cấu mục đích sử dụng vốn, ta có bảng cơ cấu như sau:

Bảng 4.6 Cơ cấu mẫu theo mục đích sử dụng vốn

\begin{tabular}{|l|l|l|}
\hline Mục đích & Số lượng & Tỷ trọng \\
\hline Tiêu dùng & 89 & $43.00 \%$ \\
\hline Kinh doanh & 67 & $32.37 \%$ \\
\hline Chăn nuôi, trồng trọt & 27 & $13.04 \%$ \\
\hline Mua bất động sản, xây dựng & 13 & $6.28 \%$ \\
\hline Khác & 11 & $5.31 \%$ \\
\hline Tổng & 207 & $100.00 \%$ \\
\hline
\end{tabular}

Nguồn: Tổng hợp của tác giả tù hồ sơ vay của khách hàng 
Xét theo mục đích sử dụng vốn, ta thấy phần lớn khách hàng sử dụng vốn với mục đích tiêu dùng $43 \%$ và kinh doanh $32.37 \%$. Các khách hàng vay vốn với mục đích chăn nuôi trồng trọt chiếm 13.04\%, tỷ lệ tương đối nhỏ một phần là do đối tượng khách hàng này thường khó cung cấp được tài liệu chứng minh thu nhập với ngân hàng, đây là một nhóm khách hàng cần được thiết kế riêng những sản phẩm cho vay phù hợp để không đánh mất một lượng khách hàng phù hợp. Các khách hàng sử dụng vốn với mục đích mua bất động sản/xây dựng chiếm tỷ lệ khá thấp, do nhu cầu vay vốn của nhóm khách hàng này tương đối cao, nhưng không muốn thế chấp tài sản thì số lượng tiền được phê duyệt thường không đáp ứng đủ nhu cầu.

Trong 207 khách hàng được chọn, tất cả đều có đầy đủ các dữ liệu cần thiết về thông tin cá nhân, tình trạng tài chính... 207 khách hàng được chia làm 2 nhóm như đã trình bày ở các chương trước, nhóm 0 là nhóm khách hàng không có rủi ro tín dụng, nhóm 1 là nhóm khách hàng có rủi ro tín dụng.

\section{Bảng 4.7 Cơ cấu mẫu theo rủi ro tín dụng}

\begin{tabular}{|l|l|l|}
\hline Nhóm & Số lượng & Co cấu \\
\hline Nhóm 0 & 184 & $87.5 \%$ \\
\hline Nhóm 1 & 23 & $12.5 \%$ \\
\hline Tổng & 207 & $100 \%$ \\
\hline
\end{tabular}

Nguồn: Tổng hơp của tác giả tù hồ sơ vay của khách hàng

Với số mẫu nghiên cứu như trên, và 18 biến quan sát, ta thấy cở mẫu này đủ để đáp ứng đủ nguyên tắc phải có 5 quan sát cho mỗi biến nghiên cứu. Riêng nhóm 1 có 23 quan sát vẫn đáp ứng điều kiện lớn hơn 20 quan sát, tuy nhiên kích thước của nhóm 1 tương đối nhỏ, có thể ảnh hưởng đến kết quả nghiên cứu. 


\subsubsection{Phân tích mô tả mẫu nghiên cứu}

Các biến nghiên cứu có thống kê mô tả đơn giản như sau:

Bảng 4.8 Bảng thống kê mô tả các biến

\begin{tabular}{|l|l|l|l|l|l|l|}
\hline $\begin{array}{l}\text { Biến độc } \\
\text { lập }\end{array}$ & $\begin{array}{l}\text { Trung } \\
\text { bình }\end{array}$ & Trung vị & Maximum & Minimum & $\begin{array}{l}\text { Độ lệch } \\
\text { chuẩn }\end{array}$ & Số quan sát \\
\hline $\mathbf{X 2}$ & $27,556,750$ & $23,100,000$ & $70,000,000$ & $7,245,000$ & 1.2644547 & 207 \\
\hline $\mathbf{X 3}$ & 25.05797 & 24 & 36 & 9 & 7.886114 & 207 \\
\hline $\mathbf{X 4}$ & 0.038023 & 0.037533 & 0.070919 & 0.025009 & 0.007132 & 207 \\
\hline $\mathbf{X 5}$ & $1,728,471$ & $1,609,000$ & $3,555,000$ & 635,000 & 575836 & 207 \\
\hline $\mathbf{X 6}$ & 0.144928 & 0 & 1 & 0 & 0.352881 & 207 \\
\hline $\mathbf{X 7}$ & 0.695652 & 1 & 1 & 0 & 0.461246 & 207 \\
\hline $\mathbf{X 8}$ & 0.47343 & 0 & 1 & 0 & 0.500504 & 207 \\
\hline $\mathbf{X 9}$ & 34.90821 & 33 & 63 & 20 & 9.388398 & 207 \\
\hline $\mathbf{X 1 0}$ & 0.560386 & 1 & 1 & 0 & 0.497543 & 207 \\
\hline $\mathbf{X 1 1}$ & 0.584541 & 1 & 1 & 0 & 0.493996 & 207 \\
\hline $\mathbf{X 1 2}$ & 7.869565 & 4 & 49 & 0.1 & 8.832173 & 207 \\
\hline $\mathbf{X 1 3}$ & 1.232138 & 1 & 4.643609 & 0 & 1.114077 & 207 \\
\hline $\mathbf{X 1 4}$ & 4.728019 & 3.6 & 20 & 0.3 & 4.108006 & 207 \\
\hline $\mathbf{X 1 5}$ & 7.02029 & 6.1 & 24 & 3.4 & 3.424069 & 207 \\
\hline $\mathbf{X 1 6}$ & 3.155556 & 3 & 10 & 1 & 1.433258 & 207 \\
\hline $\mathbf{X 1 7}$ & 0.768116 & 1 & 1 & 0 & 0.423058 & 207 \\
\hline $\mathbf{X 1 8}$ & 10.43527 & 10 & 25 & 3.4 & 3.975882 & 207 \\
\hline $\mathbf{X 1 9}$ & 5.305314 & 6 & 11 & 1 & 1.776443 & 207 \\
\hline
\end{tabular}

Nguôn: Nghiên cứu của tác giả

\subsubsection{Kiểm định tự tương quan}

Xét về mức độ tương quan giữa các biến, theo lý thuyết nếu cặp biến có mức độ tương quan lớn hơn 0.8 sẽ dẫn đến hiện tượng đa cộng tuyến trong mô hình, để đánh giá tương quan này, ta quan sát ma trận hệ số tương quan (Phụ lục 05).

Trong ma trận hệ số tương quan, ta thấy có một cặp biến X15 và X16 có hệ số tương quan 0.857508 lớn hơn 0.8 , điều này cho thấy cặp biến này có sự tương quan chặt chẽ và có nguy cơ xảy ra hiện tượng đa cộng tuyến nếu đưa vào mô hình. Tuy 
nhiên theo Ramanathan, tính đa cộng tuyến có thể không có ảnh hưởng đến việc thực hiện dự báo của một mô hình và thậm chí có thể cải thiện dự báo. Như vậy, tác giả chọn hướng giải quyết vấn đề này là vẫn đưa 2 biến vào mô hình để tăng khả năng dự báo.

\subsubsection{Quy trình xây dựng mô hình tối ưu}

Để đưa ra kết quả nghiên cứu, tác giả tiến hành các bước sau:

\section{Bước 1: Chạy mô hình Logistic với tất cả 18 biến}

Chạy mô hình Logistic với tất cả 18 biến ta có kết quả như sau

Bảng 4.9 Kết quả hồi quy lần 1 với tất cả 18 biến

\begin{tabular}{|c|c|c|}
\hline Biến độc lập & Hệ số hồi quy & Mức ý nghĩa \\
\hline C & $1.84 \mathrm{E}+00$ & 0.749 \\
\hline $\mathrm{X} 2$ & $1.90 \mathrm{E}-07$ & 0.5652 \\
\hline $\mathrm{X} 3$ & -0.089497 & 0.7176 \\
\hline $\mathrm{X} 4$ & $6.82 \mathrm{E}+01$ & 0.5882 \\
\hline $\mathrm{X} 5$ & $-2.45 \mathrm{E}-06$ & 0.6153 \\
\hline $\mathrm{X} 6$ & -1.999097 & 0.2665 \\
\hline $\mathrm{X} 7$ & -4.450593 & 0.001 \\
\hline $\mathrm{X} 8$ & -3.052782 & 0.0132 \\
\hline $\mathrm{X} 9$ & 0.156806 & 0.0322 \\
\hline $\mathrm{X} 10$ & -4.107719 & 0.006 \\
\hline $\mathrm{X} 11$ & -2.338248 & 0.0838 \\
\hline $\mathrm{X} 12$ & -0.11474 & 0.3439 \\
\hline $\mathrm{X} 13$ & 1.085612 & 0.0314 \\
\hline $\mathrm{X} 14$ & -0.485022 & 0.0645 \\
\hline $\mathrm{X} 15$ & -0.4432 & 0.2984 \\
\hline $\mathrm{X} 16$ & 0.720568 & 0.371 \\
\hline $\mathrm{X} 17$ & -3.514451 & 0.0109 \\
\hline $\mathrm{X} 18$ & -0.93091 & 0.0065 \\
\hline $\mathrm{X} 19$ & 1.32727 & 0.0089 \\
\hline & & $N g 10$ \\
\hline
\end{tabular}

Nguồn: Nghiên cứu của tác giả 
Từ kết quả chạy mô hình, ta thấy giá trị xác suất của X3=0.7176 $>\alpha=5 \%$ chứng tỏ hệ số của biến này có thể bằng 0 , ta sẽ tiến hành kiểm định để loại bỏ biến này ra khỏi mô hình.

Để kiểm tra xem có thể loại bỏ biến X3 ra khỏi mô hình không, ta tiến hành kiểm định Wald Test:

Giả thiết:

Ho: $\mathrm{C}(3)=0$

H1: C(3)\#0

Kết quả kiểm định Wald Test

\section{Bảng 4.10 Kết quả kiểm định Wald Test để loại bỏ biến X3}

\begin{tabular}{|l|l|l|l|}
\hline \multicolumn{4}{|l|}{ Wald Test: } \\
\hline Equation: Untitled & Df & Probability \\
\hline Test Statistic & Value & 188 & 0.7180 \\
\hline t-statistic & -0.36166 & $(1,188)$ & 0.7180 \\
\hline F-statistic & 0.130798 & 1 & 0.7176 \\
\hline Chi-square & 0.130798 & 1 & Std. Err. \\
\hline Null Hypothesis: C(3)=0 & 0.247460 \\
\hline Null Hypothesis Summary: \\
\hline Normalized Restriction (=0) & Value \\
\hline C(3) & -0.089497 & \\
\hline Restrictions are linear in coefficients. \\
\hline
\end{tabular}

Nguồn: Nghiên cứu của tác giả

Kết quả kiểm định cho thấy, $\mathrm{C}(3)=0$ kiểm định $\mathrm{F}$-statistic có xác suất 0.7180 $>\alpha=5 \%$, và kiểm định Chi-square có xác suất $0.7176>\alpha=5 \%$, do đó ta chấp nhận giả thiết Ho, có thể bỏ biến X3 ra khỏi mô hình.

Sau khi loại bỏ biến X3 ra khỏi mô hình, ta tiến hành chạy mô hình với các biến còn lại. 


\section{Bước 2: Chạy lại mô hình Logistic bỏ bớt biến X3}

Chạy lại mô hình Logistic bỏ bớt biến X3 ta có kết quả như sau

Bảng 4.11 Kết quả hồi quy lần 2 sau khi bỏ bớt biến X3

\begin{tabular}{|l|r|r|}
\hline Biến độc lập & Hệ số hồi quy & Mức ý nghĩa \\
\hline C & 0.506531 & 0.9079 \\
\hline X2 & $7.89 \mathrm{E}-08$ & 0.5029 \\
\hline X4 & 49.77611 & 0.6613 \\
\hline X5 & $-8.35 \mathrm{E}-07$ & 0.6556 \\
\hline X6 & -2.07955 & 0.2438 \\
\hline X7 & -4.47162 & 0.0011 \\
\hline X8 & -3.01649 & 0.0132 \\
\hline X9 & 0.154399 & 0.035 \\
\hline X10 & -4.01079 & 0.0056 \\
\hline X11 & -2.44103 & 0.0651 \\
\hline X12 & -0.10468 & 0.3788 \\
\hline X13 & 1.119025 & 0.0233 \\
\hline X14 & -0.50395 & 0.0603 \\
\hline X15 & -0.41259 & 0.3266 \\
\hline X16 & 0.729541 & 0.378 \\
\hline X17 & -3.49331 & 0.0126 \\
\hline X18 & -0.94899 & 0.0067 \\
\hline X19 & 1.322097 & 0.0097 \\
\hline
\end{tabular}

Nguồn: Nghiên cứu của tác giả năm 2015

Từ kết quả chạy mô hình, ta thấy giá trị xác suất của $\mathrm{X} 4=0.6613>\alpha=5 \%$ chứng tỏ hệ số của biến này có thể bằng 0 , ta sẽ tiến hành kiểm định để loại bỏ biến này ra khỏi mô hình.

Để kiểm tra xem có thể loại bỏ biến X4 ra khỏi mô hình không, ta tiến hành kiểm định Wald Test. 
Giả thiết:

$$
\begin{aligned}
& \text { Ho: } \mathrm{C}(4)=0 \\
& \text { H1: } \mathrm{C}(4) \# 0
\end{aligned}
$$

Kết quả kiểm định Wald Test:

\section{Bảng 4.12 Kết quả kiểm định Wald Test để loại bỏ biến X4}

\begin{tabular}{|l|l|l|l|}
\hline \multicolumn{4}{|l|}{ Wald Test: } \\
\hline Equation: Untitled & Df & Probability \\
\hline Test Statistic & Value & 188 & 0.5888 \\
\hline t-statistic & 0.541518 & $(1,188)$ & 0.5888 \\
\hline F-statistic & 0.293242 & 1 & 0.5882 \\
\hline Chi-square & 0.293242 & 1 & Std. Err. \\
\hline Null Hypothesis: C(4)=0 & & 125.8862 \\
\hline Null Hypothesis Summary: & Value \\
\hline Normalized Restriction (=0) & 68.16965 & Nguồn: Nghiên cúu cúa tác giả \\
\hline C(4) &
\end{tabular}

Kết quả kiểm định cho thấy, $\mathrm{C}(4)=0$ kiểm định F-statistic có xác suất 0.5888 $>\alpha=5 \%$, và kiểm định Chi-square có xác suất $0.5882>\alpha=5 \%$, do đó ta chấp nhận giả thiết Ho, có thể bỏ biến X4 ra khỏi mô hình.

Sau khi loại bỏ biến X4 ra khỏi mô hình, ta tiến hành chạy lại mô hình Logistic với các biến còn lại 
Bước 3: Chạy lại mô hình Logistic bỏ bớt biến X3, X4

Chạy lại mô hình Logistic bỏ bớt biến X3, X4 ta có kết quả như sau

Bảng 4.13 Kết quả hồi quy lần 3 sau khi bỏ bớt biến X3, X4

\begin{tabular}{|l|r|r|}
\hline Biến độc lập & Hệ số hồi quy & Mức ý nghĩa \\
\hline C & 1.889197 & 0.5369 \\
\hline X2 & $5.83 \mathrm{E}-08$ & 0.5865 \\
\hline X5 & $-3.69 \mathrm{E}-07$ & 0.8105 \\
\hline X6 & -2.333344 & 0.1826 \\
\hline X7 & -4.572943 & 0.0008 \\
\hline X8 & -3.058272 & 0.0128 \\
\hline X9 & 0.163738 & 0.0208 \\
\hline X10 & -3.937472 & 0.0057 \\
\hline X11 & -2.510686 & 0.0594 \\
\hline X12 & -0.104852 & 0.3897 \\
\hline X13 & 1.110472 & 0.0226 \\
\hline X14 & -0.512302 & 0.0604 \\
\hline X15 & -0.414988 & 0.3304 \\
\hline X16 & 0.685338 & 0.3985 \\
\hline X17 & -3.247297 & 0.0093 \\
\hline X18 & -0.93926 & 0.0058 \\
\hline X19 & 1.332527 & 0.0083 \\
\hline
\end{tabular}

Nguồn: Nghiên cứu của tác giả

Từ kết quả chạy mô hình, ta thấy giá trị xác suất của $\mathrm{X} 5=0.8105>\alpha=5 \%$ chứng tỏ hệ số của biến này có thể bằng 0 , ta sẽ tiến hành kiểm định để loại bỏ biến này ra khỏi mô hình.

Để kiểm tra xem có thể loại bỏ biến X5 ra khỏi mô hình không, ta tiến hành kiểm định Wald Test: 
Giả thiết:

Ho: $\mathrm{C}(5)=0$

$\mathrm{H} 1: \mathrm{C}(5) \# 0$

Kết quả kiểm định Wald Test:

Bảng 4.14 Kết quả kiểm định Wald Test để loại bỏ biến X5

\begin{tabular}{|l|l|l|l|}
\hline \multicolumn{2}{|l|}{ Wald Test: } \\
\hline Equation: Untitled & Probability \\
\hline Test Statistic & Value & Df & 0.6159 \\
\hline t-statistic & -0.50251 & 188 & 0.6159 \\
\hline F-statistic & 0.252516 & $(1,188)$ & 0.6153 \\
\hline Chi-square & 0.252516 & 1 & \multicolumn{2}{|l|}{} \\
\hline Null Hypothesis: C(5)=0 & & Std. Err. \\
\hline Null Hypothesis Summary: & Value & 4.88 E-06 \\
\hline Normalized Restriction (=0) & -2.45 E-06 & Noû̀n. Nghiên cúu cúa tác giả \\
\hline C(5) &
\end{tabular}

Kết quả kiểm định cho thấy, $C(5)=0$ kiểm định F-statistic có xác suất 0.6159 > $\alpha=5 \%$, và kiểm định Chi-square có xác suất $0.6153>\alpha=5 \%$, do đó ta chấp nhận giả thiết Ho, có thể bỏ biến X5 ra khỏi mô hình.

Sau khi loại bỏ biến X5 ra khỏi mô hình, ta tiến hành chạy lại mô hình với các biến còn lại 


\section{Bước 4: Chạy lại mô hình Logistic bỏ bớt biến X3, X4, X5}

Chạy lại mô hình Logistic bỏ bớt biến X3, X4, X5 ta có kết quả như sau

Bng 4.15 Kết quả hồi quy lần 3 sau khi bỏ bớt biến X3, X4, X5

\begin{tabular}{|l|r|r|}
\hline Biến độc lập & Hệ số hồi quy & Mức ý nghĩa \\
\hline C & 1.508858 & 0.5608 \\
\hline X2 & $4.86 \mathrm{E}-08$ & 0.6252 \\
\hline X6 & -2.32247 & 0.1893 \\
\hline X7 & -4.57714 & 0.0008 \\
\hline X8 & -2.98868 & 0.0122 \\
\hline X9 & 0.16387 & 0.0187 \\
\hline X10 & -3.90252 & 0.0054 \\
\hline X11 & -2.48476 & 0.0562 \\
\hline X12 & -0.09952 & 0.3957 \\
\hline X13 & 1.112169 & 0.0219 \\
\hline X14 & -0.5048 & 0.056 \\
\hline X15 & -0.44669 & 0.2812 \\
\hline X16 & 0.702481 & 0.3833 \\
\hline X17 & -3.21457 & 0.0097 \\
\hline X18 & -0.95156 & 0.0047 \\
\hline X19 & 1.354712 & 0.0068 \\
\hline
\end{tabular}

Nguồn: Nghiên cứu của tác giả

Từ kết quả chạy mô hình, ta thấy giá trị xác suất của X2=0.6252> $\alpha=5 \%$ chứng tỏ hệ số của biến này có thể bằng 0 , ta sẽ tiến hành kiểm định để loại bỏ biến này ra khỏi mô hình.

Để kiểm tra xem có thể loại bỏ biến X2 ra khỏi mô hình không, ta tiến hành kiểm định Wald Test: 
Giả thiết: $\quad$ Ho: $\mathrm{C}(2)=0$

$$
\mathrm{H} 1: \mathrm{C}(2) \# 0
$$

Kết quả kiểm định Wald Test:

Bảng 4.16 Kết quả kiểm định Wald Test để loại bỏ biến X2

\begin{tabular}{|l|l|l|l|}
\hline \multicolumn{4}{|l|}{ Eald Test: } \\
\hline Test Statistic & Value & Df & Probability \\
\hline t-statistic & 0.575077 & 188 & 0.5659 \\
\hline F-statistic & 0.330713 & $(1,188)$ & 0.5659 \\
\hline Chi-square & 0.330713 & 1 & 0.5652 \\
\hline Null Hypothesis: C(2)=0 & & \\
\hline Null Hypothesis Summary: & Value & Std. Err. \\
\hline Normalized Restriction (=0) & 1.90 E-07 & 3.30 E-07 \\
\hline C(2) & Restrictions are linear in coefficients. \\
\hline
\end{tabular}

Nguồn: Nghiên cưu của tác giả

Kết quả kiểm định cho thấy, $\mathrm{C}(2)=0$ kiểm định $\mathrm{F}$-statistic có xác suất 0.5659 > $\alpha=5 \%$, và kiểm định Chi-square có xác suất $0.5652>\alpha=5 \%$, do đó ta chấp nhận giả thiết Ho, có thể bỏ biến X2 ra khỏi mô hình.

Sau khi loại bỏ biến X2 ra khỏi mô hình, ta tiến hành chạy lại mô hình với các biến còn lại 


\section{Bước 5: Chạy lại mô hình Logistic bỏ bớt biến X3, X4, X5, X2}

Chạy lại mô hình Logistic bỏ bớt biến X3, X4, X5, X2 ta có kết quả như sau

Bảng 4.17 Kết quả hồi quy lần 5 sau khi bỏ bớt biến X3, X4, X5, X2

\begin{tabular}{|l|r|r|}
\hline Biến độc lập & Hệ số hồi quy & Mức ý nghĩa \\
\hline C & 2.011678 & 0.3974 \\
\hline X6 & -2.26597 & 0.2016 \\
\hline X7 & -4.40555 & 0.0006 \\
\hline X8 & -2.9783 & 0.0126 \\
\hline X9 & 0.163238 & 0.0179 \\
\hline X10 & -3.84351 & 0.0053 \\
\hline X11 & -2.33086 & 0.0626 \\
\hline X12 & -0.11978 & 0.2738 \\
\hline X13 & 1.128638 & 0.0189 \\
\hline X14 & -0.55462 & 0.0331 \\
\hline X15 & -0.39867 & 0.3084 \\
\hline X16 & 0.938856 & 0.163 \\
\hline X17 & -3.31486 & 0.0076 \\
\hline X18 & -1.00307 & 0.0031 \\
\hline X19 & 1.401279 & 0.0052 \\
\hline
\end{tabular}

Nguồn: Nghiên cưu của tác giả

Từ kết quả chạy mô hình, ta thấy giá trị xác suất của X15=0.3084> $\alpha=5 \%$ chứng tỏ hệ số của biến này có thể bằng 0 , ta sẽ tiến hành kiểm định để loại bỏ biến này ra khỏi mô hình.

Để kiểm tra xem có thể loại bỏ biến X15 ra khỏi mô hình không, ta tiến hành kiểm định Wald Test: 
Giả thiết:

Ho: $\mathrm{C}(15)=0$

H1: C(15)\#0

Kết quả kiểm định Wald Test

Bảng 4.18 Kết quả kiểm định Wald Test để loại bỏ biến X15

\begin{tabular}{|c|c|c|c|}
\hline \multicolumn{4}{|l|}{ Wald Test: } \\
\hline \multicolumn{4}{|c|}{ Equation: Untitled } \\
\hline Test Statistic & Value & Df & Probability \\
\hline t-statistic & -1.039934 & 188 & 0.2997 \\
\hline F-statistic & 1.081463 & $(1,188)$ & 0.2997 \\
\hline Chi-square & 1.081463 & 1 & 0.2984 \\
\hline \multicolumn{4}{|c|}{ Null Hypothesis: $C(15)=0$} \\
\hline \multicolumn{4}{|c|}{ Null Hypothesis Summary: } \\
\hline \multicolumn{2}{|c|}{ Normalized Restriction $(=0)$} & Value & Std. Err. \\
\hline \multicolumn{2}{|l|}{$\mathrm{C}(15)$} & -0.4432 & 0.426181 \\
\hline
\end{tabular}

Nguồn: Nghiên cứu của tác giả

Kết quả kiểm định cho thấy, $\mathrm{C}(15)=0$ kiểm định $\mathrm{F}$-statistic có xác suất $0.2997>\alpha$ $=5 \%$, và kiểm định Chi-square có xác suất $0.2984>\alpha=5 \%$, do đó ta chấp nhận giả thiết Ho, có thể bỏ biến X15 ra khỏi mô hình.

Sau khi loại bỏ biến X15 ra khỏi mô hình, ta tiến hành chạy lại mô hình với các biến còn lại 
Bước 6: Chạy lại mô hình Logistic bỏ bớt biến X3, X4, X5, X2, X15

Chạy lại mô hình Logistic bỏ bớt biến X3, X4, X5, X2, X15 ta có kết quả như sau

Bảng 4.19 Kết quả hồi quy lần 6 sau khi bỏ bớt biến X3, X4, X5, X2, X15

\begin{tabular}{|l|r|r|}
\hline Biến độc lập & Hệ số hồi quy & \multicolumn{1}{|l|}{ Mức ý nghĩa } \\
\hline C & 1.82966 & 0.417 \\
\hline X6 & -2.63807 & 0.172 \\
\hline X7 & -4.38736 & 0.0006 \\
\hline X8 & -2.72846 & 0.0152 \\
\hline X9 & 0.145585 & 0.0211 \\
\hline X10 & -3.54272 & 0.0054 \\
\hline X11 & -2.53336 & 0.0477 \\
\hline X12 & -0.1048 & 0.3398 \\
\hline X13 & 1.147696 & 0.0179 \\
\hline X14 & -0.58686 & 0.0328 \\
\hline X16 & 0.4038 & 0.2985 \\
\hline X17 & -3.27297 & 0.0052 \\
\hline X18 & -0.97915 & 0.003 \\
\hline X19 & 1.328388 & 0.0054 \\
\hline
\end{tabular}

Nguồn: Nghiên cúu của tác giả

Từ kết quả chạy mô hình, ta thấy giá trị xác suất của X12 $=0.3398>\alpha=5 \%$ chứng tỏ hệ số của biến này có thể bằng 0 , ta sẽ tiến hành kiểm định để loại bỏ biến này ra khỏi mô hình.

Để kiểm tra xem có thể loại bỏ biến X12 ra khỏi mô hình không, ta tiến hành kiểm định Wald Test: 
Giả thiết:

Ho: $\mathrm{C}(12)=0$

H1: C(12)\#0

Kết quả kiểm định Wald Test:

Bảng 4.20 Kết quả kiểm định Wald Test để loại bỏ biến X12

\begin{tabular}{|c|c|c|c|}
\hline \multicolumn{4}{|l|}{ Wald Test: } \\
\hline \multicolumn{4}{|c|}{ Equation: Untitled } \\
\hline Test Statistic & Value & Df & Probability \\
\hline t-statistic & -0.946556 & 188 & 0.3451 \\
\hline F-statistic & 0.895967 & $(1,188)$ & 0.3451 \\
\hline Chi-square & 0.895967 & 1 & 0.3439 \\
\hline \multicolumn{4}{|c|}{ Null Hypothesis: $C(12)=0$} \\
\hline \multicolumn{4}{|c|}{ Null Hypothesis Summary: } \\
\hline \multicolumn{2}{|c|}{ Normalized Restriction $(=0)$} & Value & Std. Err. \\
\hline \multicolumn{2}{|l|}{$\mathrm{C}(12)$} & -0.11474 & 0.121219 \\
\hline
\end{tabular}

Nguồn: Nghiên cứu của tác giả

Kết quả kiểm định cho thấy, $C(12)=0$ kiểm định F-statistic có xác suất 0.3451 $>\alpha=5 \%$, và kiểm định Chi-square có xác suất $0.3439>\alpha=5 \%$, do đó ta chấp nhận giả thiết Ho, có thể bỏ biến X12 ra khỏi mô hình.

Sau khi loại bỏ biến 12 ra khỏi mô hình, ta tiến hành chạy lại mô hình với các biến còn lại 


\section{Bước 7: Chạy lại mô hình Logistic bỏ bớt biến X3, X4, X5, X2, X15, X12}

Chạy lại mô hình Logistic bỏ bớt biến X3, X4, X5, X2, X15, X12 ta có kết quả sau

Bảng 4.21 Kết quả hồi quy lần 7 sau khi bỏ bớt biến X3, X4, X5, X2, X15, X12

\begin{tabular}{|l|r|r|}
\hline Biến độc lập & Hệ số hồi quy & Mức ý nghĩa \\
\hline C & 1.488517 & 0.4944 \\
\hline X6 & -2.48658 & 0.1719 \\
\hline X7 & -4.46056 & 0.0005 \\
\hline X8 & -2.521 & 0.019 \\
\hline X9 & 0.152109 & 0.0187 \\
\hline X10 & -3.77423 & 0.0036 \\
\hline X11 & -3.29854 & 0.0036 \\
\hline X13 & 1.096872 & 0.0198 \\
\hline X14 & -0.64149 & 0.0234 \\
\hline X16 & 0.455309 & 0.2337 \\
\hline X17 & -3.35748 & 0.0056 \\
\hline X18 & -1.03974 & 0.0019 \\
\hline X19 & 1.432837 & 0.0029 \\
\hline
\end{tabular}

Nguồn: Nghiên cúu của tác giả

Từ kết quả chạy mô hình, ta thấy giá trị xác suất của X16=0.2337> $\alpha=5 \%$ chứng tỏ hệ số của biến này có thể bằng 0 , ta sẽ tiến hành kiểm định để loại bỏ biến này ra khỏi mô hình.

Để kiểm tra xem có thể loại bỏ biến X16 ra khỏi mô hình không, ta tiến hành kiểm định Wald Test: 
Giả thiết:

Ho: $\mathrm{C}(16)=0$

H1: C(16)\#0

Kết quả kiểm định Wald Test:

Bảng 4.22 Kết quả kiểm định Wald Test để loại bỏ biến X16

\begin{tabular}{|l|l|l|l|}
\hline \multicolumn{4}{|l|}{ Wald Test: } \\
\hline Equation: Untitled & Df & Probability \\
\hline Test Statistic & Value & 188 & 0.3721 \\
\hline t-statistic & 0.894665 & $(1,188)$ & 0.3721 \\
\hline F-statistic & 0.800426 & 1 & 0.3710 \\
\hline Chi-square & 0.800426 & Value & Std. Err. \\
\hline Null Hypothesis: C(16)=0 & 0.720568 & 0.805405 \\
\hline Null Hypothesis Summary: & Normalized Restriction (=0) & \\
\hline C(16) & Restrictions are linear in coefficients.
\end{tabular}

Nguồn: Nghiên cứu của tác giả

Kết quả kiểm định cho thấy, $\mathrm{C}(16)=0$ kiểm định F-statistic có xác suất 0.3721 $>\alpha=5 \%$, và kiểm định Chi-square có xác suất $0.3710>\alpha=5 \%$, do đó ta chấp nhận giả thiết Ho, có thể bỏ biến X16 ra khỏi mô hình.

Sau khi loại bỏ biến 16 ra khỏi mô hình, ta tiến hành chạy lại mô hình với các biến còn lại 


\section{Bước 8: Chạy lại mô hình Logistic bỏ bớt biến X3, X4, X5, X2, X15, X12, X16}

Chạy lại mô hình Logistic bỏ bớt biến X3, X4, X5, X2, X15, X12, X16 ta có kết quả sau:

Bảng 4.23 Kết quả hồi quy lần 8 sau khi bỏ bớt biến X3, X4, X5, X2, X15, X12, X16

\begin{tabular}{|l|r|r|}
\hline Biến độc lập & Hệ số hồi quy & Mức ý nghĩa \\
\hline C & 1.545319 & 0.4827 \\
\hline X6 & -2.34756 & 0.1696 \\
\hline X7 & -4.04128 & 0.0003 \\
\hline X8 & -2.42755 & 0.0215 \\
\hline X9 & 0.135481 & 0.0185 \\
\hline X10 & -3.37275 & 0.0026 \\
\hline X11 & -2.91293 & 0.0039 \\
\hline X13 & 1.049292 & 0.0192 \\
\hline X14 & -0.57061 & 0.0226 \\
\hline X17 & -2.91005 & 0.0053 \\
\hline X18 & -0.8757 & 0.0011 \\
\hline X19 & 1.348053 & 0.0023 \\
\hline
\end{tabular}

Nguồn: Nghiên cứu của tác giả

Từ kết quả chạy mô hình, ta thấy giá trị xác suất của X6=0.1696> $\alpha=5 \%$ chứng tỏ hệ số của biến này có thể bằng 0 , ta sẽ tiến hành kiểm định để loại bỏ biến này ra khỏi mô hình.

Để kiểm tra xem có thể loại bỏ biến X6 ra khỏi mô hình không, ta tiến hành kiểm định Wald Test: 
Giả thiết:

$$
\begin{aligned}
& \text { Ho: } \mathrm{C}(6)=0 \\
& \text { H1: C }(6) \# 0
\end{aligned}
$$

Kết quả kiểm định Wald Test:

\section{Bảng 4.24 Kết quả kiểm định Wald Test để loại bỏ biến X6}

\begin{tabular}{|l|l|l|l|}
\hline \multicolumn{4}{|l|}{ Wald Test: } \\
\hline Equation: Untitled & Value & Df & Probability \\
\hline Test Statistic & -1.111059 & 188 & 0.2680 \\
\hline t-statistic & 1.234453 & $(1,188)$ & 0.2680 \\
\hline F-statistic & 1.234453 & 1 & 0.2665 \\
\hline Chi-square & & \\
\hline Null Hypothesis: C(6)=0 & Value & Std. Err. \\
\hline Null Hypothesis Summary: & -1.9991 & 1.799271 \\
\hline Normalized Restriction $(=0)$ &
\end{tabular}

Nguồn: Nghiên cứu của tác giả

Kết quả kiểm định cho thấy, $C(6)=0$ kiểm định F-statistic có xác suất $0.2680>$ $\alpha=5 \%$, và kiểm định Chi-square có xác suất $0.2665>\alpha=5 \%$, do đó ta chấp nhận giả thiết Ho, có thể bỏ biến X6 ra khỏi mô hình.

Sau khi loại bỏ biến 6 ra khỏi mô hình, ta tiến hành chạy lại mô hình với các biến còn lại 
Bước 9: Chạy lại mô hình Logistic bỏ bớt biến X3, X4, X5, X2, X15, X12, X16, X6 Chạy lại mô hình Logistic bỏ bớt biến X3, X4, X5, X2, X15, X12, X16, X6 ta có kết quả sau:

Bảng 4.25 Kết quả hồi quy lần 9 sau khi bỏ bớt biến X3, X4, X5, X2, X15, X12, X16, X6

\begin{tabular}{|l|r|r|}
\hline Biến độc lập & Hệ số hồi quy & Mức ý nghĩa \\
\hline C & 2.470251 & 0.2408 \\
\hline X7 & -3.70193 & 0.0004 \\
\hline X8 & -2.28239 & 0.0247 \\
\hline X9 & 0.123035 & 0.0247 \\
\hline X10 & -3.40952 & 0.0019 \\
\hline X11 & -3.12182 & 0.002 \\
\hline X13 & 0.911514 & 0.0312 \\
\hline X14 & -0.57834 & 0.0183 \\
\hline X17 & -2.89896 & 0.0037 \\
\hline X18 & -0.91962 & 0.0007 \\
\hline X19 & 1.309259 & 0.0031 \\
\hline
\end{tabular}

Nguồn: Nghiên cứu của tác giả

Với mô hình đã loại bỏ các biến X3, X4, X5, X2, X15, X12, X16, X6, ta có kết quả nghiên cứu với 10 biến còn lại tất cả đều có ý nghĩa thống kê $\mathrm{P}$-value $<\alpha=5 \%$. Như vậy đây là mô hình tối ưu được lựa chọn

Mô hình được lựa chọn:

$\log _{e}\left[\frac{P(Y=0)}{P(Y=1)}\right]=2.47025144192-3.70192823429 * \mathrm{X} 7 \quad-2.28238602462 * \mathrm{X} 8+$ $0.123034531243 * \mathrm{X} 9-3.40951589375 * \mathrm{X} 10-3.12181523675 * \mathrm{X} 11+$ $0.911513951765 * \mathrm{X} 13-0.578343462832 * \mathrm{X} 14 \quad-2.89896310223 * \mathrm{X} 17 \quad-$ $0.919615474623 * X 18+1.30925946403 * X 19$ 


\subsubsection{Kết quả nghiên cứu đưa ra mô hình Binary Logistic}

Kết quả hồi quy từ mô hình nghiên cứu được thể hiện cụ thể qua bảng thống kê sau:

\section{Bảng 4.26 Tóm tắt kết quả mô hình nghiên cứu}

\begin{tabular}{|r|l|l|l|}
\hline STT & Biến độc lập & Diễn giải & Mức ý nghĩa \\
\hline 1 & $X 2$ & Số tiền vay & Không có ý nghĩa thống kê \\
\hline 2 & $X 3$ & Thời hạn vay & Không có ý nghĩa thống kê \\
\hline 4 & $X 5$ & Lãi suất & Không có ý nghĩa thống kê \\
\hline 5 & $X 6$ & Số tiền phải trả hàng tháng & Không có ý nghĩa thống kê \\
\hline 6 & $X 7$ & Trình độ học vấn & Không có ý nghĩa thống kê \\
\hline 7 & $X 8$ & Tình trạng hôn nhân & $5 \%$ \\
\hline 8 & $X 9$ & Giới tính & $5 \%$ \\
\hline 9 & $X 10$ & Tuổi & $5 \%$ \\
\hline 10 & $X 11$ & Nghề nghiệp & $5 \%$ \\
\hline 11 & $X 12$ & Tình trạng nhà ở & $5 \%$ \\
\hline 12 & $X 13$ & Thời gian sinh sống & Không có ý nghĩa thống kê \\
\hline 13 & $X 14$ & Số người phụ thuộc & \\
\hline 14 & $X 15$ & Thời gian công tác & $5 \%$ \\
\hline 15 & $X 16$ & Thu nhập cá nhân & Không có ý nghĩa thống kê \\
\hline 16 & $X 17$ & Chi phí cá nhân & Không có ý nghĩa thống kê \\
\hline 17 & $X 18$ & Bảo hiểm khoản vay & $5 \%$ \\
\hline 18 & $X 19$ & Thu nhập gia đình & $5 \%$ \\
\hline
\end{tabular}

Nguồn: Nghiên cứu của tác giả

Nhận xét: trong 18 biến được đưa vào mô hình, có $10 / 18$ biến giải thích được khả năng xảy ra rủi ro tín dụng khách hàng vay không có tài sản đảm bảo tại VPBank, đó là các biến về tình trạng hôn nhân (X7), giới tính (X8), tuổi (X9), nghề nghiệp (X10), tình trạng nhà ở (X11), số người phụ thuộc (X13), thời gian công tác (X14), bảo hiểm khoản vay (X17), thu nhập gia đình (X18), chi phí gia đình (X19).

8/10 biến còn lại không có ý nghĩa thống kê, nghĩa là không giải thích rõ được khả năng xảy ra rủi ro tín dụng khách hàng vay không có tài sản đảm bảo tại VPBank, đó là các biến: số tiền vay (X2), thời hạn vay (X3), lãi suất (X4), số tiền phải trả hang 
tháng (X5), trình độ học vấn (X6), thời gian sinh sống (X12), thu nhập cá nhân (X15), chi phí cá nhân (X16).

Từ đó, ta đưa ra được mô hình như sau:

$\log _{e}\left[\frac{P(Y=0)}{P(Y=1)}\right]=2.47025144192-3.70192823429 * \mathrm{X} 7-2.28238602462 * \mathrm{X} 8+$

$0.123034531243 * X 9-3.40951589375 * X 10-3.12181523675 * X 11+$

$0.911513951765 * X 13-0.578343462832 * X 14-2.89896310223 * X 17-$

$0.919615474623 * X 18+1.30925946403 * X 19$

Trong đó, mức ý nghĩa và hệ số hồi quy của từng biến độc lập được thể hiện cụ thể qua bảng sau:

Bảng 4.27 Tác động của từng biến độc lập trong mô hình đến rủi ro tín dụng

\begin{tabular}{|r|l|l|l|l|}
\hline STT & Biến độc lập & Diễn giải & Hệ số hồi quy & Mức ý nghĩa \\
\hline 1 & $X 7$ & $\begin{array}{l}\text { Tình trạng hôn } \\
\text { nhân }\end{array}$ & -3.701928 & 0.0004 \\
\hline 2 & $X 8$ & Giới tính & -2.282386 & 0.0247 \\
\hline 3 & $X 9$ & Tuổi & 0.123035 & 0.0247 \\
\hline 4 & $X 10$ & Nghề nghiệp & -3.409516 & 0.0019 \\
\hline 5 & $X 11$ & Tình trạng nhà ở & -3.121815 & 0.002 \\
\hline 6 & $X 13$ & $\begin{array}{l}\text { Số người phụ } \\
\text { thuộc }\end{array}$ & 0.911514 & 0.0312 \\
\hline 7 & $X 14$ & $\begin{array}{l}\text { Thời gian công } \\
\text { tác }\end{array}$ & -0.578343 & 0.0183 \\
\hline 8 & $X 17$ & $\begin{array}{l}\text { Bảo hiểm khoản } \\
\text { vay }\end{array}$ & -2.898963 & 0.0037 \\
\hline 9 & $X 18$ & $\begin{array}{l}\text { Thu nhập gia } \\
\text { đình }\end{array}$ & -0.919615 & 0.0007 \\
\hline 10 & $X 19$ & Chi phí gia đình & 1.309259 & 0.0031 \\
\hline
\end{tabular}

Nguồn: Nghiên cứu của tác giả

Với mức ý nghĩa thống kê 5\%, các biến X7, X8, X9, X10, X11, X13, X14, X17, $\mathrm{X} 18, \mathrm{X} 19$ có khả năng giải thích tốt nhất khả năng xảy ra rủi ro tín dụng khách hàng cá nhân tại VPBank. Như vậy, ta kết luận khả năng xảy ra rủi ro tín dụng khách hàng 
cá nhân tại VPBank phụ thuộc vào các yếu tố: tình trạng hôn nhân, giới tính, tuổi, nghề nghiệp, tình trạng nhà ở, số người phụ thuộc, thời gian công tác, bảo hiểm khoản vay, thu nhập gia đình, chi phí gia đình.

\subsection{Kiểm định thống kê}

\subsubsection{Kiểm định độ phù hợp của mô hình}

Dựa theo kết quả sau khi chạy mô hình 10 biến như trên, ta có bảng kết quả sau:

\section{Bảng 4.28 Kết quả tổng quát của mô hình}

\begin{tabular}{|l|l|}
\hline McFaddenR-squared & 0.675078 \\
\hline LR statistic & 97.96578 \\
\hline Prob(LR statistic) & 0 \\
\hline
\end{tabular}

Nguồn: Nghiên cứu của tác giả

Ta thấy mô hình có Prob (LR statistic) $=0.000000<\alpha=5 \%$, như vậy mô hình có ý nghĩa với $\alpha=5 \%$

McFadden R-squared $=0.675078$ cho thấy độ phù hợp của mô hình là $67.5 \%$. Có nghĩa là mô hình giải thích được xấp xỉ 67.5\% ý nghĩa các biến. Hay $67.5 \%$ rủi ro tín dụng được giải thích bởi các nhân tố như tình trạng hôn nhân (X7), giới tính (X8), tuổi (X9), nghề nghiệp (X10), tình trạng nhà ở (X11), số người phụ thuộc (X13), thời gian công tác (X14), bảo hiểm khoản vay (X17), thu nhập gia đình (X18), chi phí gia đình (X19).

\subsubsection{Kiểm định ý nghĩa thống kê các hệ số}

Để kiểm định lại ý nghĩa thống kê của các biến X7, X8, X9, X10, X11, X13, $\mathrm{X} 14, \mathrm{X} 17, \mathrm{X} 18, \mathrm{X} 19$ ta sử dụng kiểm định Wald Test với giả thiết:

Ho: $\mathrm{C}(7)=\mathrm{C}(8)=\mathrm{C}(9)=\mathrm{C}(10)=\mathrm{C}(11)=\mathrm{C}(13)=\mathrm{C}(14)=\mathrm{C}(17)=\mathrm{C}(18)=\mathrm{C}(19)=0$

H1: $\quad \mathrm{C}(7)$ \# 0;C(8) \# 0; C(7) \# 0;C(9) \# 0; C(10) \# 0;C(11) \# 0; C(13) \# 0;C(14) \# 0; C(17) \# 0;C(18) \# 0; C(19) \# 0;

Nếu p-value $<\alpha=10 \%$ : Bác bỏ Ho, chấp nhận H1. 
Kết quả kiểm định

Bảng 4.29 Kết quả kiểm định Wald Test ý nghĩa các hệ số

\begin{tabular}{|c|c|c|c|}
\hline \multicolumn{4}{|l|}{ Wald Test: } \\
\hline \multicolumn{4}{|c|}{ Equation: Untitled } \\
\hline Test Statistic & Value & Df & Probability \\
\hline F-statistic & 1.664246 & $(10,188)$ & 0.0918 \\
\hline Chi-square & 16.64246 & 10 & 0.0827 \\
\hline \multicolumn{4}{|c|}{$\begin{array}{l}\text { Null Hypothesis: } C(7)=C(8)=C(9)=C(10)=C(11)=C(13)=C \\
\qquad(14)=C(17)=C(18)=C(19)=0\end{array}$} \\
\hline \multicolumn{4}{|c|}{ Null Hypothesis Summary: } \\
\hline $\begin{array}{l}\text { Normalized } \\
(=0)\end{array}$ & Restriction & Value & Std. Err. \\
\hline $\mathrm{C}(7)$ & & -4.45059 & 1.356286 \\
\hline $\mathrm{C}(8)$ & & -3.05278 & 1.232248 \\
\hline $\mathrm{C}(9)$ & & 0.156806 & 0.073214 \\
\hline $\mathrm{C}(10)$ & & -4.10772 & 1.495883 \\
\hline $\mathrm{C}(11)$ & & -2.33825 & 1.352319 \\
\hline $\mathrm{C}(13)$ & & 1.085612 & 0.504391 \\
\hline $\mathrm{C}(14)$ & & -0.48502 & 0.262354 \\
\hline $\mathrm{C}(17)$ & & -3.51445 & 1.380175 \\
\hline $\mathrm{C}(18)$ & & -0.93091 & 0.341943 \\
\hline $\mathrm{C}(19)$ & & 1.327270 & 0.507496 \\
\hline
\end{tabular}

Nguồn: Nghiên cứu của tác giả

Kết quả kiểm định cho thấy, $\mathrm{C}(7)=\mathrm{C}(8)=\mathrm{C}(9)=\mathrm{C}(10)=\mathrm{C}(11)=\mathrm{C}(13)=$ $\mathrm{C}(14)=\mathrm{C}(17)=\mathrm{C}(18)=\mathrm{C}(19)=0$ kiểm định F-statistic có xác suất $0.0981<\alpha=$ $10 \%$, và kiểm định Chi-square có xác suất $0.0827<\alpha=10 \%$, do đó ta bác bỏ giả thiết Ho, chấp nhận H1. Điều này có nghĩa các biến X7, X8, X9, X10, X11, X13, X14, X17, X18, X19 đều có ý nghĩa thống kê với mức $\alpha=10 \%$. 


\subsection{Thảo luận về các biến nghiên cứu theo kết quả đối chiếu với thực tế.}

Sau khi tiến hành các kiểm định phù hợp, ta có thể kết luận mô hình các nhân tố ảnh hưởng đến rủi ro tín dụng khách hàng cá nhân vay không có tài sản đảm bảo tại VPBank như sau:

$$
\begin{aligned}
& \log _{e}\left[\frac{P(Y=0)}{P(Y=1)}\right]=2.47025144192-3.70192823429 * \mathrm{X} 7 \quad-2.28238602462 * \mathrm{X} 8+ \\
& 0.123034531243 * \mathrm{X} 9-3.40951589375 * \mathrm{X} 10-3.12181523675 * \mathrm{X} 11+ \\
& 0.911513951765 * X 13 \quad-0.578343462832 * X 14 \quad-\quad 2.89896310223 * X 17 \quad- \\
& 0.919615474623 * X 18+1.30925946403 * X 19
\end{aligned}
$$

Với quy ước xác suất

$\mathrm{P}(\mathrm{y})>50 \%$ : khách hàng có rủi ro tín dụng

$\mathrm{P}(\mathrm{y})<50 \%$ : khách hàng không có rủi ro tín dụng

Đối chiếu với kết quả thực tế 207 khách hàng được chọn mẫu, mô hình đã dự đoán chính xác được 180 trường hợp, dự đoán sai 27 trường hợp, tỷ lệ dự đoán chính xác là $86.95 \%$.

Như vậy, rủi ro tín dụng được giải thích bởi các nhân tố như tình trạng hôn nhân (X7), giới tính (X8), tuổi (X9), nghề nghiệp (X10), tình trạng nhà ở (X11), số người phụ thuộc (X13), thời gian công tác (X14), bảo hiểm khoản vay (X17), thu nhập gia đình (X18), chi phí gia đình (X19).

Trong mô hình, ta thấy hệ số X7 mang dấu “_-“ nghĩa là những khách hàng đã lập gia đình, có xu hướng trả nợ tốt hơn các khách hàng độc thân. Điều này có thể hiểu rằng những người đã lập gia đình, cuộc sống sẽ ổn định hơn, và có ý thức trách nhiệm hơn với khoản vay của mình.

Hệ số X8 mang dấu “-_“ thể hiện khách hàng là nam có xu hướng trả nợ tốt hơn khách hàng nữ, đúng như theo nghiên cứu của Lea (1995) và Xiao (1995).

Hệ số X9 mang dấu “+“" nghĩa là khách hàng càng lớn tuổi thì khả năng trả nợ càng thấp hơn so với các khách hàng trẻ tuổi, điều này đúng như kết quả nghiên cứu của Adcock và ctg (1977).

Hệ số X10 mang dấu “_“ thể hiện các khách hàng làm việc tại các công ty, xí nghiệp, tổ chức có lương ổn định thì sẽ trả nợ tốt hơn các khách hàng tự doanh, buôn bán nhỏ hoặc lao động tự do. 
Hệ số X11 mang dấu “_“" thể hiện các khách hàng có nhà riêng thường trả nợ tốt hơn những khách hàng ở nhà thuê, do cuộc sống sẽ ổn định hơn, không mất tiền thuê nhà hàng tháng, và ý thức trả nợ cũng tốt hơn, khó có thể bán nhà chuyển đi nơi khác hơn so với người thuê nhà.

Hệ số X13 mang dấu “+” đúng như kỳ vọng, những khách hàng có nhiều người phụ thuộc thì khả năng xảy ra rủi ro tín dụng cao hơn so với những khách hàng không có, hoặc có ít người phụ thuộc. Cụ thể, nếu khách hàng có thêm 1 người phụ thuộc, thì $\log$ của xác suất khả xảy ra rủi ro tín dụng sẽ tăng 0.911 đơn vị (lần).

Hệ số X14 mang dấu “-” đúng như kỳ vọng, những khách hàng có thời gian công tác, làm việc lâu năm, thường có thu nhập ổn định, có kinh nghiệm và uy tín thường trả nợ tốt hơn các khách hàng có thời gian công tác ngắn. Cụ thể nếu khách hàng có thêm 1 năm kinh nghiệm công tác thì thì log của xác suất khả năng khách hàng trả nợ tốt sẽ giảm 0.578 đơn vị (lần).

Hệ số X17 mang dấu ““_“ cho thấy các khách hàng có mua bảo hiểm khoản vay thường trả nợ tốt hơn các khách hàng không mua bảo hiểm khoản vay. Tại VPBank hiện nay, hình thức mua bảo hiểm khoản vay thường được khuyến khích nhưng không bắt buộc, như vậy, những khách hàng nào tự tham gia bảo hiểm khoản vay tự nguyện thể hiện ý thức trả nợ tốt, có trách nhiệm với khoản vay của mình.

Hệ số X18 mang dấu “-” và X19 mang dấu “+” thể hiện thu nhập của gia đình càng lớn, chi phí càng nhỏ thì rủi ro tín dụng càng thấp và ngược lại. Trong mô hình này, 2 biến thu nhập và chi phí cá nhân bị loại vì không có ý nghĩa thống kê, ta có thể hiểu vì 2 biến này đã bao hàm trong thu nhập và chi phí gia đình. Điều này mang rõ đặc tính của người Việt, sinh sống và chi tiêu gắn liền với gia đình rất chặt chẽ, do đó rủi ro tín dụng của một khách hàng cũng chịu ảnh hưởng từ thu nhập và chi phí của gia đình.

Hệ số $\beta 1=2.47$ tương đối cao, cho thấy sau khi bỏ qua các yếu tố tình trạng hôn nhân (X7), giới tính (X8), tuổi (X9), nghề nghiệp (X10), tình trạng nhà ở (X11), số người phụ thuộc (X13), thời gian công tác (X14), bảo hiểm khoản vay (X17), thu nhập gia đình (X18), chi phí gia đình (X19) thì bản thân mỗi khách hàng cũng có một mức rủi ro nhất định. 
Đối với những biến mô tả đặc điểm khoản vay đã không có ý nghĩa trong mô hình bao gồm số tiền vay (X2), lãi suất (X4), thời hạn vay (X3), số tiền trả hàng tháng (X5), không có ảnh hưởng đến mức độ rủi ro tín dụng, điều này có thể hiểu rằng các sản phầm cho vay cá nhân không có tài sản đảm bảo tại VPBank đã được thiết kế, nghiên cứu kỹ càng, ổn định về các mặt, hoàn toàn phù hợp với điều kiện của từng khách hàng cụ thể, do đó bản thân sản phẩm vay không gây ảnh hưởng đến rủi ro tín dụng. Nhưng cũng có thể do số mẫu nghiên cứu chưa đủ lớn, nên các biến chưa thể hiện được ý nghĩa.

Biến thời gian sinh sống tại địa chỉ hiện tại (X12) không có ý nghĩa thống kê, điều này có thể giải thích rằng biến này đã được bao hàm trong biến tình trạng nhà ở, những khách hàng thuê nhà thường có thời hạn ngắn, còn những khách hàng có nhà riêng hoặc sống cùng người thân thì sẽ có thời gian sinh sống tại địa chỉ lâu hơn. Do đó những khách hàng thuê nhà thường có rủi ro tín dụng cao hơn các trường hợp còn lại, điều này cũng thể hiện rằng những khách hàng có thời gian sinh sống tại địa chỉ hiện tại ngắn thì nguy cơ xảy ra rủi ro tín dụng cao hơn.

Biến thu nhập cá nhân (X15) và chi phí cá nhân (X16) không có ý nghĩa thống kê có thể là do tác động của đa cộng tuyến nên bị loại khỏi mô hình. Cũng có thể giải thích rằng hai biến này đã bao hàm trong biến thu nhập và chi phí gia đình. Thứ nhất là do các khách hàng độc thân, sinh sống một mình thì VPBank sẽ ghi nhận thông tin thu nhập chi phí cá nhân đúng bằng thu nhập chi phí gia đình. Thứ hai những khách hàng sống cùng gia đình, do đặc điểm sinh sống của người Việt, luôn gắn kết chặt chẽ với gia đình, do đó thu nhập chi phí gia đình đã bao gồm cả thu nhập chi phí cá nhân. Do những nguyên nhân trên, nên hai biến này bị loại khỏi mô hình.

\section{Tóm lược chương 4}

Nội dung chính của chương 4 là xây dựng mô hình hồi quy Logistic để phân tích các yếu tố ảnh hưởng đến rủi ro tín dụng khách hàng cá nhân không có tài sản đảm bảo tại VPBank. Bên cạnh đó, nội dung chương 4 cũng tiến hành phân tích một cách khái quát về thực trạng rủi ro tín dụng khách hàng cá nhân không có tài sản đảm bảo tại VPBank. 
Từ kết quả nghiên cứu có được, sau khi tiến hành các kiểm định, ta thấy mô hình có tình khả dụng và độ phù hợp khá tốt trong việc ứng dụng vào thực tiễn để xác định khả năng xảy ra rủi ro tín dụng đối với từng khách hàng, từ đó giúp việc ra quyết định tín dụng chính xác hơn, nhanh chóng hơn. Thêm vào đó, việc xác định được các yếu tố ảnh hưởng đến rủi ro tín dụng khách hàng cá nhân không có tài sản đảm bảo tại VPBank còn góp phần cung cấp thêm một góc độ mới trong công tác quản trị rủi ro tín dụng tại VPBank.

Đây là những thông tin cần thiết cho công tác thẩm định và giám sát sau cho vay, cung cấp thông tin hữu ích cho các cán bộ liên quan và là cơ sở để hình thành chương 5. 


\section{CHUOONG 5 \\ KẾT LUẬN VÀ GỢI Ý GIẢI PHÁP}

\subsection{Kết luận}

Với mục tiêu trở thành một trong 5 ngân hàng TMCP hàng đầu Việt Nam và một trong 3 ngân hàng TMCP bán lẻ hàng đầu Việt Nam vào năm 2017, mảng cho vay khách hàng cá nhân đang được VPBank phát triển một cách mạnh mẽ. Song song với số lượng, thì chất lượng tín dụng là một yếu tố tiên quyết trong việc ngăn ngừa và giảm thiểu rủi ro của hoạt động kinh doanh ngân hàng.

Sau quá trình nghiên cứu các lý thuyết về rủi ro tín dụng và quá trình phân tích rủi ro tín dụng khách hàng cá nhân vay không có tài sản đảm bảo tại VPBank, bên cạnh việc hoàn thiện các chính sách, tác giả đã ứng dụng mô hình logistic để xây dựng mô hình xác định xác suất khả năng xảy ra rủi ro tín dụng khách hàng cá nhân vay không có tài sản đảm bảo tại VPBank.

Theo đó, rủi ro tín dụng khách hàng cá nhân vay không có tài sản đảm bảo tại VPBank chịu tác động của các yếu tố như tình trạng hôn nhân, giới tính, tuổi, nghề nghiệp, tình trạng nhà ở, số người phụ thuộc, thời gian công tác, bảo hiểm khoản vay, thu nhập gia đình, chi phí gia đình. Với mức độ chính xác của mô hình là $86.95 \%$, mô hình giải thích được xấp xỉ $67.5 \%$ ý nghĩa các biến.

Bên cạnh đó, thông qua việc phân tích rủi ro tín dụng khách hàng cá nhân vay không có tài sản đảm bảo tại VPBank qua các năm, ta cũng nhận thấy mức độ rủi ro đa phần xuất phát từ phía bản thân khách hàng, và bộ phận thẩm định là bộ phận đánh giá, xem xét và quyết định phê duyệt hay từ chối khoản vay. Mô hình đề xuất sẽ góp một phần giảm tải thời gian và áp lực cho bộ phận thẩm định.

Tuy nhiên, do thời gian nghiên cứu có hạn, dữ liệu chưa đầy đủ nên mô hình cũng còn nhiều điểm hạn chế cần phải tiếp tục nghiên cứu sâu hơn ở các đề tài sau, do đó ngoài việc ứng dụng mô hình, chúng ta cũng cần xem xét nhiều yếu tố và gợi ý những chính sách phù hợp và khả thi hơn. 


\subsection{Gọi ý giải pháp}

\subsubsection{Gọi ý chính sách chung}

\subsubsection{1 Đối với ngân hàng nhà nước}

Để hoạt động tín dụng khách hàng cá nhân nói riêng và tín dụng ngân hàng nói chung hoạt động có hiệu quả hơn, giảm thiểu rủi ro tín dụng cho các ngân hàng, ngân hàng nhà nước nên hoàn thiện hơn về hệ thống pháp lý, các quy định liên quan đến tín dụng. Ngân hàng nhà nước nên có các quy định cụ thể về việc áp dụng các mô hình định lượng trong việc ra quyết định tín dụng, đối với từng đối tượng khách hàng nào, hình thức tín dụng nào thì áp dụng mô hình định lượng nào, điều này có thể góp phần nâng cao chất lượng tín dụng, giảm tỷ lệ nợ xấu của ngành ngân hàng.

Bên cạnh đó, cần phải có biện pháp công khai, minh bạch thông tin tín dụng của tất cả các khách hàng bao gồm cả thể nhân và pháp nhân. Hiện nay tại Việt Nam, hầu như tất cả các ngân hàng đều sử dụng thông tin tín dụng của khách hàng từ trung tâm thông tin tín dụng CIC. Tuy nhiên thông tin trên trang CIC công bố còn cập nhật tương đối chậm, thông thường từ 1 đến 3 tháng mới được cập nhật một lần, sự chậm trể này dễ dẫn đến việc ra quyết định tín dụng không chính xác, nguy cơ xảy ra rủi ro cao.

\subsubsection{2 Đối với mảng tín dụng cá nhân vay không có tài sản đảm bảo của VPBank}

\section{Gợi ý chính sách đối với bộ phận bán hàng}

Từ việc phân tích nguyên nhân xảy ra rủi ro tín dụng, ta thấy phần lớn xuất phát từ bản thân khách hàng, một phần từ ý thức, thái độ của khách hàng trong việc thanh toán nợ, một phần từ tình hình tài chính của khách hàng. Trong suốt quá trình tín dụng, bộ phận bán hàng là bộ phận đầu tiên tiếp xúc, tư vấn và làm hồ sơ cho khách hàng. Bộ phận này được tách riêng khỏi bộ phận phê duyệt tín dụng để tránh xảy ra tiêu cực, tuy nhiên bộ phận bán hàng cũng chịu chỉ tiêu, áp lực doanh số, nên việc chạy theo số lượng mà không quan tâm đến chất lượng là điều không thể tránh khỏi.

Do đó, để giảm thiểu rủi ro tín dụng, ngoài việc chạy theo doanh số, bộ phận bán hàng nên có thêm quy định phải chịu trách nhiệm một phần với rủi ro tín dụng trong quá trình khách hàng thanh toán. 
Bộ phận bán hàng nên tham khảo kết quả nghiên cứu của luận văn về các yếu tố ảnh hưởng đến rủi ro tín dụng khách hàng cá nhân như: tình trạng hôn nhân, giới tính, tuổi, nghề nghiệp, tình trạng nhà ở, số người phụ thuộc, thời gian công tác... Từ đó, bước đầu lựa chọn được những khách hàng có khả năng xảy ra rủi ro tín dụng thấp. Đối với những khách hàng có nguy cơ cao, thì nên cân nhắc lựa chọn tư vấn những sản phẩm an toàn hơn, yêu cầu cao hơn và hạn mức tín dụng thấp hơn.

Bên cạnh đó, bộ phận bán hàng phải được giám sát chặt chẽ quá trình tư vấn cho khách hàng. Để khách hàng đồng ý vay, đôi khi bộ phận bán hàng bỏ qua một vài yếu tố quan trọng nhưng không tư vấn cho khách hàng, hoặc tư vấn không rõ ràng ví dụ như điều khoản phí phạt trễ hạn, phí bảo hiểm khoản vay... điều này không những làm ảnh hưởng rất lớn đến uy tín của ngân hàng mà còn làm tăng nguy cơ rủi ro tín dụng.

\section{> Gợi ý chính sách đối với bộ phận phê duyệt tín dụng}

Với quy trình tín dụng hiện nay tại VPBank, chủ yếu là thu thập thông tin từ tài liệu khách hàng cung cấp và xác minh của bộ phận thẩm định. Tuy nhiên có một vài yếu tố dựa vào để ra quyết định tín dụng còn chưa phù hợp, cần phải được điều chỉnh theo những gợi ý như sau:

Yếu tố đánh giá tư cách khách hàng từ người thân, bạn bè, đồng nghiệp: đây là yếu tố rất khó xác định được một cách chính xác. Theo như quy trình, thì cán bộ thẩm định qua điện thoại và thẩm định tại nhà sẽ tiếp xúc, xác minh thông tin khách hàng từ phía người thân, bạn bè, đồng nghiệp. Trong số đó, sẽ có những người có quan hệ tốt, yêu mến khách hàng, tuy nhiên cũng không loại trừ trường hợp cán bộ tín dụng gặp phải đối tượng đồng nghiệp, hàng xóm cung cấp thông tin xấu về khách hàng một cách không khách quan vì những lý do cá nhân, không trung thực. Trong trường hợp này, nếu cán bộ tín dụng không xem xét tất cả các ý kiến một cách tổng quát sẽ rất dễ mắc phải rủi ro tín dụng khi từ chối khách hàng tốt. Do đó, khâu thẩm định qua điện thoại, phải tiến hành xác minh tất cả các thông tin khách hàng từ tất cả người tham chiếu có được, phải có cái nhìn tổng quát, không dựa vào ý kiến của một các nhân nào để ra quyết định tín dụng. Đối với những thông tin chưa chắc chắn, cần ghi chú lại nhờ bộ phận thẩm định tại nhà kiểm tra lại. 
Yếu tố đánh giá nhà cửa/ nơi làm việc của khách hàng: đây cũng là một yếu tố khó xác định và không có một chuẩn mực cụ thể để đo lường mức độ sơ sài nhà cửa hoặc nơi làm việc rất nhỏ. Nhưng đây lại là yếu tố chiếm một phần lớn nguyên nhân khiến khách hàng bị từ chối tín dụng từ bộ phận thẩm định hiện trường. Yếu tố này phụ thuộc rất nhiều vào tính chủ quan của cán bộ thẩm định. Đặc biệt nước ta lại có điều kiện kinh tế địa lý vùng miền rất đặc trưng, nếu như ở thành phố nhà cửa được đánh giá chủ yếu dựa vào căn nhà, thì ở vùng nông thôn nhà có thể đơn sơ nhưng còn nhiều yếu tố liên quan khác như ruộng, vườn, đồng, ao... Không thể áp dụng một chuẩn mực chung nhất vào đánh giá, và bị chi phối rất nhiều từ khả năng đánh giá nhận xét của cán bộ thẩm định. Do đó, việc xem xét đánh giá tình trạng nhà ở, nơi làm việc của khách hàng phải dựa vào điều kiện cụ thể của từng vùng miền địa phương và phải có cái nhìn đa dạng, không thể cứng nhắc trong công tác thẩm định.

Yếu tố xác định khách hàng làm giấy tờ giả: đây cũng là một yếu tố dựa vào trình độ và kinh nghiệm chủ quan của cán bộ tín dụng, chưa có tính chuyên nghiệp trong nghiệp vụ phát hiện giấy tờ giả. Mặc dù hiện nay tại VPBank có riêng một bộ phận an ninh, được đào tạo chuyên nghiệp để phát hiện gian lận, tuy nhiên chỉ những trường hợp nghi ngờ làm giả giấy tờ có tổ chức, có quy mô lớn và có dấu hiệu lừa đảo chiếm đoạt tài sản thì cán bộ tín dụng mới chuyển về bộ phận an ninh để điều tra. Còn lại, đa số những trường hợp nghi ngờ cá nhân khách hàng làm giả giấy tờ sẽ bị từ chối tín dụng. Điều này có nguy cơ làm tăng rủi ro từ chối nhầm khách hàng tốt, vì toàn bộ hồ sơ nộp về ngân hàng là bản photo, có chữ ký đối chiếu của nhân viên bán hàng, trong quá trình photo có thể có những lỗi kỹ thuật, hoặc bản thân giấy tờ gốc có những sai sót nhưng không được khách hàng phát hiện để điều chỉnh, hoặc có thể bản thân nhân viên bán hàng tự ý chỉnh sửa hồ sơ để khách hàng dễ được duyệt. Đo đó, đối với các giấy tờ nghi ngờ khách hàng cung cấp giấy tờ giả, nên giảm thiểu tỷ lệ từ chối trong trường này, thay vào đó cán bộ thẩm định ghi chú cho bộ phận thẩm định tại nhà đối chiếu giấy tờ gốc, nếu thật sự có dấu hiệu lừa đảo thì chuyển hồ sơ về bộ phận an ninh.

Quy trình thẩm định đến phê duyệt tín dụng hiện nay từ khoảng 3-5 ngày đối với một khách hàng có hồ sơ tốt, đối với những khách hàng thiếu chứng từ, phải bổ sung nhiều lần, thời gian phê duyệt sẽ kéo dài đến 10 ngày hoặc hơn. Điều này ảnh 
hưởng nhiều đến khách hàng cũng như uy tín của ngân hàng. Do đó, trong khâu thẩm định giấy tờ phải có tính nhất quán với tất cả các cán bộ thẩm định. Một hồ sơ phải được kiểm tra tất cả các giấy tờ trước khi quyết định trả về cho khách hàng bổ sung, tránh tình trạng sau khi cán bộ $\mathrm{A}$ trả về yêu cầu bổ sung giấy tờ, sau khi khách hàng nộp lại, cán bộ $\mathrm{B}$ tiếp nhận lại yêu cầu bổ sung giấy tờ khác.

Để khắc phục được tình trạng thông tin trên CIC cập nhật chậm, nên tiến hành kiểm tra thông tin CIC một lần tại bước thẩm định giấy tờ, và một lần nữa tại bước phê duyệt tín dụng trước khi ra quyết định để tránh rủi ro.

Thường xuyên tổ chức các buổi trang bị kiến thức, kỹ năng bổ sung cho các cán bộ tín dụng, liên tục cập nhật những thông tin mới nhất để quá trình ra quyết định tín dụng luôn đạt độ chính xác cao.

Song song với việc xem xét các yếu tố như quy trình thông thường, cán bộ tín dụng nên đặc biệt lưu ý thêm về các yếu tố ảnh hưởng đến rủi ro tín dụng từ kết quả nghiên cứu của luận văn bao gồm: tình trạng hôn nhân, giới tính, tuổi, nghề nghiệp, tình trạng nhà ở, số người phụ thuộc, thời gian công tác, bảo hiểm khoản vay, thu nhập và chi phí gia đình. Nếu khách hàng được vay nhưng các yếu tố nói trên có nhiều dấu hiệu rủi ro thì cán bộ nên xem xét kỹ hơn, điều chỉnh hạn mức tín dụng phù hợp hơn.

Bên cạnh những xem xét đánh giá mang tính chủ quan của cán bộ tín dụng, bộ phận phê duyệt tín dụng cần có một mô hình định tính, giúp cán bộ phê duyệt tín dụng có thêm một công cụ tính toán nhanh khả năng xảy ra rủi ro tín dụng của một khách hàng, từ đó góp phần tăng tính chính xác cho quyết định tín dụng.

\section{> Gợi ý chính sách đối với bộ phận giám sát sau cho vay và thu hồi nợ}

Việc xác định tỷ lệ nợ xấu cũng bị ảnh hưởng một phần bởi cách thức phân loại nhóm nợ dẫn đến tỷ lệ tăng lên so với thực tế. Hiện nay, việc phân loại nhóm nợ hoàn toàn dựa vào phương pháp định lượng.

Thực tế có rất nhiều trường hợp không thể dựa vào số ngày khách hàng thanh toán chậm để chuyển nhóm nợ. Vì hiện tại, VPBank xác định ngày trả tiền hàng tháng dựa vào ngày khách hàng giải ngân chứ không dựa vào ngày khách hàng nhận lương. Như vậy sẽ có nhiều trường hợp khách hàng hoàn toàn có khả năng thanh toán, nhưng sẽ 
chậm hơn so với lịch thanh toán, điều này có thể dẫn đến việc khách hàng bị chuyển nợ nhóm 2 không chính xác.

Song song với việc chuyển nhóm nợ không chính xác, thì quy trình xử lý sau khi chuyển nhóm nợ cũng sẽ thay đổi, từ đó nhiều trường hợp dẫn đến khách hàng hoàn toàn có khả năng thanh toán nhưng vì khó chịu vì quy trình xử lý nợ như bị gọi điện nhiều lần, người thân bị làm phiền... nên quyết định thanh lý hợp đồng, dẫn đến tổn thất từ phía ngân hàng.

Do đó, quy trình giám sát sau cho vay và thu hồi nợ cần phải linh hoạt hơn, không cứng nhắc trong một quy trình nhất định áp dụng cho tất cả các khách hàng.

Đối với các khách hàng có lịch sử thanh toán tốt, điều kiện gia đình và công việc ổn định, thì quy giám sát sau cho vay nên nới lỏng hơn, tránh tình trạng tạo cảm giác khó chịu, bị làm phiền cho khách hàng và người thân, tránh tối thiểu tình trạng khách hàng tốt lại thanh lý hợp đồng vì không chấp nhận quy trình thủ tục rườm rà.

Đối với các khách hàng có tình hình tài chính tốt, nhưng ngày lãnh lương bị trễ hơn so với ngày đóng tiền hàng tháng, nên tránh gọi điện nhắc nợ thường xuyên, tìm hiểu rõ nguyên nhân khách hàng chưa thanh toán, nếu thật sự đúng do nguyên nhân khách quan thì chuyển các phòng ban hỗ trợ thay đổi lịch thanh toán hàng tháng cho khách hàng.

Đối với những khách hàng cố ý né tránh, không thanh toán, phải cố gắng tìm hiểu nguyên nhân, đàm phán và thuyết phục, cố gắng giảm tỷ lệ nợ chuyển qua bộ phận pháp lý.

Bên cạnh việc xử lý khách hàng dựa trên nhóm nợ, bộ phận thu hồi nợ nên cân nhắc tham khảo thêm kết quả nghiên cứu của đề tài về các yếu tố ảnh hưởng đến rủi ro tín dụng như: tình trạng hôn nhân, giới tính, tuổi, nghề nghiệp, tình trạng nhà ở, số người phụ thuộc, thời gian công tác, bảo hiểm khoản vay, thu nhập và chi phí gia đình. Theo đó, nếu những khách hàng đang trả nợ tốt, nhưng các yếu tố trên có nhiều dấu hiệu rủi ro thì bộ phận thu hồi nợ nên tăng cường giám sát chặt chẽ hơn để tránh xảy ra rủi ro. 


\subsubsection{Gợi ý áp dụng Mô hình logistic trong việc xác định xác suất rủi ro tín dụng khách hàng cá nhân vay không có tài sản đảm bảo tại VPBank}

Sau quá trình nghiên cứu, ngoài những gợi ý chính sách chung cho các bộ phận để tham khải góp phần giảm thiểu rủi ro tín dụng cá nhân vay không có tài sản đảm bảo tại VPBank, tác giả cũng đề xuất áp dụng mô hình Logistic để xác định xác suất rủi ro như trên:

$$
\begin{aligned}
& \log _{e}\left[\frac{P(Y=0)}{P(Y=1)}\right]=2.47025144192 \quad-3.70192823429 * \mathrm{X} 7 \quad-2.28238602462 * \mathrm{X} 8+ \\
& 0.123034531243 * X 9-3.40951589375 * \mathrm{X} 10-3.12181523675 * \mathrm{X} 11+ \\
& 0.911513951765 * \mathrm{X} 13-0.578343462832 * \mathrm{X} 14 \quad-\quad 2.89896310223 * \mathrm{X} 17 \quad- \\
& 0.919615474623 * \mathrm{X} 18+1.30925946403 * \mathrm{X} 19
\end{aligned}
$$

Theo đó, rủi ro tín dụng khách hàng cá nhân vay không có tài sản đảm bảo tại VPBank chịu tác động của các yếu tố như tình trạng hôn nhân, giới tính, tuổi, nghề nghiệp, tình trạng nhà ở, số người phụ thuộc, thời gian công tác, bảo hiểm khoản vay, thu nhập gia đình, chi phí gia đình. Mô hình sẽ góp thêm một công cụ giúp bộ phận phê duyệt tín dụng tính toán được xác suất khách hàng xảy ra rủi ro tín dụng với một mức độ chính xác nhất định. Từ đó sẽ góp phần giảm thiểu thời gian và áp lực cho bộ phận phê duyệt tín dụng.

Tuy nhiên, do thời gian nghiên cứu có hạn, mô hình cũng còn nhiều hạn chế và cần được nghiên cứu tiếp, nên mô hình chỉ mang tính chất tham khảo, góp thêm một công cụ trong quá trình phê duyệt tín dụng chứ không thể thay thế hoàn toàn phương pháp định tính truyền thống. Vì vậy, để đưa mô hình này vào thực tiễn hoạt động, VPBank còn cần phải xem xét đánh giá nhiều yếu tố khác nhau.

Một điều kiện khác để ứng dụng mô hình logistic trong việc xác định xác suất rủi ro tín dụng khách hàng cá nhân vay không có tài sản đảm bảo tại VPBank là phải thường theo dõi, đánh giá độ chính xác của mô hình để kịp thời điều chỉnh theo từng thời điểm, vì trong từng chu kỳ kinh tế khác nhau có thể đặc điểm của khách hàng cũng sẽ khác nhau. Mặt khác, chúng ta đang sử dụng dữ liệu của khách hàng trong quá khứ để xây dựng mô hình dự báo xác suất rủi ro cho khách hàng trong tương lai, nên không thể sử dụng một mô hình duy nhất trong suốt tất cả các năm. 


\subsection{Những hạn chế của đề tài và hướng nghiên cứu tiếp theo}

Mô hình logistic trong việc xác định xác suất rủi ro tín dụng khách hàng cá nhân vay không có tài sản đảm bảo tại VPBank thể hiện nhiều ưu điểm hơn so với quá trình đánh giá rủi ro định tính truyền thống:

- Mô hình trực tiếp đưa ra được xác suất rủi ro tín dụng nhanh chóng, góp phần giúp cán bộ tín dụng rút ngắn thời gian đưa ra quyết định tín dụng.

- Mô hình lượng hoá các biến định tính thành các biến định lượng dưới dạng câu hỏi có/không nên có thể giảm được tính chủ quan của cán bộ tín dụng.

- Số lượng biến đưa vào mô hình chỉ bao gồm 10 biến, và việc thu thập thông tin từ các biến này từ khách hàng khá đơn giản.

- Mô hình góp phần giảm bớt tính chủ quan của hình thức đánh giá định tính truyền thống, từ đó sẽ giảm được khả năng xảy ra rủi ro chủ quan.

Tuy nhiên, bên cạnh những ưu điểm, mô hình logistic trong việc xác định xác suất rủi ro tín dụng khách hàng cá nhân vay không có tài sản đảm bảo tại VPBank cũng thể hiện một vài hạn chế như sau:

- Về kích cỡ mẫu nghiên cứu: Do kích cỡ mẫu nhỏ (207 mẫu) nên việc ứng dụng mô hình logistic trong việc xác định xác suất rủi ro tín dụng khách hàng cá nhân vay không có tài sản đảm bảo tại VPBank còn nhiều hạn chế, chưa thể khẳng định hoàn toàn tính chính xác của mô hình. Để ứng dụng mô hình vào thực tiển hoạt động, cần tiến hành nghiên cứu lại trên phạm vi rộng hơn, tăng kích cỡ mẫu để tăng tính chính xác cho mô hình

- Về mức độ phù hợp của mô hình: McFadden R-squared $=0.675078$ cho thấy độ phù hợp của mô hình là $67.5 \%$, hay mô hình giải thích được xấp xỉ 67.5\% ý nghĩa các biến. Điều này có nghĩa là, có thể còn có các biến khác có ý nghĩa nhưng chưa được đưa vào mô hình. Để tăng tính phù hợp cho mô hình, ta cần tiến hành kiểm định biến bị bỏ sót trong mô hình và nghiên cứu đưa thêm biến vào để tăng độ phù hợp.

- Về tính ứng dụng của mô hình: các biến trong mô hình được lựa chọn khá đơn giản, tuy nhiên để có được kết quả chính xác để đưa vào mô hình, chúng ta vẫn cần đến quy trình thẩm định truyền thống, ví dụ như để tính toán chính xác các khoản thu nhập, chi phí từ tài liệu và thông tin mà khách hàng cung cấp, hoặc 
xác minh chính xác thời gian công tác, số người phụ thuộc từ hồ sơ của khách hàng.

Với những hạn chế vừa nêu, để hoàn thiện hơn về mô hình logistic trong việc xác định xác suất rủi ro tín dụng khách hàng cá nhân vay không có tài sản đảm bảo tại VPBank, tác giả đề xuất hướng nghiên cứu tiếp theo như sau:

- Mở rộng phạm vi nghiên cứu, tăng kích cỡ mẫu, đặc biệt là tăng tỷ lệ mẫu nhóm 1 - nhóm có rủi ro tín dụng để có được kết quả nghiên cứu tổng quát hơn, chính xác hơn.

- Tiến hành kiểm định các biến bị bỏ xót trong mô hình, nghiên cứu đưa thêm biến mới vào mô hình để tăng mức độ phù hợp.

Ví dụ như theo nghiên cứu của Vương Quân Hoàng thì giá trị tài sản của khách hàng và giá trị các khoản nợ có ảnh hưởng đến tỷ lệ rủi ro tín dụng. Tuy nhiên với đối tượng khách hàng cá nhân vay không có tài sản đảm bảo tại VPBank hiện nay thì VPBank chưa có yêu cầu thông tin này, nên chưa có dữ liệu để thống kê đưa vào nghiên cứu. Ở các nghiên cứu tiếp theo, tác giả sẽ hướng đến thu thập dữ liệu về 2 biến này để tiến hành kiểm định mức độ ảnh hưởng của các biến này đến rủi ro tính dụng.

Hoặc theo như các nghiên cứu trước, lịch sử tín dụng của khách hàng trong quá khứ cũng là một yếu tố ảnh hưởng đến rủi ro tín dụng, nhưng yếu tố này đã không được đưa vào trong nghiên cứu này. Nguyên nhân là do quy trình tín dụng hiện nay tại VPBank, sau khi kiểm tra thông tin trên CIC, nếu khách hàng đạt yêu cầu thì sẽ tiến hành các bước thẩm định tiếp theo và không lưu thông tin CIC lại trong hồ sơ khách hàng nên hiện tại không có dữ liệu để phục vụ nghiên cứu này. Ớ các nghiên cứu tiếp theo tác giả cũng sẽ hướng đến thu thập dữ liệu về biến này để tiến hành kiểm định mức độ ảnh hưởng của các biến này đến rủi ro tín dụng.

\section{Tóm lược chương 5}

Dựa trên kết quả mô hình nghiên cứu cũng như kết quả phân tích thực trạng rủi ro tín dụng, chương 5 đã đề xuất các nhóm giải pháp đối với từng bộ phận cụ thể nhằm 
góp phần hạn chế rủi ro tín dụng khách hàng cá nhân không có tài sản đảm bảo tại VPBank.

Bên cạnh đó, luận văn cũng đề xuất ứng dụng mô hình nghiên cứu vào thực tiễn hoạt động tại VPBank nhằm góp thêm một công cụ đo lường rủi ro tín dụng kết hợp với các phương pháp truyền thống để đạt được hiệu quả cao nhất.

Sau cùng, luận văn đưa ra những hạn chế của đề tài và hướng nghiên cứu tiếp theo cho các nghiên cứu sau này. 


\section{TÀI LIỆU THAM KHẢO}

\section{A. Tài liệu tiếng Việt}

1) Nguyễn Lê Ngọc Ca (2011) - Giải pháp phát triển tín dụng cá nhân tại ngân hàng TMCP Ngoại thuoong Việt Nam, ĐH Kinh tế TP HCM, Luận văn thạc sĩ.

2) Nguyễn Anh Dũng (2012) - Quản trị rủi ro tín dụng tại chi nhánh ngân hàng đầu tu và phát triển Bình Định, Đại học Đà Nẵng, Luận văn thạc sĩ.

3) Nguyễn Đăng Dờn (2011), Giáo trình tiền tệ - ngân hàng, NXB ĐH Quốc gia TPHCM

4) Nguyễn Đăng Dờn (2011), Quản trị ngân hàng thuơng mại hiện đại, NXB Phương Đông

5) Nguyễn Quang Đông, (2006) Giáo trình kinh tế lương, NXB Khoa học kỹ thuật

6) Nguyễn Phúc Thế Đức (2008) - Hoàn thiện hệ thống chấm diểm xếp loại khách hàng nhằm giảm thiểu rủi ro tín dụng tại ngân hàng đầu tu và phát triển Việt Nam, trường ĐH Kinh tế TP Hồ Chí Minh, Luận văn thạc sĩ.

7) Đoàn Thanh Hà (2012), Giáo trình Hoạt động cho vay của các Ngân hàng thuoong mai, Trường ĐH Ngân hàng TP HCM

8) Trần Thị Thuý Hà, (2012), Nghiên cứu về hệ thống xếp hạng tín dụng nội bộ của Ngân hàng TMCP Nhà Hà Nội, Luận văn thạc sĩ, Universite De Nantes

9) Vương Quân Hoàng, Đào Gia Hưng, Nguyễn Văn Hữu, Trần Minh Ngọc và Lê Hồng Phương (2006), Phương pháp thống kê xây dựng mô hình định mức tín nhiệm khách hàng thể nhân, Tạp chí ứng dụng toán học, tập 4, số 2, 2006

10) Nguyễn Minh Kiều (2013), Tín dụng và thẩm định tín dụng ngân hàng, NXB Tài chính

11)Trương Đông Lộc và Nguyễn Thị Tuyết (2011), Các nhân tố ảnh hưởng đến rủi ro tín dụng của ngân hàng thương mại cổ phần ngoại thương chi nhánh Cần Thơ, Tạp chí Ngân hàng, số 5, tháng 3, năm 2011, trang 38-41 
12)Lê Thị Minh Ngọc (2013). Úng dụng mô hình Logistic trong xếp hạng tín dụng khách hàng cá nhân tại ngân hàng thuơng mại cổ phần xuất nhập khẩu Việt Nam, Luận văn thạc sĩ kinh tế, Trường ĐH Kinh tế TP. HCM

13)Ngân hàng nhà nước Việt Nam, (2005), Quy định về phân loại nộ, trích lập và sử dụng dự phòng để xủ lý rủi ro, theo Quyết định số 493/2005/QĐ-NHNN ngày 22/4/2005 của Thống đốc NHNN

14) Ngân hàng TMCP VPBank (2011-2014), Báo cáo thuờng niên có kiểm toán, TP HCM

15) Vũ Việt Quảng (2013), Giáo trình Kinh tế lương trong tài chính, Trường ĐH Kinh tế TP HCM

16) Quốc hội khoá XII, Luật các tổ chức tín dụng, theo Thông tin văn bản số: 47/2010/QH12

17)Đỗ Thị Thu Quỳnh (2013), Một số giải pháp hạn chế rủi ro tín dụng tại Ngân hàng TMCP Công Thuoong Việt Nam - chi nhánh 1 TP HCM, Đại học kinh tế TP HCM, Luận văn thạc sĩ.

18)Trần Thị Thanh Thảo (2010), Giải pháp hạn chế rủi ro tín dụng tại chi nhánh ngân hàng thuoong mại cổ phần ngoại thuơng Đà Nã̃ng, Đại học Đà Nẵng, Luận văn thạc sĩ.

19) Nguyễn Văn Tiến (2014), Giáo trình tín dụng ngân hàng, NXB Thống Kê

20)Lê Văn Triết (2010). Hoàn thiện hệ thống xếp hạng tín dụng cá nhân của ngân hàng TMCP Á châu, luận án thạc sĩ kinh tế, trường ĐH Kinh tế TP.HCM

21)Hoàng Trọng \& Chu Nguyễn Mộng Ngọc, (2008), Thống kê ưng dụng, NXB Thống Kê

\section{B. Tài liệu tiếng Anh}

22) Adcock, W.O., Hirschman, E.C. and Goldstucker, J. C., (1977), Bank credit card users: an update profile Advances in Consumer Research, Vol. 4, pp.236 $-241$

23)Dinh Thi Huyen Thanh \& Stafanie Kleimeier, 2006. Credit Scoring forVietnam's Retail Banking Market 
24)Lea, S. E. G., Webley, P., and Walker, C. M., (1995), Psychological factors in consumer debt: Money management, economic socialization, and credit use, Journal of Economic Psychology, Vol.16, pp. 681-701;

25)Maddala, GS (1983), "Limited dependent and qualitative variables in econometrics”, Cambridge University Press.

26)Xiao, J. J., Noring, F. E., and Anderson, J. G., (1995), ollege studen' attitudes towards credit cards, Journal of Consumer Studies, Vol.19, pp. 155-174;

\section{Cổng thông tin điện tử}

27) Xuân Anh (2015), Mở rộng cho vay cá nhân, Tạp chí Sài Gòn đầu tư 1/6/2015 http://www.saigondautu.com.vn/Pages/20150530/Mo-rong-cho-vay-ca-nhan.aspx Truy xuất 15/6/2015

28) Phạm Thị Kim Ánh (2014), Nợ xấu ngân hàng và các vấn đề xử lý, Tạp chí khoa học trường ĐH Công nghiệp 2-2014

http://www.cntp.edu.vn/uploads/file/tap-chi-khoa-hoc/tap-chi-khcn-2-2014/noxau-nang-hang-va-cac-van-de-xu-ly.pdf Truy xuất 18/12/1014

29) Nguyễn Thị Mai Hoa (2011), Hạn chế rủi ro trong hoạt động cho vay của các NHTM, Tạp chí Nghiên cứu lập pháp số 201 - tháng 8/2011

http://www.fdvn.vn/index.php?option=com_content\&view=article \&id=1003\%3Ah n-ch-ri-ro-trong-hot-ng-cho-vay-ca-cac-ngan-hang-thng-mi\&catid=2\%3Ax-phucthm-v-tan-hoang-phat-khong-hy-an-la-sai\&Itemid=18\&lang=vi Truy xuất ngày $7 / 9 / 2014$

30)Nguyễn Anh Khoa (2014), Mô hình Logistic trong xếp hạng rủi ro tín dụng http://www.itgvietnam.com/mo-hinh-logistic-trong-xep-hang-rui-ro-tin-dung/ Truy xuất ngày 16/2/2015 